\title{
Platinum-Group Elements
}

Chapter $\mathrm{N}$ of

Critical Mineral Resources of the United States-Economic and Environmental Geology and Prospects for Future Supply

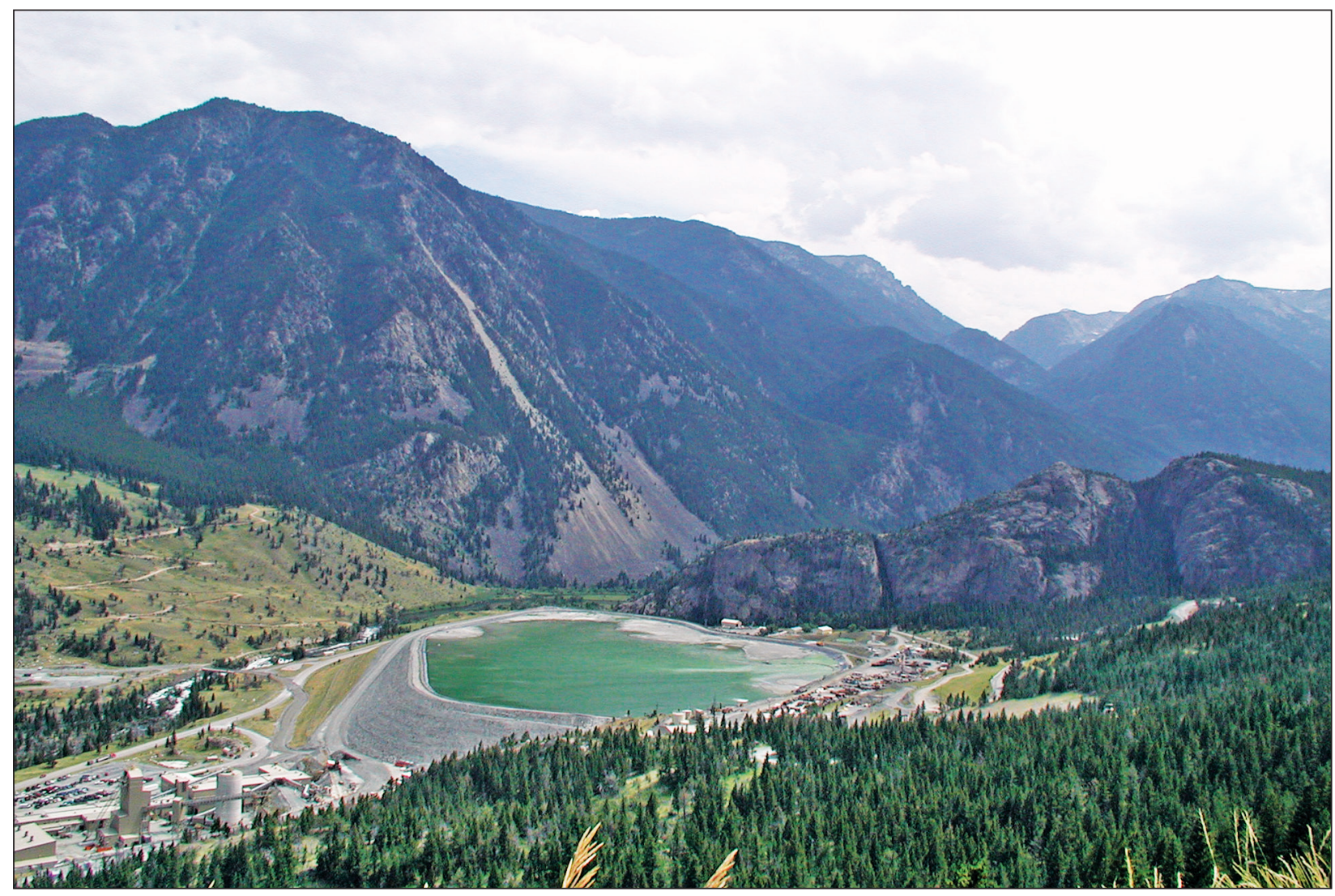

Professional Paper 1802-N 


\section{Periodic Table of Elements}

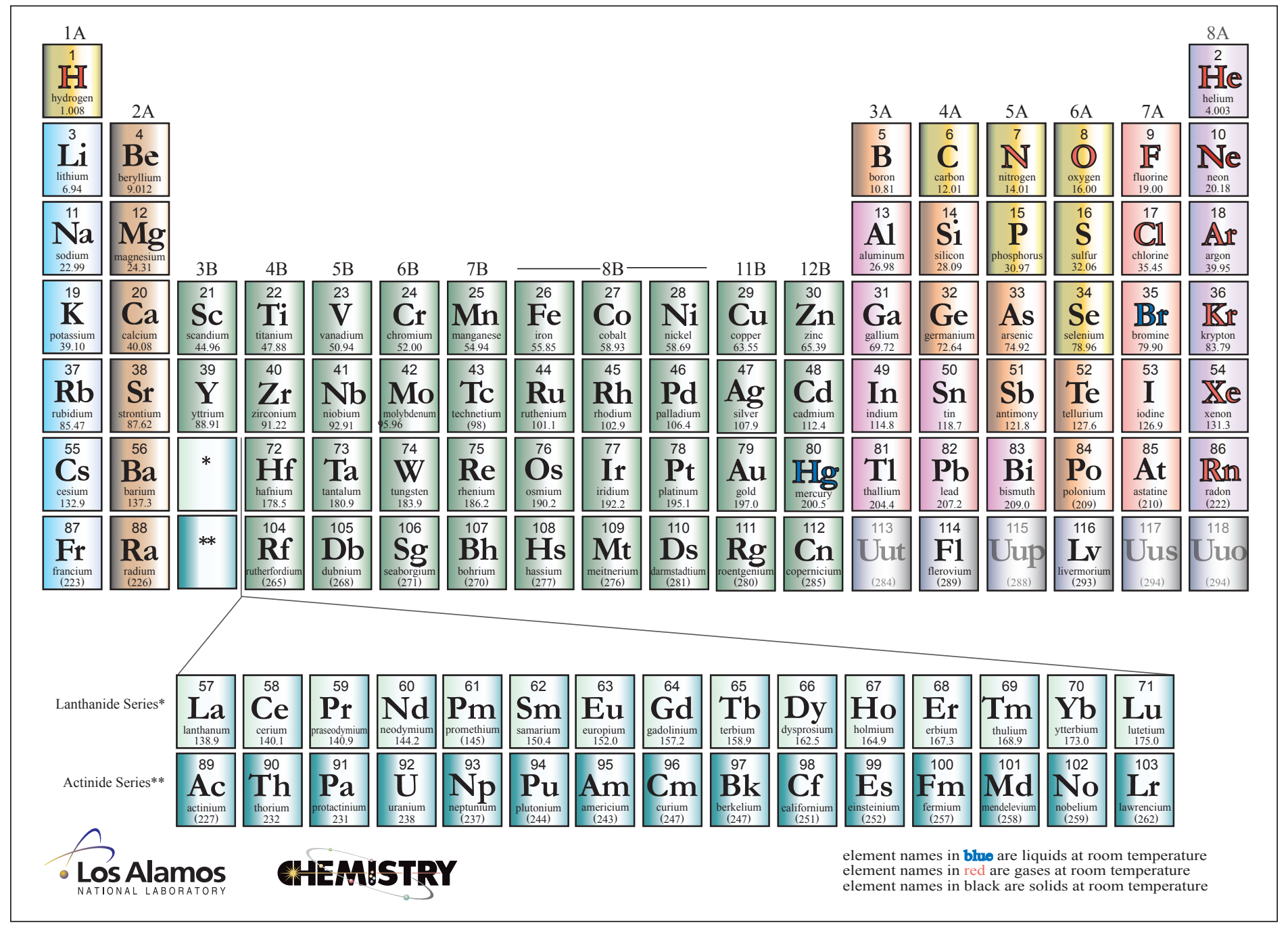

Modified from Los Alamos National Laboratory Chemistry Division; available at http://periodic.lanl.gov/images/periodictable.pdf.

Cover. Stillwater Mine in south-central Montana, looking southeast. The pond is the tailings impoundment. The buildings in the lower left include the shaft, the mill complex, and offices. Photograph by Michael L. Zientek, 2006. 


\section{Platinum-Group Elements}

By Michael L. Zientek, Patricia J. Loferski, Heather L. Parks, Ruth F. Schulte, and Robert R. Seal II

Chapter $\mathrm{N}$ of

Critical Mineral Resources of the United States-Economic and Environmental Geology and Prospects for Future Supply

Edited by Klaus J. Schulz, John H. DeYoung, Jr., Robert R. Seal II, and Dwight C. Bradley

Professional Paper 1802-N 


\title{
U.S. Department of the Interior RYAN K. ZINKE, Secretary
}

\section{U.S. Geological Survey William H. Werkheiser, Acting Director}

\author{
U.S. Geological Survey, Reston, Virginia: 2017
}

For more information on the USGS — the Federal source for science about the Earth, its natural and living resources, natural hazards, and the environment-visit https://www.usgs.gov or call 1-888-ASK-USGS.

For an overview of USGS information products, including maps, imagery, and publications, visit https://store.usgs.gov/.

Any use of trade, firm, or product names is for descriptive purposes only and does not imply endorsement by the U.S. Government.

Although this information product, for the most part, is in the public domain, it also may contain copyrighted materials as noted in the text. Permission to reproduce copyrighted items must be secured from the copyright owner.

Suggested citation:

Zientek, M.L., Loferski, P.J., Parks, H.L., Schulte, R.F., and Seal, R.R., II, 2017, Platinum-group elements, chap. N of Schulz, K.J., DeYoung, J.H., Jr., Seal, R.R., II, and Bradley, D.C., eds., Critical mineral resources of the United StatesEconomic and environmental geology and prospects for future supply: U.S. Geological Survey Professional Paper 1802, p. N1-N91, https://doi.org/10.3133/pp1802N.

ISSN 2330-7102 (online) 


\section{Contents}

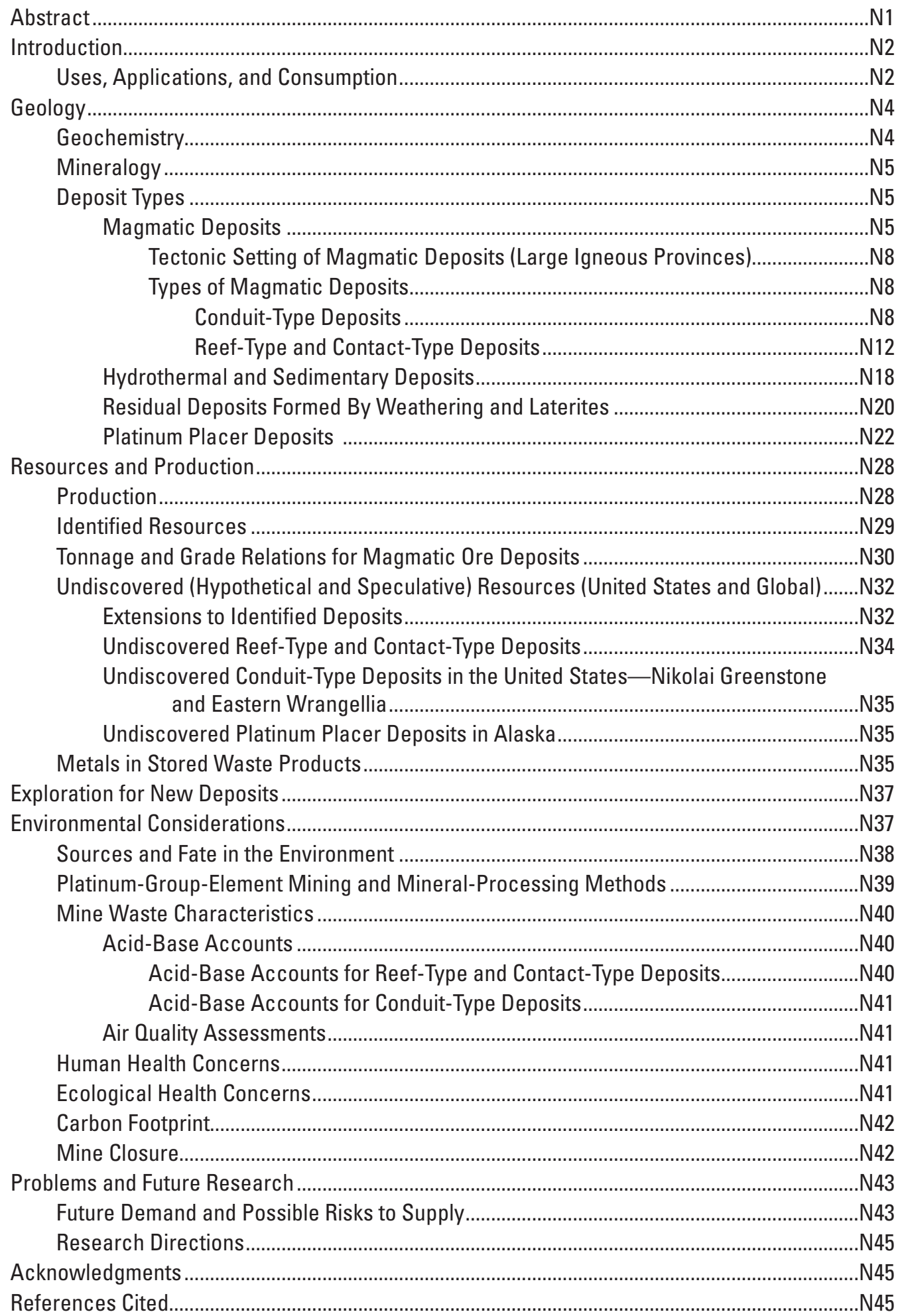




\section{Figures}

N1. Graphs showing platinum and palladium consumption, by category of use, from 2000 to 2012 for the world, North America, and China..

N2. Photograph of gold mask with platinum highlights, from the period of

La Tolita culture, Ecuador.

N3. World map showing locations of igneous intrusions and intrusive complexes that contain most of the world's platinum-group-element deposits, as well as the placer deposits that are mentioned in the text.

N4. Schematic block diagram showing changes in the form of igneous intrusions with depth and the relative occurrence of conduit-type, contact-type, and reef-type magmatic ore deposits

N5. Map showing the geology of the Siberian flood basalt province in Russia, which is the largest flood basalt province in the world.

N6. Map showing the geology of the Noril'sk-Talnakh area and the location of nickel-copper-platinum-group-element deposits

N7. Maps showing nickel-copper-platinum-group-element deposits in the Talnakh area, Russia

N8. Photograph of copper-rich massive sulfide ore exposed in a stope in the Oktyabr'sk Mine in the Talnakh area, Russia

N9. Map showing the Rustenburg Layered Suite of the Bushveld Complex, South Africa, the surface trace of significant orebodies, and cross sections through the central area and northeastern limb

N10. Photograph of the UG2 Chromitite at the Karee Mine in the western part of the Bushveld Complex, South Africa.

N11. Photograph of the base of the Merensky cyclic unit, a pegmatoidal pyroxenite, which contains the platinum-group-element-rich Merensky Reef

N12. Geologic map and cross sections of the Great Dyke, Zimbabwe N17

N13. Geologic map and cross section of the Stillwater Complex, Montana N19

N14. Photograph of the Stillwater Mine in south-central Montana, looking southeast.

N15. Map showing the geology along the western margin of the Duluth Complex, Minnesota, with the surface projection of nickel-copper-platinum-groupelement deposits and exploration targets

N16. Maps illustrating the distribution of platinum deposits in the Ural Mountains, Russia

N17. Geology and imagery of the Uralian-type Kondyor Massif, which is located in eastern Siberia, Russia, north of the city of Khabarovsk

N18. Photograph and lithograph showing the morphology of platinum-iron-alloy nuggets derived from Uralian-type intrusions

N19. Maps illustrating platinum-group-element resources in southeastern Alaska. .N27

N20. Graph showing world platinum-group-element production, by country and year, from 1960 to 2011.

N21. Pie chart showing world platinum-group-element production from 1960 to 2011, by country and amount, in metric tons...

N22. Plot showing the relation between tonnage and grade of remaining resources for conduit-type, reef-type, and other types of deposits enriched in platinumgroup elements 
N23. Graphs showing the percent of contained metal against percent of deposits for the world's platinum-group-element (PGE) and porphyry copper deposits and for the top 30 percent of the world's PGE deposits. N31

N24. Graph showing contained platinum-group-element (PGE) and gold metal against the ratio of palladium to platinum for the major PGE deposits of the world.

N25. Three-dimensional block diagram showing the Merensky Reef interpolated down to 2 kilometers in the southern area of the western limb of the Bushveld Complex, South Africa

N26. Graph illustrating the exposed area and stratigraphic thickness of cumulates in more than 200 intrusions from around the world.

N27. Geologic map of the Amphitheater Mountains and south-central Alaska showing the location and names of mafic-ultramafic complexes that are part of the Nikolai large igneous province..

N28. Graphs showing platinum-group-element prices for platinum, palladium, rhodium, iridium, ruthenium, and osmium from 1880 to 2013

\section{Tables}

N1. Chemical formulas for selected platinum-group minerals as well as other common rock-forming minerals mentioned in this chapter

N2. Examples of rocks and ores with anomalous platinum-group-element concentrations that are not associated with magmatic deposits, by deposit type.

N3. Areas with significant placer platinum production, and estimates of cumulative production and grades.

N4. Identified platinum-group-element and gold resources, summarized by deposit type and location

N5. Igneous intrusions and intrusive complexes that contain more than 97 percent of the world's identified platinum-group-element (PGE) and gold resources, in order of total contained PGEs

N6. Areal extent and stratigraphic thickness of layered intrusions with reef-type platinum-group-element deposits and some examples of large intrusions with no known deposits, in order of areal extent.

N7. Platinum-group-element concentrations in samples of upper crust, loess, river sediment, and marine pelagic sediment...

N8. Trace element geochemistry of waters from selected reef-type, contact-type, and conduit-type deposits.

N9. Acid-base accounting for selected reef-type, contact-type, and conduit-type deposits

N10. Grade and tonnage of mineralized rock remaining in platinum-group-element-bearing mineral deposits. 


\section{Conversion Factors}

International System of Units to Inch/Pound

\begin{tabular}{|c|c|c|}
\hline Multiply & By & To obtain \\
\hline \multicolumn{3}{|c|}{ Length } \\
\hline $\operatorname{angstrom~}(\AA)$ (0.1 nanometer) & 0.003937 & microinch \\
\hline angstrom $(\AA)$ (0.1 nanometer) & 0.000003937 & mil \\
\hline micrometer $(\mu \mathrm{m})$ [or micron] & 0.03937 & mil \\
\hline millimeter $(\mathrm{mm})$ & 0.03937 & inch (in.) \\
\hline centimeter $(\mathrm{cm})$ & 0.3937 & inch (in.) \\
\hline meter $(\mathrm{m})$ & 3.281 & foot $(\mathrm{ft})$ \\
\hline meter $(\mathrm{m})$ & 1.094 & yard (yd) \\
\hline kilometer $(\mathrm{km})$ & 0.6214 & mile (mi) \\
\hline \multicolumn{3}{|c|}{ Area } \\
\hline hectare (ha) & 2.471 & acre \\
\hline square kilometer $\left(\mathrm{km}^{2}\right)$ & 247.1 & acre \\
\hline square meter $\left(\mathrm{m}^{2}\right)$ & 10.76 & square foot $\left(\mathrm{ft}^{2}\right)$ \\
\hline square centimeter $\left(\mathrm{cm}^{2}\right)$ & 0.1550 & square inch $\left(\mathrm{ft}^{2}\right)$ \\
\hline square kilometer $\left(\mathrm{km}^{2}\right)$ & 0.3861 & square mile $\left(\mathrm{mi}^{2}\right)$ \\
\hline \multicolumn{3}{|c|}{ Volume } \\
\hline milliliter $(\mathrm{mL})$ & 0.03381 & ounce, fluid (fl. oz) \\
\hline $\operatorname{liter}(\mathrm{L})$ & 33.81402 & ounce, fluid (fl. oz) \\
\hline liter (L) & 1.057 & quart (qt) \\
\hline $\operatorname{liter}(\mathrm{L})$ & 0.2642 & gallon (gal) \\
\hline cubic meter $\left(\mathrm{m}^{3}\right)$ & 264.2 & gallon (gal) \\
\hline cubic centimeter $\left(\mathrm{cm}^{3}\right)$ & 0.06102 & cubic inch $\left(\mathrm{in}^{3}\right)$ \\
\hline cubic meter $\left(\mathrm{m}^{3}\right)$ & 1.308 & cubic yard $\left(\mathrm{yd}^{3}\right)$ \\
\hline cubic kilometer $\left(\mathrm{km}^{3}\right)$ & 0.2399 & cubic mile $\left(\mathrm{mi}^{3}\right)$ \\
\hline \multicolumn{3}{|c|}{ Mass } \\
\hline microgram $(\mu g)$ & 0.00000003527 & ounce, avoirdupois (oz) \\
\hline milligram (mg) & 0.00003527 & ounce, avoirdupois (oz) \\
\hline $\operatorname{gram}(\mathrm{g})$ & 0.03527 & ounce, avoirdupois (oz) \\
\hline $\operatorname{gram}(\mathrm{g})$ & 0.03215075 & ounce, troy \\
\hline kilogram (kg) & 32.15075 & ounce, troy \\
\hline kilogram (kg) & 2.205 & pound avoirdupois (lb) \\
\hline ton, metric $(\mathrm{t})$ & 1.102 & ton, short $[2,000 \mathrm{lb}]$ \\
\hline ton, metric $(\mathrm{t})$ & 0.9842 & ton, long $[2,240 \mathrm{lb}]$ \\
\hline \multicolumn{3}{|c|}{ Deposit grade } \\
\hline gram per metric ton $(\mathrm{g} / \mathrm{t})$ & 0.0291667 & ounce per short ton $(2,000 \mathrm{lb})(\mathrm{oz} / \mathrm{T})$ \\
\hline \multicolumn{3}{|c|}{ Pressure } \\
\hline megapascal (MPa) & 10 & bar \\
\hline gigapascal (GPa) & 10,000 & bar \\
\hline \multicolumn{3}{|c|}{ Density } \\
\hline gram per cubic centimeter $\left(\mathrm{g} / \mathrm{cm}^{3}\right)$ & 62.4220 & pound per cubic foot $\left(\mathrm{lb} / \mathrm{ft}^{3}\right)$ \\
\hline milligram per cubic meter $\left(\mathrm{mg} / \mathrm{m}^{3}\right)$ & 0.00000006243 & pound per cubic foot $\left(\mathrm{lb} / \mathrm{ft}^{3}\right)$ \\
\hline \multicolumn{3}{|c|}{ Energy } \\
\hline joule $(J)$ & 0.0000002 & kilowatthour (kWh) \\
\hline joule $(\mathrm{J})$ & $6.241 \times 10^{18}$ & electronvolt (eV) \\
\hline joule $(J)$ & 0.2388 & calorie (cal) \\
\hline kilojoule $(\mathrm{kJ})$ & 0.0002388 & kilocalorie (kcal) \\
\hline
\end{tabular}


International System of Units to Inch/Pound

\begin{tabular}{|c|c|c|}
\hline Multiply & By & To obtain \\
\hline \multicolumn{3}{|c|}{ Radioactivity } \\
\hline becquerel (Bq) & 0.00002703 & microcurie $(\mu \mathrm{Ci})$ \\
\hline kilobecquerel (kBq) & 0.02703 & microcurie $(\mu \mathrm{Ci})$ \\
\hline \multicolumn{3}{|c|}{ Electrical resistivity } \\
\hline ohm meter $(\Omega-\mathrm{m})$ & 39.37 & ohm inch $(\Omega$-in.) \\
\hline ohm-centimeter $(\Omega$-cm) & 0.3937 & ohm inch $(\Omega$-in. $)$ \\
\hline \multicolumn{3}{|c|}{ Thermal conductivity } \\
\hline $\begin{array}{l}\text { watt per centimeter per degree } \\
\text { Celsius (watt } / \mathrm{cm}^{\circ} \mathrm{C} \text { ) }\end{array}$ & 693.1798 & $\begin{array}{l}\text { International British thermal unit } \\
\text { inch per hour per square foot per } \\
\text { degree Fahrenheit }\left(\mathrm{Btu} \text { in } / \mathrm{h} \mathrm{ft}^{2} \mathrm{~F}\right)\end{array}$ \\
\hline watt per meter kelvin $(\mathrm{W} / \mathrm{m}-\mathrm{K})$ & 6.9318 & $\begin{array}{l}\text { International British thermal unit } \\
\text { inch per hour per square foot per } \\
\text { degree Fahrenheit }\left(\mathrm{Btu} \text { in } / \mathrm{h} \mathrm{ft}^{2} \mathrm{~F}\right)\end{array}$ \\
\hline
\end{tabular}

Inch/Pound to International System of Units

\begin{tabular}{|c|c|c|}
\hline \multicolumn{3}{|c|}{ Length } \\
\hline mil & 25.4 & micrometer $(\mu \mathrm{m})$ [or micron] \\
\hline inch (in.) & 2.54 & centimeter $(\mathrm{cm})$ \\
\hline inch (in.) & 25.4 & millimeter $(\mathrm{mm})$ \\
\hline foot (ft) & 0.3048 & meter $(\mathrm{m})$ \\
\hline mile (mi) & 1.609 & kilometer $(\mathrm{km})$ \\
\hline \multicolumn{3}{|c|}{ Volume } \\
\hline ounce, fluid (fl. oz) & 29.57 & milliliter $(\mathrm{mL})$ \\
\hline ounce, fluid (fl. oz) & 0.02957 & liter $(\mathrm{L})$ \\
\hline \multicolumn{3}{|c|}{ Mass } \\
\hline ounce, avoirdupois (oz) & $28,350,000$ & microgram \\
\hline ounce, avoirdupois (oz) & 28,350 & milligram \\
\hline ounce, avoirdupois (oz) & 28.35 & $\operatorname{gram}(\mathrm{g})$ \\
\hline ounce, troy & 31.10348 & $\operatorname{gram}(\mathrm{g})$ \\
\hline ounce, troy & 0.03110348 & kilogram (kg) \\
\hline pound, avoirdupois (lb) & 0.4536 & kilogram (kg) \\
\hline ton, short $(2,000 \mathrm{lb})$ & 0.9072 & ton, metric $(\mathrm{t})$ \\
\hline ton, long $(2,240 \mathrm{lb})$ & 1.016 & ton, metric $(\mathrm{t})$ \\
\hline \multicolumn{3}{|c|}{ Deposit grade } \\
\hline ounce per short ton $(2,000 \mathrm{lb})(\mathrm{oz} / \mathrm{T})$ & 34.285714 & gram per metric ton $(\mathrm{g} / \mathrm{t})$ \\
\hline \multicolumn{3}{|c|}{ Energy } \\
\hline kilowatthour (kWh) & $3,600,000$ & joule $(\mathrm{J})$ \\
\hline electronvolt $(\mathrm{eV})$ & $1.602 \times 10^{-19}$ & joule $(\mathrm{J})$ \\
\hline \multicolumn{3}{|c|}{ Radioactivity } \\
\hline microcurie $(\mu \mathrm{Ci})$ & 37,000 & becquerel $(\mathrm{Bq})$ \\
\hline microcurie $(\mu \mathrm{Ci})$ & 37 & kilobecquerel $(\mathrm{kBq})$ \\
\hline
\end{tabular}

Temperature in degrees Celsius $\left({ }^{\circ} \mathrm{C}\right)$ may be converted to degrees Fahrenheit $\left({ }^{\circ} \mathrm{F}\right)$ as follows:

$$
{ }^{\circ} \mathrm{F}=\left(1.8 \times{ }^{\circ} \mathrm{C}\right)+32
$$

Temperature in degrees Celsius $\left({ }^{\circ} \mathrm{C}\right)$ may be converted to kelvin $(\mathrm{K})$ as follows:

$$
\mathrm{K}={ }^{\circ} \mathrm{C}+273.15
$$

Temperature in degrees Fahrenheit $\left({ }^{\circ} \mathrm{F}\right)$ may be converted to degrees Celsius $\left({ }^{\circ} \mathrm{C}\right)$ as follows:

$$
{ }^{\circ} \mathrm{C}=\left({ }^{\circ} \mathrm{F}-32\right) / 1.8
$$




\section{Datum}

Unless otherwise stated, vertical and horizontal coordinate information is referenced to the World Geodetic System of 1984 (WGS 84). Altitude, as used in this report, refers to distance above the vertical datum.

\section{Supplemental Information}

Specific conductance is given in microsiemens per centimeter at 25 degrees Celsius $(\mu \mathrm{S} / \mathrm{cm}$ at $\left.25^{\circ} \mathrm{C}\right)$.

Concentrations of chemical constituents in soils and (or) sediment are given in milligrams per kilogram (mg/kg), parts per million (ppm), or parts per billion (ppb).

Concentrations of chemical constituents in water are given in milligrams per liter (mg/L), micrograms per liter $(\mu \mathrm{g} / \mathrm{L})$, nanogams per liter $(\mathrm{ng} / \mathrm{L})$, nanomoles per kilogram $(\mathrm{nmol} / \mathrm{kg})$, parts per million (ppm), parts per billion (ppb), or parts per trillion (ppt).

Concentrations of suspended particulates in water are given in micrograms per gram $(\mu \mathrm{g} / \mathrm{g})$, milligrams per kilogram $(\mathrm{mg} / \mathrm{kg})$, or femtograms per gram $(\mathrm{fg} / \mathrm{g})$.

Concentrations of chemicals in air are given in units of the mass of the chemical (milligrams, micrograms, nanograms, or picograms) per volume of air (cubic meter).

Activities for radioactive constituents in air are given in microcuries per milliliter $(\mu \mathrm{Ci} / \mathrm{mL})$.

Deposit grades are commonly given in percent, grams per metric ton $(\mathrm{g} / \mathrm{t})$-which is equivalent to parts per million (ppm) — or troy ounces per short ton (oz/T).

Geologic ages are expressed in mega-annum (Ma, million years before present, or $10^{6}$ years ago) or giga-annum ( $\mathrm{Ga}$, billion years before present, or $10^{9}$ years ago).

For ranges of years, "to" and (or) the en dash ("-") mean "up to and including."

\begin{tabular}{ll}
\hline \multicolumn{1}{c}{ Concentration unit } & \multicolumn{1}{c}{ Equals } \\
\hline milligram per kilogram $(\mathrm{mg} / \mathrm{kg})$ & part per million \\
microgram per gram $(\mu \mathrm{g} / \mathrm{g})$ & part per million \\
microgram per kilogram $(\mu \mathrm{g} / \mathrm{kg})$ & part per billion $\left(10^{9}\right)$ \\
\hline
\end{tabular}

\section{Equivalencies}

part per million (ppm): $1 \mathrm{ppm}=1,000 \mathrm{ppb}=1,000,000 \mathrm{ppt}=0.0001$ percent part per billion (ppb): $0.001 \mathrm{ppm}=1 \mathrm{ppb}=1,000 \mathrm{ppt}=0.0000001$ percent part per trillion (ppt): $0.000001 \mathrm{ppm}=0.001 \mathrm{ppb}=1 \mathrm{ppt}=0.0000000001$ percent

\section{Metric system prefixes}

$\begin{array}{lll}\text { tera- (T-) } & 10^{12} & 1 \text { trillion } \\ \text { giga- (G-) } & 10^{9} & 1 \text { billion } \\ \text { mega- (M-) } & 10^{6} & 1 \text { million } \\ \text { kilo- (k-) } & 10^{3} & 1 \text { thousand } \\ \text { hecto- (h-) } & 10^{2} & 1 \text { hundred } \\ \text { deka- (da-) } & 10 & 1 \text { ten } \\ \text { deci- (d-) } & 10^{-1} & 1 \text { tenth } \\ \text { centi- }(\mathrm{c}-) & 10^{-2} & 1 \text { hundredth } \\ \text { milli- }(\mathrm{m}-) & 10^{-3} & 1 \text { thousandth } \\ \text { micro- }(\mu-) & 10^{-6} & 1 \text { millionth } \\ \text { nano- }(\mathrm{n}-) & 10^{-9} & 1 \text { billionth } \\ \text { pico- (p-) } & 10^{-12} & 1 \text { trillionth } \\ \text { femto- (f-) } & 10^{-15} & 1 \text { quadrillionth } \\ \text { atto- (a-) } & 10^{-18} & 1 \text { quintillionth }\end{array}$




\section{Abbreviations and Symbols}

\begin{tabular}{|c|c|}
\hline${ }^{\circ} \mathrm{C}$ & degree Celsius \\
\hline$\mu \mathrm{m}$ & micrometer \\
\hline $\mathrm{cm}$ & centimeter \\
\hline $\mathrm{g} / \mathrm{t}$ & gram per metric ton \\
\hline ICP-MS & inductively coupled plasma-mass spectrometry \\
\hline $\mathrm{kg}$ & kilogram \\
\hline $\mathrm{kg} \mathrm{CaCO}_{3} / \mathrm{t}$ & kilogram of calcium carbonate per metric ton \\
\hline km & kilometer \\
\hline $\mathrm{km}^{2}$ & square kilometer \\
\hline $\mathrm{km}^{3}$ & cubic kilometer \\
\hline LED & light-emitting diode \\
\hline LIP & large igneous province \\
\hline m & meter \\
\hline Ma & mega-annum \\
\hline MSS & monosulfide solution \\
\hline m.y. & million years \\
\hline PEM & proton exchange membrane \\
\hline PGE & platinum-group element \\
\hline PGM & platinum-group metal \\
\hline ppb & part per billion \\
\hline ppm & part per million \\
\hline ppt & part per trillion \\
\hline USGS & U.S. Geological Survey \\
\hline
\end{tabular}





\title{
Platinum-Group Elements
}

\author{
By Michael L. Zientek, Patricia J. Loferski, Heather L. Parks, Ruth F. Schulte, and Robert R. Seal II
}

\section{Abstract}

The platinum-group elements (PGEs) — platinum, palladium, rhodium, ruthenium, iridium, and osmium — are metals that have similar physical and chemical properties and tend to occur together in nature. PGEs are indispensable to many industrial applications but are mined in only a few places. The availability and accessibility of PGEs could be disrupted by economic, environmental, political, and social events. The United States net import reliance as a percentage of apparent consumption is about 90 percent.

PGEs have many industrial applications. They are used in catalytic converters to reduce carbon monoxide, hydrocarbon, and nitrous oxide emissions in automobile exhaust. The chemical industry requires platinum or platinum-rhodium alloys to manufacture nitric oxide, which is the raw material used to manufacture explosives, fertilizers, and nitric acid. In the petrochemical industry, platinum-supported catalysts are needed to refine crude oil and to produce aromatic compounds and high-octane gasoline. Alloys of PGEs are exceptionally hard and durable, making them the best known coating for industrial crucibles used in the manufacture of chemicals and synthetic materials. PGEs are used by the glass manufacturing industry in the production of fiberglass and flat-panel and liquid crystal displays. In the electronics industry, PGEs are used in computer hard disks, hybridized integrated circuits, and multilayer ceramic capacitors.

Aside from their industrial applications, PGEs are used in such other fields as health, consumer goods, and finance. Platinum, for example, is used in medical implants, such as pacemakers, and PGEs are used in cancer-fighting drugs. Platinum alloys are an ideal choice for jewelry because of their white color, strength, and resistance to tarnish. Platinum, palladium, and rhodium in the form of coins and bars are also used as investment commodities, and various financial instruments based on the value of these PGEs are traded on major exchanges.

PGEs are among the rarest metals; Earth's upper crust contains only about 0.0005 part per million (ppm) platinum. Today, the average grade of PGEs in ores that are mined primarily for their PGE concentrations varies from 5 to $15 \mathrm{ppm}$, although the concentration of PGEs in hand-picked ore specimens may range from tens to hundreds of parts per million.
More than 100 different minerals have one of the PGEs as an essential component. PGE minerals occur as native metals. They also occur as compounds with other transition metals (copper, iron, mercury, nickel, and silver), post-transition metals (bismuth, lead, and tin), metalloids (antimony, arsenic, and tellurium), and nonmetals (selenium and sulfur).

From 1900 to 2011, approximately 14,200 metric tons of PGEs was produced, and roughly 95 percent of that production (13,500 metric tons) took place between 1960 and 2011. The breakdown of production by country shows that, since 1900 , about 90 percent of the production came from South Africa and Russia. The secondary supply of platinum, palladium, and rhodium is obtained through the recycling of catalytic converters from end-of-life vehicles, jewelry, and electronic equipment. Recycled platinum, palladium, and rhodium provide a significant proportion of the world's total supply; these secondary sources are sufficient to close the gap between world mine production and consumption.

Exploration and mining companies report resources of about 104,000 metric tons of PGEs (including minor amounts of gold) in mineral deposits around the world that could be developed. For PGEs, almost all the reported production and identified resources are associated with deposits in three geologic features - the Bushveld Complex, which is a layered mafic to ultramafic intrusion in South Africa; the Great Dyke, which is a layered mafic to ultramafic intrusion in Zimbabwe; and sill-like intrusions associated with flood basalts in the Noril'sk-Talnakh area of Russia.

The metallic forms of PGEs are generally considered to be inert. PGEs pose a risk to human health only in cases where individuals are occupationally exposed to synthetic PGE compounds, especially workers in precious-metal refineries. In the natural environment, background PGE concentrations are low in water, sediment, soil, and plants. Anthropogenic sources of PGEs in the environment include catalytic converters used in modern automobiles, platinum-based chemotherapy drugs, and smelter emissions.

The abundance of sulfide minerals defines the environmental and geologic characteristics of PGE-enriched magmatic sulfide deposits; those deposits with the highest amount of sulfide minerals could have the highest environmental impact. Acid rock drainage from reef-type and contact-type deposits 
is unlikely because the ores and their host rocks contain low proportions of sulfide minerals. For some conduit-type orebodies with massive ores, mineral-processing techniques separate and produce concentrates of copper-, iron-, and nickel-bearing sulfide minerals; those with copper and nickel are processed to extract metal, but the iron-sulfide minerals, mainly pyrrhotite, are discarded as waste. This results in waste material with a high acid-generating potential.

The most significant primary source of PGEs in the United States is a deposit in the Stillwater Complex, which is a layered igneous intrusion in Montana. Approximately 305 metric tons of platinum and palladium have been mined from the Stillwater Complex deposit since 1986. Exploration and development drilling indicate that another 2,200 metric tons are present. Mining has progressed to depths of 1,800 meters below the surface, but the bottom of the ore deposit has not been reached; geologic estimates suggest that another 1,000 to 6,200 metric tons of PGEs could be present at depth. In the future, PGEs may be mined from deposits found near the base of the Duluth Complex, which is a group of igneous intrusions in Minnesota.

\section{Introduction}

The platinum-group elements (PGEs) — platinum, palladium, rhodium, ruthenium, iridium, and osmium - are chemical elements that have similar physical and chemical properties and tend to occur together in nature. They are transition metals, lying in Group 8B and periods 5 and 6 of the periodic table of elements. Along with gold and silver, they are also precious metals that have high economic value determined not only by their practical uses but also by their role as investment instruments and as a store of value. The PGEs are also known as the platinum-group metals (PGMs).

Pre-Columbian peoples found naturally occurring platinum and platinum-rich alloys in stream deposits in Colombia and Ecuador. In the 1500s, Spanish colonists also found grains of these alloys mingled with gold nuggets they recovered from stream deposits in the same area; they called the metal "platina" (McDonald and Hunt, 1982). At that time, the metal had no known use and was considered worthless. The platinum-rich grains were a nuisance because they could not be separated from gold nuggets by panning. Small samples of platinum-enriched nuggets from South America reached Europe during the 1740s. Platinum was described as a new metal in 1750, followed by iridium and osmium in 1803, palladium and rhodium in 1804, and ruthenium in 1807 . The unique properties of the metals were realized later in the 19th century.

PGEs are essential for important industrial applications but are mined in only a limited number of places. Therefore, the availability and accessibility of PGEs could be disrupted by economic, environmental, political, and social events. This is not a new development. During World War I, the United States considered platinum a "vital war material" needed for the production of amplifiers, magnetos, munitions, shell primers, and sulfuric acid, and it was ranked second on the "list of strategic raw material" for which the United States was either entirely or partially dependent on foreign countries (Lael and Killen, 1982). During World War II, these metals had even greater strategic importance to science and industry, and the United States was still dependent on sources in foreign countries (DeMille, 1947; U.S. Bureau of Mines and U.S. Geological Survey, 1947). Security of supply was also a concern during the Cold War (U.S. Congress, Office of Technology Assessment, 1985; Sutphin and Page, 1986). With the dissolution of the Soviet Union and the peaceful transition of government in South Africa in the early 1990s, import vulnerability became less of an immediate concern. The United States net import reliance as a percentage of apparent consumption is still about 90 percent, however, and the main sources of these elements are still limited to a few mineral deposits in South Africa and Russia (Loferski, 2012a, b). The potential restrictions on supplies of critical raw minerals, such as the PGEs, have again become a topic for international concern and discussion (National Research Council of the National Academies, 2008; Buchert and others, 2009; European Commission, 2010; American Physical Society Panel on Public Affairs and Material Research Society, 2011; British Geological Survey, 2012).

This chapter summarizes how the PGEs are used, gives an overview of where PGEs are mined, and summarizes how much mineralized material has been found by mineral exploration companies. The geology of significant deposits is described, and the assessment for undiscovered resources is discussed, as are possible topics for future research. The report also discusses environmental aspects of the PGEs, including their sources and fate in the environment; mine waste characteristics; and human health, ecological, and carbon footprint concerns. Where indicated, data in tables 1 through 9 are taken from data prepared by the authors in table 10 (back of chapter).

\section{Uses, Applications, and Consumption}

The PGEs possess excellent catalytic and stable electrical properties. PGEs are also highly resistant to wear, tarnishing, and chemical attack, and can withstand high temperatures, making them indispensable to many industrial applications. Their leading use is as catalysts for oxidation and reduction reactions that decrease hydrocarbon, carbon monoxide, and nitrous oxide emissions in automobile exhaust (fig. N1). The chemical industry requires either platinum or platinumrhodium alloy to manufacture nitric oxide, which is a raw material used to manufacture explosives, fertilizers, and nitric acid. PGEs are also used in the production of specialty silicones, which, in turn, have many uses, such as in coatings on automobile airbags, water repellent coatings, and adhesives for sticky notes. In the petrochemical industry, platinumsupported catalysts are needed to refine crude oil and to produce high-octane gasoline and aromatic compounds. 

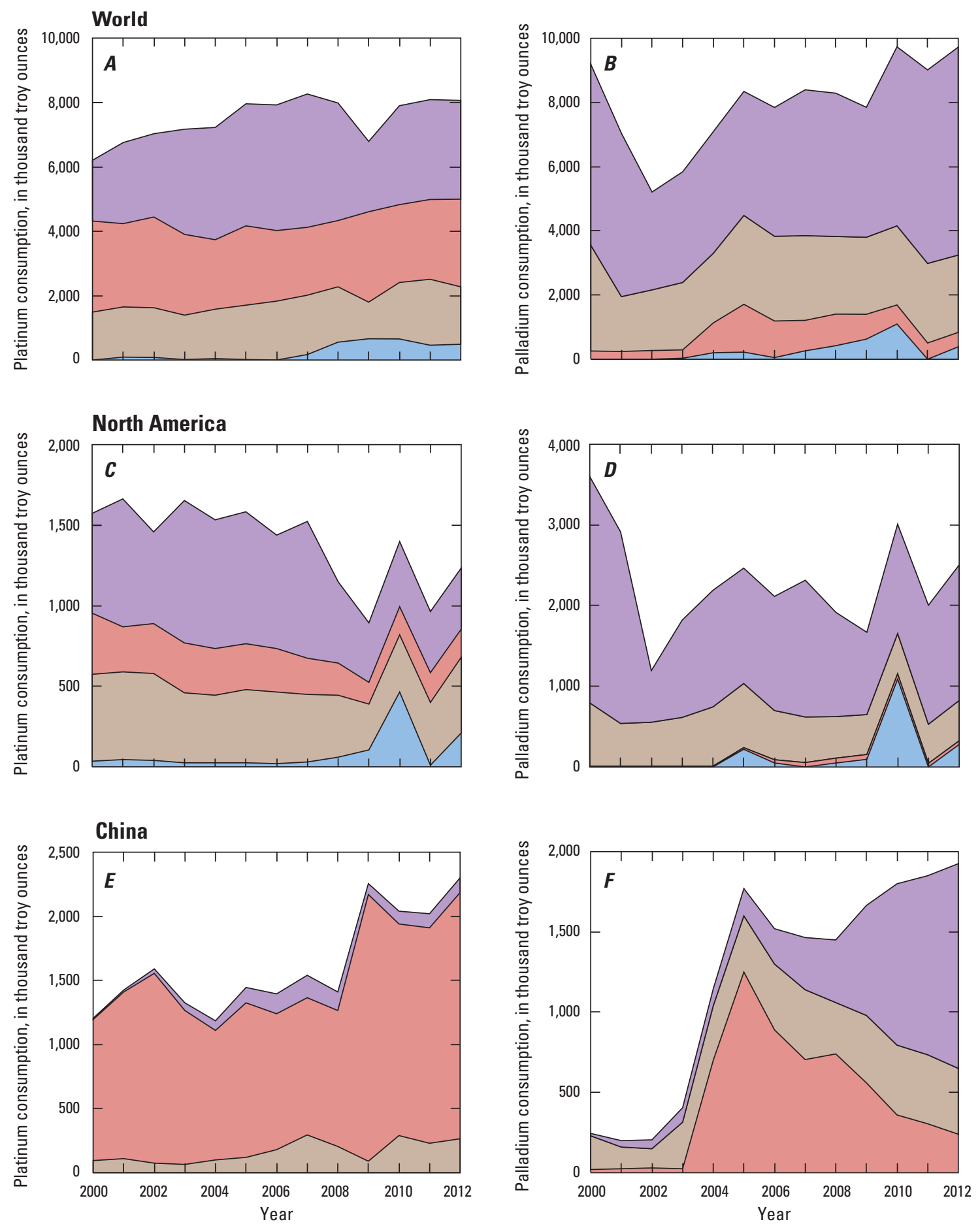

Figure N1. Graphs showing platinum and palladium consumption, by category of use, from 2000 to 2012 for the world $(A$ and $B)$, North America $(C$ and $D)$, and China $(E$ and $F)$. The decrease in platinum consumption for North America is directly related to the decreased production of cars and trucks during the same period (Organisation Internationale des Constructeurs d'Automobiles, 2013). The graphs also illustrate how consumption of platinum jewelry varies by region. In each graph, the layers are placed one above the other, forming a cumulative total. Created from data in Platinum Today (2013c).

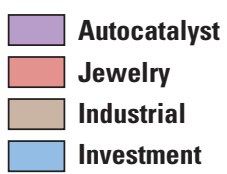


Alloys of PGEs are exceptionally hard and durable, making them the best known coating for industrial crucibles used in the manufacture of chemicals and synthetic materials, such as high-purity single crystals used in the production of light-emitting diodes (LEDs). PGEs are used by the glass manufacturing industry in the production of fiberglass and flat-panel and liquid crystal displays. In the electronics industry, PGEs are used in computer hard disks to increase storage capacity, and they are ubiquitous in electronic devices, hybridized integrated circuits, and multilayer ceramic capacitors. Platinum does not corrode inside the body, and allergic reactions to platinum are extremely rare; therefore, it is used in medical implants, such as pacemakers. PGEs are also used in cancer-fighting drugs. Other uses of PGEs include gas sensors in automobiles and homes, spark plug tips, and additives to superalloys (Impala Platinum Holdings Ltd., 2012; Loferski, 2013a; Platinum Today, 2013a).

Their white color, strength, and resistance to tarnish make platinum alloys an ideal choice for jewelry (Platinum Today, 2013b). In parts of Ecuador and Colombia before the Spanish conquest, platinum was used by indigenous peoples for the fabrication of small objects, as well as sintered with gold, and incorporated into bimetallic and platinum-clad articles (fig. N2; Scott and Bray, 1980; Meeks and others, 2002; Noguez and others, 2006). Their masterworks reflect a high degree of technical innovation because the high melting temperature of platinum (1,769 degrees Celsius $\left[{ }^{\circ} \mathrm{C}\right]$ ) requires sophisticated manufacturing techniques and craftsmanship. The modern tradition of using platinum for jewelry began in Europe in the 18th century. The works produced by Cartier and Tiffany in the late 19 th century and early 20 th century created interest in platinum jewelry, particularly in the United States. The Great Depression of the 1930s and the advent of World War II suppressed the platinum jewelry market in the United States. In the 1960s, demand for platinum jewelry in Japan surged, followed by a surge in demand in China in the mid-1990s.

Platinum, palladium, and rhodium are also used for investment in the form of physical or financial assets. Physical assets include platinum and palladium as collectible coins, or as bullion coins, bars, or wafers. Financial assets include stocks, mutual funds, and exchange-traded funds. Financial assets allow investors to own platinum, palladium, and rhodium without the difficulties associated with physically holding the metal.

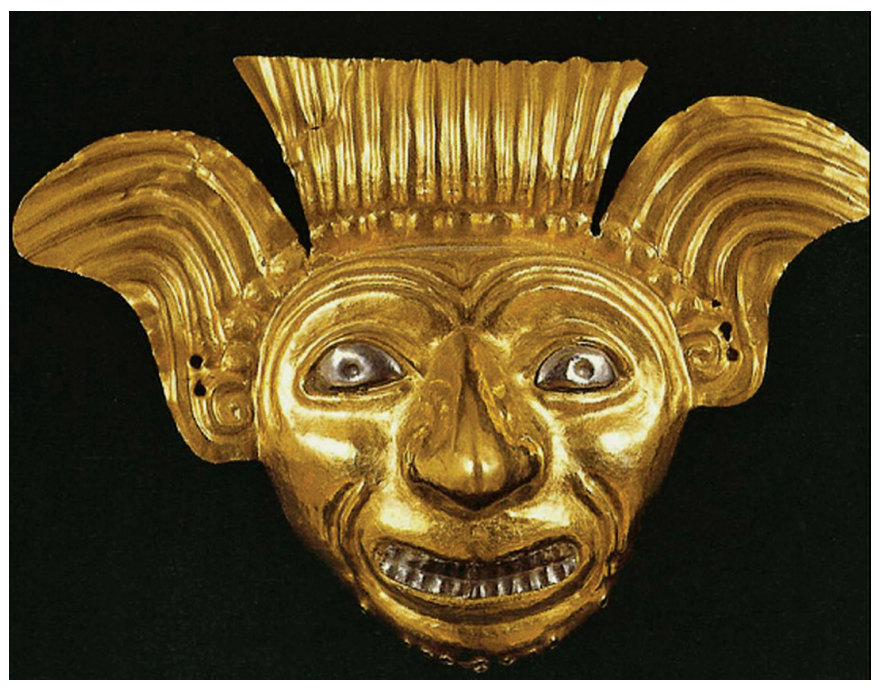

Figure N2. Photograph of gold mask with platinum highlights, from the period of La Tolita culture, Ecuador. From Museo Nacional del Banco Central del Ecuador collection.

\section{Geology \\ Geochemistry}

All chemical elements heavier than oxygen, including the PGEs, are created by nuclear fusion and nucleosynthesis processes during supernova explosions. The matter derived from supernova explosions is dispersed into the interstellar medium and enriches molecular clouds, which are sites of star and planetary formation. Earth formed from the same cloud of matter as the sun, so the bulk PGE composition of Earth is thought to be similar to that of the solar system. Carbonaceous meteorites of the Ivuna type (carbonaceous chondrites [type 1], or C1 chondrites) are used to estimate solar system abundances (Lodders, 2010). The Orgueil meteorite, which is considered most representative of the $\mathrm{C} 1$ chondrites, contains 0.947 part per million (ppm) platinum.

Early in its evolution, Earth differentiated into a metallic core, a silicate mantle, and a silicate crust. The segregation processes affected the distribution of the PGEs and resulted in concentrations progressively decreasing from core to mantle to upper crust. The range of platinum concentration in samples of iron meteorites, which are perhaps the best analogs for the composition of Earth's core, is 2.4 to $16 \mathrm{ppm}$ (Wasson and others, 1989). The average platinum concentrations of samples of the upper mantle vary from about 0.002 to $0.005 \mathrm{ppm}$ ( 2 to 5 parts per billion [ppb]) (Maier and others, 2012). In contrast, the upper crust is estimated to contain only $0.0005 \mathrm{ppm}(0.5 \mathrm{ppb}$ ) platinum (Rudnick and Gao, 2003). Today, the average grade of PGEs in ores that are mined primarily for their PGE concentrations ranges from 5 to $15 \mathrm{ppm}$; however, the concentration of PGEs in hand-picked ore specimens may range from tens to hundreds of parts per million. 


\section{Mineralogy}

The PGEs can occur as an essential component of the crystal structure of a mineral (a naturally occurring inorganic element or compound having a periodically repeating arrangement of atoms and characteristic chemical composition, resulting in distinctive physical properties). The Commission on New Minerals, Nomenclature and Classification of the International Mineralogical Association has recognized more than 100 different minerals in which at least one of the PGEs is an essential component (Cabri, 2002); they are called platinum-group minerals. Platinum-group minerals include native-metal-minerals and compounds with other transition metals (such as copper, iron, mercury, nickel, and silver), post-transition metals (such as bismuth, lead, and tin), metalloids (such as antimony, arsenic, and tellurium), and nonmetals (such as selenium and sulfur) (table N1). In most rocks, platinum-group minerals are fine-grained and range in size from less than a micron to a few hundred microns in diameter. Most geologists can spend a lifetime working on rocks enriched in PGEs and never see a platinum-group mineral in a hand specimen. Yet the platinum-group minerals are important to characterize because information about their mineralogy is needed to extract metals from their ore minerals effectively and to understand ore-forming processes.

PGEs also occur in solid solution in base-metal sulfides and sulfarsenides. In solid solution, different chemical elements can substitute in specific atomic sites without changing a mineral's crystalline structure. For example, palladium can substitute for nickel in pentlandite (Cabri, 1992); the amount of substitution can be significant and is detectable by several microanalytical techniques. PGEs also occur in solid solution in nickeliferous cobaltite (nickel-iron sulfarsenide) in ores mined at the Copper Cliff North Mine in Sudbury, Ontario, Canada (Szentpéteri and others, 2002). Low-level concentrations of PGEs in solid solution in base-metal sulfide minerals can be assessed using laser-ablation inductively coupled plasma-mass spectrometry (ICP-MS) (for example, Cabri and others, 2003; Godel and others, 2007; Pagé and others, 2012). These studies document that pentlandite is the principal base-metal sulfide mineral that hosts PGEs. Pyrrhotite $\left(\mathrm{Fe}_{1-\mathrm{x}} \mathrm{S}\right)$ can contain some iridium, osmium, rhodium, and ruthenium, but not palladium or platinum. Chalcopyrite $\left(\mathrm{CuFeS}_{2}\right)$ does not contain significant amounts of PGEs in solid solution. Platinum and gold do not partition into base-metal sulfide minerals.

\section{Deposit Types}

Mineral deposits can be classified into groups or types based on common features and associations that ultimately relate to the underlying geologic processes that formed the ore. Each mineral deposit type has characteristic geometries, distributions of tonnage and grade, and rock and mineral properties that determine the potential value of the deposit. Each deposit type also has specific characteristics that determine how much sampling will be required to delimit the deposit's mineral resources and in what manner the valuable material will be mined and processed. Furthermore, each deposit type exerts a specific impact on the environment, whether through natural weathering processes or the result of mining.

At a basic level, economic geologists recognize the following mineral deposit types: (a) magmatic_-formed during the cooling and crystallization of magma, (b) hydrothermal - formed by the interaction of hot water and rock, (c) sedimentary-formed by the precipitation or settling of minerals directly from water in oceans or lakes, (d) residual-formed by the intense weathering of rocks under hot, humid conditions, and (e) placers - formed by the physical concentration of heavy particles of rocks or minerals by the action of moving water. PGE-enriched rocks can be found in each of the deposit types listed above. The following sections describe examples of PGE mineralization found in each of these deposit types. More information is given for magmatic deposits because they are the source of almost all the PGEs recovered by mining. The locations of the world's major and minor PGE deposits are shown in figure N3.

\section{Magmatic Deposits}

PGEs are transferred from Earth's mantle to its crust by magnesium-rich magmas that were formed by the melting of a high percentage of mantle material from which magma had not been previously extracted. A high degree of partial melting is needed to release PGEs into the melt from the small quantities of sulfide minerals or alloys that are present in the mantle. Upon emplacement in the crust, the magnesium-rich magmas cool to form mafic and ultramafic igneous rocks.

Magmatic deposits are concentrations of metallic oxide or sulfide minerals that formed during the cooling and crystallization of magma. Textural and experimental evidence indicate that PGE-enriched mineralization forms when mafic to ultramafic magma becomes saturated with sulfur and an immiscible sulfide liquid exsolves from the silicate magma (Barnes and others, 2008; Holwell and McDonald, 2010; Naldrett, 2010a). The solubility of sulfur in mafic magmas is affected by changes in the bulk composition of the magma, the fugacity of sulfur and oxygen, temperature, and pressure (Ripley, 1999). Processes that change the solubility of sulfur and may cause an exsolution event include (a) fractional crystallization of the silicate magma, (b) mixing of magmas, (c) assimilation of additional sulfur from sources external to the magma, and (d) modification of the magma composition by bulk contamination, such as changing the silica content of the magma (Mungall, 2005).

The silicate magma solidifies first, followed by the sulfide liquid, which solidifies at temperatures in excess of $900{ }^{\circ} \mathrm{C}$. The textures and mineralogy of PGE ores record a prolonged and complex process of solid-state transformation and 
Table N1. Chemical formulas for selected platinum-group minerals as well as other common rock-forming minerals mentioned in this chapter.

[Sources: Deer and others (1966); Vaughan and Craig (1978); and Cabri (2002). Elements: Al, aluminum; As, arsenic; Bi, bismuth; C, carbon; $\mathrm{Ca}$, calcium; Cr, chromium; Cu, copper; Fe, iron; Hg, mercury; Ir, iridium; K, potassium; Mg, magnesium; Na, sodium; Ni, nickel; O, oxygen; Os, osmium; Rh, rhodium; Ru, ruthenium; Pb, lead; Pd, palladium; Pt, platinum; S, sulfur; Sb, antimony; Si, silicon; Sn, tin; Te, tellurium]

\begin{tabular}{|c|c|c|c|}
\hline Mineral name & Chemical formula & Mineral name & Chemical formula \\
\hline \multicolumn{2}{|c|}{ PLATINUM-GROUP MINERALS } & \multicolumn{2}{|c|}{ BASE-METAL SULFIDE MINERALS } \\
\hline \multicolumn{2}{|c|}{ Native metals } & Bornite & $\mathrm{Cu}_{5} \mathrm{FeS}_{4}$ \\
\hline Iridium & Ir & Chalcopyrite & $\mathrm{CuFeS}_{2}$ \\
\hline Osmium & Os & Covellite & $\mathrm{CuS}$ \\
\hline Palladium & $\mathrm{Pd}$ & & \\
\hline Platinum & $\mathrm{Pt}$ & Cubanite & $\mathrm{CuFe}_{2} \mathrm{~S}_{3}$ \\
\hline Rhodium & $\mathrm{Rh}$ & Marcasite & $\mathrm{FeS}_{2}$ \\
\hline Ruthenium & $\mathrm{Ru}$ & Mooihoekite & $\mathrm{Cu}_{9} \mathrm{Fe}_{9} \mathrm{~S}_{16}$ \\
\hline \multicolumn{2}{|c|}{ Compounds with transition metals } & Nickeliferous cobaltite & $\mathrm{Co}(\mathrm{Ni}) \mathrm{AsS}$ \\
\hline Isoferroplatinum & $\mathrm{Pt}_{3} \mathrm{Fe}$ & Pentlandite & $(\mathrm{Fe}, \mathrm{Ni})_{9} \mathrm{~S}_{8}$ \\
\hline Potarite & $\mathrm{PdHg}$ & Pyrite & $\mathrm{FeS}_{2}$ \\
\hline Tulameenite & $\mathrm{PtFe}_{0.5} \mathrm{Cu}_{0.5}$ & Pyrrhotite & $\mathrm{Fe}^{2} \mathrm{~S}$ \\
\hline \multicolumn{2}{|c|}{ Compounds with post-transition metals ( $\mathrm{Bi}, \mathrm{Pb}$, and $\mathrm{Sn})$} & Pyrrnotite & $\mathrm{Fe}_{(1-\mathrm{x})}^{\mathrm{S}}$ \\
\hline Atokite & $\mathrm{Pd}_{3} \mathrm{Sn}$ & Talnakhite & $\mathrm{Cu}_{9}(\mathrm{Fe}, \mathrm{Ni})_{8} \mathrm{~S}_{16}$ \\
\hline Froodite & $\mathrm{PdBi}_{2}$ & Troilite & $\mathrm{FeS}$ \\
\hline Insizwaite & $\mathrm{PtBi}_{2}$ & \multicolumn{2}{|c|}{ OTHER ROCK-FORMING MINERALS } \\
\hline Rustenburgite & $\mathrm{Pt}_{3} \mathrm{Sn}$ & Calcite & $\mathrm{CaCO}_{3}$ \\
\hline Paolovite & $\mathrm{Pd}_{2} \mathrm{Sn}$ & Chlorite & $(\mathrm{Mg}, \mathrm{Fe})_{3}(\mathrm{Si}, \mathrm{Al})_{4} \mathrm{O}_{10}(\mathrm{OH})_{2}$ \\
\hline \multicolumn{2}{|c|}{ Compounds with metalloids } & & $(\mathrm{Mg}, \mathrm{Fe})_{3}(\mathrm{OH})_{6}$ \\
\hline Genkinite & $(\mathrm{Pt}, \mathrm{Pd})_{4} \mathrm{Sb}_{3}$ & Chromite & $(\mathrm{Fe}, \mathrm{Mg})(\mathrm{Cr}, \mathrm{Al})_{2} \mathrm{O}_{4}$ \\
\hline Geversite & $\mathrm{PtSb}_{2}$ & Goethite & $\mathrm{FeO}(\mathrm{OH})$ \\
\hline Isomertieite & $\mathrm{Pd}_{11} \mathrm{Sb}_{2} \mathrm{As}_{2}$ & Gypsum & $\mathrm{CaSO}_{4}$ \\
\hline Kotulskite & PdTe & Jarosite & $\mathrm{KFe}\left(\mathrm{SO}_{4}\right)_{2}(\mathrm{OH})_{6}$ \\
\hline Merenskyite & $\mathrm{PdTe}_{2}$ & Magnetite & $\mathrm{Fe}_{3} \mathrm{O}_{4}$ \\
\hline Moncheite & $\mathrm{PtTe}_{2}$ & Native sulfur & $\mathrm{S}$ \\
\hline $\begin{array}{l}\text { Sperrylite } \\
\text { Stibiopalladinite }\end{array}$ & $\begin{array}{l}\mathrm{PtAs}_{2} \\
\mathrm{Pd}_{5+\mathrm{x}} \mathrm{Sb}_{2-\mathrm{x}}\end{array}$ & Olivine & $(\mathrm{Mg}, \mathrm{Fe})_{2} \mathrm{SiO}_{4}$ \\
\hline Stillwaterite & $\mathrm{Pd}_{8} \mathrm{As}_{3}$ & Plagioclase & $(\mathrm{Ca}, \mathrm{Na})(\mathrm{Si}, \mathrm{Al})_{4} \mathrm{O}_{8}$ \\
\hline Sudburyite & $\mathrm{PdSb}$ & Pyroxene & $\mathrm{Ca}(\mathrm{Mg}, \mathrm{Fe}) \mathrm{Si}_{2} \mathrm{O}_{6}$ to \\
\hline \multicolumn{2}{|c|}{ Compounds with nonmetals } & & $\mathrm{Mg}_{2} \mathrm{Si}_{2} \mathrm{O}_{6}$ \\
\hline Braggite & $(\mathrm{Pt}, \mathrm{Pd}) \mathrm{S}$ & Serpentine & $(\mathrm{Mg}, \mathrm{Fe})_{3} \mathrm{Si}_{2} \mathrm{O}_{5}(\mathrm{OH})_{4}$ \\
\hline Cooperite & $\mathrm{PtS}$ & Talc & $\mathrm{Mg}_{3} \mathrm{Si}_{4} \mathrm{O}_{10}(\mathrm{OH})_{2}$ \\
\hline Erlichmanite & $\mathrm{OsS}_{2}$ & & \\
\hline Laurite & $\mathrm{RuS}_{2}$ & & \\
\hline Vysotskite & $\mathrm{PdS}$ & & \\
\hline \multicolumn{2}{|c|}{ Other } & & \\
\hline Hollingworthite & RhAsS & & \\
\hline Maslovite & PtBiTe & & \\
\hline Michenerite & PdBiTe & & \\
\hline Ruarsite & RuAsS & & \\
\hline
\end{tabular}




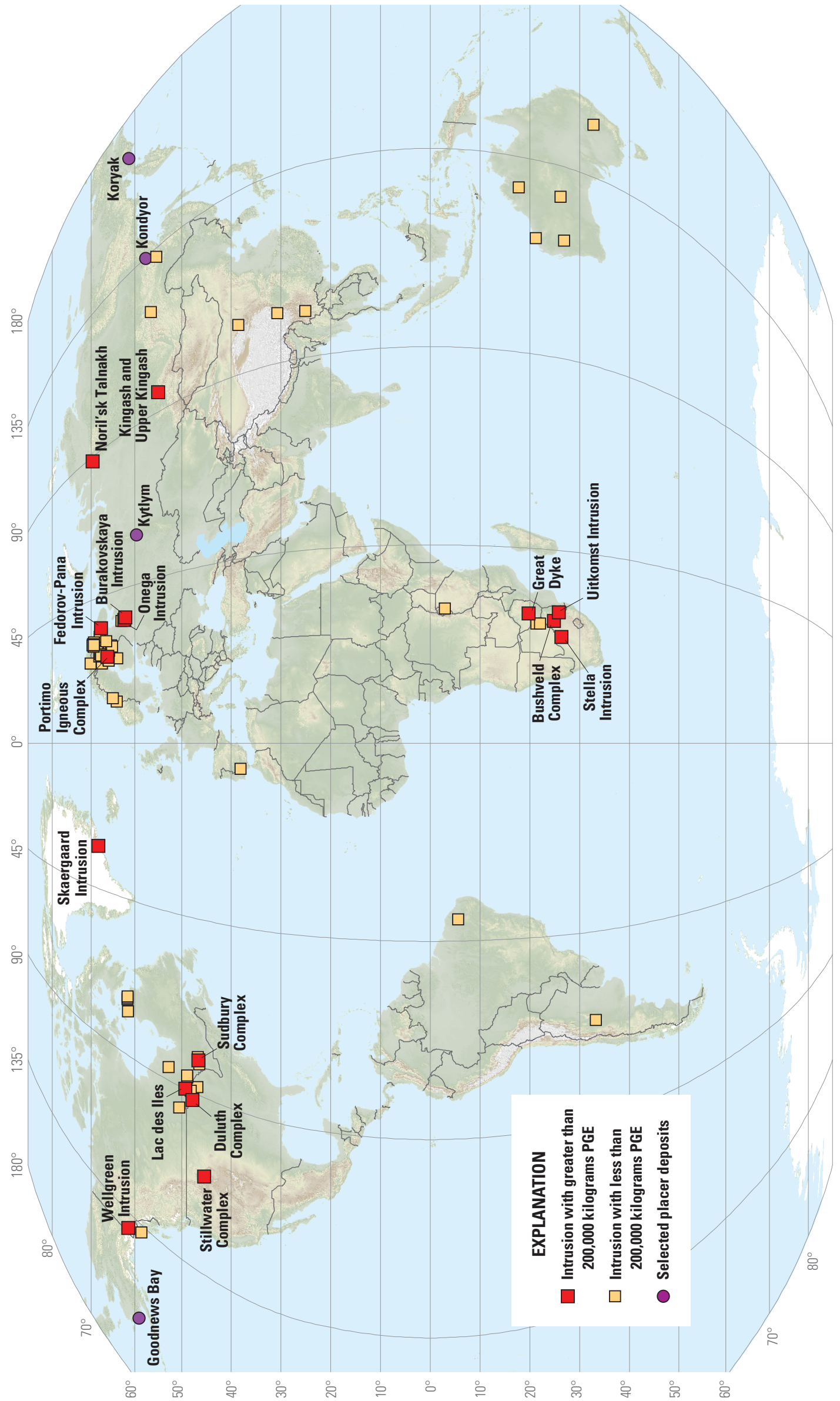

$\overline{\overline{\mathrm{j}}}$

is

离

홍

웡 응

Ш్ㅇㅇ

늠

E⿱亠丷口心

के

후요

한

틀

票

कs

흔용

항

$\stackrel{\oplus}{ \pm}$

능

范

हो

产 \&

당

흘 응

\&

징

를.

엉

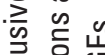

론응 뭉

릉

든

응 응

s。

$\stackrel{\square}{\circ}$ 드

品至

d

혼

o $\cong$

¿

등 을

들

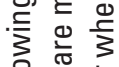

的志 흐

웧

통 홍

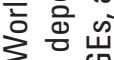

3 힘

m

言冚 
recrystallization after solidification (Barnes and others, 2008; Holwell and McDonald, 2010). At high temperature (about $1,000{ }^{\circ} \mathrm{C}$ ), osmium, iridium, and ruthenium preferentially partition from the immiscible sulfide liquid into a mineral called monosulfide solid solution (MSS). Platinum, palladium, and gold, on the other hand, behave as incompatible elements with respect to MSS and instead are concentrated in residual copper-rich sulfide liquids and associated with the minerals that crystallize from the residual immiscible sulfide liquid. Upon cooling, some of the PGEs held in sulfide crystal structures are expelled, forming discrete minerals. The final mineral assemblage consists of varied proportions of pyrrhotite, pentlandite, chalcopyrite, and bornite, with platinum and gold occurring primarily in platinum-group minerals.

Magmatic sulfide minerals in mafic to ultramafic igneous rocks do not always contain elevated concentrations of PGEs. The metal content of immiscible sulfide liquids is a function of the (a) amount of metal in the silicate magma; (b) relative affinity for metals to occur in the sulfide or silicate liquid; and (c) relative amounts of the two liquids (Campbell and Naldrett, 1979; Barnes and Maier, 1999). Such elements as copper, nickel, and PGEs originally in the silicate melt preferentially concentrate into the sulfide liquid when it exsolves. Concentration of these metals into the sulfide liquid can, under some circumstances, deplete their concentration in the silicate magma. If there is a large volume of sulfide liquid compared with that of the silicate magma, the sulfide liquids and the resulting ores will have lower concentrations of PGEs. If the sulfide liquid effectively interacts with a large volume of silicate magma, the sulfide liquids become enriched in PGEs, resulting in high-grade ores.

Economic geologists who study magmatic processes expend a lot of effort trying to understand how large mass ratios are achieved. Proposed answers have included mixing of magmas; the migration of interstitial melts (and "fluids") upward through crystal mush; and (or) the streaming of magma over sulfide liquids in a channelized lava flow, sill, or feeder dike (Barnes and Maier, 1999; Mathez, 1999; Naldrett, 2010a).

\section{Tectonic Setting of Magmatic Deposits (Large Igneous Provinces)}

As the theory of plate tectonics gained acceptance in the 1960s and its predictive power became evident, geologists, including those working on magmatic ore deposits, tried to understand magmatism and ore genesis in a plate-tectonic context (Hutchison, 1983; Sawkins, 1984). For some mafic and ultramafic rocks that are related to subduction zones and mid-oceanic ridges, this conceptual framework provided insight and clarity; however, for other types of mafic and ultramafic rocks found in intraplate settings, which include rocks that host most of the significant magmatic mineral deposit types, it did not.
Most magmatic copper-nickel-PGE deposits occur with continental flood basalts, aerially extensive mafic dike swarms, sill provinces, and large layered ultramafic-to-mafic intrusions, which are indicative of large igneous provinces (LIPs) (Coffin and Eldholm, 1994). Bryan and Ernst proposed that LIPs are magmatic provinces with areal extents greater than $1 \times 10^{5}$ square kilometers $\left(\mathrm{km}^{2}\right)$, igneous volumes greater than $1 \times 10^{5}$ cubic kilometers $\left(\mathrm{km}^{3}\right)$ and maximum lifespans of about 50 million years (m.y.) that "have intraplate tectonic settings or geochemical affinities, and are characterized by igneous pulse(s) of short duration" ( $\sim 1$ to 5 m.y.), during which time "a large proportion ( $>75$ percent) of the total igneous volume has been emplaced. [The LIPs] are dominantly mafic, but also can have significant ultramafic and silicic components, and some are dominated by silicic magmatism" (Bryan and Ernst, 2008, p. 175). Unlike the vast majority of igneous rocks that are associated with plate tectonic processes at convergent or divergent tectonic plate margins, LIP-related rocks usually occur in an intraplate tectonic setting; the association of some LIPs with hotspot tracks - for example, the North Atlantic Igneous Province and the Iceland hotspot (Storey and others, 2007) is one reason that LIPs are attributed to mantle plumes.

\section{Types of Magmatic Deposits}

Magmatic mined deposits associated with LIP-related igneous intrusions are divided into types based on such criteria as the lithology and form of associated igneous rocks, the depth of emplacement, the abundance of sulfide minerals, the relative proportion of metals, and the position of the ores within the intrusion. In this chapter, we distinguish between conduit-type deposits, which occur in intrusions that are part of sill complexes and dike swarms, and reef-type and contacttype deposits, which occur in layered intrusions (fig. N4). The most significant and representative examples for the world and the United States are the conduit-type deposits of the Noril'skTalnakh area (Russia); the reef-type deposits in South Africa (the Merensky Reef and the UG2 Chromitite), Zimbabwe (the Main Sulphide Zone), and Montana (the J-M Reef); and the contact-type deposits in South Africa (the Platreef) and Minnesota (the Duluth Complex).

\section{Conduit-Type Deposits}

The conduit-type deposits of the Noril'sk-Talnakh area of Russia are associated with an enormous outpouring of mafic magma that formed the Siberian Traps - the largest continental flood basalt province on Earth (fig. N5). The magmas erupted in a short period of time; the 3.5-kilometer (km)-thick basalt succession at Noril'sk-Talnakh was emplaced between $248.7 \pm 0.6$ and $250.3 \pm 1.1$ mega-annum (Ma) (Reichow and others, 2009). The flood basalts crop out on the Siberian craton, covering an area of approximately 2.5 million $\mathrm{km}^{2}$ (Fedorenko and others, 1996). In addition, flood basalts 


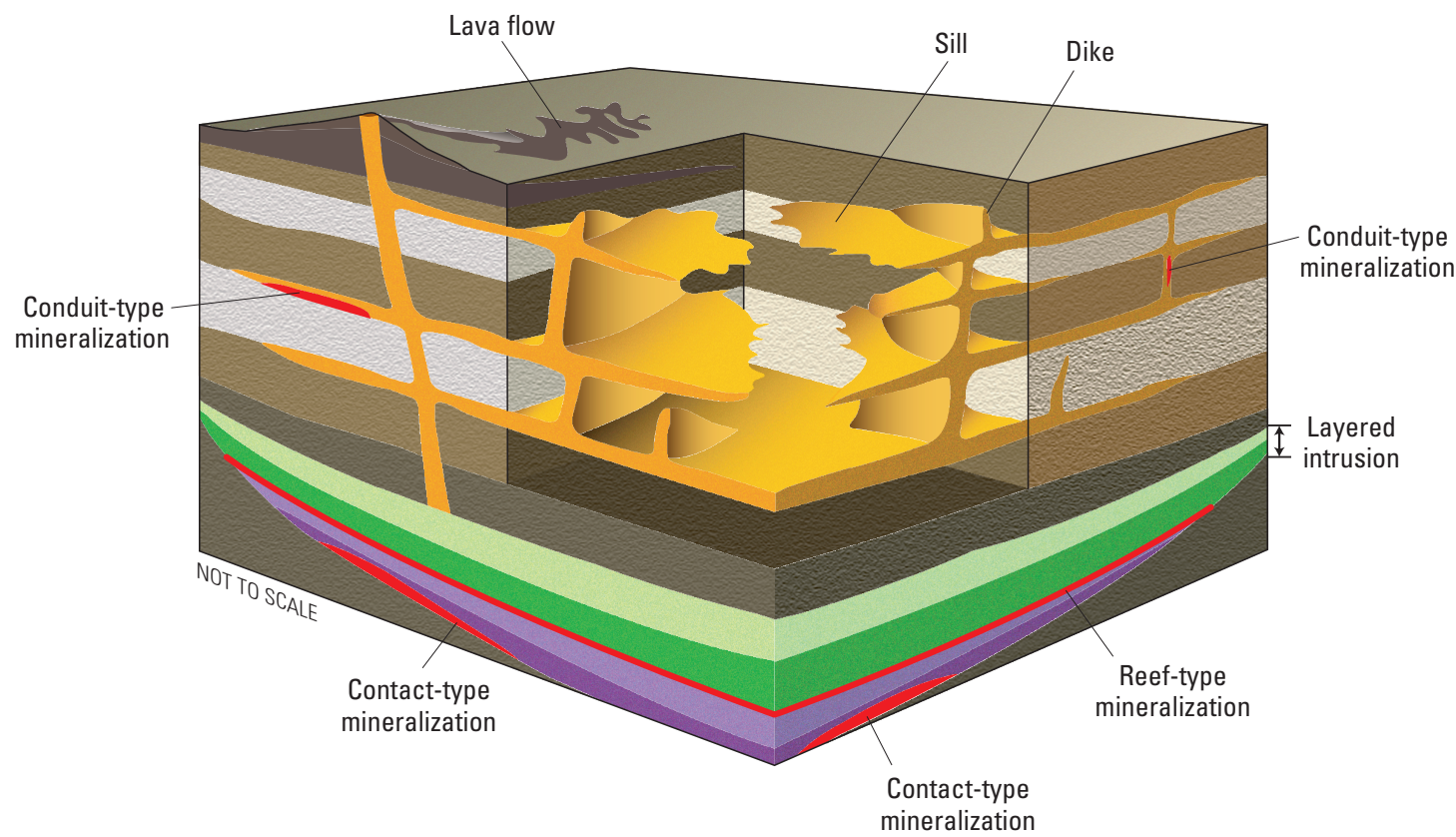

EXPLANATION

Magma or lava

Platinum-group element mineralization

Layered mafic to ultramafic intrusion

Figure N4. Schematic block diagram showing changes in the form of igneous intrusions with depth and the relative occurrence of conduit-type, contact-type, and reef-type magmatic ore deposits. Layered igneous rocks with reef-type and contact-type deposits occur at depth in large layered intrusions. Sills and dikes provide the conduits or pathways that magma follows as it rises upwards through the crust. Conduittype magmatic sulfide deposits can be localized in sills or dikes. Modified from Naus-Thijssen (2007).

are also found in the late Mesozoic fold and thrust belt in the Taimyr Peninsula and under the West Siberian Basin (Reichow and others, 2009).

A sill complex lies beneath the thick succession of volcanic flows and is exposed where the flood basalts have been removed by erosion (fig. N5). The sill complex consists of thousands of intrusions that delineate the pathways along which large volumes of magma were transported through the crust (Arndt, 2005). Sills with major nickel-copper-PGE deposits have been identified only in the Noril'sk-Talnakh area; however, copper-nickel sulfide occurrences in sills are distributed over a much larger area (fig. N5). All these occurrences of volcanic rocks and associated sills make up the Siberian Traps LIP (Ernst and Buchan, 2001).

In the Noril'sk-Talnakh area, plateaus covered by flood basalts have been dissected by erosion and exposed the underlying sill complex (fig. N6). More than 300 intrusions have been mapped, but only 33 contain elevated sulfide concentrations. Of these 33 intrusions, 16 contain relatively rich disseminated ore and only 4 contain rich massive sulfide orebodies (Diakov and others, 2002). High sulfur contents coupled with increasing $\delta^{34} \mathrm{~S}$ values is consistent with the addition of crustally derived ${ }^{34} \mathrm{~S}$-enriched sulfur to the magma of the ore-bearing intrusions (Grinenko, 1985; Li and others, 2003).

The ore-bearing intrusions have an elongate, finger-like shape; they may be up to $1 \mathrm{~km}$ wide by 500 meters $(\mathrm{m})$ thick and up to $15 \mathrm{~km}$ long. Most of the other sills form sheet-like bodies that are tens of meters thick. Rock textures of sills indicate crystallization and cooling at shallow depth. The orebearing intrusions are internally differentiated, with magnesium rocks and minerals concentrated towards the base of the sills; the laterally continuous sills show less internal differentiation. 


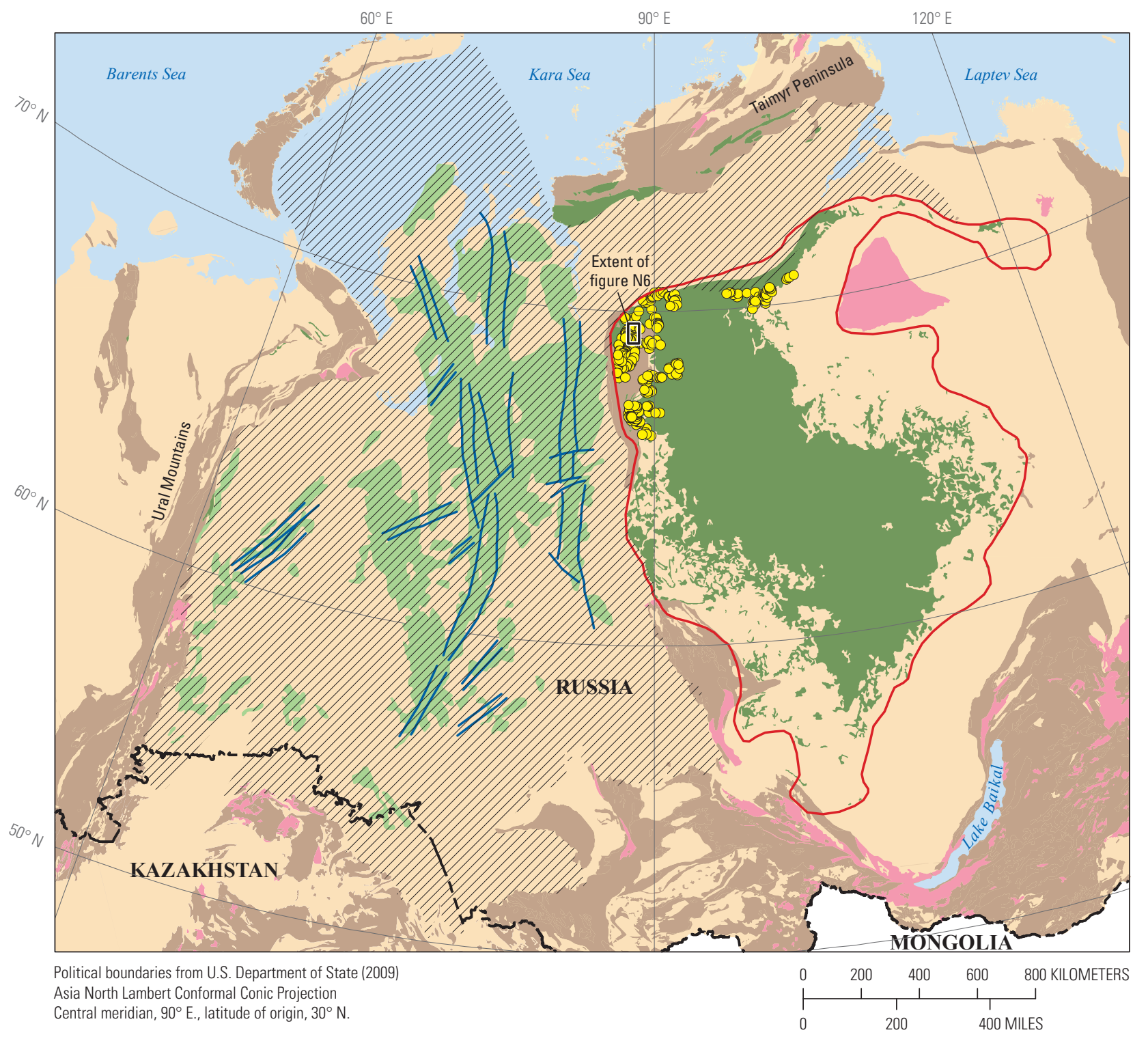

EXPLANATION

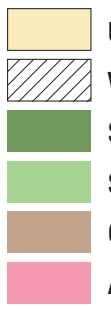

Undeformed cover of sedimentary rocks
West Siberian Basin
Siberian flood basalts, exposed
Siberian flood basalts, covered
Orogenic belts

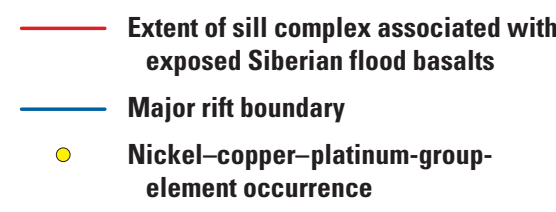

Figure N5. Map showing the geology of the Siberian flood basalt province in Russia, which is the largest flood basalt province in the world. The province includes a large area of exposed lavas and sills. It also includes an equally large area of lavas that are covered by younger deposits that make up the West Siberian Basin. The sill complex associated with the exposed lavas underlies and extends beyond the area of lavas. The deposits of the Noril'sk-Talnakh area, along with many occurrences of magmatic sulfide mineralization, have been found in the northwestern part of the province where the lavas and sills are exposed. Map includes information from Zonenshain and others (1988), Fugro Robertson, Ltd. (2008), and Reichow and others (2009). 


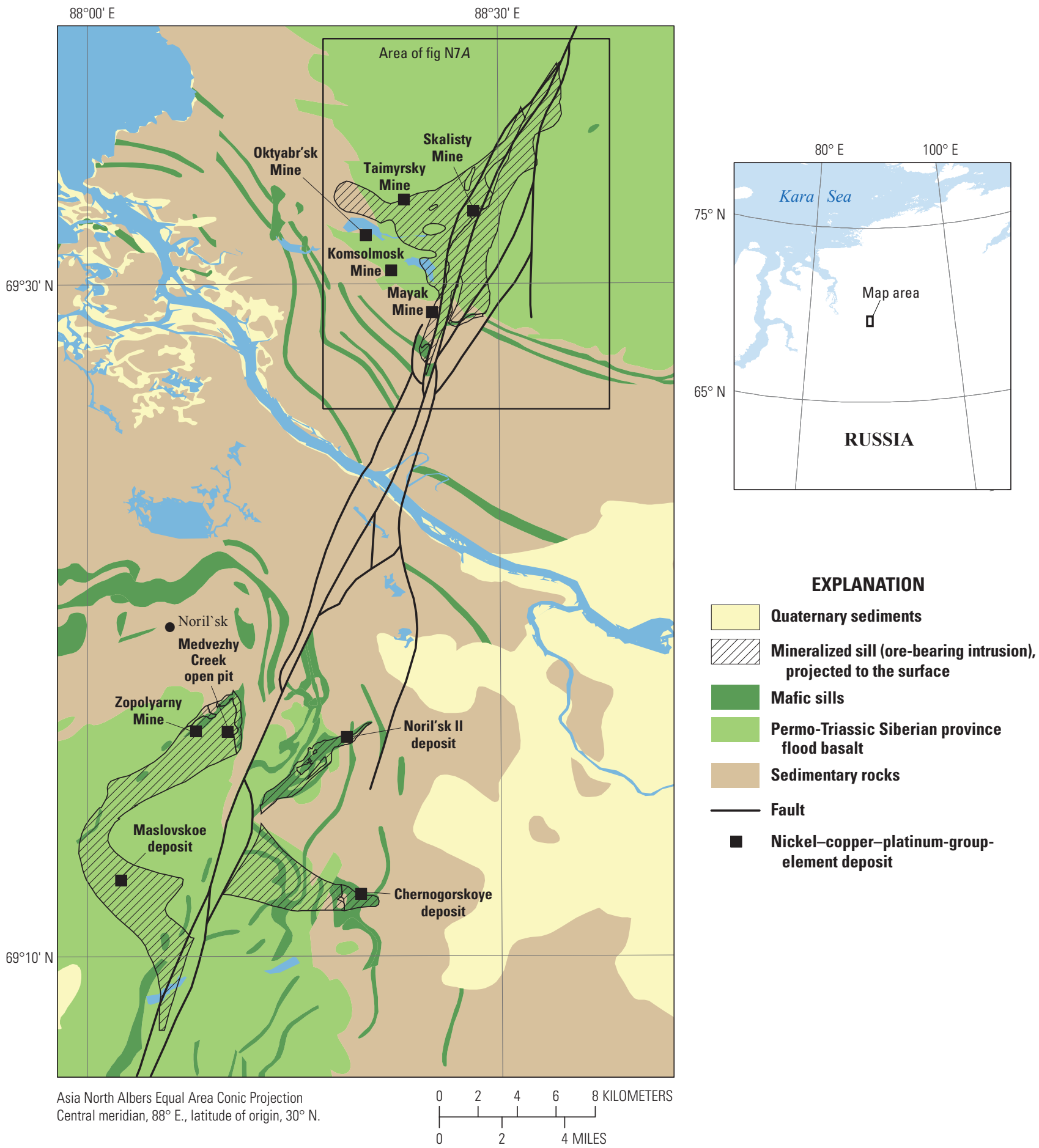

Figure N6. Map showing the geology of the Noril'sk-Talnakh area and the location of nickel-copper-platinum-groupelement (Ni-Cu-PGE) deposits. Flood basalts crop out in the northeast and the southeast; in other areas, erosion has removed the lavas and exposed the underlying sills that intrude older sedimentary rocks. The mineralized sills largely underlie the lavas. Their subsurface extent has been projected to the surface. Geology simplified from Sherman and others (1991). 


\section{N12 Critical Mineral Resources of the United States-Platinum-Group Elements}

The amount of massive sulfide ores associated with the mineralized intrusions at Talnakh is astounding. The massive sulfide ores, which are up to $45 \mathrm{~m}$ thick, underlie most of the intrusions in the Talnakh area (fig. N7A; Kunilov, 1994). The ore-bearing sills contain, or are associated with, concentrations of sulfide minerals that exceed the amount of sulfur that could have been dissolved in the volume of magma now in the sills. The sulfide mineralization also contains high concentrations of PGEs, indicating a silicate-to-sulfide ratio that is larger than the observed proportion of silicate minerals to sulfide minerals in the sills. This suggests that at the time of ore formation, the sulfide liquids equilibrated with a much larger volume of magma than is now represented by the igneous rocks in the sill. Field relations indicate lateral movement of immiscible sulfide liquids during and after solidification of the silicate igneous rocks.

In the Talnakh area, fractional crystallization of the immiscible sulfide liquids formed mineralogically and compositionally zoned orebodies (fig. N7 B). Massive ores formed by early crystallization of sulfides contain less copper and PGEs than ores that formed from sulfide liquid that are the end product of the fractional crystallization process (fig. N8). The copper- and PGE-rich late-stage ores are the likely source of most of the PGE production from the Talnakh deposits (fig. N7C). Between 1960 and 2011, Russia (including all the Soviet Union until 1991) produced about 5,000 metric tons of PGEs, most of them from the Noril'sk-Talnakh area (U.S. Bureau of Mines, 1933-96; U.S. Geological Survey, 1997-2016). Mining depths in the Noril'sk-Talnakh area range from 300 to $1,500 \mathrm{~m}$ (Kunilov, 1994).

\section{Reef-Type and Contact-Type Deposits}

LIP-related layered mafic to ultramafic intrusions contain most of the world's resources of PGEs. Layered intrusions form by crystallization of magma deep in Earth's crust and have sheet-like to dike-like shapes. They consist primarily of cumulates, which are rocks that represent accumulations (concentrations) of minerals that crystallize from magmas. Cumulus rock textures are distinctive, as they record nucleation and growth of crystals from the melt, enlargement of crystals to form a touching framework (a crystal mesh), solidification, and subsolidus grain boundary adjustments that minimize grain boundary surface energies (Hunter, 1987).

Cumulus rocks are also distinctive in that they do not have the composition of naturally occurring magmas but are instead a mixture of early formed crystals with variable proportions of trapped liquid.

As the magma crystallizes in these intrusions, layering features develop that are recognized by the variations in the modal proportions of the minerals, the rock textures, the grain size, and the mineral compositions. Individual layers range from laminations formed by the orientation of individual crystals that are millimeters in diameter to strata that are tens to hundreds of meters thick and may extend for hundreds of kilometers along strike. The layering features are so pronounced and consistent that stratigraphic principles developed for sedimentary rocks are applied to these igneous rocks. Stratigraphic columns are measured through the sequence of layered igneous rocks to define mappable units; the thickness of the layered rocks in intrusions ranges from hundreds of meters to as much as $10 \mathrm{~km}$.

Layered intrusions have two significant styles of magmatic sulfide mineralization - reef type and contact type. The analogy with sedimentary rocks extends to the terminology used for magmatic deposits in layered intrusions. Some of the magmatic deposits are strata-bound, which means that the deposit is confined to a stratigraphic unit, not to a particular bed. Other magmatic deposits are stratiform, which means that the deposit constitutes one or more of the igneous layers; an example would be the chromium deposits in layered intrusions (which correspond to igneous rock layers that are composed primarily of the mineral chromite). Reef-type and contact-type deposits are strata-bound, as described below.

Reef-type PGE deposits are disseminated copper-, iron-, nickel-, and PGE-bearing minerals that are associated with one or more strata within a layered igneous intrusion (fig. N4). The mineralized rock unit almost always contains disseminated magmatic sulfide minerals, but the rock layers are dominated by silicate minerals or oxide minerals such as chromite or magnetite. The modal abundance of sulfide minerals is usually much less than a few percent. The term "reef" is an Australian and South African mining term for a relatively flat-lying, tabular orebody. Within a layered igneous intrusion, reef-type mineralization is laterally persistent, extending for the strike length of the intrusion, which is typically tens to hundreds of kilometers. The mineralized interval is thin (generally centimeters to meters thick), however, relative to the total stratigraphic thickness of the layers in the intrusion, which can vary from hundreds to thousands of meters.

Copper-nickel-PGE contact-type deposits consist of disseminated magmatic sulfide minerals found near the lower contact or margin of mafic to ultramafic layered intrusions (fig. N4). The host rocks for the disseminated sulfide minerals are the igneous rocks of the intrusion and adjacent contact metamorphosed country rocks. Some igneous lithologies are cumulates, but other mineralized mafic and ultramafic igneous rocks are texturally and lithologically heterogeneous, exhibiting changes in texture and mineral proportions at scales of from centimeters to meters. Textures indicative of chilling or unidirectional growth of silicate minerals may also be present. Inclusions of autoliths and xenoliths are common; they are surrounded by igneous rocks that have textural, mineralogical, and isotopic features suggestive of reaction with the inclusions (Iljina and Lee, 2005). 

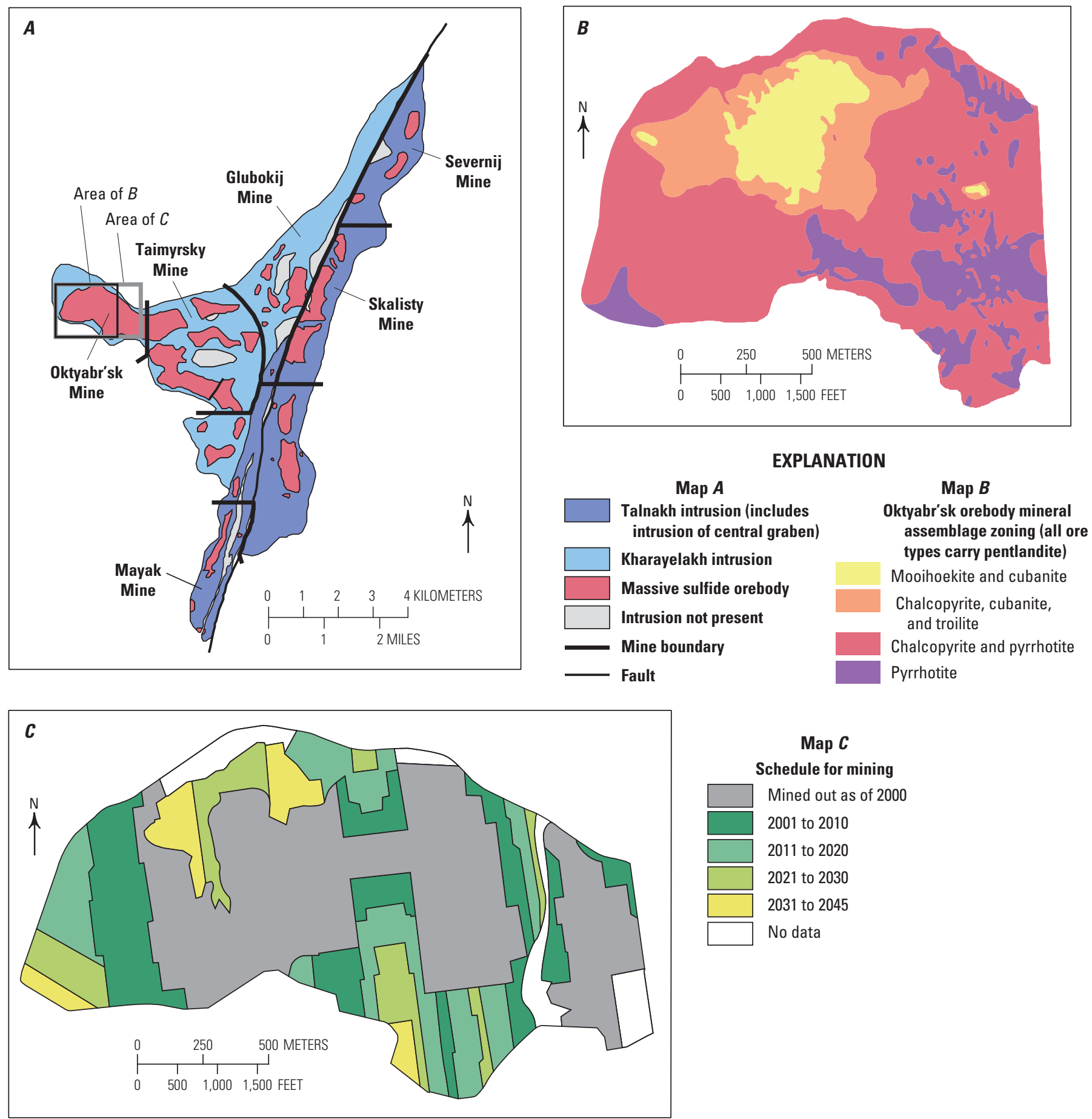

Map C

Schedule for mining

Mined out as of 2000

2001 to 2010

2011 to 2020

2021 to 2030

2031 to 2045

No data

Figure N7. Maps showing nickel-copper-platinum-group-element (Ni-Cu-PGE) deposits in the Talnakh area, Russia. $A$, Extent of two elongate sill-like intrusions (Talnakh and Kharayelakh) and the distribution of massive sulfide ores that underlie them. $B$, Zoning of sulfide minerals in the Oktyabr'sk orebody. The concentric pattern of minerals formed by fractional crystallization of immiscible sulfide melt; the pyrrhotite $\left(\mathrm{Fe}_{1-x} \mathrm{~S}\right)$ assemblage solidified first, and mooihoekite $\left(\mathrm{Cu}_{9} \mathrm{Fe}_{9} \mathrm{~S}_{16}\right)$ and cubanite $\left(\mathrm{CuFe}_{2} \mathrm{~S}_{3}\right)$ solidified last. The copper-rich ore assemblages contain the most PGEs. C, Mined-out areas of the Oktyabr'sk orebody and future mine plans to 2045. Most of the copper- and PGE-rich ores have been mined. Maps modified from Zientek and others (1994) and Naldrett (2006). 
Figure N8. Photograph of copper-rich massive sulfide ore exposed in a stope in the Oktyabr'sk Mine in the Talnakh area, Russia. The ore consists of several iron-copper-sulfide minerals, such as chalcopyrite $\left(\mathrm{CuFeS}_{2}\right)$, mooihoekite $\left(\mathrm{Cu}_{9} \mathrm{Fe}_{9} \mathrm{~S}_{16}\right)$, and talnakhite $\left(\mathrm{Cu}_{9}\left(\mathrm{Fe}, \mathrm{Ni}_{8}\right)_{16}\right)$. The minerals are brassy to golden yellow, but some develop iridescent blue and maroon colors when exposed to air. These ores represent the end product of the fractional crystallization of immiscible sulfide liquid and can contain tens to hundreds of parts per million platinum-group elements. Photograph by Michael L. Zientek, 1992.

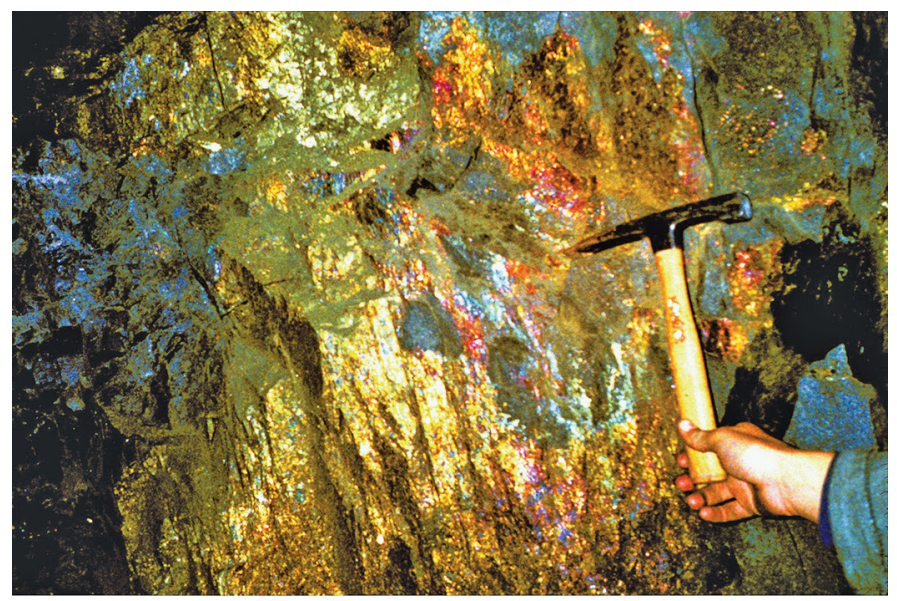

Sulfide abundance in contact-type PGE deposits is typically about 3 to 5 volume percent, although some nettextured and (or) massive sulfide ores may be present. Erratic variation in the distribution of sulfide minerals is typical, although the concentration of sulfide minerals within the intrusion generally increases towards the contact with adjacent country rocks. The mineralization can be laterally persistent, commonly extending for the entire strike length of the layered igneous intrusion. The interval that can contain magmatic sulfide minerals is generally tens to hundreds of meters in thickness, however. The proportion of sulfide minerals varies within the rock layers that can host ore; during exploration and development, economic cutoff grades are used to define the volume of rock within the igneous rock unit that could be mined. Therefore, low-grade mineralization may occur outside the cutoff limit that defines minable parts of deposits. Examples of major reef-type (a-c) and contact-type (a and d) deposits are discussed below.

(a) Merensky Reef, UG2 Chromitite, and Platreef, Bushveld Complex, South Africa. The Paleoproterozoic Bushveld Complex (2,054.4 $\pm 1.3 \mathrm{Ma}$, using the uraniumlead-zircon technique for determining age) is a large mass of igneous rock that underlies an area of approximately $69,000 \mathrm{~km}^{2}$ in South Africa (fig. N9; Hall, 1932; von Gruenewaldt, 1977; Scoates and Friedman, 2008). It is part of the Bushveld LIP (Ernst and Buchan, 2001), which also includes the Molopo Farms Complex (another large layered mafic to ultramafic intrusion in Botswana and South Africa (Prendergast, 2012); a large complex of sills related to the Bushveld Complex (Sharpe, 1981; Sharpe and Hulbert, 1985); and the Dullstroom basalts in South Africa (Buchanan and others, 1999).

The Bushveld Complex consists of several igneous suites. The most important economically is the Rustenburg Layered Suite, which is an approximately 8 -km-thick layered sequence of mafic to ultramafic cumulates (Vermaak and von Gruenewaldt, 1986; Walraven, 1986) that contain world-class deposits of chromium, PGEs, and titanium-vanadium. The cumulates of the Rustenburg Layered Suite are exposed intermittently around the periphery of the Bushveld Complex in areas referred to as limbs. Igneous layering dips gently towards the center of the Bushveld Complex. Seismic surveys trace igneous units exposed at the surface to depths exceeding $6 \mathrm{~km}$ (Sargeant, 2001; Campbell, 2011). Gravity modeling indicates that the western and eastern limbs of the Bushveld Complex are connected at depth (fig. N9, cross section $A-A$ '; Webb and others, 2004).

Two PGE-enriched reefs, the UG2 Chromitite (fig. N10) and the Merensky Reef (fig. N11; Viljoen, 1999), each occur near the base of different repetitive rock sequences (cyclic units) and can be continuously traced onstrike for the full extent of the eastern and western limbs of the complex. The grade of the UG2 Chromitite deposit is about 5 grams per metric ton $(\mathrm{g} / \mathrm{t})$ PGEs and gold; the grade of the Merensky Reef is about $6 \mathrm{~g} / \mathrm{t}$ in the western part of the complex and about $4.2 \mathrm{~g} / \mathrm{t}$ in the eastern part.

In the northern limb, varitextured pyroxenite, norite, and gabbro are found near the lower contact of the complex with metasedimentary rocks of the Transvaal Supergroup (van der Merwe, 1976). These igneous rocks host the Bushveld Complex's contact-type copper-nickel-PGE deposits (known as the Platreef). The combined PGE and gold grades for the Platreef deposits range from 0.55 to $3.7 \mathrm{~g} / \mathrm{t}$. Since the 1920 s, mining has recovered 7,200 metric tons of PGEs from the Bushveld Complex (U.S. Bureau of Mines, 1933-34; 1933-96; U.S. Geological Survey, 1997-2016).

(b) Main Sulphide Zone, Great Dyke, Zimbabwe. The Neoarchean Great Dyke (2575.4 $\pm 0.7 \mathrm{Ma}$, age determined from zircon using uranium-lead technique; Oberthür and others, 2002 ) is a long (about $550 \mathrm{~km}$ ) and narrow (about $11 \mathrm{~km}$ ) layered igneous intrusion in Zimbabwe. This intrusion and some subparallel dikes are the geologic features associated with the Great Dyke of Zimbabwe LIP (Ernst and Buchan, 2001). The rock types of the Great Dyke consist of layered mafic to ultramafic cumulates that dip inwards from the sides towards the center of the intrusion (fig. N12). Since the 1980s, mining has recovered 107 metric tons of PGEs from a reeftype PGE deposit within the Great Dyke- the Main Sulphide Zone-which occurs 10 to $50 \mathrm{~m}$ below the contact between the ultramafic and mafic sequences. The Main Sulphide Zone is typically 2 to $3 \mathrm{~m}$ thick, and the grade of the deposit varies from about 3.5 to $4 \mathrm{~g} / \mathrm{t}$ PGEs and gold (U.S. Bureau of Mines, 1933-96; Wilson, 1996; U.S. Geological Survey, 1997-2016; Wilson and Prendergast, 2001). 

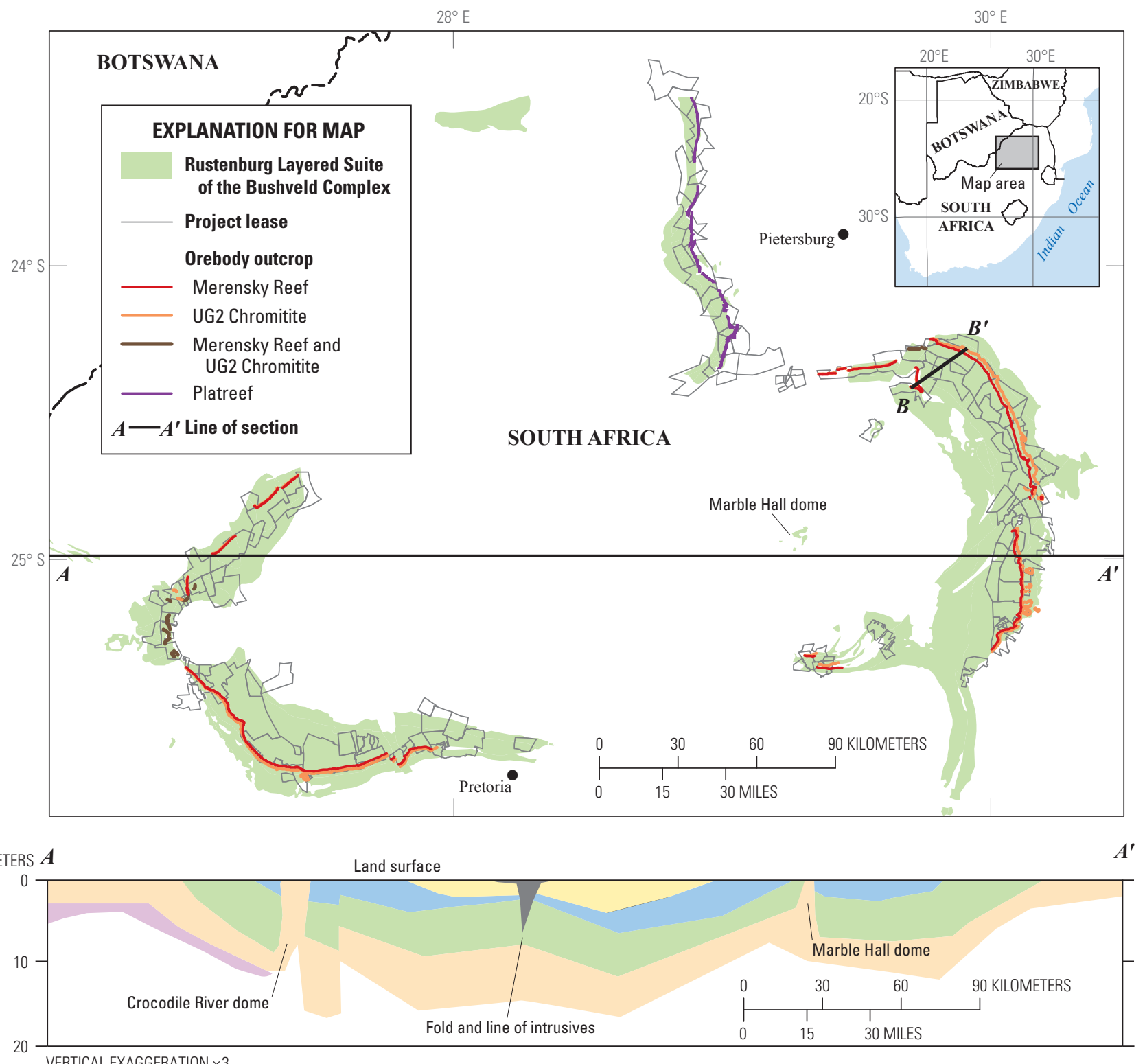

VERTICAL EXAGGERATION $\times 3$

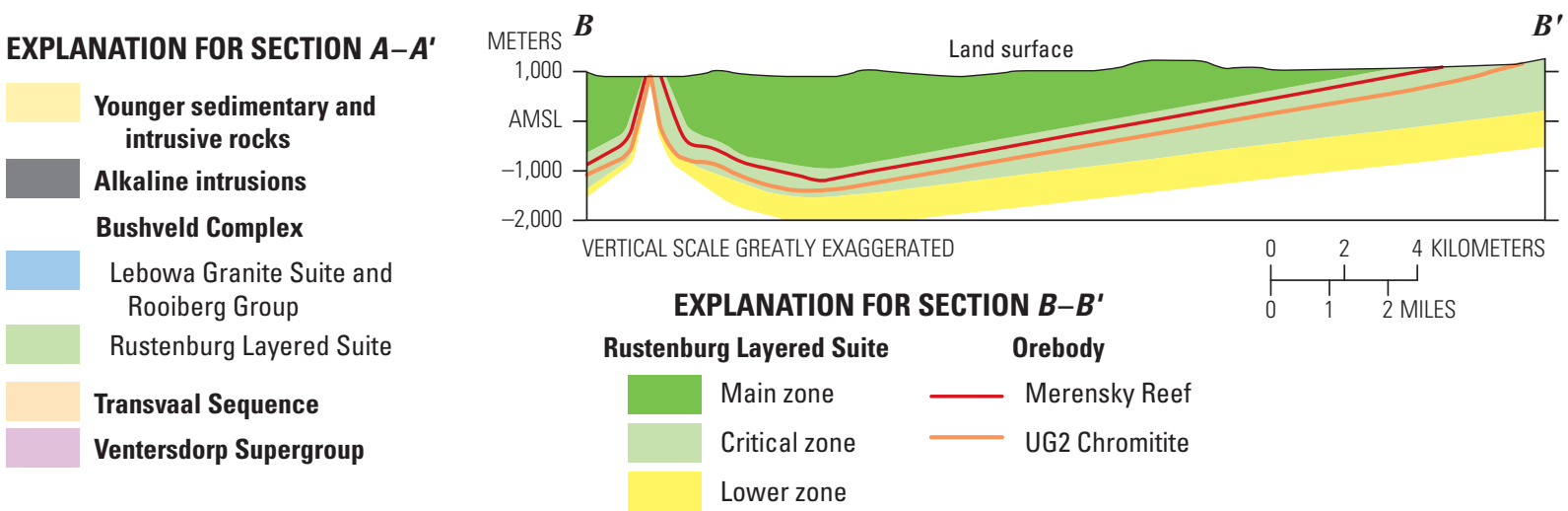

Figure N9. Map showing the Rustenburg Layered Suite of the Bushveld Complex, South Africa, the surface trace of significant orebodies, and cross sections through the central area and northeastern limb. Cross section $A-A^{\prime}$ is based on geophysical modeling and suggests that the mafic and ultramafic rocks that make up the eastern and western portion of the complex are connected at depth. Modified from Webb and others (2004). Cross section $B-B^{\prime}$ shows the remarkable continuity of the layers that host the Merensky Reef and UG2 Chromitite platinum-group-element deposits. Modified from Bauba Platinum (2012). Rustenburg Layered Suite is derived from Martini and others (2001); project leases and orebodies are from Zientek and others (2014). 
Figure N10. Photograph of the UG2 Chromitite at the Karee Mine in the western part of the Bushveld Complex, South Africa. The black layer at the base of the exposure is the main layer of the UG2 Chromitite. It has an undulating contact with the underlying, light-colored anorthosite layer. Several thin chromitite seams overlie the main chromitite layer. Most of the exposed rock is brown pyroxenite associated with the UG2 cyclic unit; a sharp contact separates the pyroxenite layer from the overlying light-colored anorthosite layer. Photograph by Wolfgang Maier, University of Cardiff, Wales, United Kingdom.

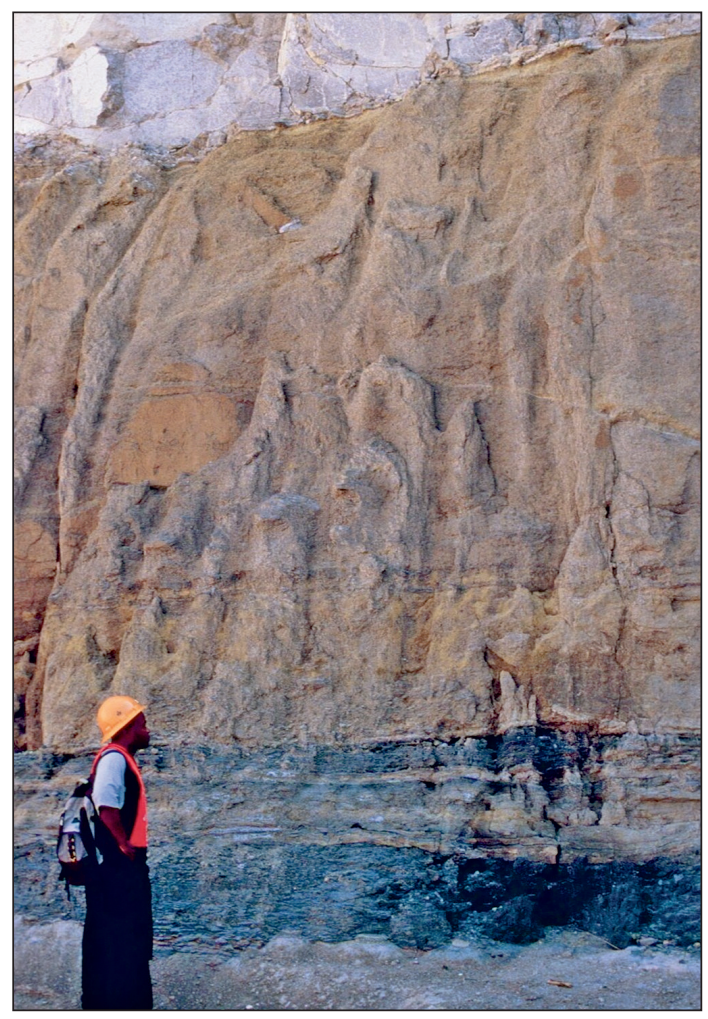

A

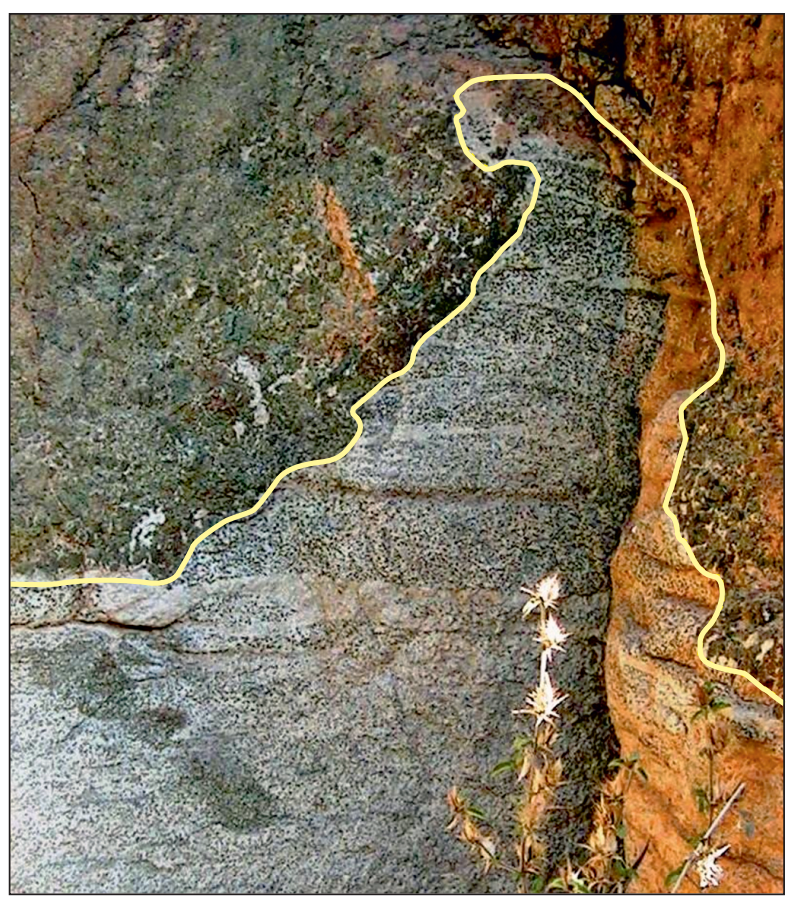

B

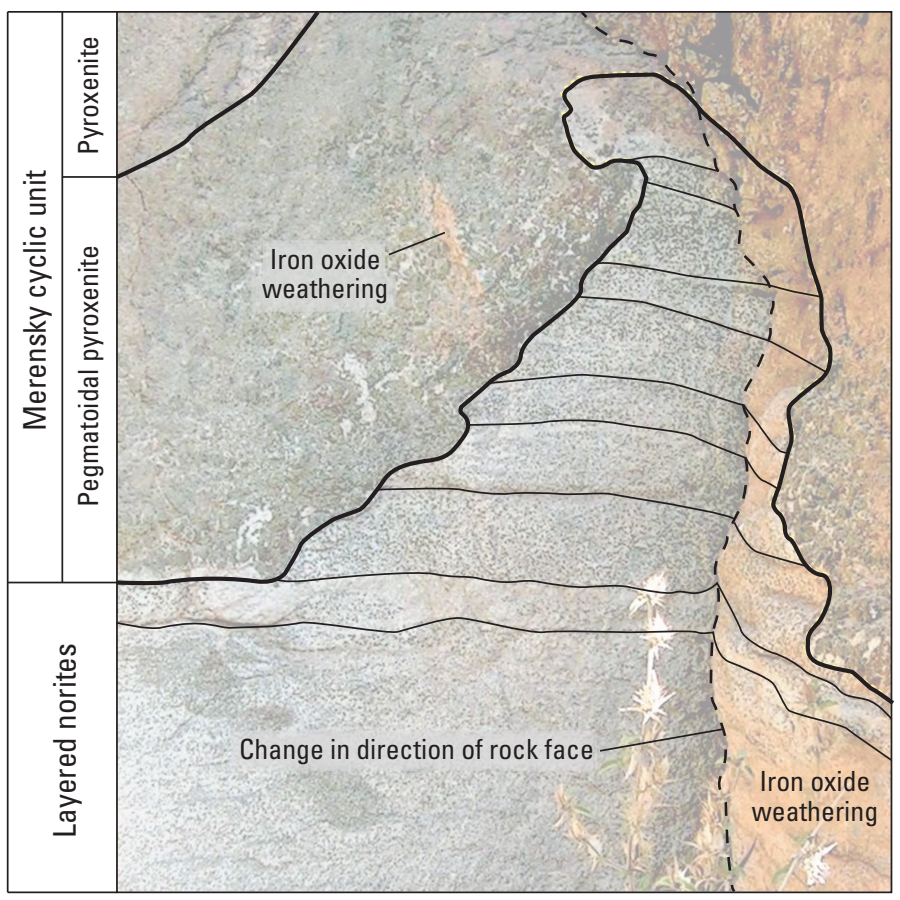

Figure N11. The base of the Merensky cyclic unit, a pegmatoidal pyroxenite, which contains the platinum-group-element-rich Merensky Reef. $A$, Photograph of the base of the Merensky cyclic unit on the Hackney farm property in the eastern part of the Bushveld Complex, South Africa. The basal contact of the cyclic unit is annotated by the yellow line. $B$, Same photograph with an overlay showing major features, including the dark, pegmatoidal pyroxenite cutting layering in the underlying lighter-colored norites. Photograph by Wolfgang Maier, University of Cardiff, Wales, United Kingdom. 

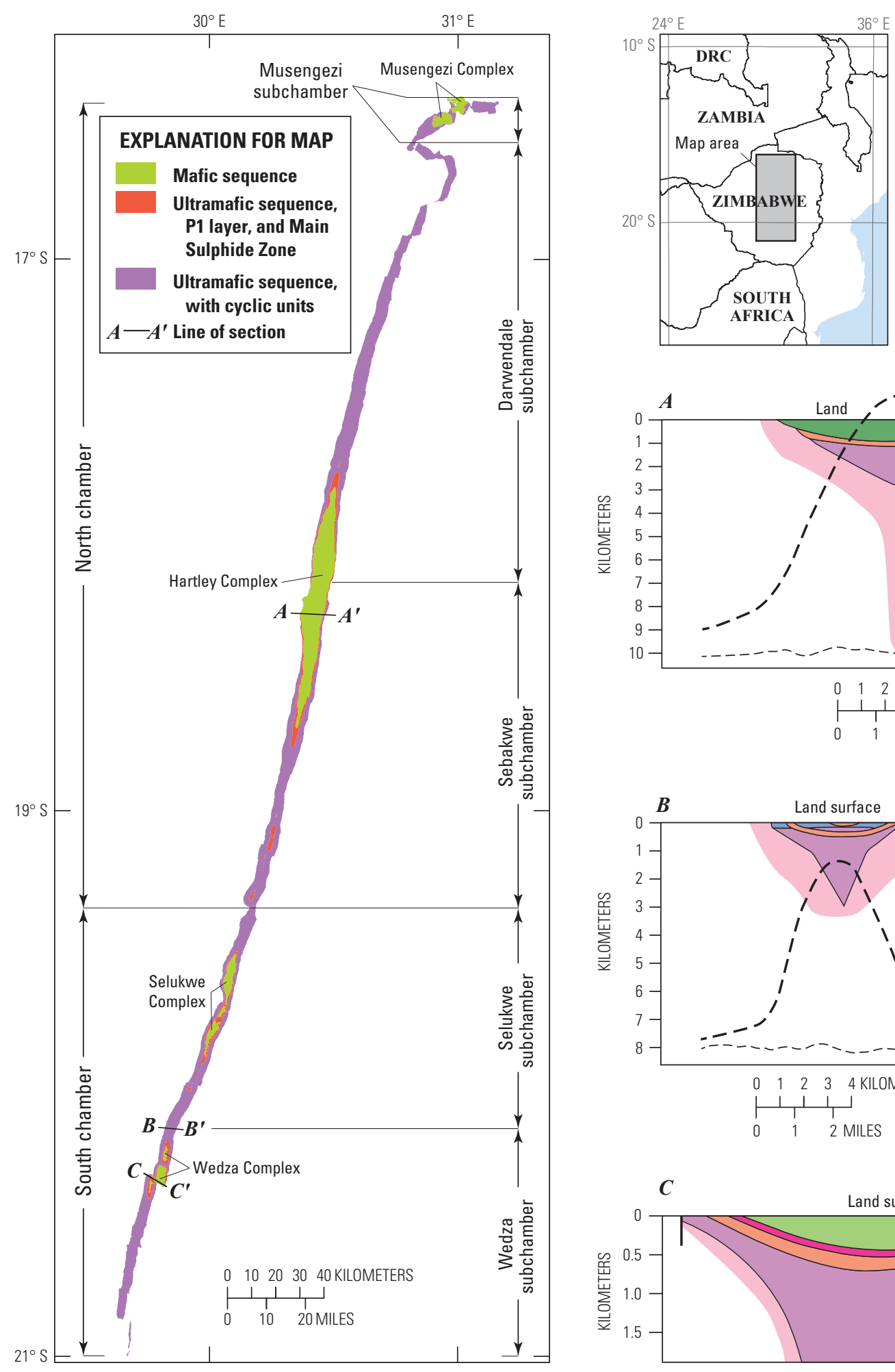

EXPLANATION FOR CROSS SECTIONS
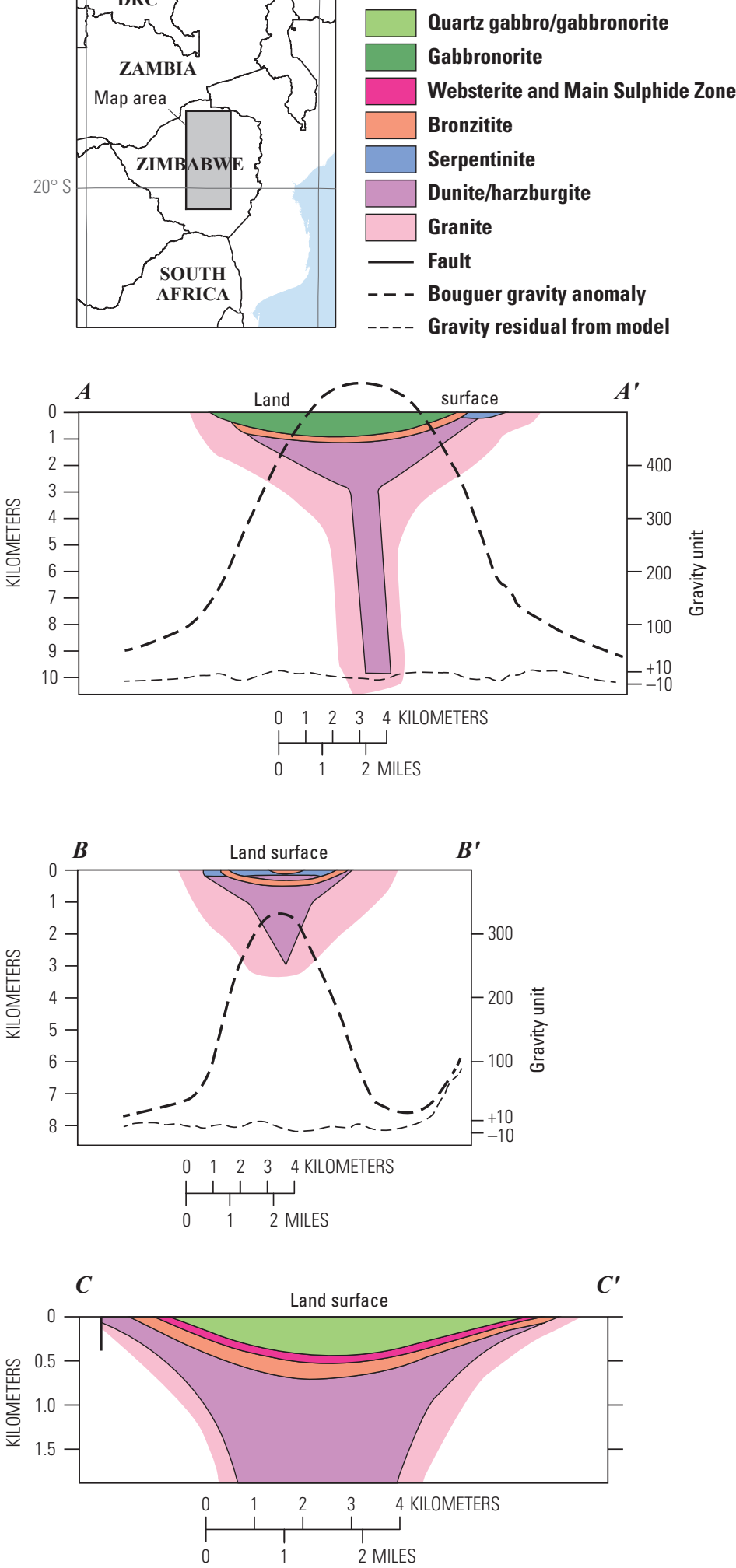

Figure N12. Geologic map and cross sections of the Great Dyke, Zimbabwe. Geologic mapping and geophysical studies show that the intrusion has a dike-like form; however, igneous layering dips gently into the center of the intrusion. The Main Sulphide Zone, which is a reef-type platinum-group-element deposit, is confined to the P1 layer of the ultramafic sequence (as shown on the map) and to the corresponding websterite layer shown on cross section $C-C^{\prime}$. Geologic map generalized from Worst (1957); geologic sections generalized from Podmore and Wilson (1987). 
(c) J-M Reef, Stillwater Complex, Montana. The Neoarchean Stillwater Complex (2,704 $\pm 5 \mathrm{Ma}$, using the uranium-lead zircon technique for determining age; Premo and others, 1990) is a mafic to ultramafic layered intrusion exposed in south-central Montana (fig. N13; Zientek and others, 2002). This intrusion is the only feature associated with the Stillwater LIP (Ernst and Buchan, 2001). More than 5,500 $\mathrm{m}$ of layered rocks are exposed, which can be traced for $48 \mathrm{~km}$ along strike. The J-M Reef, which is a reef-type PGE deposit, consists of 0.5 to 3 volume percent magmatic sulfide minerals that are associated with a distinctive olivine-bearing cyclic unit that can be mapped both on the surface and underground. The actual distribution of sulfide minerals within the cyclic unit is determined by detailed mapping, drilling, and sampling, however. The J-M Reef, which is open at depth, has been traced for $42 \mathrm{~km}$ of the $48-\mathrm{km}$ strike length of the complex and at least $2 \mathrm{~km}$ down the dip of layering. The J-M Reef is currently the sole source of primary PGE production and reserves in the United States. Since 1986, the Stillwater and East Boulder Mines (fig. N14) have produced roughly 305 metric tons of PGEs from the J-M Reef deposit. The overall deposit grade is about $15 \mathrm{~g} / \mathrm{t}$ palladium and platinum (U.S. Bureau of Mines, 1933-96; U.S. Geological Survey, 1997-2016; Abbott and others, 2011).

(d) Contact-Type Deposits, Duluth Complex, Minnesota. The Keweenawan LIP resulted from the eruption of lavas and emplacement of igneous intrusions between 1,109 and 1,087 Ma along a linear belt where Earth's crust subsided (the Midcontinent Rift). The rift extends for more than 2,500 km from Kansas northward beneath Lake Superior and then southeast through Michigan (fig. N15); however, exposures of rocks related to the rift are found only in the Lake Superior region. Igneous rocks associated with this LIP cover more than $160,000 \mathrm{~km}^{2}$ (Ernst and Buchan, 2001). LIP and rift-related igneous rocks exposed in the Lake Superior region include flood basalts, mafic intrusions, and minor rhyolite lava flows. The Mesoproterozoic Duluth Complex in Minnesota is composed of several discrete intrusions formed from mafic to felsic magmas that were emplaced between 1,108 and 1,098 Ma into older rocks, which include Paleoproterozoic sedimentary rocks and Archean granite-greenstone terranes (Peterson and Severson, 2002), and coeval LIP and rift-related flood basalts and hypabyssal (subvolcanic) intrusions.

Contact-type mineralization that includes a few percent sulfide minerals is laterally extensive along the base of some of the intrusions (mainly the South Kawishiwi and the Partridge River intrusions) along the western margin of the Duluth Complex. The mineralized interval of igneous rocks along the contact varies from tens to hundreds of meters in thickness. Mineral exploration studies since the early 1950s indicate that about 4 billion metric tons of mineralized rock containing 0.6 weight percent copper, 0.2 weight percent nickel, and $0.655 \mathrm{~g} / \mathrm{t}$ PGEs may be present (Listerud and Meineke, 1977; Naldrett, 2010b). Because the proportion of sulfide minerals varies along strike, economic cutoff grades are used to define deposits along the contact zone.

\section{Hydrothermal and Sedimentary Deposits}

Anomalous concentrations of PGEs or the presence of platinum-group minerals have been reported in a variety of hydrothermal and sedimentary deposit types (table N2 at back of chapter; Wilde and others, 2003; Wilde, 2005). Hydrothermal mineral deposits form by the interaction of hot water and rock. Water is a good solvent and hot water, called hydrothermal fluid, can efficiently move and deposit materials that occur in some mineral deposits. Sedimentary mineral deposits are economic concentrations of minerals in sedimentary rocks that formed directly from water in oceans, lakes, or in underground reservoirs. Although their occurrence is tantalizing, "a world-class deposit in which the PGE[s] are primary commodities and hydrothermal [processes] were indisputably the primary mechanism of concentration is yet to be discovered" (Wood, 2002, p. 233). Nevertheless, economic deposits of hydrothermal platinum and palladium may exist (Wilde and others, 2003).

Experimental and theoretical investigations by many authors have helped to identify the constraints under which the PGEs can be mobilized by fluids at relatively low temperatures (that is, at approximately $300{ }^{\circ} \mathrm{C}$ or less) (Wood and others, 1992; Gammons and Bloom, 1993; Wood, 2002; Hanley, 2005; Colombo and others 2008; Barnes and Liu, 2012; and references cited therein). Significant concentrations of platinum and palladium can dissolve into solution as chloride complexes only under highly oxidizing or highly acidic conditions. Palladium and platinum can be transported as bisulfide complexes in acidic to neutral solutions under reduced and moderate oxidation conditions. Hydroxide, thiosulfate, and organic complexes may be the dominant forms of dissolved platinum and palladium in low-temperature, near-surface environments.

Chloride complexes play a significant role in the mass transfer of PGEs in (a) porphyry copper deposits, especially the porphyry copper-gold subtype with island arc affinities and those associated with alkaline igneous rocks; (b) unconformity-related uranium-gold-platinumpalladium deposits; and (c) sediment-hosted strata-bound copper deposits (Wood, 2002). Bisulfide complexes may be responsible for (a) transporting platinum, palladium, and gold in the footwall copper-nickel-PGE ores at Sudbury, Ontario, and in nickel-molybdenum-PGE-gold enriched black shale deposits; (b) the remobilization of PGEs or recrystallization of platinum-group minerals in ophiolites and other ultramafic rocks during serpentinization and metamorphism; and (c) the remobilization of PGEs from mineralization of primary magmatic origin by deuteric or hydrothermal processes (Wood, 2002).

Manganese crusts that precipitate on the sides of seamounts are the definitive example of a sedimentary deposit enriched in PGEs (table N2). These crusts take millions of years to accumulate; the metals are extracted from seawater by adsorption processes (Halbach and others, 1989). 


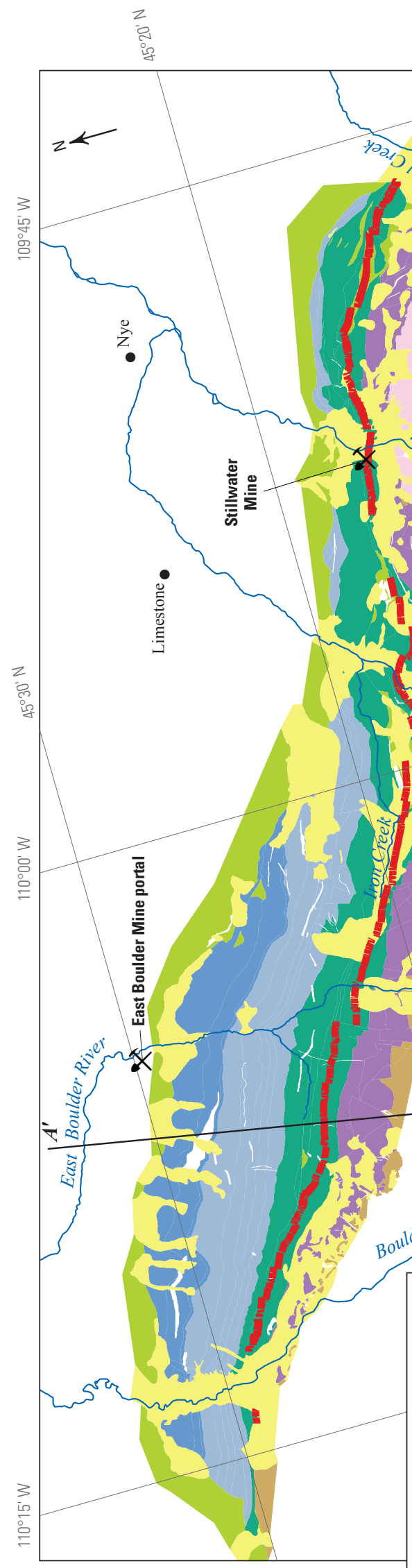

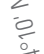
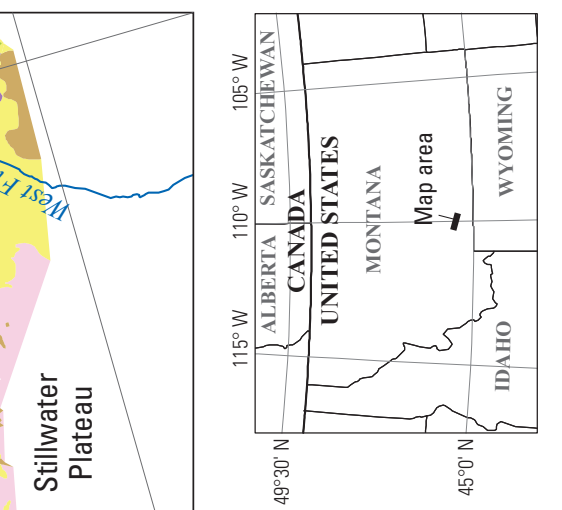

it

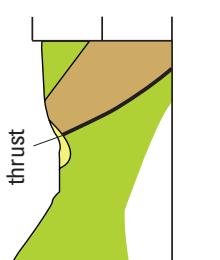

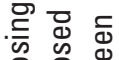

응

× 㐅⿸

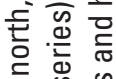

舟

o 음

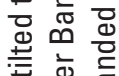

产要

递 잉

证

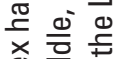

을 를

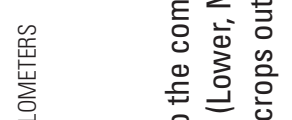

这

崖岕竞通

마-일

䒿

- -

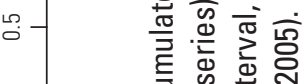

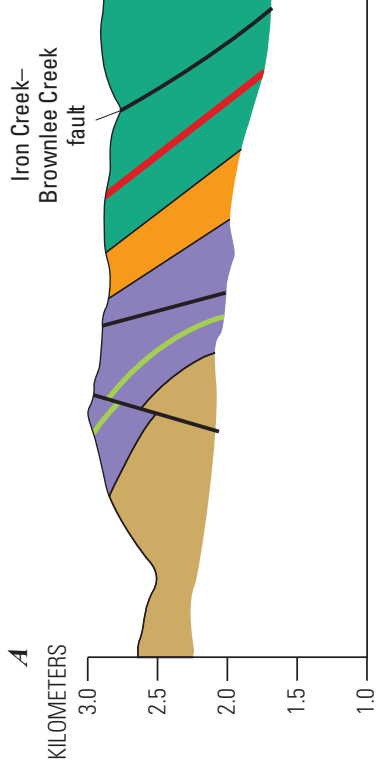

$\circ \perp$

可

에

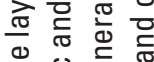

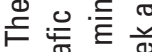

வ

政

들 흥 은

$\sum_{\substack{0 \\ 0}} \frac{1}{3}$

징응

을. 올 点

范产

离 兽 恶

芜包它

क

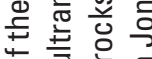

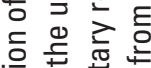

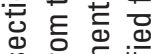

क

施

o 'क 늠

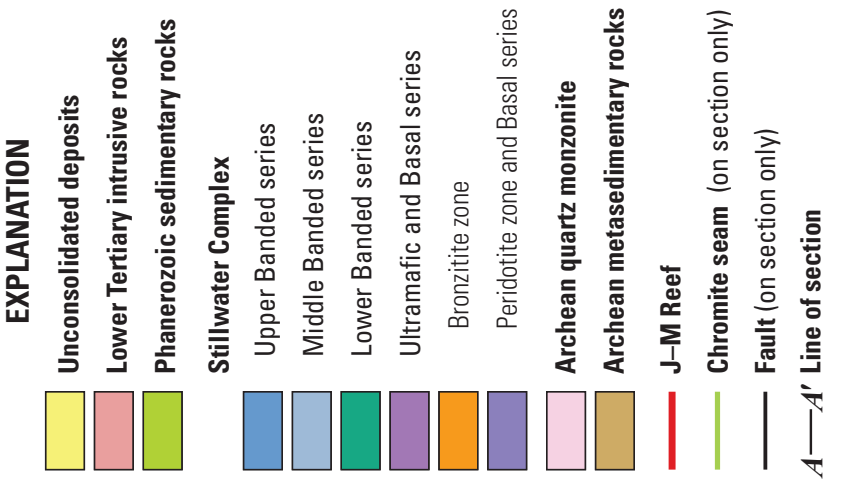

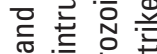

은.

ह

읗

음

임등 흥 음

ำ ํㅏㄹ

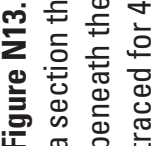




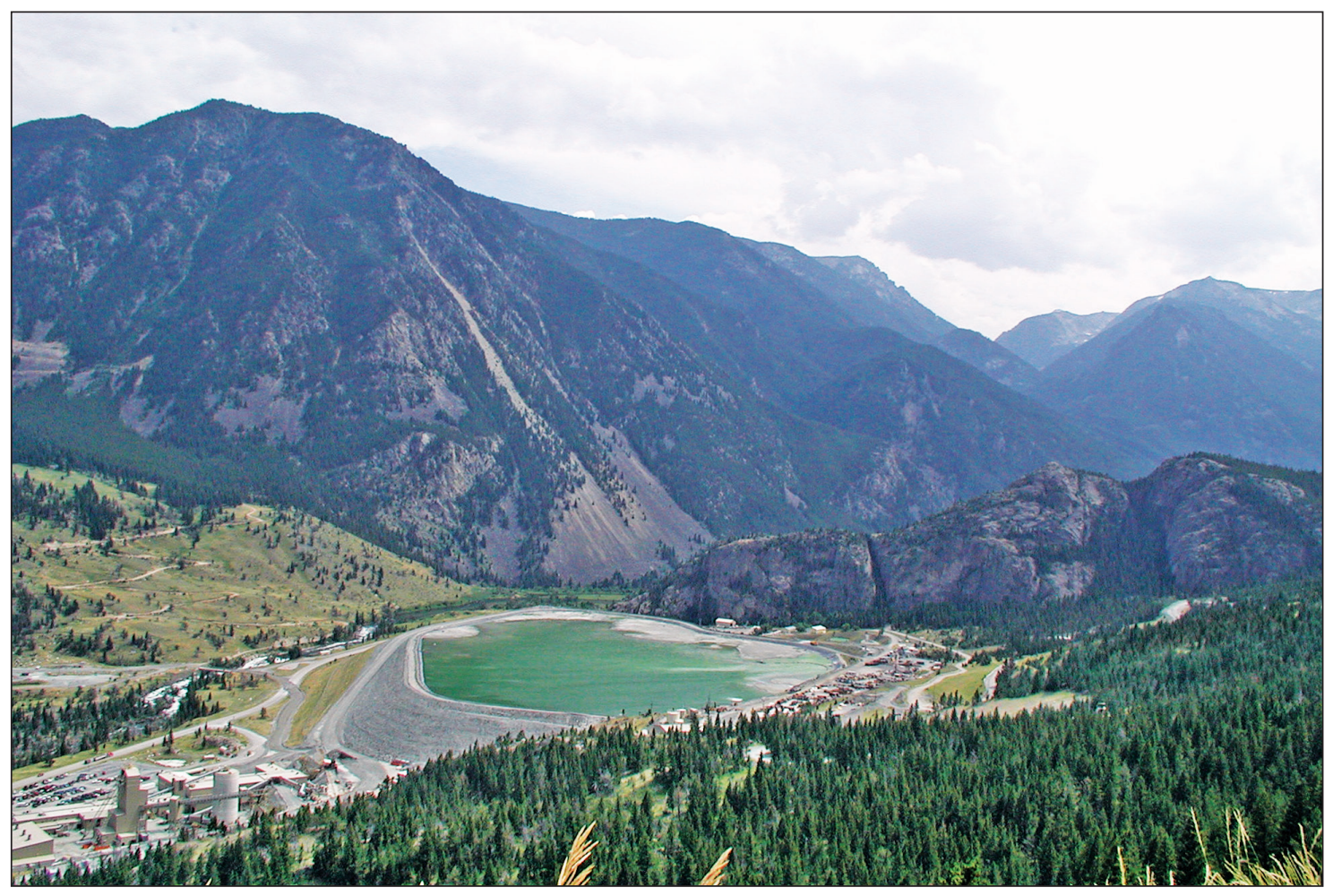

Figure N14. Photograph of the Stillwater Mine in south-central Montana, looking southeast. The pond is the tailings impoundment. The buildings in the lower left include the shaft, the mill complex, and offices. Photograph by Michael L. Zientek, 2006.

\section{Residual Deposits Formed By Weathering and Laterites}

In areas with tropical or forested warm to temperate climates, weathered red subsoil rich in secondary oxides forms on ultramafic rocks. These subsoils, or laterites, are a significant source of nickel (the other significant source of nickel is magmatic ore deposits). Laterites contain about 70 percent of the world's nickel resources, have been mined for more than 100 years, and account for about 40 percent of the world's nickel production (Gleeson and others, 2003; Dalvi and others, 2004; Mudd, 2010; Berger and others, 2011).

PGE enrichments are found in some laterites developed on ultramafic rocks, and an ongoing debate among geologists concerns whether this enrichment is related to the mobilization of the PGEs during the laterization process or to the residual accumulation of preexisting platinum-group minerals. Samples of lateritized ophiolitic mantle harzburgite from the Pirogues River area of New Caledonia contain up to 2 ppm (but average $500 \mathrm{ppb}$ ) platinum. The continuity of the PGE-enriched laterite layers relative to the discontinuous distribution of PGE-enriched chromitites in the ophiolites initially suggested that the PGEs could be concentrated through the lateritization process (Augé and Legendre, 1994); however, recent work indicates that the PGE-enriched zones are the result of the concentration of residual platinum-group mineral particles that were present in the unweathered ultramafic rock (Traoré and others, 2008). The PGE-enriched saprolitic horizon of the Falcondo nickel-laterite deposit in the Dominican Republic also appears to be a residue of primary platinum-group minerals that were dispersed in ophiolite-related ultramafic rocks (Proenza and others, 2010).

Another PGE-enriched laterite occurrence, the Syerston nickel-cobalt-platinum deposit, overlies the dunitic core of the easternmost of three plugs that make up the Tout Intrusive Complex, which is a Uralian-type intrusion in the Fifield area in New South Wales, Australia (Teluk, 2001). Preferential weathering of the ovoid dunite body formed a slab-like laterite body. The laterite extends to a depth of $40 \mathrm{~m}$ and has zones of nickel-cobalt enrichment that average $10 \mathrm{~m}$ in thickness in the middle of the weathering profile. An interval of residually concentrated platinum largely coincides with the nickel-cobalt enriched layers. Primary platinum enrichment in the host dunite may explain the distribution of platinum in the Syerston laterite profile, the exceptional grades (commonly in excess of $2.0 \mathrm{~g} / \mathrm{t}$ platinum), and the coarse grains of the platinum-group minerals. Published resources are 137 million metric tons containing $0.24 \mathrm{~g} / \mathrm{t}$ platinum; the planned nickel-cobalt open pit area (high-grade goethite zone) accounts for 91.6 million metric tons of the resource and contains 0.70 weight percent nickel and 0.12 weight percent cobalt (Teluk, 2001). 


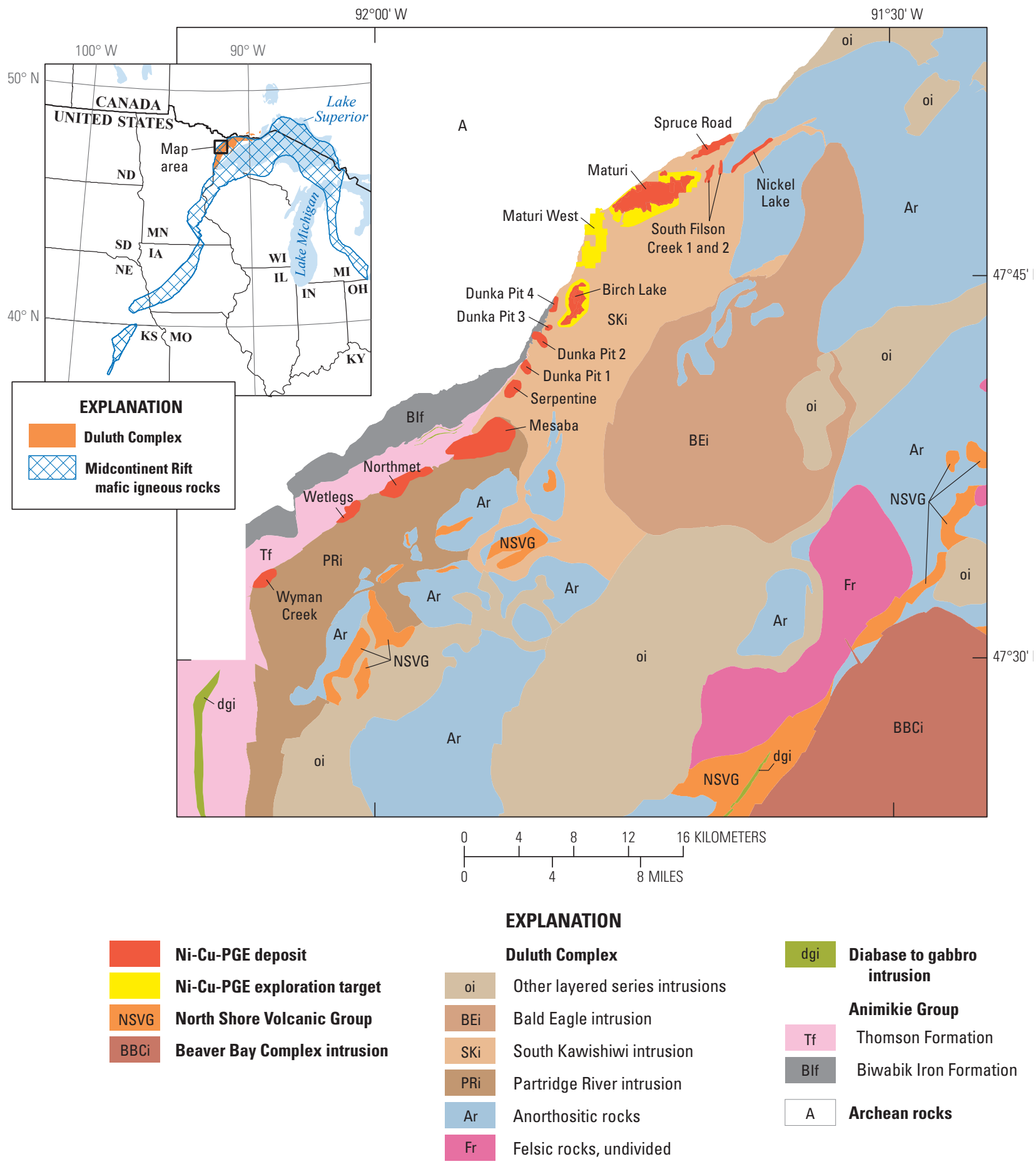

Figure N15. Map showing the geology along the western margin of the Duluth Complex, Minnesota, with the surface projection of nickel-copper-platinum-group-element (Ni-Cu-PGE) deposits and exploration targets. Exploration targets occur along the outer margins of known deposits (Birch Lake and Maturi) or as areas separated from known deposits (Maturi West). The location map shows the exposed and covered areas of the Midcontinent Rift along with the Duluth Complex. Map based on information in Miller and others (2002) and Parker and Eggleston (2012). Geology in the index map is derived from Muehlberger (1997). 


\section{Platinum Placer Deposits}

Erosion and weathering of rocks can form surficial mineral deposits. Placer deposits form when heavy particles of rocks or minerals are physically concentrated by the action of moving water. Placer deposits can form in active streams or rivers or along the shoreline of oceans or lakes. In 1824, placer platinum deposits were discovered on the Orulikha River, north of the Nizhny Tagil Massif in the central Ural Mountains (Urals) of Russia (table N3; fig. N16; Duparc and Tikonowitch, 1920; Pushkarev, 2001). From then until 1922, approximately 330 metric tons of metal was recovered from placer deposits in the Urals. At least one company is still exploring for paleoplacers that are buried beneath younger deposits of sediment and for placers that may be on river terraces along the Tylay and Kos'va Rivers in the Urals (Eurasia Mining plc, 2012). So far, the company has delineated resources in placers that contain 0.6 metric tons of platinum; average grades range from 0.303 to 0.363 gram per cubic meter (Eurasia Mining plc, 2011).

In the second half of the 20th century, platinum placer deposits were discovered at Kondyor in eastern Siberia (fig. N17; Shcheka and others, 2004) and in the Koryak area at the northern end of the Kamchatka Peninsula in eastern Russia (Tolstykh and others, 2004). The Kondyor placer deposits produced about 85 metric tons of platinum from 1984 to 2011 . After a decade of mining, approximately 45 metric tons of platinum was recovered in the Koryak area (Hurst, 2005).

The detrital platinum minerals in the placer deposits in Russia are clearly derived from small mafic to ultramafic plutons. The drainages surrounding the Nizhny Tagil Massif contained some of the most productive placer deposits in the Urals (fig. N16B). Placer mining near Nizhny Tagil began around 1839. Platinum in bedrock was first discovered in 1892 at a deposit called Krutoy Log in the Nizhny Tagil Massif (fig. N16B; Anikina and others, 2014). These plutons, which are the sources of platinum placer deposits, are circular or elliptical in plan view, pipe-like when viewed in profile (that is, in a cross-sectional view), and generally range in areal extent from about 10 to $40 \mathrm{~km}^{2}$ (Johan, 2002). The rocks that make up the plutons are a core of dunite that is concentrically surrounded by borders of clinopyroxenite, hornblendite, and gabbroic rocks. The zoned ultramafic complexes have rock textures that are consistent with (a) crystallization from magma at depth; (b) deformation, recrystallization, and annealing at high temperature; and (c) metasomatic alteration (Burg and others, 2009; Shmelev and Filippova, 2010). Rocks in these small mafic to ultramafic plutons make up a distinct rock association called Uralian-type complexes. These complexes are enigmatic because lode occurrences of platinum mineralization found in the plutons are inconsequential compared with the amount of placer platinum minerals found in the streams draining from the plutons.
Platinum mineralization in Uralian-type complexes is closely associated with chromitite pods, vein-like bodies, or schlieren within the dunite core of the plutons. In the Nizhny Tagil Massif, more than 1,600 chromitite occurrences have been mapped; most do not exceed 50 centimeters $(\mathrm{cm})$ in length and a few centimeters in thickness. Two types of chromitite are distinguished: (a) massive chromitite that grades into disseminated chromite in the dunite host, and (b) chromitite marked by serpentine rims that has a sharp boundary with the dunite host rock. The second type of chromitite is exceptionally enriched in platinum (Pushkarev and Anikina, 2002). Although the chromitites are small, the abundance of platinum can be quite high. For example, at the Krutoy Log deposit, chromite-platinum ore at the top of the orebody extended for a distance of $2 \mathrm{~m}$ in one adit. From this small volume of rock, about 30 kilograms (reported as 965 troy ounces) of native platinum metals was recovered (Mertie, 1969).

The platinum-group minerals in the placer deposits provide clues about the rocks from which they are derived. The platinum-group minerals are dominated by platinum-iron alloys but also contain some iridium and osmium alloys; few minerals with palladium or rhodium are found. The platinum nuggets in the placer deposits can be quite large (more than $10 \mathrm{~cm}$ in diameter and weighing up to several kilograms); by comparison, in most contact- and reef-type PGE ore deposits, the platinum-group minerals rarely exceed a few hundred microns in diameter $(1$ micron equals $0.0001 \mathrm{~cm})$ and weigh less than 0.0000001 kilograms. Some of the detrital platinumgroup minerals have crystal faces that reflect their internal crystalline structure (figs. N18A and N18B). Minerals that display crystal faces usually grow from a liquid or a vapor. Many nuggets contain inclusions of chromite and olivine (fig. N18C), or in some cases, form a matrix interstitial to these minerals. These textures suggest that platinum-iron alloys formed from magmas that were crystallizing chromite and olivine. Collectively, these observations indicate that the platinum nuggets are not derived from concentrations of magmatic sulfide minerals; rather, it appears that the nuggets were crystallized directly from silicate melt or a magmatic vapor.

Platinum placers are derived from similar ultramafic plutons in Alaska; British Columbia, Canada; Colombia; Ethiopia; and New South Wales, Australia (table N3). The largest alluvial PGE resource in the United States occurs south of Goodnews Bay in Alaska (fig. N19). The Goodnews Bay placer deposits were discovered in 1926 and mined between 1927 and 1975. Approximately 18 metric tons of platinum was recovered from the Salmon River and its tributaries (Johnston, 1962; Mertie, 1976; Barker, 1986; Tolstykh and others, 2002). Significant placer resources may remain in the unmined, deeply buried ground of the lower Salmon River Valley as well as in waste material (tailings) from previous dredging operations (Southworth and Foley, 1986). 
Table N3. Areas with significant placer platinum production, and estimates of cumulative production and grades.

[g/m³, gram per cubic meter; km, kilometer; n.d., no data; PGE, platinum-group element]

\begin{tabular}{|c|c|c|c|c|}
\hline Location & $\begin{array}{l}\text { Cumulative } \\
\text { production } \\
\text { (metric tons) }\end{array}$ & Dates & Grade(s) & Reference(s) \\
\hline $\begin{array}{l}\text { Ural Mountains, } \\
\text { Russia }\end{array}$ & 330 to 435 & $\begin{array}{l}1824 \text { to } \\
\text { present }\end{array}$ & $\begin{array}{l}\text { Initial tenors of placers in the Martian, Syssim, } \\
\text { Tschauch, and Wyssim Rivers, which drain } \\
\text { the Nizhniy Tagil area, were about } 400 \mathrm{~g} / \mathrm{m}^{3} \text {; } \\
\text { by World War I, the grades of placers in these } \\
\text { rivers were } 0.41 \text { to } 35 \mathrm{~g} / \mathrm{m}^{3} \text {. } \\
\text { The average grade of the placers in the Nizhniy Tagil } \\
\text { district early in its history is estimated to be about } \\
20 \mathrm{~g} / \mathrm{m}^{3} \text {. } \\
\text { Grades currently estimated for the West Kitlim placer } \\
\text { deposit are } 0.303 \text { to } 0.363 \mathrm{~g} / \mathrm{m}^{3} \text {. }\end{array}$ & $\begin{array}{l}\text { Lumb (1920); Eurasia } \\
\text { Mining plc (2011); } \\
\text { Malitch and Thalham- } \\
\text { mer (2002); Pushkarev } \\
\text { and Anikina (2002); } \\
\text { Pushkarev (2001); } \\
\text { Teluk (2001) }\end{array}$ \\
\hline Kondyor, Russia & 85 & 1984 to 2011 & $\begin{array}{l}\text { Average grade of the placer deposit is } 1.6 \mathrm{~g} / \mathrm{m}^{3} \text { PGEs. } \\
\text { Drainages within the intrusive body have grades of } \\
4 \mathrm{~g} / \mathrm{m}^{3} \text {. The grades } 50 \mathrm{~km} \text { downstream are about } \\
0.5 \mathrm{~g} / \mathrm{m}^{3} \text {. }\end{array}$ & $\begin{array}{l}\text { Russian Platinum } \\
\text { (2011a); Shcheka } \\
\text { and others (2004) }\end{array}$ \\
\hline Kamchatka, Russia & 45 & $\begin{array}{l}\text { Approximately } \\
10 \text { years of } \\
\text { mining beginning } \\
\text { after } 1991\end{array}$ & The average mined grade is $0.28 \mathrm{~g} / \mathrm{m}^{3}$ platinum. & Hurst (2005) \\
\hline $\begin{array}{l}\text { Goodnews Bay, } \\
\text { Alaska }\end{array}$ & 19 to 22 & 1927 to 1975 & $\begin{array}{l}\text { At Squirrel Creek, high-grade placers contained } \\
4.1 \mathrm{~g} / \mathrm{m}^{3} \text {, with an average tenor of } 1.2 \mathrm{~g} / \mathrm{m}^{3} \text {. } \\
\text { At Clara Creek, early small-scale mining of placers } \\
\text { with a grade of } 3.25 \mathrm{~g} / \mathrm{m}^{3} \text {, with an average tenor } \\
\text { of } 0.81 \mathrm{~g} / \mathrm{m}^{3} \text {. } \\
\text { A cleanup a short distance from the mouth of } \\
\text { Fox Gulch indicated grades of } 0.81 \text { to } 1.2 \mathrm{~g} / \mathrm{m}^{3} \text {. } \\
\text { Average grade of } 470 \text { samples is } 0.192 \mathrm{~g} / \mathrm{m}^{3} \text {, with } \\
\text { a maximum value of } 1.6 \mathrm{~g} / \mathrm{m}^{3} \text {. }\end{array}$ & $\begin{array}{c}\text { Johnston (1962); Mertie } \\
\text { (1976); Barker (1986); } \\
\text { Southworth and Foley } \\
\text { (1986); Pacific North } \\
\text { West Capital Corp. } \\
\text { (2006); Chatterjee and } \\
\text { Bandopadhyay (2011) }\end{array}$ \\
\hline Yubdo, Ethiopia & 2.0 & 1926 to 1956 & $\begin{array}{l}\text { Eluvium-Grades were initially } 0.3 \text { to } 0.5 \mathrm{~g} / \mathrm{m}^{3} \text { but } \\
\text { decreased to } 0.11 \mathrm{~g} / \mathrm{m}^{3} \text { as mining moved away } \\
\text { from the core of the intrusion. } \\
\text { Alluvium - Grades were } 0.25 \text { to } 0.83 \mathrm{~g} / \mathrm{m}^{3} \text { in test pits. }\end{array}$ & Molly (1959) \\
\hline $\begin{array}{l}\text { Tulameen district, } \\
\text { British Columbia, } \\
\text { Canada }\end{array}$ & 0.6 & 1885 to 1932 & n.d. & Mertie (1969) \\
\hline $\begin{array}{l}\text { Fifield district, New } \\
\text { South Wales, } \\
\text { Australia }\end{array}$ & 0.6 & $\begin{array}{l}1893 \text { to mid- } \\
1960 \text { s; most } \\
\text { production from } \\
\text { first few years } \\
\text { of operation }\end{array}$ & n.d. & $\begin{array}{l}\text { Mertie (1969); Platina } \\
\quad \text { Resources Ltd. (2006) }\end{array}$ \\
\hline
\end{tabular}



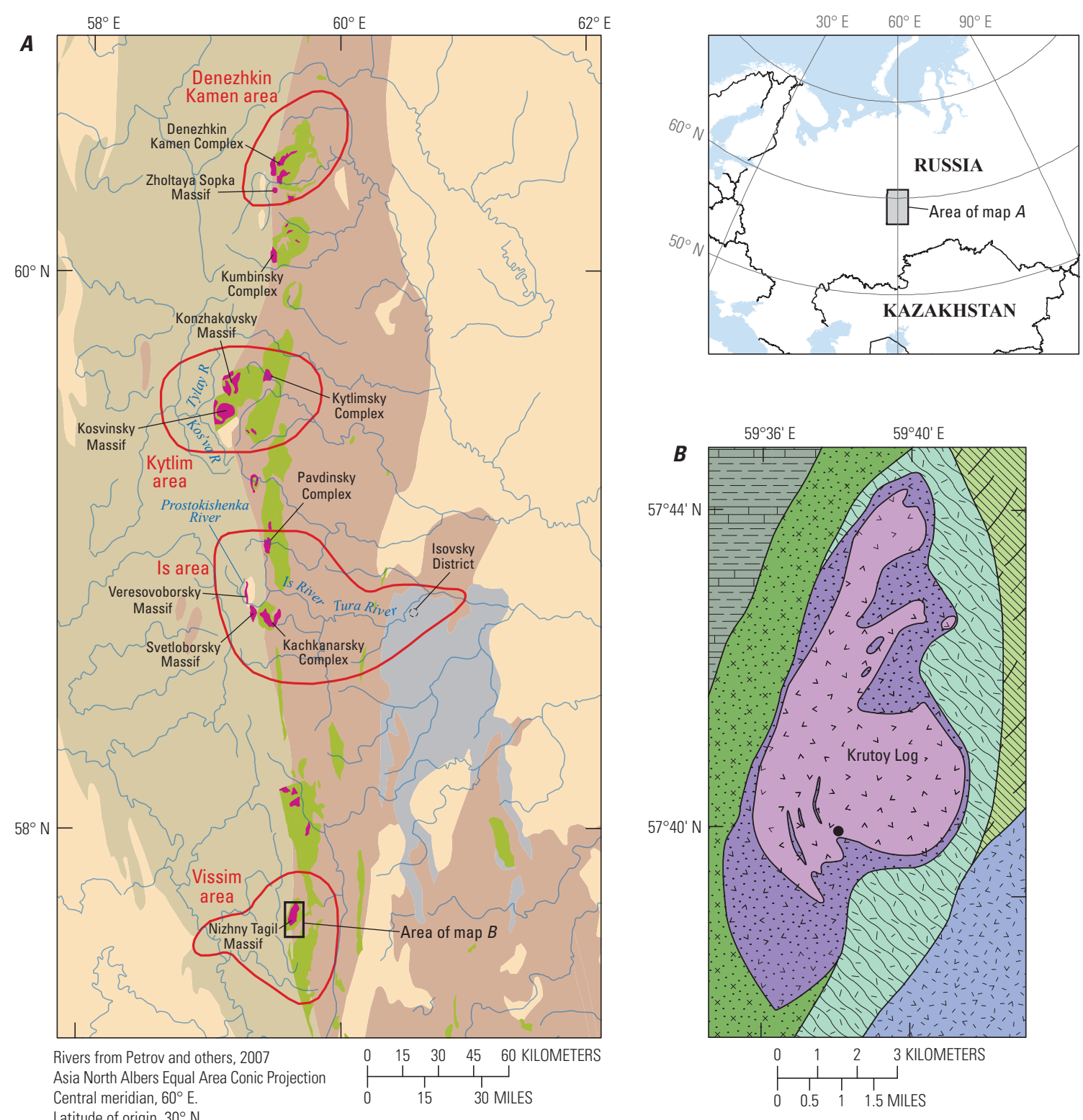

Map $A$

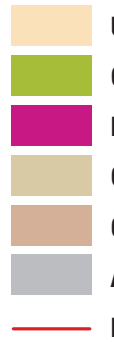

Gabbro

Pyroxenite and dunite

Orogenic belts
Undeformed cover of sedimentary rocks

Orogenic belts and passive continental margin

Archean and Proterozoic basement rocks

Platinum-producing area
EXPLANATION

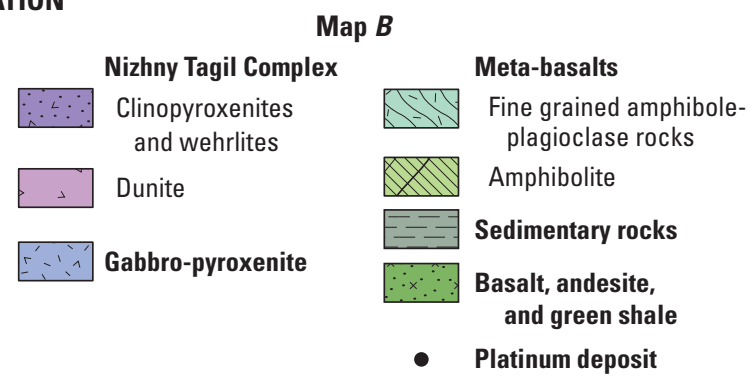

Figure N16. Maps illustrating the distribution of platinum deposits in the Ural Mountains, Russia. A, Generalized geology, location of platinum placer districts, and platinum-producing areas in the Ural Mountains, Russia. Placer platinum deposits are derived from pyroxenitic and dunitic intrusions; the platinum-iron alloy derived from the Veresovoborsky Massif and the Svetloborsky Massif occurs in placer deposits that extend about 100 kilometers downstream along the Is and Tura Rivers. Modified from Zonenshain and others (1988), Anderson and Martineau (2002), and Petrov and others (2007). B, Geology of the Uralian-type Nizhny Tagil Massif and the location of the Krutoy Log, where the first bedrock source of the platinum deposit was discovered. Platinum minerals were concentrated in chromitites that occur in the dunitic core of the lithologically zoned pluton. Modified from Levin and others (2010). 


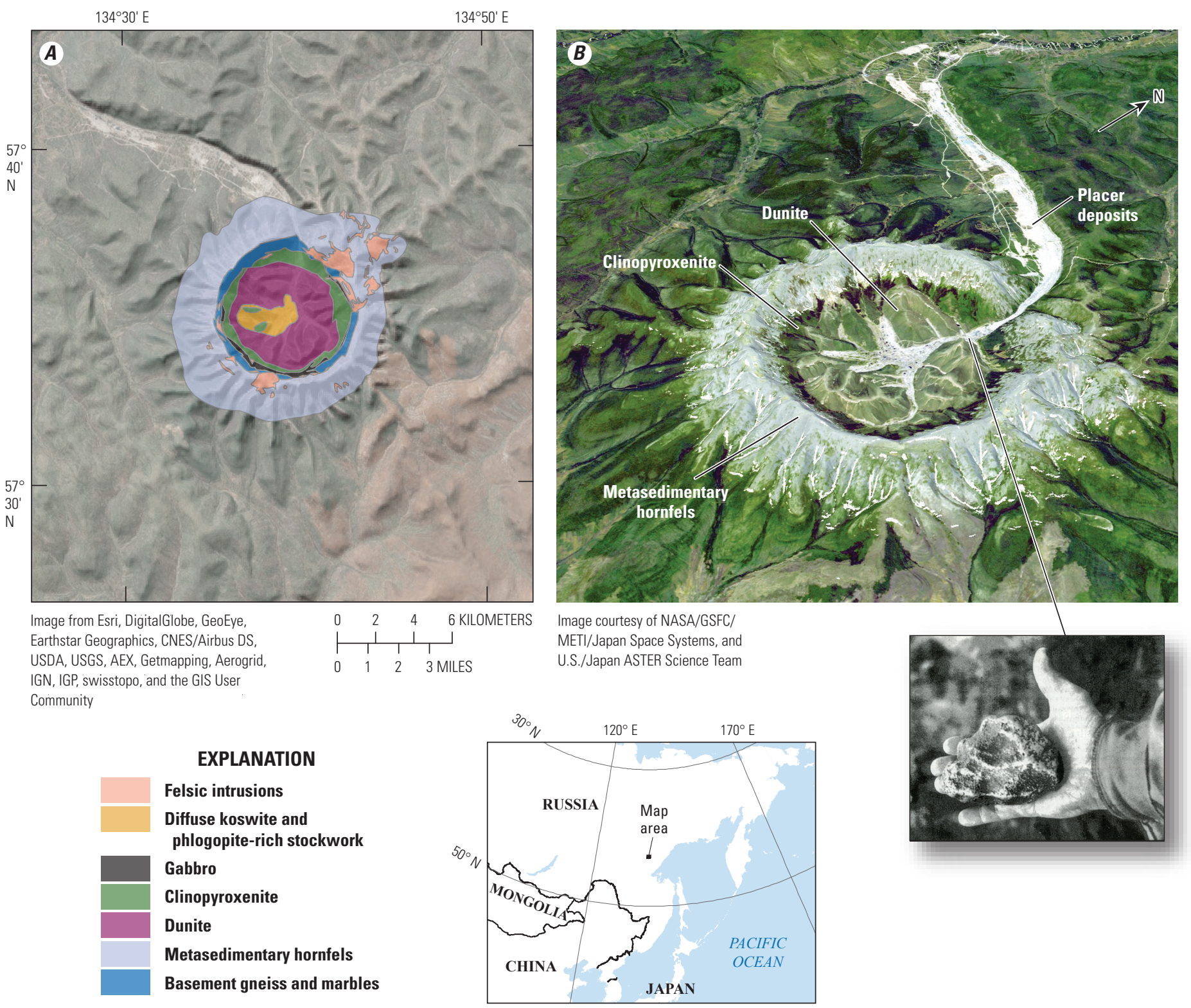

Figure N17. Geology and imagery of the Uralian-type Kondyor Massif, which is located in eastern Siberia, Russia, north of the city of Khabarovsk. A, Geologic map of the massif, showing that the circular pluton consists of a central core of dunite, which is surrounded by clinopyroxenite and gabbro. Emplacement of the pluton metamorphosed the surrounding sedimentary rocks, forming hornfels. Geology simplified from Burg and others (2009). B, Oblique view of the Kondyor Massif showing the core of dunite surrounded by clinopyroxenites. This circular intrusion is about 10 kilometers in diameter; the prominent topographic ridge, which is up to 600 meters high, is underlain by contact metamorphosed rocks that surround the intrusion. The intrusion is the source of coarse crystals of platinum-iron alloy coated with gold that are recovered in streams that drain from the complex. An example of a coarse platinum nugget recovered from the Kondyor Massif is shown in the black-and-white picture. This view was created by draping a simulated natural color Advanced Spaceborne Thermal Emission and Reflection Radiometer ASTER composite image over an ASTER-derived digital elevation model; the image was acquired on June 10, 2006. Photograph courtesy of NASA/GSFC/METI/Japan Space Systems, and U.S./Japan ASTER Science Team. The image of the platinum nugget is from Malitch (1999). 

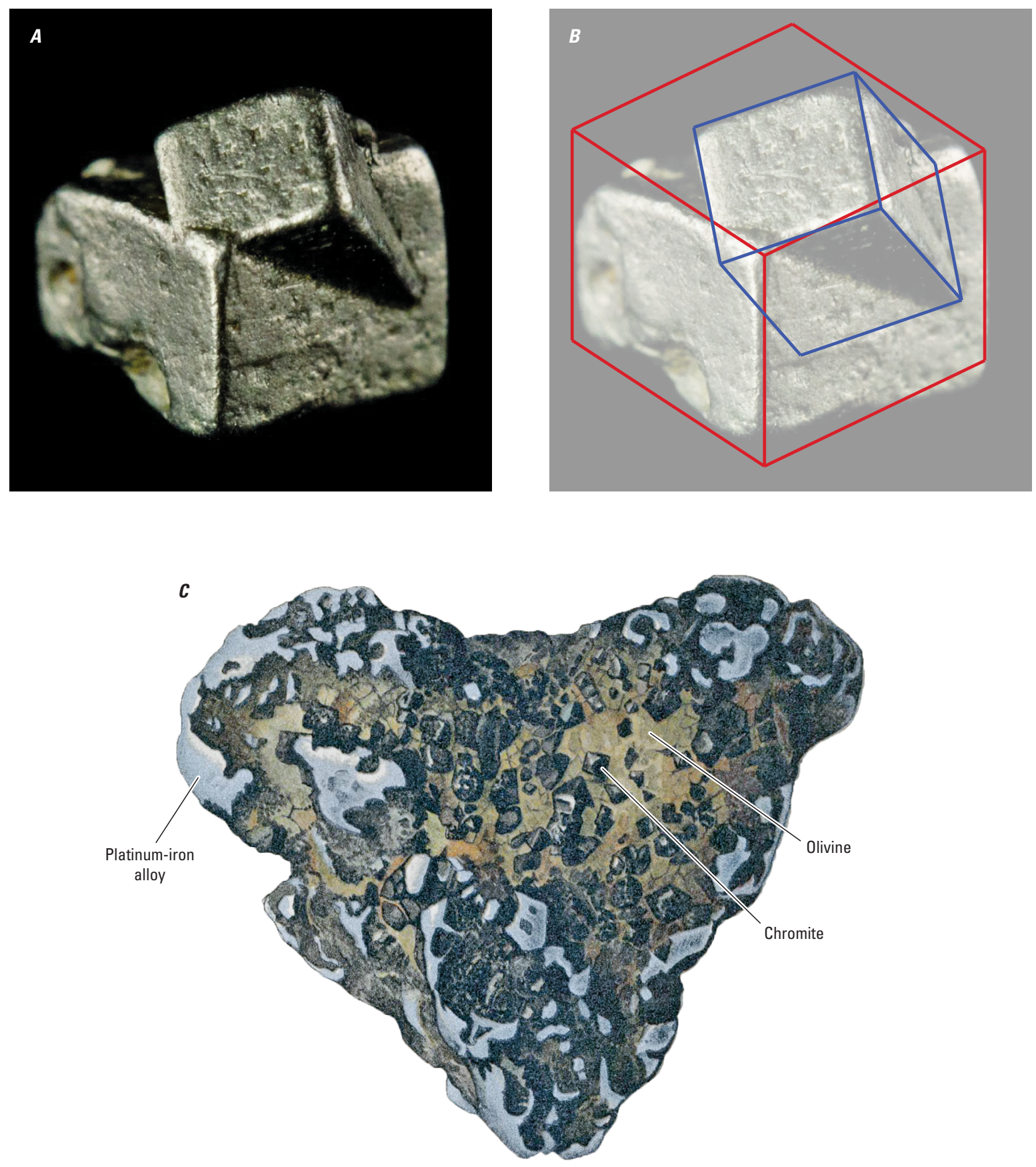

Figure N18. Photograph and lithograph showing the morphology of platinum-iron-alloy nuggets derived from Uralian-type intrusions. $A$, Photograph of silvery-gray nugget of isoferroplatinum from the Kondyor Massif, Russia. The nugget, which is about 4 millimeters $(\mathrm{mm})$ long, consists of two intergrown crystals of isoferroplatinum; each crystal forms a cube with smooth crystal faces and sharp edges and corners (Photograph courtesy of TreasureMountainMining.com). $B$, Sketch of the isoferroplatinum nugget illustrating the cube-shaped crystals. $C$, Lithograph of a platinum nugget with olivine and octahedral chromite, from the Tulameen district, British Columbia, Canada. The longest dimension on the nugget is about $10 \mathrm{~mm}$. In this nugget, platinum-iron alloy occurs interstitial to (in between) magmatic crystals of olivine and chromite. The texture implies that the platinum-iron alloy grew slightly later than the earlier formed olivine and chromite. Image is from Kemp (1902). 

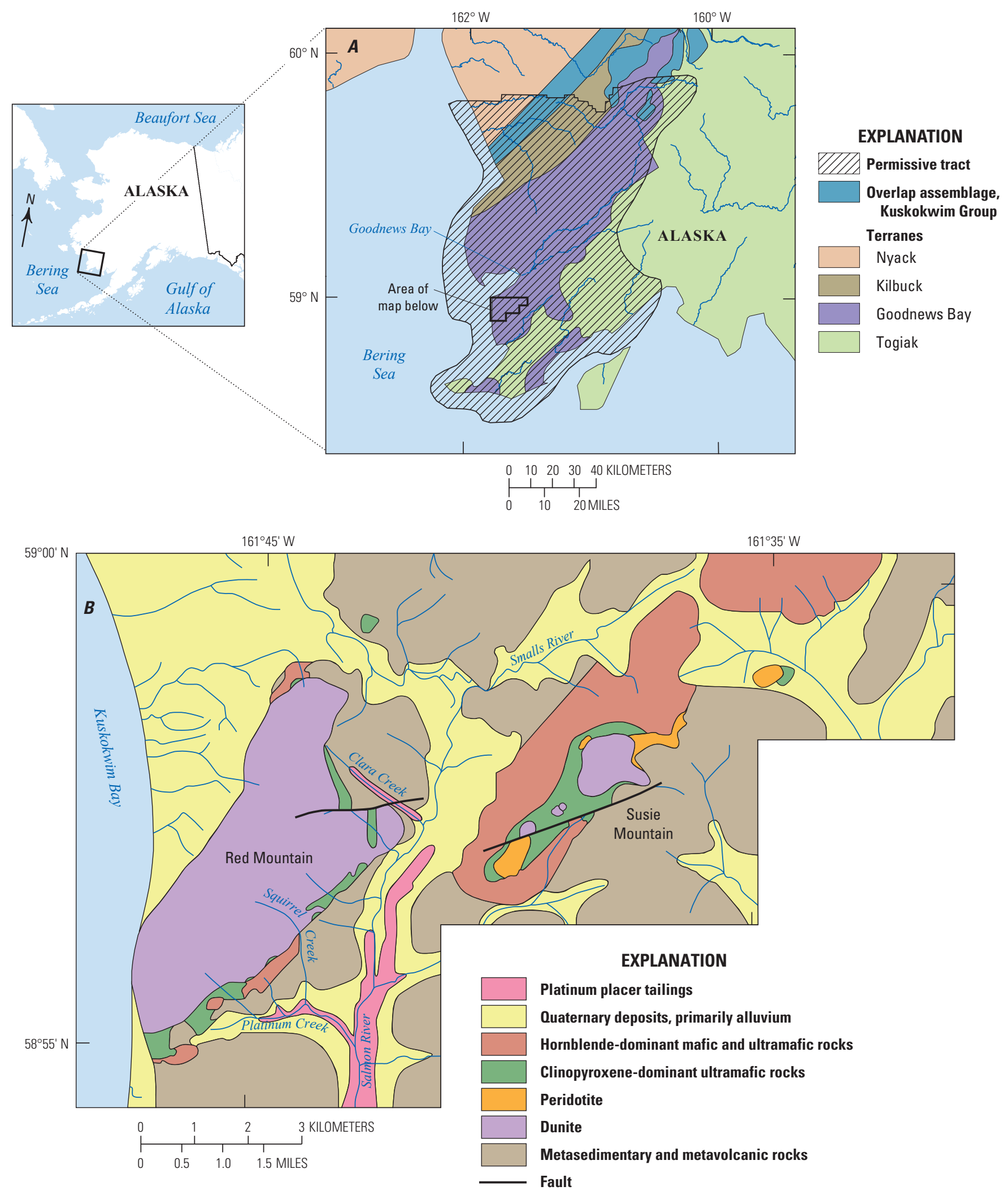

Figure N19. Maps illustrating platinum-group-element (PGE) resources in southeastern Alaska. $A$, Location of the permissive tract assessed for undiscovered placer platinum resources and the major geologic provinces (terranes) it encompasses. The permissive tract is the area where undiscovered PGE resources could be present (Schmidt and others, 2007). $B$, Geologic map of the Goodnews Bay area showing where platinum placer deposits have been mined (platinum placer tailings). The placer platinum deposits can be followed upstream to the Red Mountain pluton, a Uralian-type intrusion that could be the bedrock source of the platinum minerals found in the placers. Modified from Tolstykh and others (2002). 


\section{Resources and Production}

Discovered mineral resources include the total amount of identified mineral resources that are in the ground as well as the cumulative past production (U.S. Geological Survey National Mineral Resource Assessment Team, 2000). This section begins with an overview of historic and current primary and secondary production of PGEs. Primary production is when metal that occurs in rocks is mined and transferred to above-ground material stock; secondary production is from recycled material or scrap. The section also includes a discussion of the identified mineral resources of PGEs. Identified mineral resources refer to the mineralized material in the ground whose location, grade, quality, and quantity are known or can be estimated from specific geologic evidence (U.S. Bureau of Mines and U.S. Geological Survey, 1980). Identified mineral resources represent the current stock of material in the ground (mineral inventory) that might be mined. The amounts of identified resources discussed this chapter were current as of 2012.

\section{Production}

Up to 1920, almost all of the world's PGE production came from placer deposits in Russia and Colombia. The discovery of nickel deposits in solid rock in the Sudbury area of Ontario, Canada, in the 1800s (Giblin, 1984) roughly coincided with technological innovations that used nickel to strengthen traditional steels. This technological innovation led to extensive development of the Sudbury deposits; in the first half of the 20th century, Sudbury produced approximately 80 percent of the world's nickel (Prevec, 1997). PGEs were recovered as a byproduct of nickel mining in Sudbury; by 1934, Canada had become became the world's leading producer of PGEs.

Most of the PGEs produced today are from mineral deposits that were discovered in the Noril'sk-Talnakh area of Russia in 1919 (Kunilov, 1994; Likhachev, 1994) and in South Africa in the 1920s (Wagner, 1929). Significant development of these deposits did not begin until the 1960s when industrial demands for PGEs increased. About the same time that new and extraordinarily PGE-enriched deposits were discovered in the Noril'sk-Talnakh area in Russia (Kunilov, 1994), Anglo American Platinum Ltd. gained a controlling stake in the PGE industry in South Africa (Mattera, 2008) and South Africa had an economic boom (Rouillard, 1997).
As a result, beginning in the 1960s, PGE production increased in South Africa and the Soviet Union (Russia), such that South Africa became, and still is, the leading producer of platinum and rhodium, and Russia was and is the world's leading producer of palladium (fig. N20).

Approximately 14,200 metric tons of PGEs was produced from 1900 to 2011, and roughly 95 percent of that amount (about 13,500 metric tons) was produced from 1960 onward. The breakdown of production by country shows that about 90 percent of production since 1900 has come from South Africa and Russia; Canada, the United States, and Zimbabwe accounted for 5 percent, 2 percent, and 1 percent of production, respectively (fig. N21).

A secondary supply of platinum, palladium, and rhodium is obtained through the recycling of catalytic converters from end-of-life vehicles, jewelry, and electronic equipment. Recycling volumes are sensitive to PGE prices; higher prices typically lead to higher recycling volumes owing to the greater incentive to recycle. Recycled platinum, palladium, and rhodium provide a significant proportion of the total supply and are sufficient to close the gap between mine production and consumption. For example, in 2011, about 24 percent

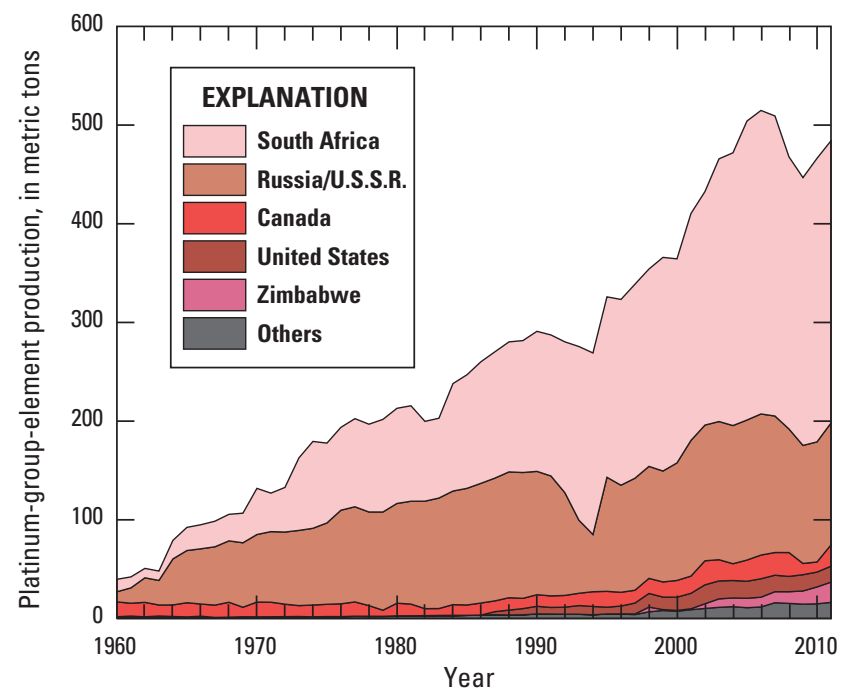

Figure N20. Graph showing world platinum-groupelement production, by country and year, from 1960 to 2011. The layers of the graph are placed one above the other, forming a cumulative total. Data are from U.S. Bureau of Mines (1933-34, 1933-96) and U.S. Geological Survey (1997-2016). 


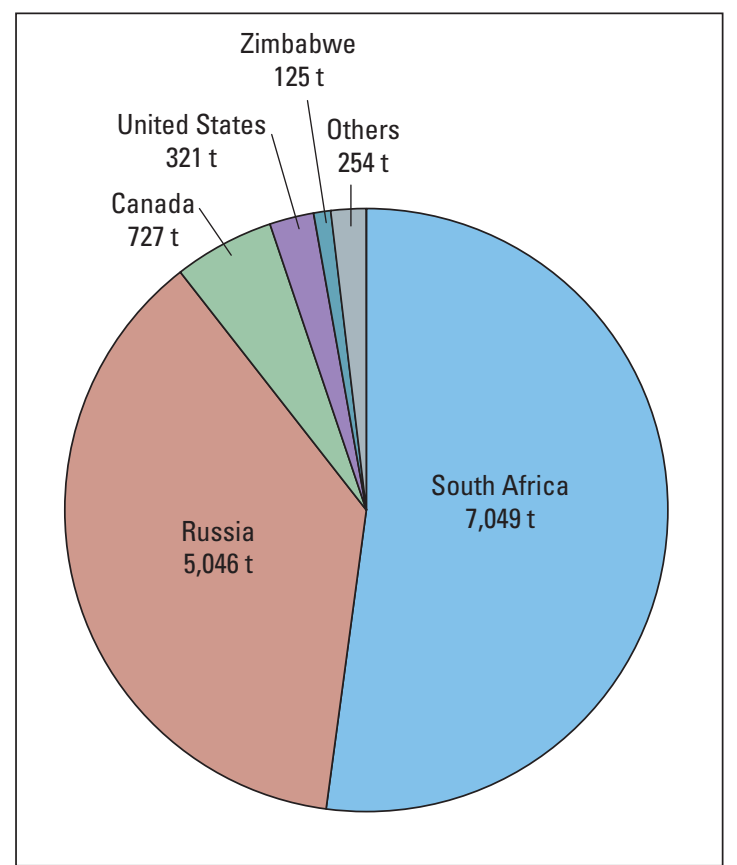

Figure N21. Pie chart showing world platinumgroup-element (PGE) production from 1960 to 2011, by country and amount (in metric tons [t]) . Data are from U.S. Bureau of Mines (1933-34,1933-96) and U.S. Geological Survey (1997-2016). of the total supply of platinum and palladium and about 27 percent of the total supply of rhodium were obtained through recycling (Butler, 2012).

\section{Identified Resources}

Exploration and mining companies have delineated approximately 100,000 metric tons of PGE (and minor amounts of gold) resources in mineral deposits around the world that remain to be developed (table N4). This estimate was derived by compiling mineral inventory information about in situ estimates of the tonnage and grade of mineralized rock with "realistic prospects of eventual economic extraction" (Weatherstone, 2008) published by exploration and mining companies and geological surveys. To be considered an identified resource for this compilation, the evaluation of tonnage and grade of mineralized rock must be based on (a) direct sampling of the ore, and (b) industry standard resource estimation practices. The estimate of 100,000 metric tons is comparable to the 91,000 metric tons recently reported by Mudd (2012) (table N4). Most of the difference is accounted for by the larger estimate for the Platreef deposit of the Bushveld Complex in this chapter. For context, the total net consumption of PGEs in 2012 was approximately 460 metric tons (Platinum Today, 2013c).

Table N4. Identified platinum-group-element and gold resources, summarized by deposit type and location.

[Data are from table N10 at the end of this chapter. Numbers may not add to totals because of rounding]

\begin{tabular}{llcr}
\hline $\begin{array}{c}\text { Deposit } \\
\text { type }\end{array}$ & \multicolumn{1}{c}{ Deposit } & $\begin{array}{c}\text { PGE and gold resources } \\
\text { compiled for this chapter } \\
\text { (metric tons) }\end{array}$ & $\begin{array}{r}\text { PGE and gold resources } \\
\text { compiled by Mudd, 2012 } \\
\text { (metric tons) }\end{array}$ \\
\hline Reef & $\begin{array}{l}\text { Merensky Reef and UG2 Chromitite, Bushveld } \\
\text { Complex, South Africa }\end{array}$ & 58,000 & 56,000 \\
& Main Sulphide Zone, Great Dyke, Zimbabwe & 8,200 & 8,700 \\
& J-M Reef, Stillwater Complex, Montana & 2,200 & 620 \\
& Other areas & 2,700 & 1,700 \\
& $\quad$ Total, reef-type deposits & $\mathbf{7 1 , 0 0 0}$ & $\mathbf{6 7 , 0 0 0}$ \\
Contact & Platreef, Bushveld Complex, South Africa & 17,000 & 1,600 \\
& Other areas & 3,100 & $\mathbf{9 , 3 0 0}$ \\
& $\quad$ Total, contact-type deposits & $\mathbf{2 0 , 0 0 0}$ & 11,000 \\
Conduit & Noril'sk-Talnakh area, Russia & 10,000 & 2,100 \\
& Other areas & 1,200 & $\mathbf{1 3 , 0 0 0}$ \\
\hline
\end{tabular}




\section{Tonnage and Grade Relations for Magmatic Ore Deposits}

Tonnage and total PGE and gold grade relations for identified resources in magmatic deposits are shown in figure N22. Estimates of total PGE and gold grade can vary over about three orders of magnitude, whereas tonnage can vary over five orders of magnitude. Tonnage and grade are not strongly correlated, which is typical for mineral deposits of a given type. Some conduit-type deposits have lower PGE and gold grades than reef-type deposits because conduit-type deposits are polymetallic deposits in which copper, nickel, PGEs, and gold all contribute to the value of the ore. In reef-type deposits, the value of the ore is primarily in the PGE and gold concentrations. In terms of contained metal, most deposits contain more than 1 metric ton of PGEs and gold. For any values less than 1 metric ton, it simply is not economic to determine the tonnage and grade. In 2012, world mine production was about 450 metric tons of PGEs and world usage was about 615 metric tons (Loferski, 2013b). The shaded area in figure N22 highlights those deposits that have more than 1 year's worth of contained PGEs, given current rates of production and usage. Only a fraction of the deposits in the world have enough contained metal to satisfy multiple years of world demand.
Mineral deposits occur rarely in Earth's crust, and large ones are especially uncommon (Singer, 1995). Most of the known metal for many mineral commodities is contained in a few, very large deposits (Singer and DeYoung, 1980). For most types of mineral deposits, the grade of the ore varies by about one order of magnitude and the tonnage varies by several orders of magnitude among deposits. As a result, contained metal correlates strongly with tonnage. For porphyry copper deposits (which are the world's leading source of copper), for example, 10 percent of the deposits accounts for approximately 60 percent of the identified copper resource whereas the bottom 50 percent of the deposits accounts for less than 5 percent of the identified copper resources (fig. N23A). For the PGEs, this correlation is more pronounced. Ten percent of PGE deposits account for more than 80 percent of identified PGE resources whereas the bottom 50 percent of the PGE deposits accounts for less than 1 percent of identified PGE resources. Thirty percent of PGE deposits contain more than 97 percent of the world's identified PGE resources, and almost all these deposits are associated with three areasthe Bushveld Complex in South Africa, the Great Dyke in Zimbabwe, and the Noril'sk-Talnakh area in Russia (fig. N23B).

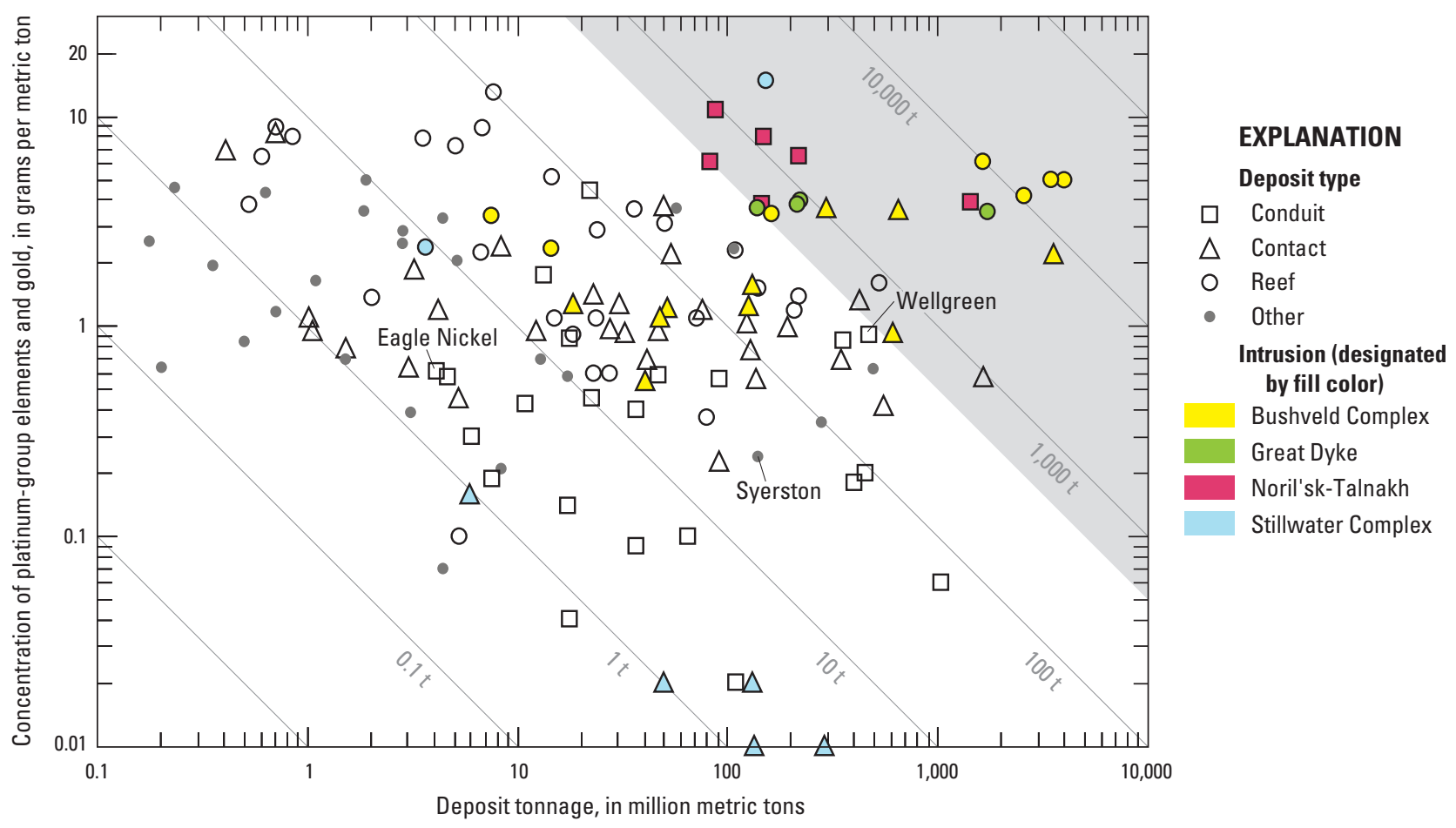

Figure N22. Plot showing the relation between tonnage and grade of remaining resources for conduit-type, reef-type, and other types of deposits enriched in platinum-group elements (PGEs). Diagonal lines are isolines that show amounts of contained PGEs and gold in the deposits, in metric tons (t). Annual world production and usage of PGEs, as of 2012, was about 450 metric tons. The shaded area on the figure highlights those deposits that are large enough to contain more than 1 year's worth of the world's PGE needs. 


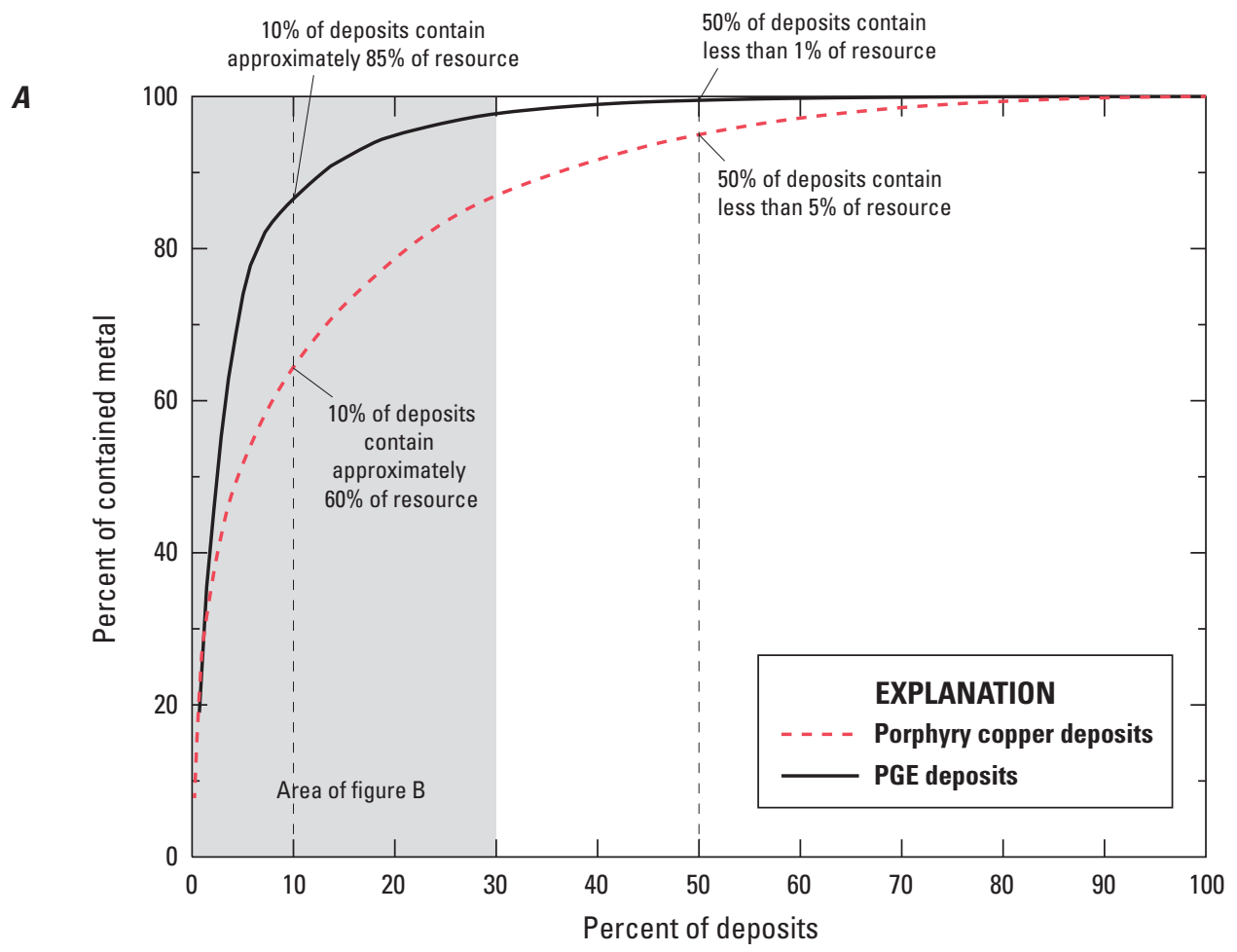

B

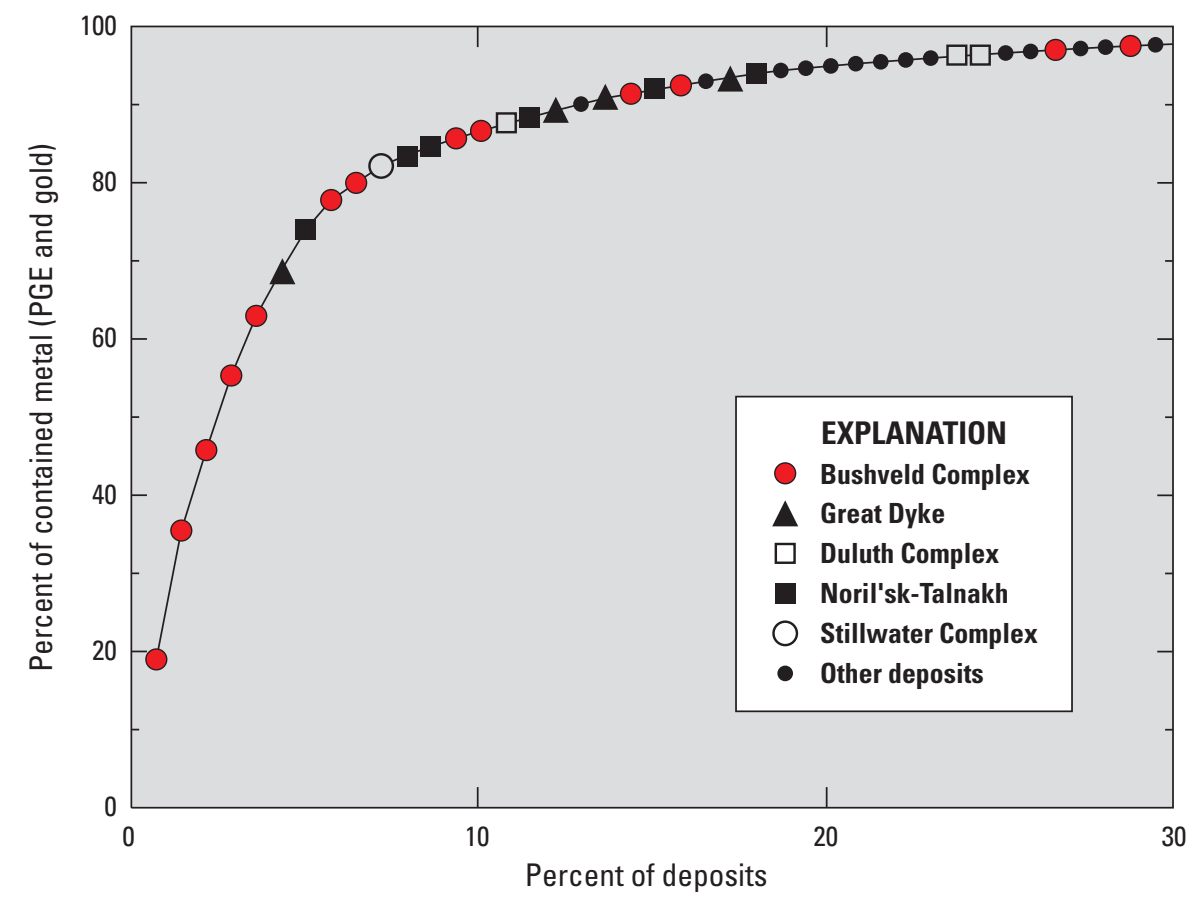

Figure N23. Graphs showing the percent of contained metal against percent of deposits for $A$, the world's platinum-group-element (PGE) and porphyry copper deposits, and $B$, the top 30 percent of the world's PGE deposits. In $A$, the curves are derived from compilations of known deposits and show that most of the contained metal in a given deposit type is associated with a small percentage of very large deposits. Both deposit types show the effect, but it is more pronounced for PGE deposits. In $B$, the curve focuses on the largest deposits, showing the data points and the name of the igneous intrusion hosting the deposit. Most of the large deposits are associated with the Bushveld Complex in South Africa, the Great Dyke in Zimbabwe, and sills in the Noril'sk-Talnakh area of Russia. Data for porphyry copper are from Singer and others (2008). PGE data are from table N10 at the end of this chapter. 
Seventy-two percent of the world's PGE resources are found in reef-type and contact-type deposits in the Bushveld Complex, South Africa (table N4). The conduit-type magmatic deposits in the Noril'sk-Talnakh area, Russia, account for 10 percent of the world's identified PGE resources. Eight percent of the world's identified PGE resources are in the Great Dyke, Zimbabwe. In fact, more than 97 percent of all the world's identified PGE resources are contained in only 14 intrusions or intrusive complexes (table N5 at back of chapter).

When considered by deposit type alone, 69 percent of identified PGE resources are associated with reef-type deposits, 20 percent are associated with contact-type deposits, and 11 percent are associated with conduit-type deposits (table N4). For reef-type deposits, 81 percent of identified resources have been delineated in the Bushveld Complex (South Africa); 12 percent in the Great Dyke (Zimbabwe); and 3 percent in the Stillwater Complex (Alaska). For contact-type deposits, 85 percent of the world's identified resources are found in the Bushveld Complex. For conduittype deposits, about 90 percent of the identified resources are found in the Noril'sk-Talnakh area of Russia.

For simplicity, the previous discussion has focused on total PGE production and resources; however, individual PGEs do have different values and uses. For example, platinum and rhodium are more valuable economically than palladium, and the iridium market is much smaller than the markets for platinum and palladium. The proportions of the PGEs differ among deposits, however (fig. N24). The deposits in South Africa and Zimbabwe have a higher proportion of platinum than any other major deposit in the world. The proportion of palladium is much higher in the deposits in the Noril'sk-Talnakh area in Russia.

\section{Undiscovered (Hypothetical and Speculative) Resources (United States and Global)}

In addition to the resources of PGEs that have been discovered (identified), additional PGEs may be present as undiscovered resources in areas adjacent to identified magmatic deposits and in deposits that remain to be discovered.

\section{Extensions to Identified Deposits}

Additional PGE resources may be present in areas adjacent to or near deposits that now dominate world supply. Although resources for reef-type and contact-type PGE deposits are formally delineated in advance of mining, the extent of the deposits is never completely delineated because the upfront costs would be too great. Instead, mining companies conduct enough research and work to ensure that the deposit contains adequate resources to justify mine development. It is possible, therefore, that some deposits are larger than previously thought.

In the Bushveld Complex, South Africa, relatively unexplored extensions of the Merensky Reef and the UG2 Chromitite deposits could contain an additional 33,000 metric tons of platinum and 32,000 metric tons of palladium to a depth of $3 \mathrm{~km}$ (Zientek and others, 2014). These reef-type PGE deposits are in the form of vast sheetlike orebodies. Mining has started at the surface and has progressed to depths of $2 \mathrm{~km}$ in some regions (fig. N25). Likewise, the Platreef in the Bushveld Complex could contain an estimated 1,100 metric tons of platinum and nearly 1,400 metric tons of palladium (based on a mean estimate to a depth of $1 \mathrm{~km}$ ). The Great Dyke of Zimbabwe
Figure N24. Graph showing contained platinum-group element (PGE) and gold metal against the ratio of palladium to platinum for the major PGE deposits of the world. The only identified deposits in which platinum is the dominant metal are associated with the Bushveld Complex in South Africa and the Great Dyke in Zimbabwe. PGE data are from table N10 at the end of this chapter. MR, Merensky Reef; Pd, palladium; Pt, platinum, UG2, UG2 Chromitite

\begin{tabular}{l}
\multicolumn{2}{c}{ EXPLANATION } \\
Intrusion or area \\
- Bushveld Complex $\quad$ Noril'sk Talnakh \\
$\square$ Duluth Complex $\quad$ O Stillwater Complex \\
$\Delta$ Great Dyke
\end{tabular}

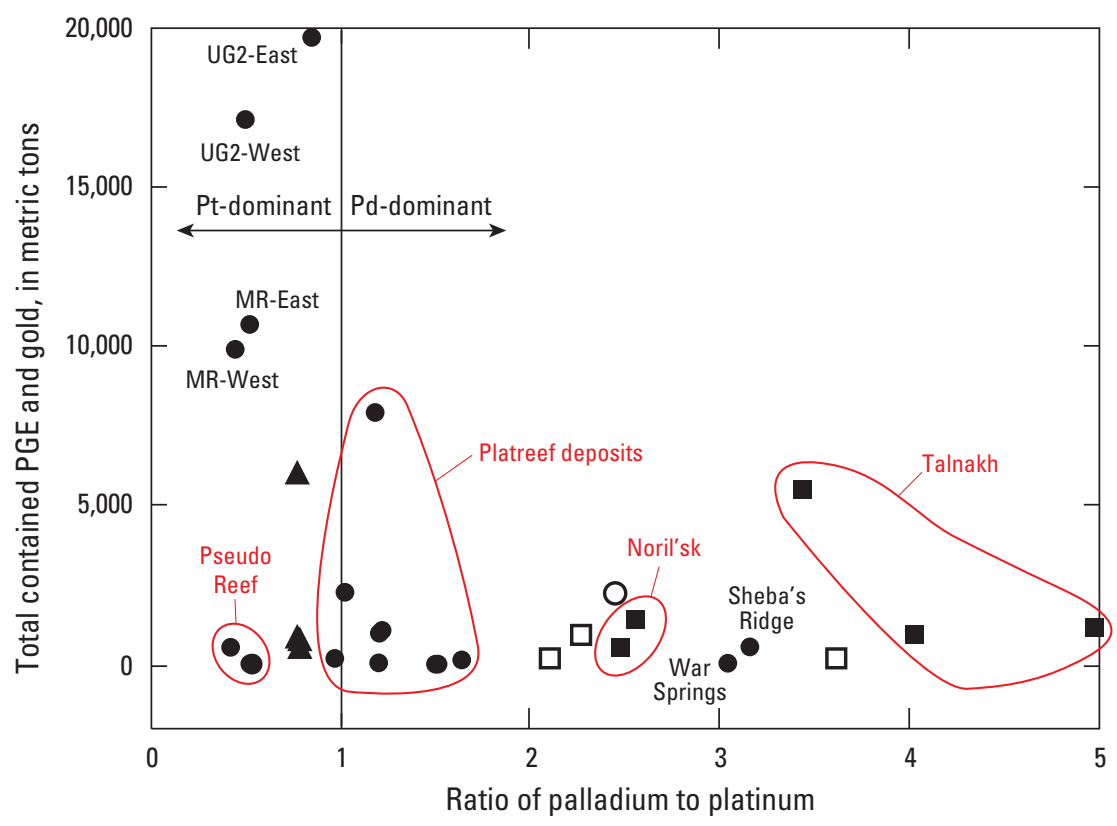




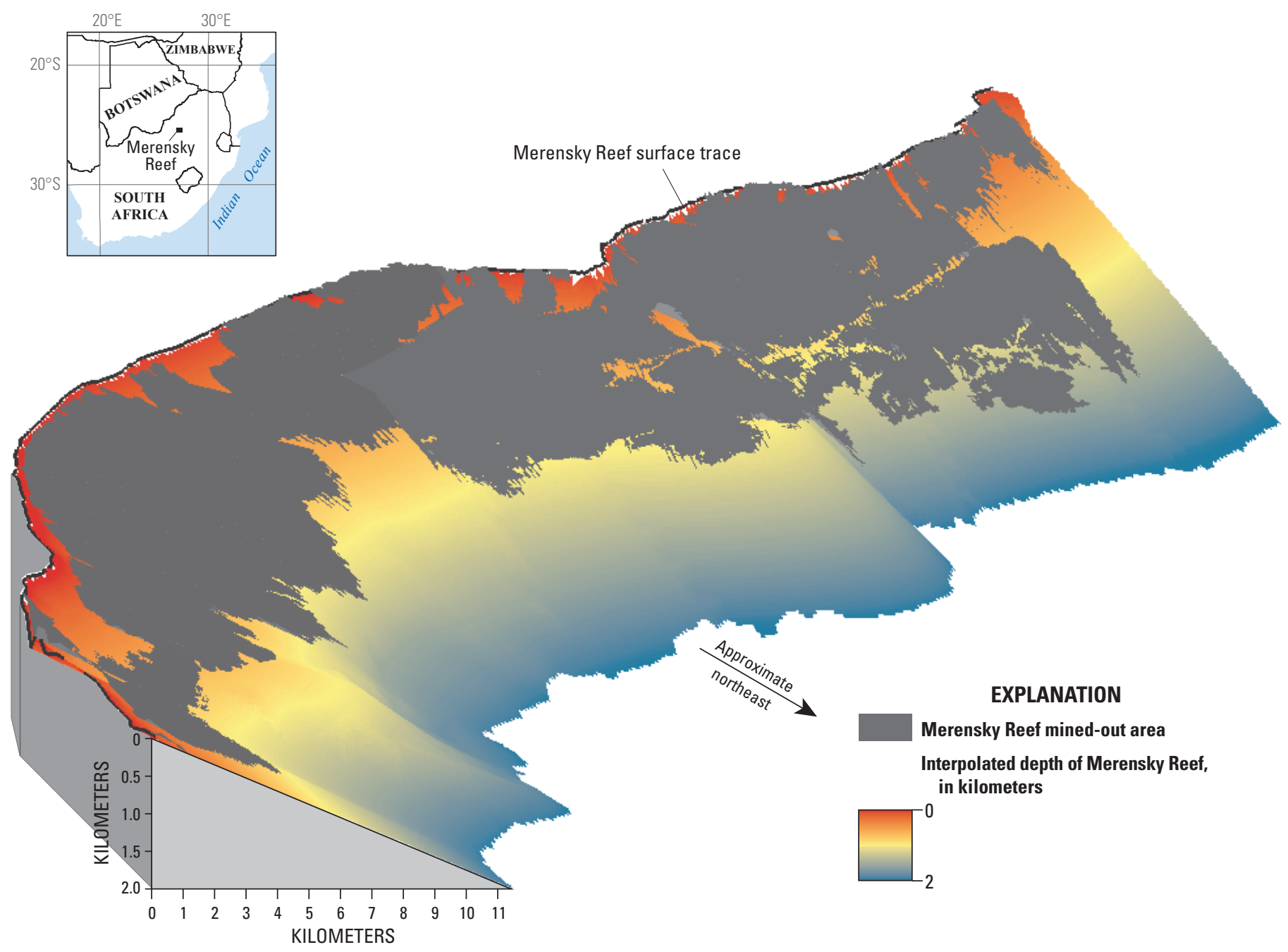

Figure N25. Three-dimensional block diagram showing the Merensky Reef interpolated down to 2 kilometers in the southern area of the western limb of the Bushveld Complex, South Africa. Mined out areas are shown in gray, and the Merensky Reef trace is shown as a black line. The Merensky Reef continues at depth beyond what is shown in this illustration.

could contain up to 6,900 metric tons of undiscovered platinum, palladium, and rhodium (Zientek and others, 2014).

Additional PGE resources in the Noril'sk-Talnakh area in Russia are difficult to assess. The extent of the orebodies for which resources are reported is not revealed in publicly accessible technical information released by the mining company. The northernmost mine in the Talnakh area, the Skalisty Mine, appears to be midway along the axis of the intrusion that hosts the massive sulfide orebodies (fig. N7 $A$ ). If existing maps, similar to the one shown in figure $\mathrm{N} 7 A$, are approximately correct, additional resources associated with massive sulfide orebodies in the Talnakh area could be present.

Roughly 305 metric tons of platinum and palladium have been produced from the J-M Reef in the Stillwater Complex in Montana, and drill-based estimates indicate that another 2,200 metric tons are present (U.S. Bureau of Mines,
1933-96; U.S. Geological Survey, 1997-2016; Abbott and others, 2011). Mining has progressed to depths of $1,800 \mathrm{~m}$ below the surface, but the bottom of the ore deposit has not been reached. Rough geologic estimates suggest that another 1,000 to 6,200 metric tons of platinum and palladium could be present at depth (Zientek, 1993; Zientek and others, 2002). As with the Bushveld Complex, the J-M Reef has been traced for longer distances along strike than down dip. The downdip projection of the J-M Reef is complicated by structural deformation associated with the uplift of the Beartooth Mountains. Gravity anomalies and inclusion suites in younger, cross-cutting intrusions, however, demonstrate that a portion of the complex is concealed at depth (Brozdowski, 1985; Kleinkopf, 1985). As a result, structural and geophysical models would be needed to constrain what rocks may be present at depth. 


\section{Undiscovered Reef-Type and Contact-Type Deposits}

Based on literature research, there are at least 200 layered intrusions in the world, although the actual number could be two to three times higher. An intrusion does not have to be large to have a reef-type deposit; intrusions as small as a few tens of kilometers in length with as little as $500 \mathrm{~m}$ of layered cumulates are known to host reef-type mineralization (table N6 at back of chapter; fig. N26). Well-explored intrusions have at the most 1- or 2-m-thick reef-type deposits (and several subeconomic occurrences) that occur in thousands of meters of layered rock. Many small intrusions could be evaluated for their reef-type potential to assess whether an economic deposit could be present.

For example, the identified PGE resources in Finland are 91 metric tons of platinum and 237 metric tons of palladium in seven reef-type and contact-type deposits. An assessment by the Geological Survey of Finland estimates that a mean number of 29 and 23 contact-type and reef-type deposits, respectively, occur in Finland. They estimate that the median contained metal contents would be 5,500 metric tons of platinum and 12,000 metric tons of palladium in the undiscovered contact-type and reef-type deposits (Rasilainen and others, 2010).

Undiscovered magmatic mineral deposits could be present in many areas of the United States and the world. The intrusions of the Duluth Complex, United States, and other smaller intrusive complexes of the Midcontinent Rift in the Lake Superior region have high potential to contain undiscovered copper-nickel-PGE sulfide deposits (fig. N15; Miller and others, 2002). In fact, recent exploration has dramatically expanded the mineral resource inventory of contact-type deposits along the western margin of the Duluth Complex. Exploration results have led to new exploration models, which indicate additional areas that may have the potential for undiscovered deposits. Furthermore, the Duluth Complex has many large layered intrusions that may have the potential to host reef-type PGE deposits. New models, new data, and tools for integration and visualization could result in discoveries of mineralized rocks.

Ernst and Buchan (2001) cataloged more than 300 LIP events worldwide; they determined that more than 100 LIP events have associated sill complexes or layered intrusions. All are prospective for the occurrence of magmatic mineral deposits. In the United States, Ernst and Buchan identified about 25 LIP events, of which several have sill complexes and layered intrusions. The obvious exploration targets for reeftype deposits in the United States are the Stillwater Complex in Montana and the dozens of intrusions that make up the Duluth Complex in Minnesota and associated rocks of the Keweenawan LIP. Other layered mafic intrusions with reeftype potential occur in the Wichita Mountains of Oklahoma,

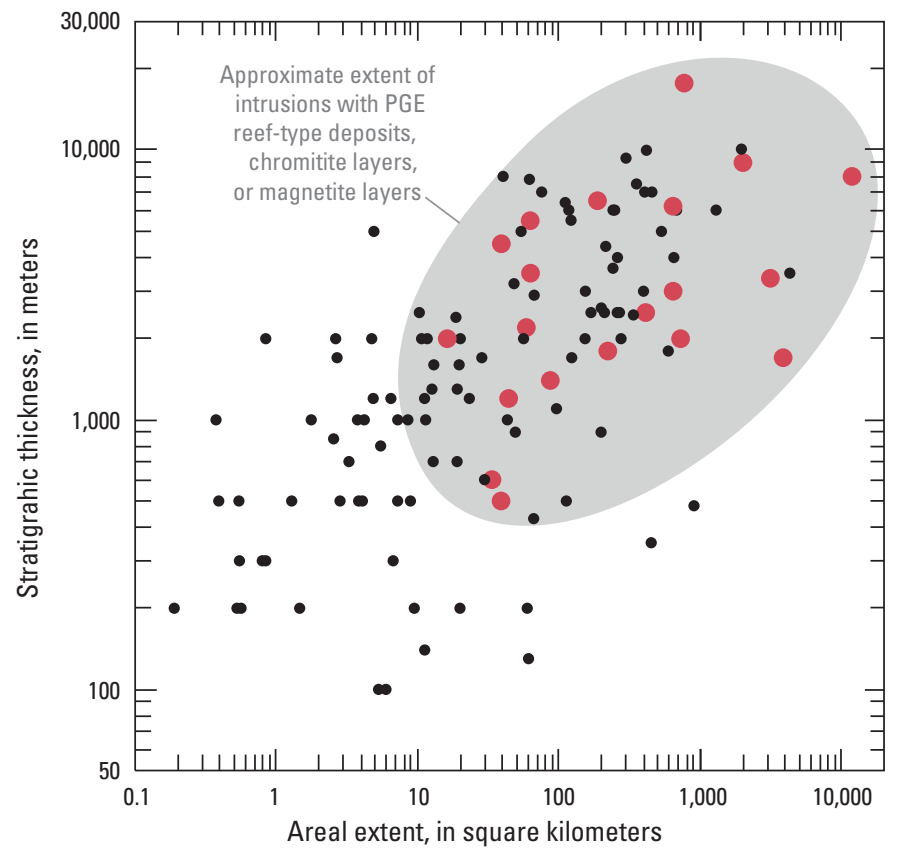

EXPLANATION

Intrusions with platinum-group-element (PGE) reef-type deposits, chromitite layers, or magnetite layers

- Intrusions with no known mineralization

Figure N26. Graph illustrating the exposed area and stratigraphic thickness of cumulates in more than 200 intrusions from around the world.

which are part of a Cambrian LIP. The Lake Owens Complex in Wyoming, which is a small layered intrusion, is also reported to have reef-type mineralization (Loucks, 1991). Other large layered intrusions are known from subsurface oil and gas exploration in west Texas and New Mexico; at present, they are too deep to be targets for mineral exploration (Keller and others, 1989; Kargi and Barnes, 1995; Adams and others, 1997).

To have a significant effect on global supply, a large-tonnage deposit would first have to be discovered. Large-tonnage reef-type deposits can occur only in large layered intrusions. A survey of the literature shows there are several large intrusions that do not have identified reef-type mineralization (such as the Tete Complex, the Dufek intrusion, the Molopo Farms Complex, the Windimurra Complex, and so on) (table N6). Some of the intrusions are poorly exposed and others have been intensely deformed and metamorphosed, which makes them difficult to explore for deposits. The economic risk associated with exploring these intrusions would be relatively high compared with identifying additional resources in extensions of known reef-type deposits. 


\section{Undiscovered Conduit-Type Deposits in the United States-Nikolai Greenstone and Eastern Wrangellia}

Several LIPs with sill complexes occur in the United States (Ernst and Buchan, 2001); however, one in particular stands out for its potential for undiscovered conduit-type nickel-copper-PGE mineralization (Hulbert, 1997; Hulbert and Stone, 2006; Schmidt and Rogers, 2007). The Wrangellia LIP is known from extensive flood basalts and related rocks of the Middle to Late Triassic Nikolai Greenstone that is part of the Wrangellia terrane accreted to the western margin of North America (Berg and others, 1972; Jones and others, 1972; Berg and others, 1978; Nokleberg and others, 1994; Plafker and Berg, 1994). The Wrangellia terrane can be traced discontinuously for more than 2,000 km from the Wrangell and Amphitheater Mountains in southern Alaska through Canada's southwestern Yukon Territory, to the Queen Charlotte and Vancouver Islands in British Columbia, Canada.

Sill-like mafic to ultramafic intrusive complexes in Wrangellia are the remnants of subvolcanic magma chambers that fed the thick, overlying flood basalts and picritic pyroclastics of the Nikolai Greenstone. A conduit-type deposit in the Wellgreen intrusion, Yukon Territory, contains a resource of 461 million metric tons grading 0.32 weight percent nickel, 0.26 weight percent copper, $0.4 \mathrm{ppm}$ platinum, $0.34 \mathrm{ppm}$ palladium, and $0.17 \mathrm{ppm}$ gold (McCracken, 2011; Carter and others, 2012).

Alaska's Amphitheater Mountains and the area of southcentral Alaska are also underlain by several mafic to ultramafic complexes that are part of the Nikolai LIP (fig. N27; Schmidt and Rogers, 2007; Glen and others, 2011). The largest and most exposed mafic to ultramafic sills include the Fish Lake and Tangle (FL-T) Complexes, which occur along the flanks of the Amphitheater Mountains synform. Smaller mafic to ultramafic complexes include Canwell, Eureka, and Rainy. The occurrence of picritic volcanic rocks (high-magnesium olivine basalt) near some of the larger mineralized ultramafic bodies is consistent with mineralized occurrences that have high nickel-to-copper ratios and elevated PGE concentrations. Grab samples from three different mafic to ultramafic complexes have extremely high metal concentrations, as follows: 2.0 weight percent nickel, 1.3 weight percent copper, and $7.9 \mathrm{~g} / \mathrm{t}$ PGE+gold+silver from Rainy; 13.6 weight percent nickel, 2.9 weight percent copper, and 26.0 g/t PGEs from Canwell; and 6.7 weight percent nickel, 1.0 weight percent copper, and $1.5 \mathrm{~g} / \mathrm{t}$ PGEs from Alpha (same as Fish Lake) (Pure Nickel, Inc., 2013).

\section{Undiscovered Platinum Placer Deposits in Alaska}

Undiscovered marine placer deposits could be associated with paleochannels or beach deposits in the Goodnews Bay region in Alaska. A geophysical survey indicates the presence of ultramafic rocks offshore, which could be a source of placer platinum (Barker and others, 1988; Barker and Lamal, 1989). Seismic analysis indicates that the bottoms of the paleochannels that drained these now-offshore ultramafic rocks are about 20 to $40 \mathrm{~m}$ deep and covered with modern sediments (Oommen, 2006; Oommen and others, 2008). Platinum may have accumulated in marine sand bars that are aligned parallel or subparallel to the current Alaskan coastline (Oommen, 2006; Oommen and others, 2008). Assuming that the sand bars represent submerged paleobeaches exposed during periods of glaciation in the Pleistocene Epoch, intensified wave sorting and concentration of heavy minerals (including entrained platinum grains) may have taken place. Spatial distribution patterns of platinum and sediments offshore of the Goodnews Bay Complex suggest relatively high platinum concentrations near Goodnews Bay and Carter Bay (Oommen, 2006; Oommen and others, 2008).

Schmidt and others (2007) delineated a permissive tract (fig. N19A) for placer PGE-gold deposits hosted in Quaternary unconsolidated alluvial and marine sediments that includes onshore regions and areas up to $10 \mathrm{~km}$ offshore that are downstream of known mafic to ultramafic complexes within the Goodnews Bay and Togiak terranes (Hoare and Coonrad, 1978; Decker and others, 1994). They estimate that the tract has a 90 percent probability of containing at least 1 metric ton of platinum and a 10 percent probability of containing at least 17 metric tons; the mean and median estimates are 5 and 7 metric tons, respectively.

\section{Metals in Stored Waste Products}

PGEs may also be present in material discarded during the mining and beneficiation of magmatic ore deposits. When ore materials are processed to recover the PGEs, some losses always occur; in other words, it is impossible to recover 100 percent of the metal in the mined material. For example, tailings derived from processing ores from the Noril'skTalnakh area in Russia may contain 800 to 1,000 metric tons of PGEs; an additional 100 metric tons of PGEs may be present in stored pyrrhotite concentrates and iron cakes (Petrov and others, 2013). Some of the metals in stored waste products could be recovered if appropriate technologies are developed. For example, ultrafine grinding techniques are currently being used to reprocess tailings from the Merensky Reef mines in South Africa (Buys and others, 2013). 

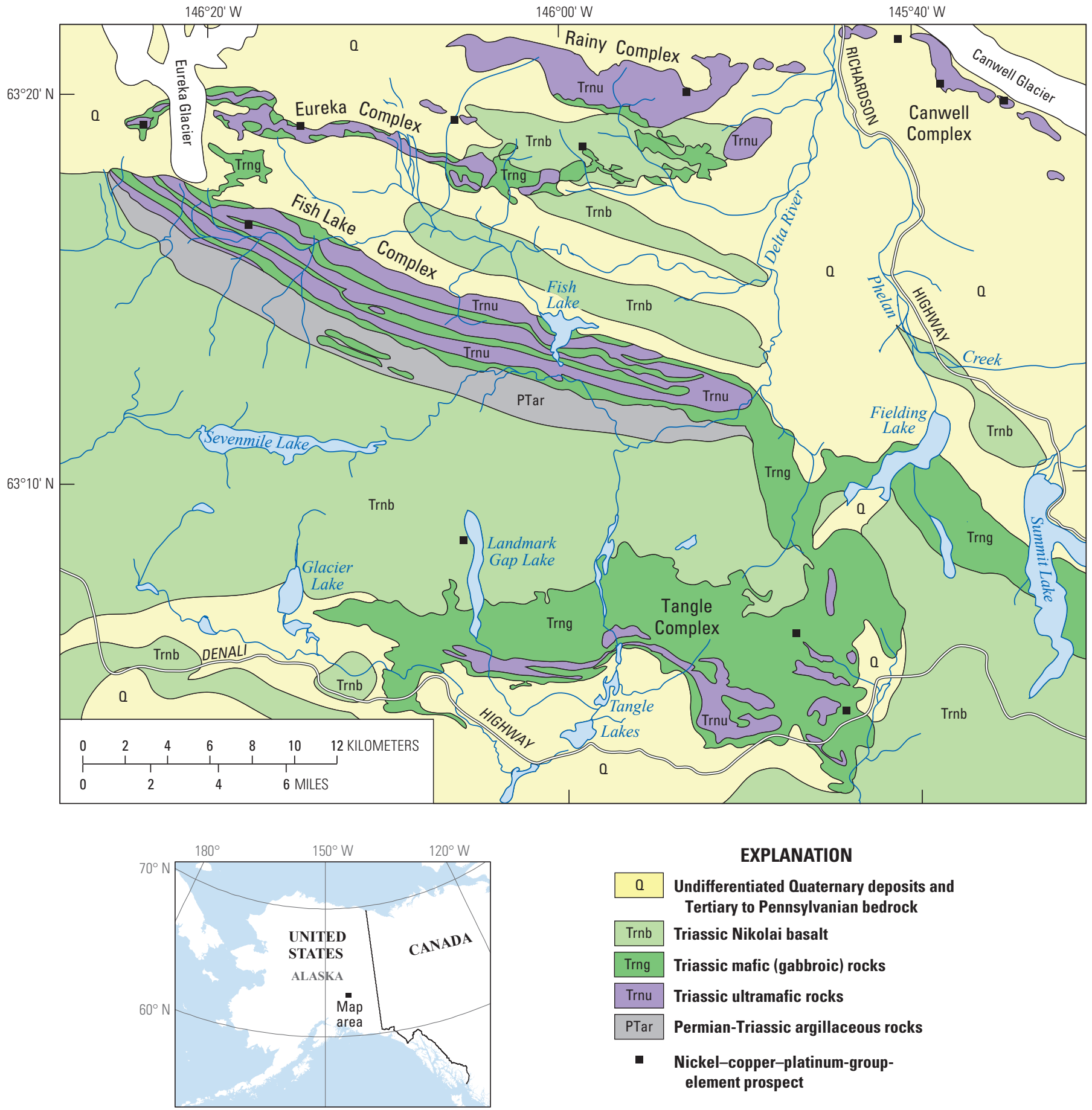

\section{EXPLANATION}

0 Undifferentiated Quaternary deposits and Tertiary to Pennsylvanian bedrock

\begin{tabular}{|c|c|}
\hline Trnb & Triassic Nikolai basalt \\
\hline Trng & Triassic mafic (gabbroic) rocks \\
\hline Trnu & Triassic ultramafic rocks \\
\hline PTar & Permian-Triassic arqillac \\
\hline
\end{tabular}

- Nickel-copper-platinum-groupelement prospect

Figure N27. Geologic map of the Amphitheater Mountains and south-central Alaska showing the location and names of mafic-ultramafic complexes that are part of the Nikolai large igneous province (Schmidt and Rogers, 2007). 


\section{Exploration for New Deposits}

The methods of locating PGE deposits can vary. In very rare cases, PGE-enriched sulfide mineralization has been found by panning. For example, the Merensky Reef of the Bushveld Complex, South Africa (fig. N9), was discovered in 1924 as the result of panning in a dry river bed and finding platinum minerals in the concentrate (Cawthorn, 1999). In most cases, chemical analysis of samples is required to identify PGE-enriched rocks. Because of the refractory nature of PGEs and their low concentration in most materials, an analytical technique that preconcentrates PGEs before analysis and ensures complete digestion of the sample is required. The preferred method to analyze for PGEs is fire assay.

A practical and effective exploration approach is to look for anomalous concentrations of copper, platinum, and palladium in residual or transported material derived from a larger volume of rock, such as soil, stream sediments, and talus fines (Cameron and Hattori, 2005). Soil chemistry has been used to delineate mineralized rocks in the Platreef of the Bushveld Complex (Frick, 1985). The J-M Reef of the Stillwater Complex (fig. N13) was discovered in 1974 by analyzing soil and talus fines for platinum and palladium (Conn, 1979; Zientek and others, 2005). Contact-type mineralization in the Duluth Complex (fig. N15) is currently being explored using regional geochemical surveys of glacial till (Duluth Metals Ltd., 2011).

Surface-water geochemistry led to the discovery of the ore deposits in the Noril'sk-Talnakh area in Russia (figs. N3 and N6; Kunilov, 1994). A surface water geochemical survey showed elevated concentrations of $\mathrm{SO}_{4}{ }^{2-}$ in samples from the Talnakh River. This led to the discovery of mineralized boulders in the area, which were traced to the base of the Kharayelakh Mountains. A study of talus along the slope of Otdel'naya Mountain led to the discovery of mineralized outcrops.

Geophysical methods used in PGE exploration map physical property contrasts, which primarily indicate the presence of magnetite, silicate minerals, and sulfide minerals that may be associated with PGE mineralization (Balch, 2005). If the PGEs are associated with base-metal sulfide minerals that have some degree of interconnection in the rock (and are electrically conductive), airborne and ground electromagnetics and induced polarization surveys can be used to detect mineralized rocks. High-resolution aeromagnetic surveys can be used to map igneous layering and tectonic structures (Campbell, 2006) but generally do not give direct indication of mineralized rock. Gravity studies are used to determine the subsurface extent of rocks with variable density and are particularly well suited to map and model the extent and volume of mafic and ultramafic igneous rocks (Webb and others, 2004). Once a rock layer that contains reef-type mineralization has been identified, seismic studies can be used to map the subsurface extent of the rocks (Davison and Chunnett, 1999; Chunnett and Rompel, 2004).
Lithogeochemical studies can be used to focus exploration activities (Maier and Barnes, 2005). For example, changes in the ratio of PGEs to sulfur or copper in rocks can be used to target specific intervals in cumulate stratigraphy where reef-type PGE mineralization could be present. In layered intrusions, nickel depletion in olivine is thought to indicate indirectly the presence of magmatic sulfide mineralization. Metal depletion in lavas flows is thought to indicate the presence of sulfide mineralization in the sills and dikes that served as feeders to the flows.

High-density drilling and sampling are required to delineate mineral resources and reserves in PGE deposits. For the J-M Reef, drilling on 15-m spacing is used to define proven mineral reserves; probable mineral reserves are delineated by projecting data $300 \mathrm{~m}$ from drill holes (Abbott and others, 2011). In the reef-type deposits in the Bushveld Complex, South Africa, measured mineral resources are defined with holes spaced 250 to $300 \mathrm{~m}$ apart, indicated resources are defined with holes spaced 500 to $600 \mathrm{~m}$ apart, and inferred mineral resources are defined with holes spaced 800 to 2,000 m apart. By comparison, massive sulfide ores in the Noril'sk-Talnakh area, Russia, are explored on a 32- by 60-m rectangular grid (Kunilov, 1994).

\section{Environmental Considerations}

The mineralogy of the ore and waste material associated with reef-type, contact-type, and conduit-type deposits are similar. Common sulfide minerals include chalcopyrite, pentlandite, and pyrrhotite. Secondary phases that typically form from primary sulfide minerals include covellite, goethite, gypsum, jarosite, marcasite, native sulfur, and pyrite (McGregor and others, 1998; Johnson and others, 2000). Common primary gangue minerals include chromite, olivine, plagioclase, and pyroxene. Alteration products include chlorite, magnetite, serpentine, talc, and minor amounts of carbonate and clay minerals.

The abundance of sulfide minerals defines the environmental and geologic characteristics of PGE-enriched magmatic sulfide deposits. The high proportion of sulfide minerals distinguishes some conduit-type deposits from reefand contact-type deposits. The overall pyrrhotite content of ore, waste rock, and tailings determines their acid-generating potential. Acid generated by the oxidative weathering of pyrrhotite can attack associated ore sulfide minerals and gangue silicate minerals, releasing a variety of potentially toxic elements - particularly cobalt, copper, iron, manganese, nickel, and, to a lesser extent, aluminum, cadmium, chromium, lead, and zinc to solution or to secondary solid phases (McGregor and others, 1998; Johnson and others, 2000). Massive ores characteristic of some conduit-type deposits have greater than 50 volume percent sulfide minerals and pose a greater challenge for mining and processing the ores without causing environmental problems. Both the low-sulfide 
reef-type and contact-type deposits have significantly lower sulfide contents, usually less than a few volume percent. Therefore, acid generation in mine wastes is less of a challenge to manage.

\section{Sources and Fate in the Environment}

The abundance of PGEs in the upper continental crust ranges from tens to hundreds of parts per trillion (ppt); platinum is the most abundant, followed by palladium, osmium, ruthenium, iridium, and rhodium (table N7; Taylor and McLennan, 1995; Park and others, 2012). Background PGE concentrations are also low in other environmental media, such as water, sediment, soil, and plants.

Experimental studies suggest that the maximum solubility of platinum in water at room temperature $\left(25^{\circ} \mathrm{C}\right)$ under oxygenated conditions ranges between 0.02 and $195 \mathrm{ppb}$, depending upon the $\mathrm{pH}$ of the water (Wood, 1991; Azaroual and others, 2001). The solubility of palladium in water at room temperature $\left(25^{\circ} \mathrm{C}\right)$ under oxygenated conditions ranges between 1 and 3,400 ppb, depending upon the $\mathrm{pH}$ of the water (Wood, 1991). Because of its greater solubility, palladium is more mobile in the environment than platinum.

PGE concentrations in water are generally in the $10^{-2} \mathrm{ppt}$ range. Rhodium $(0.082 \mathrm{ppt})$ has the highest mean concentration in seawater, followed by palladium ( $0.062 \mathrm{ppt})$, platinum (0.026 ppt), and osmium (0.005 ppt); ruthenium and iridium are present well below the ppt range (Bruland and Lohan, 2003). Platinum concentrations range from 0.22 to $78,000 \mathrm{ppt}$ in surface water and from 3 to $38 \mathrm{ppt}$ in groundwater (Ravindra and others, 2004).

Environmental baseline studies generally show low concentrations of PGEs and trace elements in water near undeveloped deposits. In the vicinity of the contact-type
NorthMet deposit in northern Minnesota, surface water downstream of the deposit in the Partridge River watershed has neutral $\mathrm{pH}$ (7.0), a low dissolved sulfate concentration (7.2 ppm), and moderate alkalinity ( $31 \mathrm{ppm}$ calcium carbonate $\left.\left[\mathrm{CaCO}_{3}\right]\right)$ and hardness $\left(30.3 \mathrm{ppm} \mathrm{CaCO}_{3}\right)$. Dissolved platinum and palladium concentration are below the detection limit $(<25 \mathrm{ppb})$, and the concentrations of other trace elements are low (table N8 at back of chapter; Minnesota Department of Natural Resources and the U.S. Army Corps of Engineers, 2009). Near the buried Eagle deposit, which is a conduit-type deposit in northern Michigan, maximum concentrations of iron (190 ppb), nickel (59 ppb), and zinc (88 ppb) in groundwater near the deposit reflect the presence of the orebody, whereas maximum concentrations of copper $(<5 \mathrm{ppb})$ and cobalt $(<10 \mathrm{ppb})$ are below their detection limits. In contrast, the concentrations of copper, nickel, and other trace elements in surface waters over the buried deposit are indistinguishable from those from regional water samples (Kennecott Eagle Minerals Co., 2006).

In fluvial and pelagic-marine sediment away from any known deposits, total PGE concentrations are less than a few tens of ppb (table N7). Platinum and palladium are found in higher concentrations than are (in decreasing order of abundance) ruthenium, iridium, osmium, and rhodium.

Fuchs and Rose (1974) investigated the geochemical behavior of platinum and palladium in the weathering cycle in soils around the Stillwater Complex in Montana. They found that palladium was depleted in the surface soil horizons but was concentrated at depth, reaching a maximum concentration of approximately $40 \mathrm{ppb}$. Platinum did not show systematic trends with depth; a maximum concentration of approximately $180 \mathrm{ppb}$ was recorded. The differences in the behavior of palladium and platinum in soils reflects the higher solubility of palladium in water compared with that of platinum in water (Fuchs and Rose, 1974).

Table N7. Platinum-group-element concentrations in samples of upper crust, loess, river sediment, and marine pelagic sediment. [n.d., no data]

\begin{tabular}{|c|c|c|c|c|c|c|c|}
\hline \multirow{2}{*}{ Material } & Platinum & Palladium & Ruthenium & Iridium & Osmium & Rhodium & \multirow{2}{*}{ Reference(s) } \\
\hline & \multicolumn{6}{|c|}{ (part per billion) } & \\
\hline $\begin{array}{l}\text { Upper continental } \\
\text { crust }\end{array}$ & 0.599 & 0.526 & 0.03 & 0.022 & 0.05 & 0.018 & $\begin{array}{l}\text { Taylor and McLennan (1995); } \\
\text { Park and others (2012) }\end{array}$ \\
\hline Loess (China) & 0.751 & 0.546 & 0.03 & 0.023 & n.d. & 0.018 & Park and others (2012) \\
\hline $\begin{array}{l}\text { River sediment } \\
\text { (Mölndal River, } \\
\text { Sweden, and } \\
\text { Stour River, } \\
\text { England) }\end{array}$ & $\begin{array}{l}<0.29 \text { to } \\
53.9\end{array}$ & $\begin{array}{l}0.08 \text { to } \\
38.7\end{array}$ & $\begin{array}{l}<0.15 \text { to } \\
3.73\end{array}$ & $\begin{array}{l}<0.03 \text { to } \\
2.69\end{array}$ & n.d. & $\begin{array}{c}<0.11 \text { to } \\
9.4\end{array}$ & $\begin{array}{l}\text { Ravindra and others (2004); } \\
\text { Moldovan and others (2001); } \\
\text { de Vos and others (2002) }\end{array}$ \\
\hline $\begin{array}{l}\text { Marine pelagic } \\
\text { sediment }\end{array}$ & $\begin{array}{c}0.4 \text { to } \\
21.9\end{array}$ & $\begin{array}{c}1.2 \text { to } \\
9.4\end{array}$ & $\begin{array}{c}<0.2 \text { to } \\
2.2\end{array}$ & $\begin{array}{c}<0.2 \text { to } \\
1.2\end{array}$ & $\begin{array}{c}<0.05 \text { to } \\
0.81\end{array}$ & n.d. & Goldberg and Koide (1990) \\
\hline
\end{tabular}


The results of an exploration program illustrate the natural background variation of platinum and palladium in a layered intrusion that hosts a major reef-type deposit. Following the studies by Fuchs and Rose, more than 10,900 samples of soil and talus fines were collected and analyzed for platinum and palladium as part of the exploration program that led to the discovery of the J-M Reef at the Stillwater Complex (Conn, 1979; Zientek and others, 2005). Palladium was below the detection limit for 14 percent of the locations; almost one-half of the samples had platinum concentrations that were below the detection limit. For most of these samples, the detection limit for palladium and platinum was $2 \mathrm{ppb}$ and $20 \mathrm{ppb}$, respectively. The median values for samples in the study above the detection limit were $8 \mathrm{ppb}$ and $20 \mathrm{ppb}$ for palladium and platinum, respectively. Maximum values measured for palladium and platinum were $6.4 \mathrm{ppm}$ and 5.76 ppm, respectively.

Platinum and palladium data are characterized by positive-skewed, multimodal distributions. More than 95 percent of the samples belong to a population consisting of unmineralized material with less than 30 to $40 \mathrm{ppb}$ palladium and less than 40 to $50 \mathrm{ppb}$ platinum. The remaining approximately 460 samples appear to be made up of two populations. The range of values for the largest population in the remaining 5 percent varies from about $40 \mathrm{ppb}$ to $200 \mathrm{ppb}$ palladium and about 50 to about $200 \mathrm{ppb}$ platinum. About 50 samples make up the third population and consist of material with more than $200 \mathrm{ppb}$ platinum or palladium.

Biogeochemical surveys show that platinum and palladium can concentrate in plants near mineralized outcrops. Riese and Arp (1983) conducted a geochemical orientation survey of the J-M Reef in the Stillwater Complex and found accumulations of platinum in stems of Douglas-fir (Pseudotsuga menziesii) up to thousands of parts per billion in ashed samples. In the northern forests of Saskatchewan, Canada, platinum and palladium tend to be concentrated in the twigs and trunks of black spruce (Picea mariana) and jack pine (Pinus banksiana) and in the stems of Labrador tea (Rhododendron groenlandicum). Spruce was sampled close to a worked-out nickel-copper deposit in northern Saskatchewan that contained 3,000 ppb platinum and 6,000 ppb palladium. The ashed twigs yielded up to $880 \mathrm{ppb}$ platinum and $1,350 \mathrm{ppb}$ palladium compared with background levels of below $10 \mathrm{ppb}$ platinum and $2 \mathrm{ppb}$ palladium (Dunn, 1986). Coker and others (1991) found greater enrichment of palladium than of platinum in vegetation around several PGE deposits in Canada-some that had been mined and some that had not been mined.

Anthropogenic sources of PGEs in the environment include catalytic converters used in modern automobiles (Ek and others, 2004; Ravindra and others, 2004; Wiseman and Zereini, 2009), platinum-based chemotherapy drugs (Ravindra and others, 2004), and smelter emissions (Chen and others, 2009). During the release of exhaust gases from automobile engines, the catalytic converters are chemically and physically stressed and release PGE-containing particulate matter. Most of the PGEs in the particles are in the metallic state, but about 1 percent is in an oxidized form that could be bioavailable (Ravindra and others, 2004). Concentrations of PGE particles are found in roadside dust, soils, and water. In platinumbearing drugs that are used to treat cancer, the platinum is excreted by the patients following treatment and ends up in the hospital sewage. The contribution of PGEs to the environment through this method is minor, however, compared with that from catalytic converters (Ravindra and others, 2004). Tiny amounts of osmium ( 0.25 to 23 femtograms per gram of water; 1 femtogram is $10^{-15}$ grams) are found in rainwater and snow from around the world (Chen and others, 2009). The most likely sources of this metal are smelters that process PGE ores. The osmium concentrations are so low that they are difficult to analyze; however, it is possible that the global appearance of osmium could someday be used as an environmental tracer.

\section{Platinum-Group-Element Mining and Mineral- Processing Methods}

Selective underground mining techniques are used for PGE deposits that occur in narrow reefs, such as those in the Bushveld Complex (South Africa) and the Stillwater Complex (Montana). The underground mining is performed by using either handheld pneumatic drills or mechanized drills to bore holes in the ore horizon, which are then filled with explosives. After blasting, the ore is removed from the mining stope and transported to the surface for further processing. Open pit mining is used for deposits in which the PGEs occur in greater thicknesses and at shallow depth, such as in the Lac des Iles Mine in Canada and the Platreef of the Bushveld Complex.

After ore is removed from the mines, it is crushed and ground to reduce the particle size and free the PGE-containing minerals from the rock matrix. The ore is then concentrated by using froth flotation circuits. For flotation, the ground rock particles are mixed with water and various reagents and air is pumped through the liquid, creating bubbles to which the PGE-containing minerals adhere. These bubbles float to the surface of the flotation vats and are removed as froth. The material is reground and refloated to produce a concentrate of nickel-iron-copper-PGE sulfide minerals for further processing. The greatest losses of PGEs occur in the early stages of processing, including crushing, milling, and froth flotation, owing to the diversity of PGE mineralogy. Much research is devoted to increasing PGE recovery rates in these early stages.

The concentrate is dried and then smelted in an electric arc furnace at temperatures that can exceed $1,500{ }^{\circ} \mathrm{C}$. During smelting, the concentrate forms a liquid, which separates into two layers. A matte containing the valuable metals is separated from a silicate- and oxide-rich slag, which is discarded. At the Stillwater Mining Co. smelter, the gases released from 
smelting operations undergo a gas-to-liquid scrubbing process, which removes approximately 99.8 percent of the sulfur dioxide. The sulfur dioxide is converted to gypsum, which is sold to local farmers for use as a soil amendment.

After smelting, the PGE-rich matte is transferred to converters, through which air is blown to remove iron and sulfur. The converter matte is processed at the base-metals refinery to separate the base metals from the PGEs by selective leach processing. The final stage is PGE refining by various hydrometallurgical techniques, including solvent extraction, precipitation, and dissolution using chloride solutions, in which the six PGEs are separated from each other to a purity of more than 99.99 percent. The refined PGEs can be produced in various forms, including as ingots, grains, or a fine powder known as "sponge."

The chromium-rich ores of the Bushveld Complex's UG2 Chromitite present special difficulties for beneficiation. The high chromium content of the ores requires especially high temperatures for smelting, and the low sulfide content both increases the matte viscosity and lowers the amount of matte formed. A processing technique, known as ConRoast, has been employed by some Bushveld processors specifically for use with high-chromium PGE ores. The ConRoast technique removes sulfur from the concentrate by roasting the ore at high temperatures in oxidizing conditions followed by smelting in a direct-current arc furnace in reducing conditions, which uses an iron-based alloy as a collector of cobalt, copper, nickel, and PGEs. The ConRoast technique can be used for concentrates containing any amount of chromite (Jones, 2002).

Ores from the Duluth Complex (Minnesota) present another challenging processing problem. Their low-grade nature makes smelting inefficient and uneconomic. A hightemperature chloride-assisted pressure-leaching process, known as PLATSOL ${ }^{\mathrm{TM}}$, has been developed to process the Duluth ores. The PLATSOL ${ }^{\text {TM }}$ process is an alternative to smelting and is capable of processing low-grade PGE ores. The nickel-copper-PGE ore concentrates are processed in an autoclave in an oxidizing environment in which PGEs, as well as gold, are solubilized and can be recovered directly after leaching by adsorption or precipitation with sulfide ions. Finally, base-metal sulfides are recovered either by precipitation, ion exchange, or solvent extraction-electrowinning (Baxter and others, 2005).

\section{Mine Waste Characteristics}

The majority of solid mine waste includes waste rock, mill tailings, slag, and smelter dust. Waste rock is uneconomic rock that must be removed to access the ore and is disposed of on site. It can also be used for construction on site if tests determine that it will not generate acid-rock drainage when it is exposed to the atmosphere and water. Tailings, which is the waste material from processing ore, can be pumped as slurry or trucked dry to a tailings storage facility on site. Tailings storage facilities are typically impoundments surrounded by a retaining dam. Tailings can also be disposed of underground in mined-out portions of the mine. The crushing and milling process increases the porosity of the solid waste and thus its volume by a factor of approximately two, which means that only about one-half of the waste from ore processing can be returned underground. Smelter slag, which is glassy waste matter separated from metals during the refining of ore, also has both physical and chemical characteristics of environmental concern and is typically held in storage facilities. Slag is also used in some mining and construction applications. Smelters produce gaseous emissions that may contain particulate material (smelter dust). If the emissions are not treated before the gases are vented to the atmosphere, the particulate material will settle near the smelter. For most modern smelting facilities, the gaseous emissions are treated to remove particulates, which are reprocessed to recover metals or put into a storage system.

Waste rock and tailings are usually found at all mines, but their proportions vary based on the mining method. The amount of waste rock is significantly greater at open pit mines than at underground mines. Reef-type deposits are generally mined by underground methods because of the narrow width of the ore horizon. Contact-type and conduit-type ores are mined by either open pit or underground methods, depending upon the geometry and depth of the orebodies.

\section{Acid-Base Accounts}

Metals and many other trace elements tend to be more soluble at low $\mathrm{pH}$ than at neutral or high $\mathrm{pH}$. Therefore, the acid-generating or acid-neutralizing potentials of waste rock, tailings, and other solid waste material help determine the possible environmental risk of mineral resource development. The balance between the acid-generating and the acidneutralizing potential of rocks and mine waste is expressed as an "acid-base account" (Price, 2009; International Network for Acid Prevention, 2011). The release of acid is primarily related to the presence of pyrrhotite in the rocks and waste. The presence of carbonate minerals, such as calcite, and some silicate minerals, such as feldspar, olivine, or pyroxene, in rocks and wastes can neutralize acidic solutions. Acid-base accounting values are commonly expressed in terms of kilograms of calcium carbonate per metric ton $\left(\mathrm{kg} \mathrm{CaCO}_{3} / \mathrm{t}\right)$ of waste material.

\section{Acid-Base Accounts for Reef-Type and Contact-Type Deposits}

Acid rock drainage from reef-type and contact-type deposits is unlikely because the ores and their host rocks contain low proportions of sulfide minerals. Jambor and others (2000) proposed a threshold of 0.3 weight percent sulfur present in sulfide minerals for acid generation. The sulfur content of ore in the J-M Reef at the Stillwater Complex 
in Montana ranges from 0.13 to 0.49 weight percent, with concentrations in tailings ranging from 0.05 to 0.08 weight percent. The sulfur content of the waste rock ranges from 0.01 to 0.04 weight percent (table N9 at back of chapter). Similarly, the ores and host rocks for the UG2 Chromitite, the Merensky Reef, and the Platreef deposits have low sulfur concentrations (Wilson and Chunnett, 2006; Naldrett and others, 2009). Acid-base accounting studies, leach tests, and site monitoring demonstrate that there is limited potential for the generation of hazardous metal leachates from ores, waste rocks, or tailings from most reef-type and contact-type deposits (table N9).

\section{Acid-Base Accounts for Conduit-Type Deposits}

For some conduit-type deposits with massive ores, the ore is processed to separate out and produce concentrates of iron-, copper-, and nickel-bearing sulfide minerals; the concentrated material is then further processed to extract the copper and nickel metals, and the iron-bearing sulfide minerals, mainly pyrrhotite, are discarded as waste. This process results in waste material with high acid-generating potential; the presence of minor amounts of carbonate minerals in the ore assemblage and the lower reactivity of the neutralizing minerals, such as olivine and pyroxene, offer minimal shortterm acid-neutralizing potential. The Eagle deposit in northern Michigan has the potential to generate acid leachate similar to that found in mineralogically similar tailings from Sudbury, Ontario, Canada (McGregor and others, 1998; Johnson and others, 2000). Johnson and others (2000) documented the generation of low $\mathrm{pH}$ (down to 3 ) waters with high dissolved concentrations of iron (up to $9,800 \mathrm{ppm}$ ), sulfate (up to 2,400 ppm), aluminum (up to 1,130 ppm), and nickel (up to 698 ppm) in groundwater in the tailings pile at the Nickel Rim Mine at Sudbury, Ontario, Canada. Copper (up to $3.5 \mathrm{ppm}$ ) and cobalt (up to $2.5 \mathrm{ppm}$ ) were also significant constituents.

\section{Air Quality Assessments}

An air quality assessment of the heavily industrialized western part of the Bushveld Complex, where the Merensky Reef and the UG2 Chromitite are mined, found that sulfur dioxide, nitrous oxide, and carbon monoxide concentrations are at acceptable levels using South African and European air quality standards (Venter and others, 2012). The major contributing sources were high-stack industry emissions for sulfur dioxide (metallurgical complexes and smelters), and household combustion for nitrous oxide and carbon monoxide. The levels of ozone and $\mathrm{PM}_{10}$ frequently exceeded standards $\left(\mathrm{PM}_{10}\right.$ refers to the total mass concentration of particulate matter up to 10 micrometers $[\mu \mathrm{m}]$ in size). Ozone is related to regional sources (wildfires, and coal and wood combustion for cooking and heating). The source of $\mathrm{PM}_{10}$ was identified as local household combustion (Hirsikko and others, 2012; Venter and others, 2012).
Mining operations in the Noril'sk-Talnakh area of Russia emit large amounts of sulfur dioxide and nickel and other metals (Council on Ethics, 2009; Bellona Foundation, 2010). According to the Norwegian Government's Council on Ethics for the Government Pension Fund-Global, atmospheric emissions of sulfur dioxide, which lead to acid rain, are about 2,000,000 metric tons per year, and atmospheric emissions of copper, nickel, and cobalt are conservatively estimated to be about 500, 450, and 50 metric tons per year, respectively. Smelting operations release metals into the atmosphere in the form of dust or particulates. Smelter emissions have been shown to cause death or significant damage to vegetation up to $200 \mathrm{~km}$ from the mining operations.

\section{Human Health Concerns}

The metallic forms of PGEs are generally considered to be inert. Health hazards specifically related to PGEs affect only individuals who are occupationally exposed to manmade PGE compounds, especially workers in preciousmetal refineries. Platinum-based drugs, such as cisplatin and carboplatin, are used in cancer treatment. Broader human health effects of PGEs appear to be limited because of the low concentrations of PGEs in the environment (Hoppstock and Sures, 2004). Ravindra and others (2004) and Hoppstock and Sures (2004) reviewed human health risks associated with PGEs, and Kielhorn and others (2002) reviewed the human health effects of palladium specifically. The more significant human health risks associated with PGE mining are related to the trace elements associated with PGE deposits.

As discussed in a previous section, the mining operations at the Noril'sk-Talnakh area in Russia affect air quality; surface and groundwater are also affected by the industrial activities. Respiratory diseases and various forms of cancer have been shown to be more prevalent in the local population of the Noril'sk-Talnakh area than in other regions of Russia (Council on Ethics, 2009). Industrial activity in this area has been shown to be related to increased incidences of acute respiratory illness and a higher prevalence of oncological disease, particularly lung cancer, and may be related to other possible negative health effects, such as weakening of the immune system, reproductive health issues, an increase in the rate of disease in children, and reduced life expectancy (Council on Ethics, 2009).

\section{Ecological Health Concerns}

The risks to the ecosystem from mining PGEs and associated minerals are mainly those related to acid mine drainage, which primarily affects aquatic environments. The surface water chemistry downstream from platinum mine waste dumps in Zimbabwe was investigated by Meck and others (2006). The surface water in the vicinity of platinum dumps was found to be near neutral or to have slightly alkaline $\mathrm{pH}$ and to contain concentrations of chromium, cobalt, copper, 
lead, and nickel that exceeded chronic surface-water criteria established by the U.S. Environmental Protection Agency (Suter, 1996; U.S. Environmental Protection Agency, 2009). Differences between upstream and downstream sample sites were most noticeable for nickel and approached a difference of $500 \mathrm{ppb}$.

Ecological risks can also be associated with soils and mill tailings. The toxicity of rehabilitated and nonrehabilitated mill tailings from reef-type deposits in South Africa to earthworms (Eisenia fetdia) was investigated by Jubileus (2008) and Maboeta and others (2008) using laboratory bioassay techniques. Sublethal impairment of earthworms (that is, effects on the growth and hatching success of cocoons) in soil samples decreased with distance from the tailing storage facilities. Anomalous concentrations of chromium, copper, nickel, and zinc were found in the tailings relative to the regional background soils. Wahl and others (2012) reached similar conclusions based on mesofauna surveys from the same tailing storage facilities.

Studies of soil and grass show anthropogenic platinum enrichment near mines in the Bushveld Complex. Thousands of soil and stream sediment samples collected at the Bushveld Complex show anomalous concentrations of precious metals related to bedrock sources and mining areas (Wilhelm and others, 1997). The results of the soil and stream sediment surveys mapped two bedrock sources of PGEs that are concordant to magmatic layering in the Bushveld Complex. The survey also mapped large anomalies near the locations of the large PGE mines in the western part of the Bushveld Complex; anomalies near the mines exceed 200 ppb PGEs. Rauch and Fatoki (2013) found about 700 ppb platinum in soils at a smelter. The maximum concentration in grass was $256 \mathrm{ppb}$ platinum, again found at the smelter.

\section{Carbon Footprint}

The PGEs and their mining have several links to carbon cycling in the environment. One of the most important uses of PGEs is in catalytic converters (Loferski, 2012a, b), which help to limit the amount of carbon and nitrogen gases and other air pollutants that enter the environment through vehicle exhaust. Fuel cells are an emerging energy technology. Proton exchange membrane (PEM) fuel cells use hydrogen as fuel, combining it with oxygen to form water; these fuel cells rely on platinum catalysts (Mehta and Cooper, 2003).

The trend towards the mining of lower grade ore in existing mines is expected to have a negative effect on greenhouse gas emissions. Lower grade ores require more energy to produce a unit of PGEs than do higher grade ores. The trend towards increased greenhouse gas emissions per unit of PGEs produced (measured in tons of carbon dioxide $\left[\mathrm{CO}_{2}\right]$ per kilogram of PGEs) over time is evident in data from
South Africa that date back to 2002 (Glaister and Mudd, 2010). In 2002, unit greenhouse gas emissions varied from about 20 to 40 metric tons for different mine properties. In 2008, the range of values increased to about 30 to 65 metric tons.

The calcium- and magnesium-rich silicate minerals common in mine wastes from PGE deposits represent an important sink for atmospheric carbon dioxide because these minerals react fairly readily with this greenhouse gas. The potential for mineral carbonation of PGE tailings was evaluated by Vogeli and others (2011). They ranked South African PGE tailings in terms of their carbonation potential on the basis of their mineralogy and the grain size and found that finer-grained, more olivine-rich, and plagioclase-poor tailings would be best for mineral carbonation. Although the mass of PGE tailings globally is inadequate to reduce global atmospheric carbon dioxide concentrations significantly, the carbonation of calcium- and magnesium-rich tailings can contribute to reducing the carbon footprint of individual mining operations.

\section{Mine Closure}

The procedures used to close PGE mines depends primarily on the method of mining and the character of the waste material. Reef-type deposits are typically developed using underground methods. Contact-type and conduit-type deposits can be developed by underground or open pit methods, depending upon the geometry of the orebody. For all these deposit types, open pit mining results in at least three different features after mining: the open pit, waste rock piles, and tailings storage facilities. Because of the scale of typical PGE mining activities, backfilling open pits is usually not practical. If the water table is above the bottom of the pit, the pit will fill with water and form a lake. The water quality of the lake will depend upon a number of factors, including the nature of the wall rock, the extent of interconnected underground mine workings that open to the pit, the water level in the pit, the local hydrology, and the climate, among others (Castendyk and Eary, 2009).

The long-term fate of tailing storage facilities depends upon the nature of the tailings and the method of construction of the facility. Some facilities can be regraded, capped, and revegetated. Others are designed to have a water cover in perpetuity to limit sulfide oxidation. Either type may have seepage that may require some form of water treatment.

The long-term fate of waste rock piles may include regrading, capping, and revegetation. Depending upon the acid-generating potential of the material, some piles may require some form of water treatment. An emerging issue for historical PGE tailings and piles is that older ore-processing techniques were not as efficient as those used today. As a consequence, historical tailings and waste piles can carry significant PGE grades. 


\section{Problems and Future Research}

The supply of PGE from primary and secondary sources currently meets society's demand for these metals. Even if demand increases (as it assuredly will), the in-ground identified mineral resources appear to be sufficient to supply the world's needs for several decades. The location of most of the in-ground resources in a few big deposits in a few places makes the primary production of PGE susceptible to supply disruption, however. The following section discusses this problem in more detail.

\section{Future Demand and Possible Risks to Supply}

The demand for PGEs continues to increase. PGE use in automobile catalytic converters is expected to increase as more-stringent automobile emission standards are adopted worldwide. An emerging industrial use for platinum is in fuel cells that provide electricity for automobiles, homes, and businesses. Fuel cells produce electricity through electrochemical reactions by combining oxygen with a hydrogen-bearing fuel over a catalyst, such as platinum, and produce only water and carbon dioxide as emissions.

Various studies have compared anticipated demand for the PGEs with the amount of PGE ore that has been positively identified by mineral exploration. Along with the anticipated supply of PGEs by recycling, the studies suggest that there are sufficient PGE resources in the ground to meet projected platinum demand well into the middle of the 21 st century (Tiax LLC, 2003; Wilburn and Bleiwas, 2004; Mudd, 2012; Wilburn, 2012). Mineral reserves in the Bushveld Complex would be sufficient to meet global platinum demand until 2040 (assuming an annual increase in platinum consumption of 2 percent). The much larger volume of mineralized rock that has been classified as mineral resources, coupled with the potential for additional undiscovered resources to be found, indicates that the potential amount of PGEs that could be mined will not be a constraint to PGE supply for many decades. Disruptions to the PGE supply are more likely to be affected by social, environmental, political, and economic factors rather than geologic issues or resource depletion (Mudd, 2012).

Variations in the annual average prices of the PGEs during the past 40 years illustrate the types of events and policies that could affect global supply and demand for mineral commodities (fig. N28). Some events, such as the oil embargo in the mid-1970s and the global recession that began in 2008, affected all metal prices (not just the prices of PGEs). Other effects can be specifically related to legislation passed by one or more Governments; for example, in the mid-1970s, catalytic converters, which use PGEs as the catalyst, were installed in automobiles to meet air standards set in the Clean Air Act Amendments of 1970 (84 Stat. 1705, P.L. 91-604; Gerard and Lave, 2005; McCarthy and others, 2011). Catalytic converters reduce harmful emissions from automobiles; the widespread adoption of catalytic converters, first in the United States in the 1970s, then in the European Union and Japan, increased demand for PGEs. Palladium supply was disrupted in 1999 and 2000 because Russian Government legislation temporarily blocked export of this metal (United Nations Conference on Trade and Development, undated). Other effects are related to problems with mineral production; for example, problems with a refinery in Rustenburg, South Africa, in 1989 caused a decrease in the world supply of rhodium. The PGE supply was also affected by work stoppages and miners' strikes in South Africa in 1986, 2011, and 2012 (Yager and others, 2012).

Production of PGEs requires power and water, both of which are in short supply in southern Africa. Africa depends on imports of oil and on production of synthetic fuels from coal to meet its fuel requirements (United Nations Conference on Trade and Development Secretariat, 1995). In January 2008, the South African mining industry briefly shut down almost all its operations because of the unpredictability of the power supply. Roughly one-quarter of the installed generating capacity was not available owing to system faults, planned maintenance, and a shortage of the coal used in power stations. The country was subject to short-notice blackouts, which made mining unsafe (Platinum Today, 2008). Expanding the mining capacity at the Bushveld Complex in South Africa is constrained by the power supply. Water is required to mine, process ore, and refine metals; if the water supply is restricted, then production is affected. In any country that is water-stressed, mining companies must strive to manage the supply and use of water to ensure continuation of operations (Anglo American Platinum Ltd., 2012).

The ultimate constraint on the development of PGE mineral resources may not be the presence of mineralized rock but rather the rock temperature. For example, the contact between the Main zone and the Lower Critical subzone in the Bushveld Complex can be traced to depths of $6 \mathrm{~km}$ in seismic surveys (Sargeant, 2001; Campbell, 2011), which indicates that mineralization associated with the Merensky Reef and the UG2 Chromitite may also be present at those depths (Cawthorn, 2010). These reefs are currently being mined at depths exceeding $2 \mathrm{~km}$ at the Northam Mine, where virgin rock temperatures of $70^{\circ} \mathrm{C}$ are measured at a depth of 2,176 m (Northam Platinum Ltd., 2008). Anglo American Platinum Ltd., whose operations include several mines in the Bushveld Complex, considers a virgin rock temperature of $75^{\circ} \mathrm{C}$ to be the limit of mining based on the anticipated technology, metal prices, and energy costs (Anglo American Platinum Ltd., 2011). By comparison, rock temperatures within the ore-bearing intrusions at the Talnakh area of Russia are up to $35^{\circ} \mathrm{C}$ in the Taimyrsky Mine, 27 to $30^{\circ} \mathrm{C}$ in the Skalisty Mine, and are anticipated to be 43 to $47^{\circ} \mathrm{C}$ in the area that will be developed by the Gluboky Mine (Kunilov, 1994). The massive sulfide ores in these Russian mines are highly reactive, however, and are prone to oxidation and spontaneous combustion. 


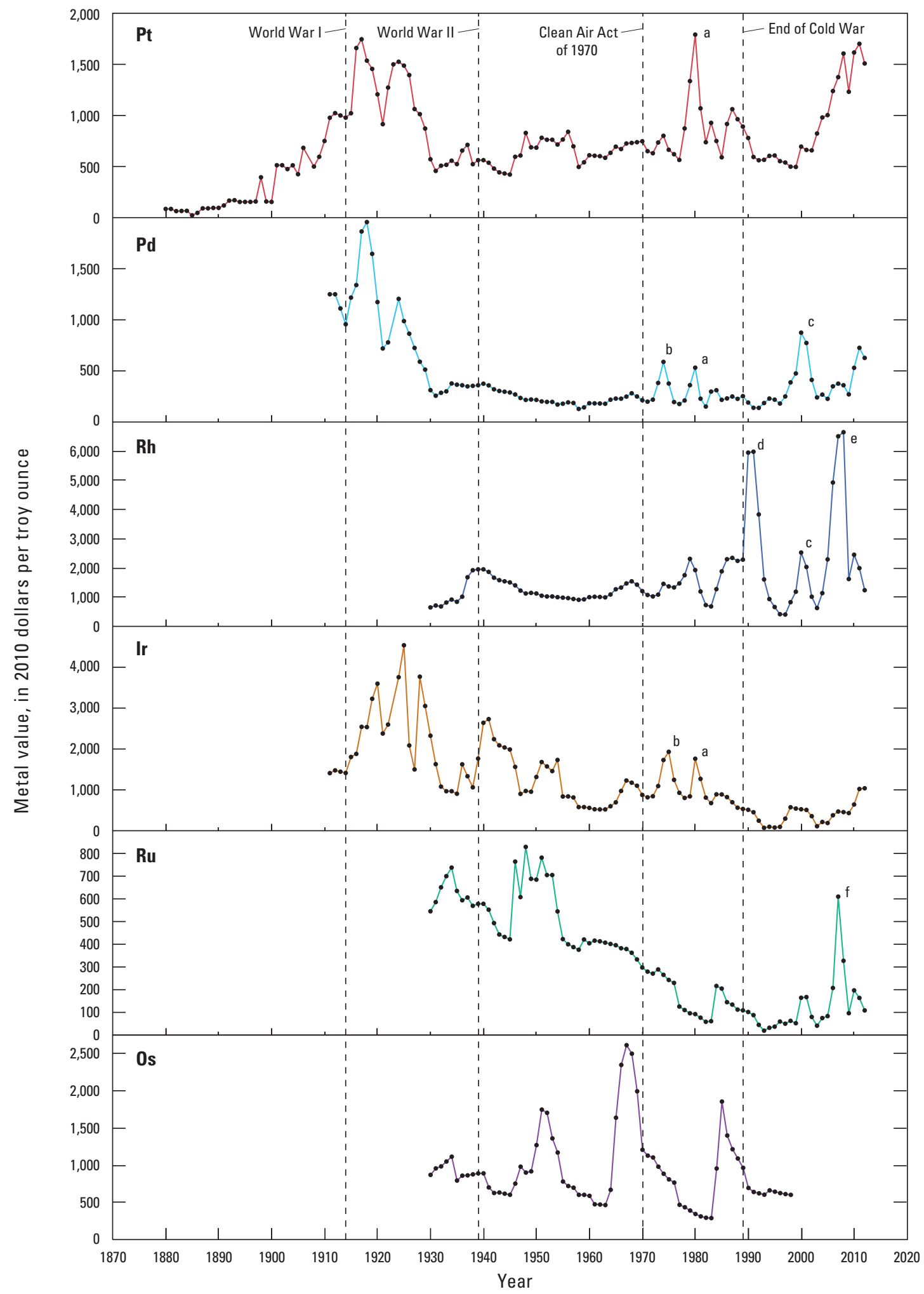

Figure N28. Graphs showing platinum-group-element prices (in constant U.S. dollars referenced to 2010) for platinum (Pt), palladium (Pd), rhodium (Rh), iridium (Ir), ruthenium (Ru), and osmium (Os) from 1880 to 2013. Major world events affecting pricing are shown as vertical dashed lines. Other major events shown are (a) investor speculation, (b) catalytic converter use begins and the Arab oil embargo, (c) shortfall of supplies of palladium from Russia, (d) disruption of supply because of problems at the Rustenburg refinery in South Africa, (e) increased demand for autocatalysts in Asian markets, and (f) increased ruthenium usage in electronics, especially in computer hard disk drives. National deflators are from the California Department of Finance (2012). Price data are from Plunkert and Jones (1999); Reese (1996); Hilliard (1998, 2000, 2004); Loferski (2012b, 2013c); and Platinum Today (2012). 


\section{Research Directions}

Successful exploration strategies for PGEs have been based on the magmatic deposit paradigm. This approach has proven highly successful and will likely result in additional discoveries. Its utility has a down side, however, in that other geologic settings in which PGEs may be concentrated have not been studied. Models strongly influence the observations made in both research and mineral exploration. For example, most economic geologists would not look for world-class PGE deposits in ophiolites. The most common magmatic ore type in ophiolites are chromitite deposits; all contain PGEs but are enriched in iridium relative to platinum (Mungall, 2002; Finnigan and others, 2008). There are a few examples of platinum-enriched chromitites in ophiolites, but these are too small to be of any economic consequence. Therefore, mineral exploration geologists have not searched for concentrations of magmatic sulfide minerals in ophiolites; however, a small magmatic sulfide deposit in the Acoje ophiolite, Philippines (Bacuta and others, 1990; Yumul, 2001), and occurrences in cumulates of the Shetland Ophiolite Complex, United Kingdom (Prichard and Lord, 1993), are examples that indicate that sulfide exsolution and PGE enrichment can take place in ophiolites. The examples of hydrothermal ore deposits with elevated PGEs are other reminders that an economic PGE deposit may be present in rocks that have not been explored.

Most researchers in the field of economic geology can supply a list of research topics that could be undertaken to alleviate concerns about the global availability of PGEs. One approach to addressing concerns is to find more deposits, but finding small deposits will not solve the problem. The deposits must be large (like one or more of the giants that currently dominate supply). Research to find new deposits can be basic, in which known deposits are mapped and characterized in order to understand how they form. The research can also be applied, in which the search for PGE deposits is extended into geologic settings where the deposits would be highly weathered, highly metamorphosed, or largely concealed. Additionally, research can focus on new ways to understand and integrate information so that new hypotheses can be proposed and tested. Research will be most effective if basic and applied research is integrated. It will also be more fruitful if expertise from many disciplines is involved in solving the problem.

\section{Acknowledgments}

Technical reviews by Art Bookstrom, Niki Wintzer, and Ennis Geraghty (Stillwater Mining Co.) greatly improved this chapter. Constructive comments were provided by Klaus Schulz and Dwight Bradley on an early version of the manuscript; John DeYoung and Suzanne Nicholson carefully looked through the document after the technical review was complete. Keith Labay helped create the world map, and Heather Parks constructed the first draft of the illustrations.

\section{References Cited}

Note: All Web links listed were active as of the access date but may no longer be available.

Abbott, D.M., Jr., Bullock, R.L., Gibbs, Betty, and Kunter, R.S., 2011, Technical report for the mining operations at Stillwater Mining Company, Stillwater Mine, $45^{\circ} 23^{\prime} \mathrm{N}$, $109^{\circ} 53^{\prime} \mathrm{W}$, East Boulder Mine, $45^{\circ} 30^{\prime} \mathrm{N}, 109^{\circ} 05^{\prime} \mathrm{W}$ : Denver, Colo., Behre Dolbear \& Company, Ltd. Project 11-030, 87 p., accessed June 25, 2013, at http://secfilings.nyse.com/ filing.php?ipage $=7682024$.

Adams, D.C., Miller, K.C., and Kargi, H., 1997, Reconciling physical properties with surface seismic data from a layered mafic intrusion: Tectonophysics, v. 271, nos. 1-2, p. 59-74.

African Rainbow Minerals Ltd., 2006, Nkomati-An open ended opportunity: African Rainbow Minerals Ltd. presentation, October 4, 2006, 47 slides, accessed April 23, 2012, at http:/www.arm.co.za/im/files/ presentations/2006/nkomati_expansion04oct06.pdf.

African Rainbow Minerals Ltd., 2010, Mineral resources and reserves 2010: African Rainbow Minerals Ltd., 31 p., accessed September 12, 2011, at http:/www.arm.co.za/im/ files/annual/2010/f/ARM_resources_reserves_2010.pdf.

African Rainbow Minerals Ltd., 2011, Mineral resources and reserves 2011: African Rainbow Minerals Ltd., 31 p., accessed January 26, 2011, at http://www.arm.co.za/im/files/ annual/2011/download/ARM-resources-and-reserves-2011.pdf.

Alapieti, T.T., and Lahtinen, J.J., 2002, Platinum-group element mineralization in layered intrusions of northern Finland and the Kola Peninsula, Russia, in Cabri, L.J., ed., The geology, geochemistry, mineralogy and mineral beneficiation of platinum-group elements: Montreal, Quebec, Canada, Canadian Institute of Mining, Metallurgy and Petroleum Special Volume 54, p. 507-546.

Allaart, J.H., comp., 1998, Geological map of Greenland map sheet no. 2, Frederikshåb Isblink-Søndre Strømfjord, in Geological Survey of Denmark and Greenland, Geological map of Greenland, 1:500,000, Frederikshåb Isblink-Søndre Strømfjord (sheet 2): Geological Survey of Denmark and Greenland, Geology of Denmark and Greenland Map Series CD 6, CD-ROM.

Alvarez, Juan, Khosrowshahi, Sia, Gonzalez, J.P., and Gatley, Stephen, 2009, Technical report on the Aguablanca Ni-Cu deposit, Extremadura region, Spain, NI 43-101 technical report, prepared for Rio Narcea Recursos S.A. (part of Lundin Mining Corp.) [Filing date March 31, 2009]: Golder Associates Global Ibérica, S.L., Report no. 08511150292, March 31, 110 p. plus 7 appendixes. [Also available at http://www.sedar.com.] 
American Physical Society Panel on Public Affairs and the Materials Research Society, 2011, Energy critical elementsSecuring materials for emerging technologies: Washington, D.C., American Physical Society, 19 p. plus 2 appendixes, accessed February 1, 2013, at http://www.aps.org/policy/ reports/popa-reports/upload/elementsreport.pdf.

Anderson, W.B., and Martineau, M.P., 2002, New discoveries of platinum and palladium in the central Urals of Russia: London, United Kingdom, Eurasia Mining plc, 4 p., accessed April 19, 2013, at http://www.nicholas.duke.edu/ people/faculty/boudreau/9thPtSymposium/Anderson Abstract.pdf.

Angeli, Nelson, 2005, Platinum group minerals in eastern Brazil: Platinum Metals Review, v. 49, no. 1, p 41-53.

Anglo American Platinum Ltd., 2009, Platinum estimates as of 31 December 2009: Anglo American Platinum Ltd. Web page, accessed September 23, 2011, at http://ar09.angloamerican.solutions.investis.com/ ore_reserves/platinum/projects.html.

Anglo American Platinum Ltd., 2011, Integrated annual report 2011: Anglo American Platinum Ltd., 322 p., accessed October 6, 2016, at http://www.angloamericanplatinum.com/ $\sim$ media/Files/A/Anglo-American-Platinum/AA\%20 Plat $\% 20-\%$ 20INTEGRATED\%20ANNUAL $\% 20$ REPORT\%202011.pdf.

Anglo American Platinum Ltd., 2012, Water, section of Hardwiring sustainability with the future in mindSustainable development report 2012: Anglo American Platinum Ltd., p. 108-115, accessed February 1, 2016, at http://www.angloamericanplatinum.com/ /media/ Files/A/Anglo-American-Platinum/annual-reports/ aapsdreport2012-150313.pdf.

Anikina, E.V., Malitch, K.N., Pushkarev, E.V., and Shmelev, V.R., 2014, The Nizhny Tagil and Volkovsky Massifs of the Uralian platinum belt, and related deposits-Field trip guidebook for International Platinum Symposium, 12th, Yekaterinburg, Russia, August 15-16, 2014: St. Petersburg, Russia, Russian Academy of Sciences, Zavaritsky Institute of Geology and Geochemistry (IGG UB RAS), 48 p., accessed September 18, 2015, at http://www.igg.uran.ru/ sites/default/files/12IPS/3b_12_ips_guidebook_nizhny_ tagil-volkovsky_deposits.pdf.

Appel, P.W.U., Dahl, Ole, Kalvig, Per, and Polat, Ali, 2011, Discovery of new PGE mineralization in the Precambrian Fiskenaesset anorthosite complex, West Greenland: Danmarks og Grønlands Geologiske Undersøgelse Rapport 2011/3, 48 p. and CD-ROM.

Aquarius Platinum Ltd., 2011, Aquarius - A platinum investmentAnnual report 2011: Aquarius Platinum Ltd., 127 p., accessed September 13, 2012, at http://aquariusplatinum.com/ sites/aquariusplatinum.com/files/ckfinder/files/2011_AQP Annual_Report_v2.pdf.
Armitage, Mike, 2007, Kun-Manie nickel project valuation, prepared for Amur Minerals Corp: Vancouver, British Columbia, Canada, SRK Consulting, February 5, 4 p.

Armitage, P., McDonald, I., and Tredoux, M., 2007, A geological investigation of the Waterberg hydrothermal platinum deposit, Mookgophong, Limpopo Province, South Africa: TransactionsInstitution of Mining and Metallurgy, Section B-Applied Earth Science, v. 116, no. 3, p. 113-129. [Also available at http://dx.doi.org/10.1179/174327507X207483.]

Armstrong, R., and Wilson, A.H., 2000, A SHRIMP U-Pb study of zircons from the layered sequence of the Great Dyke, Zimbabwe, and a granitoid anatectic dyke: Earth and Planetary Science Letters, v. 180, nos. 1-2, July 30, p. 1-12. [Also available at http://dx.doi.org/10.1016/ S0012-821X(00)00162-X.]

Arndt, N.T., 2005, The conduits of magmatic ore deposits, in Mungall, J.E., ed., Exploration for platinum-group element deposits: Mineralogical Association of Canada Short Course Series, v. 35, p. 181-201.

Augé, Thierry, and Legendre, Olivier, 1994, Platinum-group element oxides from the Pirogues ophiolitic mineralization, New Caledonia-Origin and significance: Economic Geology, v. 89, p. 1454-1468. [Also available at http://dx.doi.org/10.2113/gsecongeo.89.7.1454.]

Azaroual, M., Romand, B., Freyssinet, P., and Disnar, J.-R., 2001 , Solubility of platinum in aqueous solutions at $25^{\circ} \mathrm{C}$ and $\mathrm{pHs} 4$ to 10 under oxidizing conditions: Geochimica et Cosmochimica Acta, v. 65, no. 24, p. 4453-4466. [Also available at http://dx.doi.org/10.1016/S00167037(01)00752-9.]

Bacuta, G.C., Jr., Kay, R.W., Gibbs, A.K., and Lipin, B.R., 1990, Platinum-group element abundance and distribution in chromite deposits of the Acoje Block, Zambales ophiolite complex, Philippines: Journal of Geochemical Exploration, v. 37, no. 1, p. 113-145. [Also available at http://dx.doi.org/ 10.1016/0375-6742(90)90086-P.]

Bailey, Joshua, 2012, Technical report on the Parkin Offset properties, Sudbury, Ontario-NI 43-101 technical report [Filing date March 29, 2012; effective date December 31, 2011]: Wallbridge Mining Company Ltd., 83 p., accessed September 9, 2015, at http://www.sedar.com.)

Bailly, L., Augé, T., Cocherie, A., Trofimov, N.N., Golubev, A.I., Tkachev, A.V., and Cherkasov, S.V., 2009, New data on the age of the Burakovsky layered intrusion, Karelia: Doklady Earth Sciences, v. 426, no. 1, p. 534-538. [Also available at http://dx.doi.org/10.1134/S1028334X09040059.]

Baker, C.L., Kelly, R.I., Parker, J.R., Ayer, J.A., and Easton, R.M., eds., 2003, Summary of field work and other activities 2003, with a section on Regional geology of the Lac des Iles area, by Stone, D., Lavigne, M.J., Schnieders, B., Scott, J., and Wagner, D.: Ontario Geological Survey Open File Report 6120, p. 15-1 to 15-25. 
Balch, S.J., 2005, The geophysical signatures of PGE deposits, in Mungall, J.E., ed., Exploration for platinum-group element deposits: Mineralogical Association of Canada Short Course Series, v. 35, p. 275-285.

Ball, S.H., and Shaler, M.K., 1914, Economic geology of the Belgian Congo, Central Africa: Economic Geology, v. 9, p. 605-663.

Banakar, V.K., Hein, J.R., Rajani, R.P., and Chodankar, A.R., 2007, Platinum group elements and gold in ferromanganese crusts from Afanasiy-Nikitin seamount, equatorial Indian Ocean-Sources and fractionation: Journal of Earth Systems Science, v. 116, no. 1, p. 3-13. [Also available at http://dx.doi.org/10.1007/s12040-007-0002-x.]

Barker, J.C., 1986, Platinum-group metals, gold and chromium resource potential offshore of Platinum, Alaska, in 17th Annual Underwater Mining Conference, Biloxi, Miss., November 2-5, 14 p.

Barker, J.C., and Lamal, Kathryn, 1989, Offshore extension of platiniferous bedrock and associated sedimentation of the Goodnews Bay ultramafic complex, Alaska: Marine Mining, v. 8 , no. 4 , p. 365-390.

Barker, J.C., Lamal, Kathryn, Mardock, C.L., and Hirt, W.C., 1988, Placer platinum-group metals offshore of the Goodnews Bay Ultramafic Complex, southwest Alaska: U.S. Bureau of Mines Open-File Report 53-88, 60 p.

Barnes, S.-J., and Liu, Weihua, 2012, Pt and Pd mobility in hydrothermal fluids - Evidence from komatiites and from thermodynamic modelling: Ore Geology Reviews, v. 44, p. 49-58. [Also available at http://dx.doi.org/10.1016/ j.oregeorev.2011.08.004.]

Barnes, S.-J., and Maier, W.D., 1999, The fractionation of $\mathrm{Ni}, \mathrm{Cu}$ and the noble metals in silicate and sulphide liquids, in Keays, R.R., Lesher, C.M., Lightfoot, P.C., and Farrow, C.E.G., eds., Dynamic processes in magmatic ore deposits and their application in mineral exploration: Geological Association of Canada Short Course Notes, v. 13, p. 69-106.

Barnes, S-J., and Maier, W.D., 2002, Platinum-group element distributions in the Rustenburg Layered Suite of the Bushveld Complex, South Africa, in Cabri, L.J., ed., The geology, geochemistry, mineralogy and mineral beneficiation of platinum-group elements: Montreal, Quebec, Canada, Canadian Institute of Mining, Metallurgy and Petroleum Special Volume 54, p. 431-458.

Barnes, S.-J., McIntyre, J.R., Nisbet, B.W., and Williams, C.R., 1990, Platinum group element mineralisation in the Munni Munni Complex, Western Australia: Mineralogy and Petrology, v. 42, nos. 1-4, p. 141-164.
Barnes, S.-J., Prichard, H.M., Cox, R.A., Fisher, P.C., and Godel, Belinda, 2008, The location of the chalcophile and siderophile elements in platinum-group ore deposits (a textural, microbeam and whole rock geochemical study) - Implications for the formation of deposits: Chemical Geology, v. 248, nos. 3-4, p. 295-317. [Also available at http://dx.doi.org/10.1016/j.chemgeo.2007.08.004.]

Barrick Gold Corp., 2008, Annual information form for the year ended December 31, 2007 [Filing date March 28, 2008]: Toronto, Ontario, Canada, Barrick Gold Corp., accessed September 9, 2015, at http://www.sedar.com/.

Barrie, C.T., MacTavish, A.D., Walford, P.C., Chataway, R., and Middaugh, R., 2002, Contact-type and magnetitite reef-type $\mathrm{Pd}-\mathrm{Cu}$ mineralization in ferroan olivine gabbros of the Coldwell Complex, Ontario, in Cabri, L.J., ed., The geology, geochemistry, mineralogy and mineral beneficiation of platinum-group elements: Montreal, Quebec, Canada, Canadian Institute of Mining, Metallurgy and Petroleum Special Volume 54, p. 321-337.

Barrueto, H.R., and Hunt, W., 2010, Main features of the Pt-Pd chromitite-type ore deposit, Tróia unit, Cruzeta complex, northeast Brazil-Insights provided by microscopic and chemical approaches, in Brown, G.H., Jugo, P.J., Lesher, C.M., and Mungall, J.E., eds., Abstracts, 11 th International Platinum Symposium, 21-24 June 2010, Sudbury, Ontario, Canada: Sudbury, Ontario, Canada, Ontario Geological Survey, Miscellaneous Release-Data 269, 4 p.

Bauba Platinum, 2012, Exploration update, May 2012: Bauba Platinum Presentation, 22 slides, accessed September 3, 2012, at http://www.baubaplatinum.co.za/ ir/f/Bauba-presentation-May2012.pdf.

Baxter, K., Dreisinger, D., Ferron, J., Fleming, C.D., Hunter, D., and Murray, W., 2005, The application of the PLATSOL ${ }^{\text {TM }}$ process to copper-nickel-cobalt-PGE/PGM concentrates from Polymet Mining's NorthMet deposit: ALTA 2005 World Forum on Nickel and Cobalt Hydrometallurgy, Perth, Western Australia, Australia, May 16-18, 2005, presentation, accessed AOctober 6, 2016, at https:/www.researchgate.net/ publicatio/267920431_THE_APPLICATION_OF_THE PLATSOL_PROCESS_TO_COPPER-_NICKEL-COBALTPGEPGM_CONCENTRATES_FROM_POLYMET_ MINING'S_NORTHMET_DEPOSIT.

Bellona Foundation, 2010, Environmental challenges in the Arctic, Norilsk Nickel-The Soviet legacy of industrial pollution: Oslo, Norway, Bellona Foundation, 69 p., accessed October 6, 2016, at http://bellona.org/assets/ sites/4/Norilsk-Nickel-The-Soviet-Legacy-of-IndustrialPollution.pdf. 
Berg, H.C., Jones, D.L., and Richter, D.H., 1972, GravinaNutzotin belt-Tectonic significance of an upper Mesozoic sedimentary and volcanic sequence in southern and southeastern Alaska, in Geological Survey Research 1972: U.S. Geological Survey Professional Paper 800-D, p. D1-D24.

Berg, H.C., Jones, D.L., and Coney, P.J., 1978, Map showing pre-Cenozoic tectonostratigraphic terranes of southeastern Alaska and adjacent areas: U.S. Geological Survey OpenFile Report 78-1085, 2 sheets, scale 1:1,000,000.

Berger, V.I., Singer, D.A., Bliss, J.D., and Moring, B.C., 2011, Ni-Co laterite deposits of the world-Database and grade and tonnage models: U.S. Geological Survey Open-File Report 2011-1058, accessed May 6, 2013, at http://pubs.usgs.gov/of/2011/1058/.

Blackthorn Resources Ltd., 2009, Annual report 2009: Sydney, New South Wales, Australia, Blackthorn Resources Ltd., 58 p.

Bolton, F., 2013, Proposed establishment of a platinum mining operation and related surface infrastructure-Magazynskraal Platinum Mine: SLR Global Environmental Solutions Project No. B001-03, Environmental Impact Assessment and Environmental Management Programme Report for Richtrau No. 123 (Pty) Limited: Johannesburg, South Africa, SLR Consulting (Africa) (Pty) Ltd., March, 339 p., accessed October 6, 2016, at http://www.sahra.org.za/ sahris/sites/default/files/additionaldocs/MGZ_EIAEMP_ Public_22\%20March\%202013.pdf.

Borg, G., Tredoux, M., Maiden, K.J., Sellschop, J.P.F., and Wayward, O.F.D., 1987, PGE- and Au- distribution in riftrelated volcanics, sediments and stratabound $\mathrm{Cu} / \mathrm{Ag}$ ores of Middle Proterozoic age in central SWA/Namibia, in Prichard, H.M., Potts, P.J., Bowles, J.F.W., and Cribb, S.J., eds., Geo-Platinum 87 [Proceedings of the Geo-Platinum 87 symposium held at the Open University, Milton Keynes, United Kingdom, on April 22-23]: New York, N.Y., Elsevier, p. 303-317.

British Geological Survey, 2012, Risk list 2012-An update to the supply risk index for elements or element groups that are of economic value: Keyworth, Nottingham, United Kingdom, British Geological Survey, 12 p., accessed February 1, 2013, at http://www.bgs.ac.uk/ downloads/start.cfm?id=2643.

Brozdowski, R.A., 1985, Cumulate xenoliths in the Lodgepole, Enos Mountain and Susie Peak intrusions-A guide, in Czamanske, G.K., and Zientek, M.L., eds., The Stillwater Complex, Montana-Geology and guide: Butte, Mont., Montana Bureau of Mines and Geology Special Publication v. 92, p. $368-372$.
Bruland, K.W., and Lohan, M.C., 2003, Controls of trace metals in seawater, in Elderfield, Henry, ed., The oceans and marine geochemistry, v. 6 of Holland, H.D., and Turekian, K.K., eds., Treatise on geochemistry: Oxford, United Kingdom, Elsevier-Pergamon, p. 23-47. [Also available at http://www.sciencedirect.com/science/article/ pii/B0080437516061053.]

Bryan, S.E., and Ernst, R.E., 2008, Revised definition of large igneous provinces (LIPs): Earth-Science Reviews, v. 86, nos. 1-4, p. 175-202. [Also available at http://dx.doi.org/10.1016/j.earscirev.2007.08.008.]

Buchanan, P.C., Koeberl, Christian, and Reimold, W.U., 1999, Petrogenesis of the Dullstroom Formation, Bushveld magmatic province, South Africa: Contributions to Mineralogy and Petrology, v. 137, nos. 1-2, p. 133-146. [Also available at http://dx.doi.org/10.1007/s004100050587.]

Buchert, Matthias, Schüler, Doris, and Bleher, Daniel, 2009, Critical metals for future sustainable technologies and their recycling potential: United Nations Environment Programme \& United Nations University, 81 p., accessed February 1, 2013, at http://www.unep.fr/shared/publications/ pdf/DTIx1202xPA-Critical Metals and their Recycling Potential.pdf.

Burg, J.-P., Bodinier, J.-L., Gerya, T., Bedini, R.-M., Boudier, F., Dautria, J.-M., Prikhodko, V., Efimov, A., Pupier, E., and Balanec, J.-L., 2009, Translithospheric mantle diapirismGeological evidence and numerical modeling of the Kondyor Zoned Ultramafic Complex (Russian Far-East): Journal of Petrology, v. 50, no. 2, p. 289-321. [Also available at http://dx.doi.org/10.1093/petrology/egn083.]

Burgess, Harry, Gowans, Richard, Jacobs, Christopher, Murahwi, Charley, and Damjanović, Bogdan, 2012, NI 43-101 technical report-Feasibility study-McFaulds Lake property, Eagle's Nest project, James Bay Lowlands, Ontario, Canada, prepared for Noront Resources Ltd. [Effective date September 4, 2012]: Toronto, Ontario, Canada, Micon International Ltd., October 19, 197 p. [Also available at http://www.sedar.com.]

Butler, Jonathan, 2012, Platinum 2012: Royston, United Kingdom, Johnson Matthey Plc, 60 p.

Buttgenbach, H., 1908, Les gisements miniers du Katanga [Mineral deposits in Katanga], in Studt, F.E., Cornet, J., and Buttgenbach, H., Carte géologique du Katanga et notes descriptives [Geologic map of Katanga and descriptive notes]: Brussels, Belgium, Musée Royal de l'Afrique Central, Annales, Géophysique, Minéralogie, and Paléontologie, Série II, Katanga. I, p. 17-93. [In French.] 
Buys, Stephan, Rule, Chris, and Curry, Dan, 2013, The application of large scale stirred milling to the retreatment of Merensky platinum tailings, 14 p., in Canadian Mineral Processors Annual Operators Conference, 37th, Ottawa, Ontario, Canada, January 18-20, 2005, Proceedings (2004-2008): Ottawa, Ontario, Canada, Canadian Mineral Processors Society, CD-ROM. [Also available at http://www.isamill.com/EN/downloads/Pages/papers.aspx.]

Cabral, A.R., Lehmann, B., Kwitko, R., and Cravo Costa, C.H., 2002, The Serra Pelada Au-Pd-Pt deposit, Carajás mineral province, northern Brazil-Reconnaissance mineralogy and chemistry of very high grade palladian gold mineralization: Economic Geology, v. 97, p. 1127-1138. [Also available at http://dx.doi.org/10.2113/gsecongeo.97.5.1127.]

Cabri, L.J., 1992, The distribution of trace precious metals in minerals and mineral products: Mineralogical Magazine, v. 56, no. 384, p. 298-308. [Also available at http://dx.doi.org/ 10.1180/minmag.1992.056.384.01.]

Cabri, L.J., 2002, The platinum-group minerals, in Cabri, L.J., ed., The geology, geochemistry, mineralogy and mineral beneficiation of platinum-group elements: Montreal, Quebec, Canada, Canadian Institute of Mining, Metallurgy and Petroleum Special Volume 54, p. 13-130.

Cabri, L.J., Sylvester, P.J., Tubrett, M.N., Peregoedova, Ania, and Laflamme, J.H.G., 2003, Comparison of LAM-ICPMS and Micro-Pixe results for palladium and rhodium in selected samples of Noril'sk and Talnakh sulfides: Canadian Mineralogist, v. 41, no. 2, p. 321-329. [Also available at http://dx.doi.org/10.2113/gscanmin.41.2.321.]

California Department of Finance, 2012, National deflatorsCalendar and fiscal year-From 1950: California Department of Finance Web page, accessed December 4, 2012, at http://www.dof.ca.gov/html/fs_data/latestecondata/ FS_Price.htm.

Cameron, D.E., and Garmoe, W.J., 1987, Geology of skarn and high-grade gold in the Carr Fork Mine, Utah: Economic Geology, v. 82, p. 1319-1333. [Also available at http://dx.doi.org/10.2113/gsecongeo.82.5.1319.]

Cameron, E.M., and Hattori, K.H., 2005, Platinum-group elementsin geochemical exploration, in Mungall, J.E., ed., Exploration for platinum-group element deposits: Mineralogical Association of Canada Short Course Series, v. 35, p. 287-307.

Campbell, Geoff, 2006, High resolution aeromagnetic mapping of "loss-of-ground" features at platinum and coal mines in South Africa: South African Journal of Geology, v. 109, no. 4, p. 439-458. [Also available at http://dx.doi.org/10.2113/ gssajg.109.4.439.]
Campbell, Geoff, 2011, Exploration geophysics of the Bushveld Complex in South Africa: The Leading Edge, v. 30, no. 6, June 2011, p. 622-638. [Also available at http://dx.doi.org/10.1190/1.3599148.]

Campbell, I.H., and Naldrett, A.J., 1979, The influence of silicate-sulfide ratios on the geochemistry of magmatic sulfides: Economic Geology, v. 74, p. 1503-1505.

Carroll, Sandy, 2005, The viability of the Kalplats platinum group element deposit: Pretoria, South Africa, University of Pretoria, M.Sc. thesis, 105 p. [Also available at http://hdl.handle.net/2263/26174.]

Carter, Andrew, Corpuz, Pacifico, Bridson, Philip, and McCracken, Todd, 2012, Wellgreen Project preliminary economic assessment, Yukon, Canada, NI-43-101 technical report prepared for Prophecy Platinum: Vancouver, British Columbia, Canada, Tetra Tech-Waldrop, variously paged, accessed June 9, 2016, at http://www.sedar.com/ GetFile.do?lang $=\mathrm{EN} \&$ docClass $=24 \&$ issuerNo $=00024464 \&$ issuerType $=03 \&$ projectNo $=01924122 \&$ docId $=3168099$

Carville, D.P., Leckie, J.F., Moorhead, C.F., Rayner, J.G., and Durbin, A.A., 1990, Coronation Hill gold-platinum-palladium deposit, in Hughes, F.E., ed., Geology of the mineral deposits of Australia and Papua New Guinea: Melbourne, Victoria, Australia, Australasian Institute of Mining and Metallurgy Monograph, 2 vols., no. 14, p. 759-762.

Castendyk, D.N., and Eary, L.E., eds., 2009, Mine pit lakesCharacteristics, predictive modeling, and sustainability: Littleton, Colo., Society for Mining, Metallurgy, and Exploration, Management Technologies for Metal Mining Influenced Water Series, v. 3, 304 p.

Cawthorn, R.G., 1999, The discovery of the platiniferous Merensky Reef in 1924: South African Journal of Geology, v. 102, no. 3, p. 178-183.

Cawthorn, R.G., 2010, The platinum-group element deposits of the Bushveld Complex in South Africa: Platinum Metals Review, v. 54, no. 4, p. 205-215. [Also available at http://dx.doi.org/10.1595/147106710X520222.]

Cawthorn, R.G., Merkle, R.K.W., and Viljoen, M.J., 2002, Platinum-group element deposits in the Bushveld Complex, South Africa, in Cabri, L.J., ed., The geology, geochemistry, mineralogy and mineral beneficiation of platinum-group elements: Montreal, Quebec, Canada, Canadian Institute of Mining, Metallurgy, and Petroleum Special Volume 54, p. 389-429. 
Central African Mining \& Exploration Company Plc, 2009, Compliant mineral resource estimate for the Bokai platinum prospect: Central African Mining \& Exploration Company plc press release, July 13, 2009, accessed October 6, 2016, at http://www.georesources.net/index.php/component/ content/article/38-news/248-camec-compliant-mineralresource-estimate-for-bokai-platinum-prospect.

Chatterjee, Snehamoy, and Bandopadhyay, Sukumar, 2011, Goodnews Bay platinum resource estimation using least squares support vector regression with selection of input space dimension and hyperparameters: Natural Resources Research, v. 20, no. 2, p. 117-129. [Also available at http://dx.doi.org/10.1007/s11053-011-9140-6.]

Chen, Cynthia, Sedwick, P.N., and Sharma, Mukul, 2009, Anthropogenic osmium in rain and snow reveals globalscale atmospheric contamination: Proceedings of the National Academy of Sciences of the United States of America, v. 106, no. 19, p. 7724-7728. [Also available at http://dx.doi.org/10.1073/pnas.0811803106.]

Chunnett, G.K., and Rompel, A.K.K., 2004, Data integration for structural interpretation in the Bushveld Complex, in International Platinum Conference "Platinum Adding Value," Sun City, South Africa, October 3-7, 2004, Proceedings: Johannesburg, South Africa, South African Institute of Mining and Metallurgy, p. 265-268.

Clay, Andy, Motloung, Mpai, Patel, Khalid, and Tayelor, Richard, 2010, Independent technical statement for the Volspruit project as at 2nd December 2010, in Venmyn Rand (Pty) Ltd., Independent technical experts report on the mineral assets of Sylvania Resources Limited in the form of a competent persons report by Venmyn Rand (Pty) Limited, prepared for Sylvania Resources Ltd.: Johannesburg, South Africa, Venmyn Rand (Pty) Ltd., p. 138-144, accessed March 6, 2012, at http://www.sylvaniaplatinum.com/b/files/ cpr-sylvania-resources.pdf.

Coffin, M.F., and Eldholm, Olav, 1994, Large igneous provinces - Crustal structure, dimensions, and external consequences: Reviews in Geophysics, v. 32, no. 1, p. 1-36. [Also available at http://dx.doi.org/10.1029/93RG02508.]

Coker, W.B., Dunn, C.E., Hall, G.E.M., Rencz, A.N., DiLabio, R.N.W., Spirito, W.A., and Campbell, J.E., 1991, The behavior of platinum group elements in the surficial environment at Ferguson Lake, N.W.T., Rottenstone Lake, Sask. and Sudbury, Ont., Canada: Journal of Geochemical Exploration, v. 40, nos. 1-3, p. 165-192. [Also available at http://dx.doi.org/10.1016/0375-6742(91)90037-U.]

Cole, Glen, and El-Rassi, Dorota, 2009, Mineral resource evaluation-Thunder Bay North polymetallic project, Ontario, Canada, prepared for Magma Metals (Canada) Ltd.: Toronto, Ontario, Canada, SRK Consulting, SRK Project No. 3CM017.000, September 29, 134 p.
Colombo, C., Oates, C.J., Monhemius, A.J., and Plant, J.A., 2008, Complexation of platinum, palladium and rhodium with inorganic ligands in the environment: GeochemistryExploration, Environment, Analysis, v. 8, p. 91-101. [Also available at http://dx.doi.org/10.1144/1467-7873/07-151.]

Conn, H.K., 1979, The Johns-Manville platinum-palladium prospect, Stillwater Complex, Montana, U.S.A.: Canadian Mineralogist, v. 17, p. 463-468.

Corfu, F., and Lightfoot, P.C., 1996, U-Pb geochronology of the sublayer environment, Sudbury igneous complex, Ontario: Economic Geology, v. 91, p. 1263-1269. [Also available at http://dx.doi.org/10.2113/gsecongeo.91.7.1263.]

Council on Ethics, 2009, To the Ministry of FinanceRecommendation of 16 February 2009: Oslo, Norway, Council on Ethics for the Government Pension Fund-Global, 21 p., accessed June 26, 2013, at https://www.regjeringen.no/globalassets/upload/fin/ statens-pensjonsfond/recommendation_norilsk.pdf.

Czamanske, G.K., Haffty, Joseph, and Nabbs, S.W., 1981, $\mathrm{Pt}, \mathrm{Pd}$, and $\mathrm{Rh}$ analyses and beneficiation of mineralized mafic rocks from the La Perouse Layered Gabbro, Alaska: Economic Geology, v. 76, p. 2001-2011. [Also available at http://dx.doi.org/10.2113/gsecongeo.76.7.2001.]

Dalvi, A.D., Bacon, W.G., and Osborn, R.C., 2004, The past and the future of nickel laterites: Prospectors and Developers Association of Canada (PDAC) 2004 International Convention, Trade Show \& Investors Exchange, Toronto, Ontario, Canada, March 7-10, 2004, presentation, 27 p., accessed April 1, 2010, at http://www.pdac.ca/pdac/ publications/papers/2004/techprgm-dalvi-bacon.pdf.

Davison, G.E., and Chunnett, G.K., 1999, Seismic exploration for Merensky Reef-The way ahead: South African Journal of Geology, v. 102, no. 3, p. 261-267.

Decker, John, Bergman, S.C., Blodgett, R.B., Box, S.E., Bundtzen, T.K., Clough, J.G., Coonrad, W.L., Gilbert, W.G., Miller, M.L., Murphy, J.M., Robinson, M.S., and Wallace, W.K., 1994, Geology of southwestern Alaska, in Plafker, George, and Berg, H.C., eds., The geology of Alaska: Boulder, Colo., Geological Society of America, p. 285-310. [Also available at http://dggs.alaska.gov/pubs/id/22261.]

Deer, W.A., Howie, R.A., and Zussman, J., 1966, An introduction to rock forming minerals: London, United Kingdom, Longman Group Ltd., 528 p.

DeMille, J.B., 1947, Strategic minerals-A summary of uses, world output, stockpiles, procurement: New York, N.Y., McGraw-Hill, 626 p. 
Desautels, Pierre, and Zurowski, Gordon, 2012, Updated NI 43-101 technical report on the NorthMet depositMinnesota, USA, prepared for PolyMet Mining Corp. [Filing date October 31, 2012]: Barrie, Ontario, Canada, AGP Mining Consultants Inc., October 12, 238 p. plus 7 appendixes. [Also available at http://www.sedar.com.]

de Vos, E., Edwards, S.J., McDonald, I., Wray, D.S., and Carey, P.J., 2002, A baseline survey of the distribution and origin of platinum group elements in contemporary fluvial sediments of the Kentish Stour, England: Applied Geochemistry, v. 17, no. 8, p. 1115-1121. [Also available at http://dx.doi.org/10.1016/S0883-2927(02)00010-0.]

Diakov, Sergei, West, Richard, Schissel, Don, Krivtsov, Anatoly, Kochnev-Pervoukhov, Vladimir, and Migachev, Igor, 2002, Recent advances in the Noril'sk model and its application for exploration of Ni-Cu-PGE sulfide deposits, in Goldfarb, R.J., and Nielsen, R.L., eds., Integrated methods for discovery - Global exploration in the 21st century: Littleton, Colo., Society of Economic Geologists Special Publication 9, p. 203-226.

Discovery Metals Ltd., 2013, Dikoloti nickel project: Discovery Metals Ltd. Web page, accessed March 18, 2012, at http://web.archive.org/web/20121214171224/http:// www.discoverymetals.com/dikoloti-nickel-project.

Doran, Rod, Churchill, B.C., Cox, J.J., and McBride, Tim, 2012, Pre-feasibility report on the Broken Hammer Project, Sudbury, Ontario, Canada, NI 43-101 technical report, prepared for Wallbridge Mining Company Ltd. [Filing date November 27, 2012]: GENIVAR, Inc., Reference 1870/121-16220-00, October 8, 191 p. [Also available at http://www.sedar.com.]

Drennan, Martin, and Fell, Michael, 2010, Technical report and resource estimate-2010 update for the Geordie Lake property, northern Ontario, prepared for Marathon PGM Corp. [Filing date June 14, 2010]: Hamilton, Ontario, Canada, Python Mining Consultants Inc., June 4, 63 p. plus 6 appendixes. [Also available at http://www.sedar.com.]

Duluth Metals Ltd., 2011, Duluth Metals commences drilling program on platinum targets in the Land O'Dixie property: Duluth Metals news release, August 2, accessed November 21, 2016, at http://www.prnewswire.com/ news-releases/duluth-metals-commences-drilling-program-onplatinum-targets-on-the-land-odixie-property-126568668.html.

Dunn, C.E., 1986, Biogeochemistry as an aid to exploration for gold, platinum and palladium in the northern forests of Saskatchewan, Canada: Journal of Geochemical Exploration, v. 25, nos. 1-2, p. 21-40. [Also available at http://dx.doi.org/10.1016/0375-6742(86)90005-1.]
Duparc, L., and Tikonowitch, M.N., 1920, Le platine et les gîtes platinifères de l'Oural et du monde [Platinum and platinum deposits of the Urals and the world]: Geneva, Switzerland, Sonor, 524 p. [In French.]

Ek, K.H., Morrison, G.M., and Rauch, Sebastien, 2004, Environmental routes for platinum group elements to biological materials-A review: Science of the Total Environment, v. 334-335, p. 21-38. [Also available at http://dx.doi.org/ 10.1016/j.scitotenv.2004.04.027.]

Ernst, R.E., and Buchan, K.L., 2001, Large mafic magmatic events through time and links to mantle plume heads, in Ernst, R.E., and Buchan, K.L., eds., Mantle plumes-Their identification through time: Boulder, Colo., Geological Society of America Special Paper v. 352, p. 483-575.

Eurasia Mining plc, 2011, Exploration update-West Kytlim: London Stock Exchange RNS no. 08260, September 12, 2 p., accessed June 23, 2015, at http://otp.investis.com/ Utilities/PDFDownload.aspx?Newsid=249594.

Eurasia Mining plc, 2012, Urals alluvial platinum-West Kytlim: Eurasia Mining plc, accessed March 20, 2013, at http://www.eurasiamining.co.uk/operations/uralsalluvial.aspx.

European Commission, 2010, Critical raw materials for the EUReport of the ad-hoc Working Group on defining critical raw materials: European Commission, July, 85 p., accessed February 1, 2013, at http:/web.archive.org/web/20130127055633/ http:/ec.europa.eu/enterprise/policies/raw-materials/files/ docs/report-b_en.pdf. [Critical raw materials list was updated in 2014; see http://ec.europa.eu/growth/sectors/ raw-materials/specific-interest/critical/index_en.htm.]

Evans, D.M., Buchanan, D.L., and Parry, S.J., 1996, Böhmke Reef-Platinum-group element mineralization associated with C1d (Number 2) chromitite of the Great Dyke, Zimbabwe: Institution of Mining and Metallurgy, Transactions, Section B, Applied Earth Science, v. 105, p. 82-88.

Ewert, Wayne, Yassa, Antione, Armstrong, Tracy, Brown, F.H., and Puritch, Eugene, 2008, Technical report and resource estimate on the Ore Fault, Galaxy and Page zones of the Marathon PGM/Gossan Resources JV, Bird River Property, southeast Manitoba-NI 43-101 technical report, prepared for Marathon PGM Corporation [Filing date February 26, 2009]: Brampton, Ontario, Canada, P\&E Mining Consultants Inc., December 1, 103 p. [Also available at http://www.sedar.com.]

Fedorenko, V.A., Lightfoot, P.C., Naldrett, A.J., Czamanske, G.K., Hawkesworth, C.J., Wooden, J.L., and Ebel, D.S., 1996, Petrogenesis of the flood-basalt sequence at Noril'sk, North Central Siberia: International Geology Review, v. 38, no. 2, p. 99-135. [Also available at http://dx.doi.org/10.1080/ 00206819709465327.] 
Ferreira, D.S., and Bisnath, Avinash, 2012, Technical report-The mineral resource estimation for the Platreef for the Boikgantsho project, Limpopo Province, Republic of South Africa - NI 43-101 technical report, prepared for Anooraq Resources Corp.: Bordeaux, South Africa, Kai Batla Minerals, January 31, 68 p. [Also available at http://www.infomine.com/index/pr/PB419081.PDF.]

Ferreira-Filho, C.F., Pimentel.M.M., de Araujo, S.M., and Laux, J.H., 2010, Layered intrusions and volcanic sequences in central Brazil-Geological and geochronological constraints for Mesoproterozoic (1.25 Ga) and Neoproterozoic $(0.79 \mathrm{Ga})$ igneous associations: Precambrian Research, v. 183 , no. 1, December, p. 617-634. [Also available at http://dx.doi.org/10.1016/j.precamres.2010.06.008.]

Ferris, J.K., Storey, B.C., Vaughan, A.P.M., Kyle, P.R., and Jones, P.C., 2003, The Dufek and Forrestal intrusions, Antarctica-A centre for Ferrar large igneous province dike emplacement?: Geophysical Research Letters, v. 30, no. 6, p. 81-1 to 81-4. [Also available at http://dx.doi.org/ 10.1029/2002GL016719.]

Ferris, Julie, Johnson, Ash, and Storey, Bryan, 1998, Form and extent of the Dufek intrusion, Antarctica, from newly compiled aeromagnetic data: Earth and Planetary Science Letters, v. 154, nos. 1-4, January, p. 185-202. [Also available at http://dx.doi.org/10.1016/S0012-821X(97)00165-9.]

Finnigan, C.S., Brenan, J.M., Mungall, J.E., and McDonough, W.F., 2008, Experiments and models bearing in the role of chromite as a collector of platinum-group minerals by local reduction: Journal of Petrology, v. 49, no. 9, p. 1647-1665. [Also available at http://dx.doi.org/10.1093/petrology/egn041.]

Fletcher, R.J., 2009, Independent report on the Shalozerskoe (Burakovsky), Lukkulaisvaara and Tsipringa platinum, palladium, copper, nickel deposits in the Autonomous Republic of Karelia, Russian Federation, prepared for JSC Norit: London, United Kingdom, Behre Dolbear International Ltd., Project 07-112 Norit, 58 p., accessed March 20, 2013, at http:/www.norit-platinum.ru/ Investors/090307\%20J07-112\%20Norit $\% 20$ Draft $\% 20$ Report\%20Part\%201.pdf.

Ford, A.B., 1976, Stratigraphy of the layered gabbroic Dufek intrusion, Antarctica: U.S. Geological Survey Bulletin 1405-D, 36 p. [Also available at http://pubs.er.usgs.gov/ publication/b1405D.]

Ford, A.B., Schmidt, D.L., and Boyd, W.W., Jr., 1978, Geologic map of the Davis Valley quadrangle and part of the Cordiner Peaks quadrangle, Pensacola Mountains, Antarctica: U. S. Geological Survey Antarctic Geologic Map A-10, scale 1:250,000. [Also available at http://pubs.er.usgs.gov/publication/a10.]
Ford, A.B., Schmidt, D.L., Boyd, W.W., Jr., and Nelson, W.H., 1978, Geologic map of the Saratoga Table quadrangle, Pensacola Mountains, Antarctica: U.S. Geological Survey Antarctic Geologic Map A-9, scale 1:250,000. [Also available at http://pubs.er.usgs.gov/publication/a9.]

Frick, C., 1985, A study of the soil geochemistry of the Platreef in the Bushveld Complex: Journal of Geochemical Exploration, v. 24, no. 1, p. 51-80. [Also available at http://dx.doi.org/10.1016/0375-6742(85)90004-4.]

Fryer, B.J., Kerrich, R., Hutchinson, R.W., Peirce, M.G., and Rogers, D.S., 1979, Archaean precious-metal hydrothermal systems, Dome Mine, Abitibi greenstone belt-I -Patterns of alteration and metal distribution: Canadian Journal of Earth Sciences, v. 16, no. 3, p. 421-439. [Also available at http://dx.doi.org/10.1139/e79-040.]

Fuchs, W.A., and Rose, A.W., 1974, The geochemical behavior of platinum and palladium in the weathering cycle in the Stillwater Complex, Montana: Economic Geology, v. 69, p. 332-346. [Also available at http://dx.doi.org/10.2113/ gsecongeo.69.3.332.]

Fugro Robertson, Ltd., 2008, Fugro Tellus sedimentary basins of the world map: AAPG Datapages, accessed August 24, 2015, at http:/www.datapages.com/gis-mappublishing-program/gis-open-files/global-framework/ robertson-tellus-sedimentary-basins-of-the-world-map.

Gammons, C.H., and Bloom, M.S., 1993, Experimental investigation of the hydrothermal geochemistry of platinum and palladium - II - The solubility of PtS and PdS in aqueous sulfide solutions to $300^{\circ} \mathrm{C}$ : Geochimica et Cosmochimica Acta, v. 57, no. 11, p. 2451-2467. [Also available at http://dx.doi.org/10.1016/0016-7037(93)90409-P.]

Gerard, David, and Lave, L.B., 2005, Implementing technology-forcing policies-The 1970 Clean Air Act amendments and the introduction of advanced automotive emissions controls: Technological Forecasting and Social Change, v. 72, no. 7, p. 761-778. [Also available at http://dx.doi.org/10.1016/j.techfore.2004.08.003.]

Geological Survey of Finland, 2010, Platinum-group elements in Finland: Geological Survey of Finland database, accessed September 23, 2011, at http://web.archive.org/ web/20110805035805/http://en.gtk.fi/ExplorationFinland/ Commodities/PGE/pge_database.html. [Also available at http://en.gtk.fi/informationservices/commodities/platinum.html.]

Geological Survey of Finland, 2011, Fennoscandian ore deposit database and metallogenic map: Geological Survey of Finland, accessed March 13, 2013, at http://en.gtk.fi/ export/sites/en/informationservices/databases/fodd/ fodd20111021.xls. (Database content in MS Excel format.) 
Geological Survey of Western Australia, 2004, 1:500,000 interpreted bedrock geology of Western Australia (April 21, 2004 version): Geological Survey of Western Australia, accessed July 6, 2004, at http://web.archive.org/web/ 20040818094334/http://mapserver.mpr.wa.gov.au/datacentre/.

Giblin, P.E., 1984, History of exploration and development, of geological studies and development of geological concepts: Sudbury, Ontario, Canada, Ontario Geological Survey Special Volume 1, p. 1-23.

Glaister, B.J., and Mudd, G.M., 2010, The environmental costs of platinum-PGM mining and sustainability-Is the glass half-full or half-empty?: Mining Engineering, v. 23, no. 5, p. 438-450. [Also available at http://dx.doi.org/10.1016/ j.mineng.2009.12.007.]

Gleeson, S.A., Butt, C.R.M., and Elias, M., 2003, Nickel laterites-A review: SEG Newsletter, no. 54, p. 1, 12-18.

Glen, J.M.G., Schmidt, J.M., and Connard, G.G., 2011, Threedimensional model of an ultramafic feeder system to the Nikolai Greenstone mafic large igneous province, central Alaska Range: Geochemistry Geophysics Geosystems, v. 12 , no. 6,24 p. [Also available at http://dx.doi.org/ 10.1029/2011GC003508.]

Godel, Belinda, Barnes, S.-J., and Maier, W.D., 2007, Platinumgroup elements in sulphide minerals, platinum-group minerals, and whole-rocks of the Merensky Reef (Bushveld Complex, South Africa) - Implications for the formation of the reef: Journal of Petrology, v. 48, no. 8, p. 1569-1604. [Also available at http://dx.doi.org/10.1093/petrology/egm030.]

Goldberg, E.D., and Koide, Minora, 1990, Understanding the marine chemistries of the platinum group metals: Marine Chemistry, v. 30, p. 249-257. [Also available at http://dx.doi.org/10.1016/0304-4203(90)90074-M.]

Green, G.N., and Drouillard, P.H., 1994, The digital geologic map of Wyoming in ARC/INFO format: U.S. Geological Survey Open-File Report 94-425, scale 1:500,000. [Also available at http://pubs.er.usgs.gov/publication/ofr94425.]

Grinenko, L.I., 1985, Sources of sulfur of the nickeliferous and barren gabbro-dolerite intrusions of the Northwest Siberian Platform: International Geology Review, v. 28, no. 6, p. 695-708. [Also available at http://dx.doi.org/ 10.1080/00206818509466457.]

Grokhovskaya, T.L., Lapina, M.I., Ganin, V.A., and Grinevich, N.G., 2005, PGE mineralization in the Burakovsk layered complex, South Karelia, Russia: Geology of Ore Deposits, v. 47, no. 4, p. 283-308. [Translated from Geologiya Rudnykh Mestorozhdenii, v. 47, no. 4, p. 315-341.]
Halbach, P., Kriete, C., Prause, B., and Puteanus, D., 1989, Mechanisms to explain the platinum concentration in ferromanganese seamount crusts: Chemical Geology, v. 76, nos. 1-2, p. 95-106. [Also available at http://dx.doi.org/ 10.1016/0009-2541(89)90130-7.]

Hall, A.L., 1932, The Bushveld igneous complex of the central Transvaal: Pretoria, South Africa, Union of South Africa Dept. of Mines and Industries, Geological Survey of South Africa Memoir 28, $560 \mathrm{p}$.

Hamilton, M.A., and Brooks, C.K., 2004, A precise U-Pb zircon age for the Skaergaard intrusion-Magmatic cooling history refinement and Paleogene igneous correlations, East Greenland [abs.]: American Geophysical Union, Spring Meeting 2004, abstract no. V41A-03, accessed April 4, 2014, at http://adsabs.harvard.edu//abs/2004AGUSM.V41A..03H.

Hanley, J.J., 2005, The aqueous geochemistry of the platinumgroup elements (PGE) in surficial, low-T hydrothermal and high-T magmatic-hydrothermal environments, in Mungall, J.E., ed., Exploration for platinum-group element deposits: Mineralogical Association of Canada Short Course Series, v. 35 , p. $35-56$.

Harper, Fiona, and de Wit, D.R., 2009, The update 2009 National Instrument 43-101 technical report for the Pilanesberg Platinum Mines, North West Province, South Africa for Platmin Limited [Effective date December 31, 2009; final date May 5, 2010]: Johannesburg, South Africa, Venmyn Rand (Pty) Ltd., 64 p. plus 4 appendixes.

Hein, J.R., Koschinsky, Andrea, Bau, Michael, Manheim, F.T., Kang, J.-K., and Roberts, Leanne, 2000, Cobalt-rich ferromanganese crusts in the Pacific, in Cronan, D.S., ed., Handbook of marine mineral deposits: Boca Raton, Fla., CRC Press, p. 239-279.

Hilliard, H.E., 1998, Platinum-group metals: U.S. Geological Survey Mineral Commodity Summaries 1998, p. 126-127. [Also available at http://minerals.er.usgs.gov/minerals/pubs/ commodity/platinum/550398.pdf.]

Hilliard, H.E., 2000, Platinum-group metals: U.S. Geological Survey Mineral Commodity Summaries 2000, p. 126-127. [Also available at https://minerals.usgs.gov/minerals/pubs/ commodity/platinum/550300.pdf.]

Hilliard, H.E., 2004, Platinum-group metals: U.S. Geological Survey Mineral Commodity Summaries 2004, p. 124-125. [Also available at https://minerals.usgs.gov/minerals/pubs/ commodity/platinum/pgmmes04.pdf.]

Himmelberg, G.R., and Loney, R.A., 1981, Petrology of the ultramafic and gabbroic rocks of the Brady Glacier nickelcopper deposit, Fairweather range, southeastern Alaska: U.S. Geological Survey Professional Paper 1195, 26 p. [Also available at http://pubs.usgs.gov/pp/1195/report.pdf.] 
Hirsikko, A., Vakkari, V., Tiitta, P., Manninen, H.E., Gagné, S., Laakso, H., Kulmala, M., Mirme, A., Mirme, S., Mabaso, D., Beukes, J.P., and Laakso, L., 2012, Characterisation of sub-micron particle number concentrations and formation events in the western Bushveld igneous complex, South Africa: Atmospheric Chemistry and Physics, v. 12, no. 9, p. 3951-3967. [Also available at http://dx.doi.org/10.5194/ acp-12-3951-2012.]

Hoaglund, S.A., 2010, U-Pb geochronology of the Duluth Complex and related hypabyssal intrusions - Investigating the emplacement history of a large multiphase intrusive complex related to the $1.1 \mathrm{Ga}$ midcontinent rift: Minneapolis, Minn., University of Minnesota M.S. thesis, $112 \mathrm{p}$.

Hoare, J.M., and Coonrad, W.L., 1978, Geologic map of the Goodnews and Hagemeister Island quadrangles region, southwestern Alaska: U.S. Geological Survey Open-File Report 78-9-B, 2 sheets, scale 1:250,000. [Also available at http://pubs.er.usgs.gov/publication/ofr789B.]

Hoatson, D.M., and Blake, D.H., 2000, Geology and economic potential of the Palaeoproterozoic layered mafic-ultramafic intrusions in the East Kimberley, Western Australia: Australian Geoscience Organization Bulletin 246, 496 p.

Holwell, D.A., and McDonald, Iain, 2010, A review of the behavior of platinum group elements within natural magmatic sulfide ore systems: Platinum Metals Review, v. 54, no. 1, p. 26-36. [Also available at http://dx.doi.org/ 10.1595/147106709X480913.]

Hoppstock, Klaus, and Sures, Bernd, 2004, Platinum-group metals, chap. 20 of Merian, E., Anke, Manfred, Ihnat, M., and Stoeppler, Markus, eds., Elements and their compounds in the environment-Occurrence, analysis, and biological relevance, 2d ed: Weinheim, Germany, Wiley-VCH Verlag GmbH, p. 1047-1086. [Also available at http://dx.doi.org/ 10.1002/9783527619634.]

Houston, R.S., and Orback, C.J., 1976, Geologic map of the Lake Owen Quadrangle, Albany County, Wyoming: U.S. Geological Survey Quadrangle Map GQ-1304, scale 1:24,000. [Also available at http://pubs.er.usgs.gov/ publication/gq1304.]

Hulbert, L.J., 1997, Geology and metallogeny of the Kluane mafic-ultramafic belt, Yukon Territory, Canada-Eastern Wrangellia-A new Ni-Cu-PGE metallogenic terrane: Geological Survey of Canada Bulletin, v. 506, 265 p.

Hulbert, L.J., and Stone, W.E., 2006, Eastern WrangelliaA new Ni-Cu-PGE metallogenic terrane in North America: ASEG Extended Abstracts 2006, no. 1, 7 p. [Also available at http://dx.doi.org/10.1071/ASEG2006ab070.]
Hulbert, L.J., Carne, R.C., Gregoire, D.C., and Paktunc, Dogan, 1992, Sedimentary nickel, zinc and platinum-group-element mineralization in Devonian black shales at the Nick property, Yukon, Canada-A new deposit type: Exploration and Mining Geology, v. 1, no. 1, p. 39-62.

Hulbert, L.J., Duke, J.M., Eckstrand, O.R., Lydon, J.W., Scoates, R.F.J., Cabri, L.J., and Irvine, T.N., 1988, Geological environments of the platinum group elements: Geological Survey of Canada Open File 1440, 148 p. [Also available at http://dx.doi.org/10.4095/130338.]

Hunter, R.H., 1987, Textural equilibrium in layered igneous rocks, in Parson, Ian, ed., Origins of igneous layering: Boston, Mass., D. Reidel Publishing Co., NATO ASI Series, Series C-Mathematical and Physical Sciences, v. 196, p. 473-503.

Hurst, Sarah, 2005, Kamchatka's platinum lures minersRussia lifts veil on secretive platinum industry: The Northern Miner, v. 91, no. 27, accessed April 27, 2013, at http://www.northernminer.com/news/kamchatka-splatinum-lures-miners/1000196934/.

Hutchison, C.S., 1983, Economic deposits and their tectonic setting: New York, N.Y., John Wiley \& Sons, 365 p.

Iljina, M.J., and Lee, C.A., 2005, PGE deposits in the marginal series of layered intrusions, in Mungall, J.E., ed., Exploration for platinum-group element deposits: Mineralogical Association of Canada Short Course Series, v. 35, p. 75-96.

Iljina, Markku, Heikura, Pertti, and Salmirinne, Heikki, 2005, The Haukiaho and Kaukua PGE-Cu-Ni-Au prospects in the Koillismaa layered igneous complex, Finland: Geological Survey of Finland, Mineral Exploration Report M06/3543,3544/2005/1/10, 20 p. plus 3 appendixes. [Also available at http://tupa.gtk.fi/raportti/valtaus/ m06_3543_3544_2005_1_10.pdf.]

Impala Platinum Holdings Ltd., 2011, Mineral resource and mineral reserve statement as at 30 June 2011: Impala Platinum Holdings Ltd., 66 p., accessed September 13, 2012, at http://www.implats.co.za/implats/downloads/2011/ annual\%20reports/Implats\%20MR_Combined_LoRes.pdf.

Impala Platinum Holdings Ltd., 2012, Metals usage: Impala Platinum Holdings Ltd., accessed January 31, 2013, at http://www.implats.co.za/implats/Metals-usage.asp.

Instituto Nacional de Geologica, 1987, Carta geológica [Geologic map of Mozambique]: República Popular de Moçambique, Ministério dos Recursos Minerais, Instituto Nacional de Geologica, 1 map on 2 sheets, scale 1:1,000,000. [In Portuguese.]

International Network for Acid Prevention, 2011, Global acid rock drainage guide: International Network for Acid Prevention, accessed November 10, 2011, at http://www.gardguide.com. 
Ivanic, T.J., Korsch, R.J., Wyche, S., Jones, L.E.A., Zibra, I., Blewett, R.S., Jones, T., Milligan, P., Costelloe, R.D., Van Kranendonk, M.J., Doublier, M.P., Hall, C.E., Romano, S.S., Pawley, M.J., Gessner, K., Patison, N., Kennett, B.L.N., and Chen, S.F., 2013, Preliminary interpretation of the 2010 Youanmi deep seismic reflection lines and magnetotelluric data for the Windimurra igneous complex, in Wyche, S., Ivanic, T.J. and Zibra, I., eds., 2011 Youanmi and Southern Carnavon seismic and magnetotelluric (MT) workshop 2013: Geological Survey of Western Australia, Record 2013/6, p. 97-111.

Ivanplats (Pty) Ltd., 2013, Flatreef discovery expands to 29.2 million ounces of platinum, palladium, rhodium and gold in indicated mineral resources, plus an additional 44.0 million ounces in inferred mineral resources, at a $2.0 \mathrm{~g} / \mathrm{t}$ 4PE cutoff: Ivanplats (Pty) Ltd. press release, February 6, 9 p., accessed March 18, 2013, at https://www.ivanplats.com/assets/docs/nr/2013-02-06_NR.pdf.

Jambor, J.L., Blowes, D.W., and Ptacek, C.J., 2000, Mineralogy of mine wastes and strategies for remediation, in Vaughan, D.J., and Wogelius R.A., eds., Environmental mineralogy: European Mineralogical Union Notes in Mineralogy, v. 2. p. 255-290.

Jebwab, Jacques, 2003, Katanga platinum group minerals: Brussels, Belgium, Université Libre de Bruxelles, accessed April 8, 2013, at http:/www.ulb.ac.be//sciences/katangapgm/.

Jinshan Gold Mines, 2004, Jinshan Gold Mines releases updated resource estimate for JBS platinum/palladium/nickel project, China: Jinshan Gold Mines press release, May 13, 3 p. [Also available at http://www.businesswire.com/news/ home/20040513005173/en/Jinshan-Gold-Mines-ReleasesUpdated-Resource-Estimate\#.VfHviLEpB9M.]

Johan, Z., 2002, Alaskan-type complexes and their platinumgroup element mineralization, in Cabri, L.J., ed., The geology, geochemistry, mineralogy and mineral beneficiation of platinum-group elements: Montreal, Quebec, Canada, Canadian Institute of Mining, Metallurgy and Petroleum Special Volume 54, p. 669-719.

Johnson, R.H., Blowes, D.W., Robertson, W.D., and Jambor, J.L., 2000, The hydrogeochemistry of the Nickel Rim mine tailings impoundment, Sudbury, Ontario: Journal of Contaminant Hydrology, v. 41, nos. 1-2, p. 49-80. [Also available at http://dx.doi.org/10.1016/S0169-7722(99)00068-6.]

Johnston, C., 1962, Platinum mining in Alaska-Dredge and dragline operations at Goodnews Bay: Platinum Minerals Review, v. 6, no. 2, p. 68-74.

Jones, D. L., Irwin, W.P., and Ovenshine, A.T., 1972, Southeastern Alaska-A displaced continental fragment?: U.S. Geological Survey Professional Paper 800-B, p. B211-B217.
Jones, R.T., 2002, ConRoast-DC arc smelting of deadroasted sulphide concentrates, in Third International Sulfide Smelting Symposium (Sulfide Smelting '02), Seattle, Washington, February 17-21, 2002, Proceedings: Randburg, South Africa, Mintek, S.A., Mintek Paper no. 8527, 22 p., accessed April 18, 2013, at http://www.mintek.co.za/ Pyromet/ConRoast/Summary.htm.

Jones, W.R., Peoples, J.W., and Howland, A.L., 1960, Igneous and tectonic structures of the Stillwater Complex, Montana: U.S. Geological Survey Bulletin 1071-H, p. 281-340.

Jubileus, M.T., 2008, Assessment of platinum mine tailings storage facilities - An ecotoxicological perspective: Potchefstroom, South Africa, North-West University, unpublished Master of Science thesis, 113 p.

Kargi, Hulusi, and Barnes, C.G., 1995, A Grenville-age layered intrusion in the subsurface of west TexasPetrology, petrography, and possible tectonic setting: Canadian Journal of Earth Sciences, v. 32, no. 12, p. 2159-2166. [Also available at http://dx.doi.org/ 10.1139/e95-168.]

Keller, G.R., Hills, J.M., Baker, M.R., and Wallin, E.T., 1989, Geophysical and geochronological constraints on the extent and age of mafic intrusions in the basement of west Texas and eastern New Mexico: Geology, v. 17, no. 11, p. 1049-1052.

Kemp, J.F., 1902, The geological relations and distributions of platinum and associated metals: U.S. Geological Survey Bulletin 193, 95 p.

Kennecott Eagle Minerals Co., 2006, Eagle Project mining permit application, volume I: Marquette, Mich., Kennecott Eagle Minerals Co., 126 p., accessed June 23, 2015, at http:/www.lic.wisc.edu/glifwc/Kennecott/permitap2/ Mining/Vol1/Mine\%20Permit\%20App\%20text.pdf.

Kielhorn, Janet, Melber, Christine, Keller, Detlef, and Mangelsdorf, Inge, 2002, Palladium-A review of exposure and effects to human health: International Journal of Hygiene and Environmental Health, v. 205, no. 6, p. 417-432. [Also available at http://dx.doi.org/10.1078/1438-4639-00180.]

Kiousis, G., Economou-Eliopoulos, M., Paspaliaris, I., and Mitsis, I., 2005, Gold, palladium and platinum recovery, as by-products, from the Skouries porphyry $\mathrm{Cu}-\mathrm{Au}$ deposit, Chalkidiki area, northeastern Greece, in Jingwen, Mao, and Bierlein, F.P., eds., Mineral deposit research-Meeting the global challenge - Proceedings of the Eighth Biennial SGA meeting, Beijing, China, August 18-21, 2005: Berlin, Germany, Springer-Verlag, p. 991-994. 
Kirk, L.B., McCleary, Melanie, and Weimer, Randy, 2006, Operational validation of environmental geochemistry at the Stillwater Mine, Nye MT: Billings Land Reclamation Symposium, Billings, Mont., June 4-6, 2006, Presentation, 12 p., accessed June 26, 2013, at http://www.asmr.us/ Publications/Conference Proceedings/2006 Billings/ 0363-Kirk-MT.pdf.

Kleinkopf, M.D., 1985, Regional gravity and magnetic anomalies of the Stillwater Complex area, in Czamanske, G.K., and Zientek, M.L., eds., The Stillwater Complex, MontanaGeology and guide: Montana Bureau of Mines and Geology Special Publication 92, p. 33-38.

Kunilov, V.Ye., 1994, Geology of the Noril'sk region-The history of discovery, prospecting, exploration and mining of the Noril'sk deposits, in Lightfoot, P.C., and Naldrett, A.J., eds., Proceedings of the Sudbury-Noril'sk symposium: Sudbury, Ontario, Canada, Ontario Geological Survey Special Volume 5, p. 203-216.

Lael, R.L., and Killen, Linda, 1982, Pressure of shortagePlatinum policy and the Wilson administration during World War I: The Business History Review, v. 56, no. 4, p. 545-558.

Lahtinen, Jarmo, 1983, Yhteenveto Koillismaan kerrosintruusiokompleksin platinatutkimuksista [Summary Koillismaan layered intrusion complex, platinum studies]: Espoo, Finland, Outokumpu Oy report, 001/3541, 3543, 4523/JJL/83/5, February 18, $221 \mathrm{p}$.

Lapakko, K., and Berndt, M., 2009, Laboratory dissolution of tailings under three different conditions, in Securing the future-Mining, metals \& the environment in a sustainable society, Proceedings of the 8th International Conference on Acid Rock Drainage (ICARD), Skellefteå, Sweden, June 22-26, 2009: International Network for Acid Prevention, v. 1, p. 341-352.

Lapakko, K.A., 1994, Comparison of Duluth Complex rock dissolution in the laboratory and field, in Proceedings of the International Land Reclamation and Mine Drainage Conference and Third International Conference on the Abatement of Acidic Drainage, Pittsburgh, PA, April 24-29, 1994: Washington, D.C., U.S. Bureau of Mines Special Publication SP 06A-94, v. 1, p. 419-428.

Lechler, P.J., and Hsu, L.C., 1989, Review of hydrothermal platinum-group metal deposits with new data from Nevada: Society of Mining Engineers Preprint 89-55, 7 p.

Lechler, P.J., Hsu, L.C., and Hudson, D.M., 1988, Anomalous platinum associated with hydrothermal manganese mineralization at the Gibellini Mine, Fish Creek Range, Nevada: Nevada Bureau of Mines and Geology Open File Report 88-4, 8 p.
Levin, V.Y., Katkalov, A.V., and Laskovenkov, A.F., 2010, [Schedule of guided tours and number of participants in the XI Russian petrographic meeting, August 27-28, 2010]: Ural Branch of the Russian Academy of Sciences, accessed April 19, 2013, at http://conf.uran.ru/Data/18message219.pdf. [In Russian.]

Lewins, J.D., Hunns, S., and Badenhorst, J., 2008, The Kalahari Platinum project, in Rogers, M.H., ed., Platinum in transformation-Proceedings of the Third International Platinum Conference, Sun City, South Africa, October 6-9, 2008: Johannesburg, South Africa, The Southern African Institute of Mining and Metallurgy, p. 355-366.

Li, Chusi, Ripley, E.M., and Naldrett, A.J., 2003, Compositional variations of olivine and sulfur isotopes in the Noril'sk and Talnakh intrusions, Siberia-Implications for ore-forming processes in dynamic magma conduits: Economic Geology, v. 98, p. 69-86. [Also available at http://dx.doi.org/10.2113/gsecongeo.98.1.69.]

Lightfoot, P.C., and Lavigne, M.J., Jr., 1995, Nickel, copper, and platinum group element mineralization in Keweenawan intrusive rocks- -New targets in the Keweenawan of the Thunder Bay region, northwestern Ontario: Ontario Geological Survey Open File Report 5928, 32 p. [Also available at http://www.geologyontario.mndmf.gov.on.ca/ mndmfiles/pub/data/imaging/OFR5928/OFR5928.pdf.]

Likhachev, A.P., 1994, Ore-bearing intrusions of the Noril'sk region, in Lightfoot, P.C., and Naldrett, A.J., eds., Proceedings of the Sudbury-Noril'sk symposium: Sudbury, Ontario, Canada, Ontario Geological Survey Special Volume 5, p. 185-201.

Lishman, K.L., 2009, The acid mine drainage potential of the Platreef, northern limb of the Bushveld Complex, South Africa: Johannesburg, South Africa, University of the Witswatersrand, unpublished Master of Science thesis, $231 \mathrm{p}$.

Listerud, W.H., and Meineke, D.G., 1977, Mineral resources of a portion of the Duluth Complex and adjacent rocks in St. Louis and Lake Counties, northeastern Minnesota: Minnesota Department of Natural Resources, Division of Minerals Report 93, 49 p.

Lodders, Katharina, 2010, Solar system abundances of the elements, in Goswami, Aruna, and Reddy, B.E., eds., Principles and perspectives in cosmochemistry-Lecture notes of the Kodai school on 'Synthesis of elements in stars' held at Kodaikanal Observatory, India, April 29-May 13, 2008 : Berlin, Germany, Springer-Verlag, p. 379-417.

Loferski, P.J., 2012a, Platinum-group metals [advance release], in Metals and minerals: U.S. Geological Survey Minerals Yearbook 2011, v. I, p. 57.1-57.11. [Also available at http://minerals.usgs.gov/minerals/pubs/commodity/ platinum/myb1-2011-plati.pdf.] 
Loferski, P.J., 2012b, Platinum-group metals: U.S. Geological Survey Mineral Commodity Summaries 2012, p. 120-121. [Also available at https://minerals.usgs.gov/minerals/pubs/ commodity/platinum/mcs-2012-plati.pdf.]

Loferski, P.J., 2013a, Platinum-group metals [advance release], in Metals and minerals: U.S. Geological Survey Minerals Yearbook 2012, v. I, p. 57.1-57.12. [Also available at http://minerals.usgs.gov/minerals/pubs/commodity/ platinum/myb1-2012-plati.pdf.]

Loferski, P.J., 2013b, Platinum-group metals: U.S. Geological Survey Mineral Commodity Summaries 2013, p. 120-121. [Also available at https://minerals.usgs.gov/minerals/pubs/ commodity/platinum/mcs-2013-plati.pdf.]

Loferski, P.J., 2013c, Platinum-group metals (Ir, Os, Pd, Pt, $\mathrm{Rh}, \mathrm{Ru}$ ), in Metal prices in the United States through 2010: U.S. Geological Survey Scientific Investigations Report 2012-5188, p. 119-132, available only at http://pubs.usgs.gov/ sir/2012/5188/sir2012-5188.pdf\#Platinum-Group.

Lonmin plc, 2011, Mineral resource and mineral reserve statements-As at September 30, 2011: Lonmin plc, 46 p., accessed September 26, 2012, at https://www.lonmin.com/ downloads/Mineral_Resource_Mineral_Reserve_Statement 30Sep11_FINAL.pdf.

Loucks, R.R., 1991, Platinum-gold and vanadiferous magnetite mineralization in the Early Proterozoic Lake Owen layered mafic intrusion, Medicine Bow Mountains, Wyoming, in Mineral Resources of Wyoming-Wyoming Geological Association Forty-Second Field Conference guidebook, Laramie, Wyo., Sept. 14-18, 1991: Laramie, Wyo., Wyoming Geological Association, v. 42, p. 37-38.

Loucks, R.R., and Glasscock, J.W., 1989, Petrology and PGE mineralization of the early Proterozoic Lake Owen layered mafic intrusion, southern Wyoming, USA: Bulletin of the Geological Society of Finland, v. 61, p. 11-12.

Loukola-Ruskeeniemi, K., 1991, Geochemical evidence for the hydrothermal origin of sulphur, base metals and gold in Proterozoic metamorphosed black shales, Kainuu and Outokumpu areas, Finland: Mineralium Deposita, v. 26, no. 2, p. 152-164. [Also available at http://dx.doi.org/ 10.1007/BF00195262.]

Loukola-Ruskeeniemi, Kristi, and Heino, Timo, 1996, Geochemistry and genesis of the black shale-hosted $\mathrm{Ni}-\mathrm{Cu}-\mathrm{Zn}$ deposit at Talvivaara, Finland: Economic Geology, v. 91, p. 80-110.

Lumb, A.D., 1920, The platinum metals: London, United Kingdom, J. Murray, 63 p., 1 map.

Maboeta, M.S., van Rensburg, Leon, and van Rensburg, P.J., 2008, Earthworm (Eisenia fetida) bioassay to assess the possible effects of platinum tailings disposal facilities on the environment along a gradient: Applied Ecology and Environmental Research, v. 6, no. 2, p. 13-19.
Maier, W.D., and Barnes, S.-J., 2005, Application of lithogeochemistry to exploration for PGE deposits, in Mungall, J.E., ed., Exploration for platinum-group element deposits: Mineralogical Association of Canada Short Course Series, v. 35, p. 309-341.

Maier, W.D., Barnes, S.-J., Ashwal, L.D., and Li, C., 2001, A reconnaissance study on the magmatic $\mathrm{Cu}-\mathrm{Ni}$-PGE sulphide potential of the Tete Complex, Mozambique: South African Journal of Geology, v. 104, no. 4, p. 355-364.

Maier, W.D., Barnes, S.-J., Gartz, Volker, and Andrews, G., 2003, Pt-Pd reefs in magnetitites of the Stella layered intrusion, South Africa-A world of new exploration opportunities for platinum-group elements: Geology, v. 31, no. 10, p. 885-888. [Also available at http://dx.doi.org/ 10.1130/G19746.1.]

Maier, W.D., Peltonen, Petri, McDonald, Ian, Barnes, S.J., Barnes, S.-J., Hatton, Chris, and Viljoen, F., 2012, The concentration of platinum-group elements and gold in southern African and Karelian kimberlite-hosted mantle xenoliths - Implications for the noble metal content of the Earth's mantle: Chemical Geology, v. 302-303, p. 119-135. [Also available at http://dx.doi.org/10.1016/ j.chemgeo.2011.06.014.]

Malitch, K.N., 1999, Platinum-group elements in clinopyroxene-dunite massifs of the East Siberia (geochemistry, mineralogy, and genesis): St. Petersburg, Russia, Saint Petersburg Cartographic Factory VSEGEI Press, 296 p. [In Russian with English abstract.]

Malitch, K.N., and Thalhammer, O.A.R., 2002, Pt-Fe nuggets derived from clinopyroxenite-dunite massifs, RussiaA structural, compositional and osmium-isotope study: Canadian Mineralogist, v. 40, no. 20, p. 395-418. [Also available at http://dx.doi.org/10.2113/gscanmin.40.2.395.]

Malitch, K.N., Badanina, I.Yu., Belousova, E.A., and Tuganova, E.V., 2012, Results of U-Pb dating of zircon and baddeleyite from the Noril'sk-1 ultramafic-mafic intrusion (Russia): Russian Geology and Geophysics, v. 53, no. 2, p. 123-130. [Also available at http://dx.doi.org/10.1016/ j.rgg.2011.12.010.]

Mao, Jingwen, Lehmann, Bernd, Du, Andao, Zhang, Guangdi, Ma, Dongsheng, Wang, Yitian, Zeng, Mingguo, and Kerrich, Robert, 2002, Re-Os dating of polymetallic Ni-Mo-PGE-Au mineralization in Lower Cambrian black shales of south China and its geologic significance: Economic Geology, v. 97, p. 1051-1061. [Also available at http://dx.doi.org/10.2113/gsecongeo.97.5.1051.]

Martini, J.E.J., Vorster, C.J., Oosterhuis, W.R., and Wolmarans, L.G., 2001, Digital metallogenic map of South Africa and the Kingdoms of Lesotho and Swaziland: Council for Geoscience (Geological Survey), South Africa, scale 1:1,000,000, CD-ROM. 
Mathez, E.A., 1999, On factors controlling the concentrations of platinum group elements in layered intrusions and chromitites, in Keays, R.R., Lesher, C.M., Lightfoot, P.C., and Farrow, C.E.G., eds., Dynamic processes in magmatic ore deposits and their application in mineral exploration: Geological Association of Canada Short Course Notes, v. 13 , p. 251-285.

Mathison, C.I., and Ahmat, A.L., 1996, The Windimurra igneous complex, Western Australia, in Cawthorn, R.G., ed., Layered intrusions: Amsterdam, Netherlands, Elsevier Science B.V., p. 485-510. [Also available at http://dx.doi.org/ 10.1016/S0167-2894(96)80016-9.]

Mattera, Philip, 2008, Anglo American's track recordRhetoric or reality? - Community, worker safety, public health, and environmental problems at Anglo American mining operations: Renewable Resources Coalition, 34 p., accessed February 19, 2013, at http://www.infomine.com/ library/publications/docs/Mattera2008.pdf.

Mattila, E., Hugg, R., and Kerkkonen, O., 1976, Mustavaaran kaivoksen jätealtaan Lavotan tutkimukset [Mustavaara Mine tailings pond Lavotan studies] XI-XII v. 1975: Helsinki, Finland, Rautaruukki Oy report OU 1/76, accessed September 21, 2015, at http://tupa.gtk.fi/raportti/ arkisto/ou_1_76.pdf. [In Finnish.]

McBirney, A.R., 1989, Geological map of the Skaergaard intrusion, east Greenland: Eugene, Oregon, University of Oregon, Department of Geology, scale 1:20,000.

McCallum, I.S., Raedeke, L.D., and Mathez, E.A., 1980, Investigations of the Stillwater Complex-Part IStratigraphy and structure of the Banded zone: American Journal of Science, v. 280-A, no. 1, p. 59-87. [Also available at http://earth.geology.yale.edu/ ajs/1980/ ajs_280A_1.pdf/59.pdf.]

McCallum, M.E., Loucks, R.R., Carlson, R.R., Cooley, E.F., and Doerge, T.A., 1976, Platinum metals associated with hydrothermal copper ores of the New Rambler Mine, Medicine Bow Mountains, Wyoming: Economic Geology, v. 71, p. 1429-1450. [Also available at http://dx.doi.org/ 10.2113/gsecongeo.71.7.1429.]

McCarthy, J.E., Copeland, Claudia, Parker, Larry, and Schierow, Linda-Jo, 2011, Clean Air Act-A summary of the Act and its major requirements: Washington, D.C., Congressional Research Service Report RL30853, January $6,24 \mathrm{p}$.

McConnachie, Terry, Trevarthen, Nigel, and Carroll, Louis, 2011, Success, growth, introducing Sylvania Platinum: Sylvania Platinum Ltd. Investor Relations presentation, April 4, 25 p., accessed February 25, 2013, at http://www.sylvaniaplatinum.com/im/files/documents/ 040411-SLP-Investor-Presentation-ASX.pdf.
McCracken, Todd, 2011, Technical report and resource estimate on the Wellgreen platinum-palladium-nickel-copper project, Yukon, Canada, prepared for Prophecy Platinum Corp: Toronto, Ontario, Canada, Tetra Tech Wardrop, Document no. 1155400200-REP-R0001-03, September 15, 91 p.

McCracken, Todd, 2012, Technical report and resource estimate on the River Valley PGM project, northern Ontario-NI 43-101 technical report, prepared for Pacific North West Capital Corp. [Filing date June 14, 2012]: Toronto, Ontario, Canada, Tetra Tech Wardrop, Document No. 1193250100-REP-R0001-01, June 13, 114 p. plus 2 appendixes. [Also available at http://www.sedar.com.]

McDonald, Donald, and Hunt, L.B., 1982, History of platinum and its allied metals: London, United Kingdom, Johnson Matthey Plc, 450 p., accessed October 29, 2015, at https://books.google.co.uk/books?id=xriMAgAAQBAJ\& printsec $=$ frontcover\&hl $=\mathrm{en} \# \mathrm{v}=$ onepage $\& \mathrm{q} \& \mathrm{f}=$ false .

McGregor, R.G., Blowes, D.W., Jambor, J.L., and Robertson, W.D., 1998, Mobilization and attenuation of heavy metals within a nickel mine tailings impoundment near Sudbury, Ontario, Canada: Environmental Geology, v. 36, p. 305-319. [Also available at http://dx.doi.org/10.1007/s002540050346.]

Meck, Maideyi, Love, David, and Mapani, Benjamin, 2006, Zimbabwean mine dumps and their impacts on river water quality - A reconnaissance study: Physics and Chemistry of the Earth, Parts A/B/C, v. 31, nos. 15-16, p. 797-803. [Also available at http://dx.doi.org/10.1016/j.pce.2006.08.029.]

Meeks, N., La Niece, S., and Estévez, P., 2002, The technology of early platinum plating - A gold mask of the La Tolita culture, Ecuador: Archaeometry, v. 44, no. 2, p. 273-284. [Also available at http://dx.doi.org/10.1111/1475-4754.t01-1-00059.]

Mehta, Viral, and Cooper, J.S., 2003, Review and analysis of PEM fuel cell design and manufacturing: Journal of Power Sources, v. 114, p. 32-53. [Also available at http://dx.doi.org/ 10.1016/S0378-7753(02)00542-6.]

Mertie, J.B., Jr., 1969, Economic geology of the platinum metals: U.S. Geological Survey Professional Paper 630, 120 p. [Also available at http://pubs.er.usgs.gov/publication/pp630.)

Mertie, J.B., Jr., 1976, Platinum deposits of the Goodnews Bay District, Alaska: U.S. Geological Survey Professional Paper 938, 42 p. [Also available at http://pubs.er.usgs.gov/ publication/pp938.]

Meyers, J.S., 1985, The Fraser Complex-A major layered intrusion in Western Australia: Geological Survey of Western Australia Report 14, p. 57-66.

Miller, J.D., Jr., 1999, Geochemical evaluation of platinum group element (PGE) mineralization in the Sonju Lake intrusion, Finland, Minnesota: Minnesota Geological Survey Information Circular 44, 31 p. [Also available at http://purl.umn.edu/59409.] 
Miller, J.D., Jr., Green, J.C., Severson, M.J., Chandler, V.W., Hauck, S.A., Peterson, D.M., and Wahl, T.E., 2002, Geology and mineral potential of the Duluth Complex and related rocks of northeastern Minnesota: Minnesota Geological Survey Report of Investigations 58, 207 p.

Minnesota Department of Natural Resources and the U.S. Army Corps of Engineers, 2009, NorthMet project draft environmental impact statement, 3 vols.: St. Paul, Minn., Minnesota Department of Natural Resources, accessed May 30, 2013, at http://www.dnr.state.mn.us/ input/environmentalreview/polymet/eis_toc.html.

Mitchell, W.I., comp., 1983, Mapa geologico del area de Santo Corazon-Robore (CUAD SE 21-5 con parte de SE 21-9): Institute of Geological Sciences, Natural Environmental Research Council, United Kingdom, and Servicio Geológico de Bolivia, Proyecto Precambrico, Santo Corazon-Robore sheet, Bolivia, 1 sheet, scale 1:250,000.

Mitrofanov, F.P., Korchagin, A.U., and Lobov, S.G., 2007, PGE Fedorova project-Russia, Kola Peninsula, Lovozero area: 6th Fennoscandian Exploration and Mining meeting, November 27-29, 2007, Rovaniemi, Finland, accessed February 20, 2010, at http:/www.lapinliitto.fi/fem2007/ presentations/14lobov.pdf.

Mitrofanov, F.P., Korchagin, A.U., Dudkin, K.O., and Rundkvist, T.y.V., 2005, Fedorov-Pana layered mafic intrusion (Kola Peninsula, Russia)_Approaches, methods, and criteria for prospecting PGEs, in Mungall, J.E., ed., Exploration for platinum-group element deposits: Mineralogical Association of Canada Short Course Series, v. 35, p. 343-358.

Moldovan, Mariella, Rauch, Sébastien, Gómez, Milagros, Palacios, M.A., and Morrison G.M., 2001, Bioaccumulation of palladium, platinum and rhodium from urban particulates and sediments by the freshwater isopod Asellus aquaticus: Water Research, v. 35, no. 17, p. 4175-4183. [Also available at http://dx.doi.org/10.1016/S0043-1354(01)00136-1.]

Molly, E.W., 1959, Platinum deposits of Ethiopia: Economic Geology, v. 54, p. 467-477. [Also available at http://dx.doi.org/ 10.2113/gsecongeo.54.3.467.]

Montana Department of Environmental Quality, 2012a, Montana numeric water quality standards: Helena, Mont., Montana Department of Environmental Quality Circular DEQ-7, 76 p., accessed July 18, 2016, at https:/deq.mt.gov/Portals/112/Water/WQPB/ Standards/PDF/DEQ7/FinalApprovedDEQ7.pdf.

Montana Department of Environmental Quality, 2012b, Stillwater Mining Company's revised water management plans and Boe Ranch LAD_Final Environmental Impact StatementAppendices: Montana Department of Environmental Quality, 239 p., accessed October 6, 2016, at https://deq.mt.gov/ portals/112/DEQAdmin/EIS/Stillwater/Appendices_Final_ Web.pdf.
Montemurro, D., comp., 1984, Mapa geologico del area de Rincon del Tigre-La Gaiba (CUAD SE 21-6 con parte de SE 21-10): Institute of Geological Sciences, Natural Environmental Research Council, United Kingdom, and Servicio Geológico de Bolivia, Proyecto Precambrico, Rincon del Tigre-La Gaiba sheet, Bolivia, 1 sheet, scale 1:250,000.

Mortensen, J.K., and Hulbert, L.J., 1992, A U-Pb zircon age for a Maple Creek gabbro sill, Tatamagouche area, southwest Yukon Territory: Geological Survey of Canada Paper 91-2, p. 175-179.

Mudd, G.M., 2010, Global trends and environmental issues in nickel mining - Sulfides versus laterites: Ore Geology Reviews, v. 38, nos. 1-2, p. 9-26. [Also available at http://dx.doi.org/10.1016/j.oregeorev.2010.05.003.]

Mudd, G.M., 2012, Key trends in the resource sustainability of platinum group elements: Ore Geology Reviews, v. 46, p. 106-117. [Also available at http://dx.doi.org/10.1016/ j.oregeorev.2012.02.005.]

Muehlberger, W.R., comp., 1997, Tectonic map of North America: American Association of Petroleum Geologists Datapages 473, scale 1:5,000,000, CD-ROM.

Mungall, J., 2002, A model for co-precipitation of platinumgroup minerals with chromite from silicate melts [abs.]: 9th International Platinum Symposium, International Geologic Correlation Program, July 21-25, Billings, Mont., IGCP Project 427, 4 p.

Mungall, J.E., 2005, Magmatic geochemistry of the platinumgroup elements, in Mungall, J.E., ed., Exploration for platinum-group element deposits: Mineralogical Association of Canada Short Course Series, v. 35, p. 1-34.

Murahwi, Charley, San Martin, A.J., Gowans, R.M., and Spooner, Jane, 2011, Technical report on the updated mineral resource estimate for the Eagle's Nest property, McFaulds Lake Project, James Bay Lowlands, Ontario, Canada-NI 43-101 technical report, prepared for Noront Resources Ltd. [Filing date April 18, 2011]: Toronto, Ontario, Canada, Micon International Ltd., March 4, 106 p. plus 3 appendixes. [Also available at http://www.sedar.com.]

Myers, J.S., 1976, Stratigraphy of the Fiskenaesset anorthosite complex, southern West Greenland, and comparison with the Bushveld and Stillwater complexes: Grønlands Geologiske Undersøgelse Rapport, v. 80, p. 87-92.

Myers, J.S., 1985, Stratigraphy and structure of the Fiskenaesset Complex, southern West Greenland: Grønlands Geologiske Undersøgelse Rapport, v. 150, 72 p.

Naldrett, A.J., 2006, On the use of geochemistry to characterise mineralisation of magmatic sulfide deposits from around the world-Revised (November 10th 2006) interim report: European Network of Forensic Science Institutes, 30 p., accessed March 27, 2013, at http:/www.enfsi.eu/sites/default/files/ documents/appendix_06_geochemistry_to_characterise_ mineralisation_0.pdf. 
Naldrett, A.J., 2010a, From the mantle to the bank-The life of a Ni-Cu-(PGE) sulfide deposit: South African Journal of Geology, v. 113, no. 1, p. 1-32. [Also available at http://dx.doi.org/10.2113/gssajg.113.1-1.]

Naldrett, A.J., 2010b, Secular variation of magmatic sulfide deposits and their source magmas: Economic Geology, v. 105, p. 669-688. [Also available at http://dx.doi.org/ 10.2113/gsecongeo.105.3.669.]

Naldrett, A.J., Wilson, Allan, Kinnaird, Judith, and Chunnett, Gordon, 2009, PGE tenor and metal ratios within and below the Merensky Reef, Bushveld ComplexImplications for its genesis: Journal of Petrology, v. 50, no. 4, p. 625-659. [Also available at http://dx.doi.org/ 10.1093/petrology/egp015.]

National Research Council of the National Academies, 2008, Minerals, critical minerals, and the U.S. economy: Washington, D.C., National Academies Press, 245 p.

Natural Earth, 2014, Small scale data: Natural Earth map dataset, scale 1:110,000,000, accessed June 23, 2014, at http://www.naturalearthdata.com.

Naus-Thijssen, F.M.J., 2007, Dynamics of igneous systemsBackground: Orono, Maine, University of Maine, Department of Earth Sciences Web page, accessed April 2, 2014 , at http://www.geology.um.maine.edu/user/Felice_Naus thijssen/FDmodule/html\%20pages/background.html.

Nielsen, T.F.D., Andersen, J.C.O., and Brooks, C.K., 2005, The Platinova Reef of the Skaergaard intrusion, in Mungall, J.E., ed., Exploration for platinum-group elements deposits: Mineralogical Association of Canada Short Course Series, v. 35, p. 431-455.

Nitkina, E.A., 2006, U-Pb zircon dating of rocks of the platiniferous Fedorova-Pana layered massif, Kola Peninsula: Doklady Earth Sciences, v. 408, no. 1, p. 551-554. [Also available at http://dx.doi.org/10.1134/S1028334X06040106.]

Nixon, G.T., 2003, Platinum-group elements in the Afton $\mathrm{Cu}-\mathrm{Au}$ porphyry deposit, southern British Columbia: British Columbia Geological Survey Series 2004-1, Geological Fieldwork 2003, p. 263-290.

Noguez, M., Gargia, R., Salas, G., Robert, T., and Ramirez, J., 2006, About the pre-Hispanic Au-Pt "sintering" technique for making alloys: JOM [Journal of the Minerals, Metals, \& Materials Society], v. 58, no. 5, p. 38-43. [Also available at http://dx.doi.org/10.1007/s11837-006-0021-0.]

Nokleberg, W.J., Plafker, George, and Wilson, F.H., 1994, Geology of southcentral Alaska, in Plafker, George, and Berg, H.C., eds., The geology of Alaska: Boulder, Colo., Geological Society of America, Geology of North America series, v. G-1, p. 311-366.
North American Palladium Ltd., 2012, North American Palladium Ltd.-O Operations_-Lac des Iles Mine-Reserves \& resources: Toronto, Ontario, Canada, North American Palladium Ltd. Web page, accessed March 15, 2013, at http://www.napalladium.com/operations/reserves-andresources/.

Northam Platinum Ltd., 2008, Sustainable development report 2008: Thabazimbi, South Africa, Northam Platinum Ltd., 36 p., accessed October 29, 2015, at http://www.northam.co.za/investors-and-media/ publications/sustainable-development-reports.

Oberthür, Thomas, 2002, Platinum-group element mineralization of the Great Dyke, Zimbabwe, in Cabri, L.J., ed., The geology, geochemistry, mineralogy and mineral beneficiation of platinum-group elements: Montreal, Quebec, Canada, Canadian Institute of Mining, Metallurgy and Petroleum Special Volume 54, p. 483-506.

Oberthür, Thomas, Davis, D.W., Blenkinsop, T.G., and Höhndorf, Axel, 2002, Precise U-Pb mineral ages, Rb-Sr and Sm-Nd systematics for the Great Dyke, Zimbabweconstraints on Late Archean events in the Zimbabwe craton and Limpopo belt: Precambrian Research, v. 113, nos. 3-4, p. 293-305. [Also available at http://dx.doi.org/10.1016/ S0301-9268(01)00215-7.]

OJSC MMC Norilsk Nickel, 2009, Annual report 2009-Focus on efficiency: Moscow, Russia, OJSC MMC Norilsk Nickel, 255 p., accessed March 14, 2013, at http://www.nornik.ru/ _upload/year2009/GO_NN_2009_Eng_site.pdf.

OJSC MMC Norilsk Nickel, 2011, Mineral reserves and resources statement: Moscow, Russia, OJSC MMC Norilsk Nickel Web page, accessed March 8, 2013, at http://www.nornik.ru/ en/our_products/MineralReservesResourcesStatement/.

OJSC MMC Norilsk Nickel, 2012, Investor presentationJuly 2012: Moscow, Russia, OJSC MMC Norilsk Nickel, 27 p., accessed March 8, 2013, at http://www.nornik.ru/ _upload/editor_files/file1883.pdf.

Oommen, Thomas, 2006, Geodatabase development and GIS based analysis for resource assessment of placer platinum in the offshore region of Goodnews Bay, Alaska: Fairbanks, Alaska, University of Alaska Master's thesis, 183 p.

Oommen, Thomas, Prakash, Anumpa, Misra, Debasmita, Naidu, Sathy, Kelley, J.J., and Bandopadhyay, Sukumar, 2008, GIS based marine platinum exploration, Goodnews Bay region, southwest Alaska: Marine Georesources and Geotechnology, v. 26, no. 1, p. 1-18. [Also available at http://dx.doi.org/10.1080/10641190701706270.]

Organisation Internationale des Constructeurs d'Automobiles, 2013, Production statistics: Paris, France, Organisation Internationale des Constructeurs d'Automobiles, accessed April 8, 2013, at http://oica.net/category/production-statistics. 
Orth, C.J., Quintana, L.R., Gilmore, J.S., Barrick, J.E., Haywa, J.N., and Spesshardt, S.A., 1988, Pt-group metal anomalies in the Lower Mississippian of southern Oklahoma: Geology, v. 16, no. 7, p. 627-630.

Pacific North West Capital Corp., 2006, Pacific North West Capital acquires Goodnews Bay platinum project, Alaska: Vancouver, British Columbia, Canada, Pacific North West Capital Corp. news release, April 12, 3 p.

Pagé, Philippe, Barnes, S.-J., Bedard, J.H., and Zientek, M.L., 2012, In situ determination of Os, Ir, and Ru in chromites formed from komatiite, tholeiite and boninite magmas-Implications for chromite control of Os, Ir, and Ru during partial melting and crystal fractionation: Chemical Geology, v. 302-303, p. 3-15. [Also available at http://dx.doi.org/10.1016/j.chemgeo.2011.06.006.]

Park, J.W., Hu, Z., Gao, S., Campbell, I.H., and Gong, H., 2012, Platinum group element abundances in the upper continental crust revisited-New constraints from analyses of Chinese loess: Geochimica et Cosmochimica Acta, v. 93, p. 63-76. [Also available at http://dx.doi.org/10.1016/ j.gca.2012.06.026.]

Parker, Harry, and Eggleston, Ted, 2012, Maturi, Birch Lake, and Spruce Road Cu-Ni-PGE projects, Ely, Minnesota USA, NI 43-101 technical report, prepared for Duluth Metals Ltd. [Effective date September 15, 2012]: Sparks, Nev., AMEC E\&C Services Inc., 301 p.

Parks, Jenny, 1998, The Weld Range platinum group element deposit, in Berkman, D.A., and Mackenzie, D.H., eds., Geology of Australian and Papua New Guinean mineral deposits: Australasian Institute of Mining and Metallurgy, Monograph 22, p. 279-286.

Parks, Jenny, and Hill, R.E.T., 1986, Phase compositions and cryptic variation in a $2.2-\mathrm{km}$ section of the Windimurra layered gabbroic intrusion, Yilgarn Block, Western Australia-A comparison with the Stillwater Complex: Economic Geology, v. 81, p. 1196-1202.

Perring, R.J., and Vogt, J.H., 1991, The Panton Sill, chap. 7 of Barnes, S.-J., and Hill, R.E.T., eds., Mafic-ultramafic complexes of Western Australia-Sixth International Platinum Symposium Guidebook for the post-symposium field excursion: Perth, Western Australia, Australia, Geological Society of Australia Excursion Guidebook 3, p. 97-107.

Peterson, D.M., and Severson, M.J., 2002, Chapter 4, Archean and Paleoproterozoic rocks that form the footwall of the Duluth Complex, chap. 4 of Miller, J.D., Jr., Green J.C., Severson, M.J., Chandler, V.W., Hauck, S.A., Peterson, D.M., and Wahl, T.E., 2002, Geology and mineral potential of the Duluth Complex and related rocks of northern Minnesota: Minnesota Geological Survey Report of Investigations RI-58, p. 76-93.
Petrov, G.V., Boduen, A.J., Mardari, I.I., Ivanov, B.S., and Boginskaya, A.S., 2013, Resources of precious metals in technogenic objects of mining and metallurgical complex of Russia: International Journal of Experimental Education, no. 2, p. 54-57.

Petrov, O., Shatov, V., Kondian, K., Markov, G., Guriev, G., Seltmann, R., and Armstrong, R., eds., 2007, Mineral deposits of the Urals 1M scale map and databaseArcView 3.2 GIS package: London, United Kingdom, Natural History Museum Center for Russian and Central Asian Mineral Studies, 91 p., scale 1:1,000,000.

Pieczonka, J., Piestrzyński, A., Mucha, J., Gluszek, A., Kotarba, M.J., and Wieclaw, D., 2008, The red-bed-type precious metal deposit in the Sieroszowice-Polkowice copper mining district, SW Poland: Annales Societatis Geologorum Poloniae, v. 78, no. 3, p. 151-280.

Pimentel, M.M., Ferreira-Filho, C.F., and Armele, Alan, 2006, Neoproterozoic ages of the Niquelândia Complex, central Brazil-Further ID-TIMS U-Pb and Sm-Nd isotopic evidence: Journal of South American Earth Sciences, v. 21, no. 3, July, p. 228-238. [Also available at http://dx.doi.org/ 10.1016/j.jsames.2006.05.001.]

Plafker, George, and Berg, H.C., 1994, Overview of the geology and tectonic evolution of Alaska, in Plafker, George, and Berg, H.C., eds., The geology of Alaska: Boulder, Colo., The Geological Society of America, The Geology of North America series, v. G1, p. 989-1021.

Platina Resources Ltd., 2006, Prospectus: Varsity Lakes, Queensland, Australia, Platina Resources Ltd., 111 p.

Platina Resources Ltd., 2010, Munni Munni, WA: Varsity Lakes, Queensland, Australia, Platina Resources Ltd. Factsheet, 3 p., accessed September 23, 2011, at http://www.platinaresources.com.au/files/projects/ PC00316_Platina_Factsheet_MUNNI_MUNNI_LR.pdf.

Platina Resources Ltd., 2013, 5000 m drill program planned for Owendale platinum \& scandium project: Varsity Lakes, Queensland, Australia, Platina Resources Ltd. news release, February 6, 5 p., accessed March 15, 2013, at http:/www.platinaresources.com.au/files/announcements/ 20130206__PGM_ASX_-_Owendale_Project_Update.pdf.

Platinum Australia Ltd., 2003, Annual report 2003: West Perth, Western Australia, Australia, Platinum Australia Ltd., 37 p., accessed September 9, 2004, at http://www.gtp.com.au/ platinumaus/inews_files/Final_Annual_Report03.pdf.

Platinum Australia Ltd., 2011, Annual report for the year ended 30 June 2011: West Perth, Western Australia, Australia, Platinum Australia Ltd., 79 p., accessed October 4, 2012, at http://www.gtp.com.au/platinumaus/ inews_files/ANNUAL\%20REPORT\%202011_130911.pdf. 
Platinum Australia Ltd., 2012, Quarterly report for the period ended 31 March 2012: West Perth, Western Australia, Australia, Platinum Australia Ltd., April 30, 12 p., accessed September 10, 2015, at http://www.gtp.com.au/platinumaus/ inews_files/QR\%2031\%20MARCH\%202012\%20(jdl2).pdf.

Platinum Today, 2008, The South Africa power situation: Johnson Matthey Plc, accessed February 15, 2013, at http:/www.platinum.matthey.com/media-room/our-viewon-.-.-./the-south-african-power-situation/.

Platinum Today, 2012, Price charts [1992 to 2012]: Royston, United Kingdom, Johnson Matthey Plc, accessed August 28, 2015, at http://www.platinum.matthey.com/ prices/price-charts.

Platinum Today, 2013a, Platinum today-Applications: Royston, United Kingdom, Johnson Matthey Plc, accessed January 31, 2013, at http://www.platinum.matthey.com/ applications/.

Platinum Today, 2013b, Platinum today_Jewellery: Royston, United Kingdom, Johnson Matthey Plc, accessed April 15, 2013, at www.platinum.matthey.com/about-pgm/ applications/jewellery.

Platinum Today, 2013c, Platinum today-Market data tables: Royston, United Kingdom, Johnson Matthey Plc, accessed February 20, 2013, at http://www.platinum.matthey.com/ publications/market-data-tables.

Platmin Ltd., 2011, Annual report for the year ended December 31, 2010: Platmin Ltd., 96 p., accessed October 5, 2012, at http:/www.platmin.com/content/ reports/platmin-annual-report-2010.pdf. [Company name changed to Sedibelo Platinum Mines Ltd. in 2013.]

Plunkert, P.A., and Jones, T.S., comps., 1999, Metal prices in the United States through 1998: U.S. Geological Survey, 179 p. [Also available at http://minerals.usgs.gov/minerals/ pubs/metal_prices/.]

Podmore, F., and Wilson, A.H., 1987, A reappraisal of the structure, geology and emplacement of the Great Dyke, Zimbabwe, in Halls, H.C., and Fahrig, W.F., eds., Mafic dyke swarms: Geological Association of Canada Special Paper, v. 34, p. 317-330, folded color map.

Postle, J.T., Roscoe, W.E., Watanabe, R.Y., and Martin, P.S., 1986, Review of platinum group element deposits in Ontario: Ministry of Northern Development and Mines, Mines and Minerals Division, Mineral Policy Background Paper no. 24, 87 p. [Also available at http:/www.geology ontario.mndmf.gov.on.ca/mndmfiles/pub/data/imaging/ MPBP024/MPBP024.pdf.]
Premo, W.R., Helz, R.T., Zientek, M.L., and Langston, R.B., 1990, U-Pb and Sm-Nd ages for the Stillwater Complex and its associated sills and dikes, Beartooth Mountains, Montana-Identification of a parent magma?: Geology, v. 18, no. 11, p. 1065-1068. [Also available at http://dx.doi.org/ 10.1130/0091-7613(1990)018<1065:UPASNA>2.3.CO;2.]

Prendergast, M.D., 2000, Layering and precious metals mineralization in the Rincón del Tigre Complex, eastern Bolivia: Economic Geology, v. 95, p. 113-130.

Prendergast, M.D., 2012, The Molopo Farms complex, southern Botswana-A reconsideration of structure, evolution, and the Bushveld connection: South African Journal of Geology, v. 115, no. 1, p. 77-90. [Also available at http://dx.doi.org/10.2113/gssajg.115.1.77.]

Prendergast, M.D., and Wilson, A.H., 1989, The Great Dyke of Zimbabwe-II-Mineralization and mineral deposits, in Prendergast, M.D., and Jones, M.J., eds., Magmatic sulphides_-The Zimbabwe volume: London, United Kingdom, Institution of Mining and Metallurgy, p. 21-42.

Prevec, S.A., 1997, Magmatic ore deposits of the Sudbury igneous complex, in Institute on Lake Superior GeologyProceedings of the 43rd annual meeting, Sudbury, Ontario, Canada, May 6-11, 1997: Sudbury, Ontario, Canada, Institute on Lake Superior Geology, v. 43, part 5, 33 p., accessed January 31, 2013, at http://www.d.umn.edu/ prc/lakesuperiorgeology/Volumes/ILSG_43_1997_pt5 Sudbury.CV.pdf.

Price, W.A., 2009, Prediction manual for drainage chemistry from sulphidic geologic materials: Ottawa, Ontario, Canada, CANMET Mining and Mineral Sciences Laboratories, Natural Resources Canada, MEND Report 1.20.1, 579 p. [Also available at http://www.fs.usda.gov/Internet/ FSE_DOCUMENTS/stelprdb5336546.pdf.]

Prichard, H.M., and Lord, R.A., 1993, An overview of the PGE concentrations in the Shetland ophiolite complex, in Prichard, H.M., Alabaster, T., Harris, N.B.W., and Neary, C.R., eds., Magmatic processes and plate tectonics: Geological Society of London Special Publications, v. 76, p. 273-294. [Also available at http://dx.doi.org/10.1144/ GSL.SP.1993.076.01.13.]

Proenza, J.A., Galí, S., Labrador, M., Tauler, E., Zaccarini, F., Garuti, G., Lewis, J.F., and Longo, F., 2010, Platinum group minerals in the saprolitic horizon of Falcondo Ni-laterite deposits, Dominican Republic, in Brown, G.H., Jugo, P.J., Lesher, C.M., and Mungall, J.E., eds., 2010, Abstracts, 11th International Platinum Symposium, June 21-24, 2010, Sudbury, Ontario, Canada: Ontario Geological Survey, Miscellaneous Release-Data 269, 4 p., accessed March 29, 2013, at http://www.geologyontario.mndmf.gov.on.ca/mndmfiles/pub/ data/imaging/mrd269/MRD269.pdf. 
Pure Nickel, Inc., 2013, Factsheet: Pure Nickel Inc., 2 p., accessed April 28, 2013, at http:/www.purenickel.com/ i/pdf/FactSheet.pdf.

Puritch, E.J., Hayden, A.S., Davie, M.J., Brady, Bruce, Ewert, Wayne, Tourangeau, Serge, and Boucher, Sylvain, 2006, Technical report and preliminary economic assessment on the Mequillon, Mesamax, Expo and Ivakkak deposits, Raglan South Nickel Project, Nunavik, QuebecNI 43-101 and NI 43-101F1 technical report and preliminary economic assessment, prepared for Canadian Royalties Inc. [Filing date April 2, 2007]: Brampton, Ontario, Canada, P\&E Mining Consultants Inc. and Roche Ltd., Consulting Group, P\&E Report no. 113, May 5, 2006 (revised as of July 24, 2006), 162 p. and 4 appendixes. [Also available at http://www.sedar.com.]

Pushkarev, E.V., 2001, [Earth sciences-Platinum of the Urals]: Soros Educational Journal, v. 7, no. 11, p. 86-93, accessed April 16, 2013, at http://uralgold.ru/wiki/library/ Platina-Urala.pdf. [In Russian.]

Pushkarev, Evgeny, and Anikina, Elena, 2002, Low temperature origin of the Ural-Alaskan type platinum depositsGeological, mineralogical and geochemical evidence: 9th International Platinum Symposium, International Geologic Correlation Program, July 21-25, Billings, Montana, IGCP Project 427, 4 p.

Raedeke, L.D., and McCallum, I.S., 1984, Investigations in the Stillwater Complex-Part II. Petrology and petrogenesis of the Ultramafic series: Journal of Petrology, v. 25, no. 2, p. 395-420. [Also available at http://dx.doi.org/10.1093/ petrology/25.2.395.]

Rasilainen, Kalevi, Eilu, Paso, Halkoaho, Tapio, Iljina, Markku, and Karinen, Tuomo, 2010, Quantitative mineral resource assessment of platinum, palladium, gold, nickel, and copper in undiscovered PGE deposits in mafic-ultramafic layered intrusions in Finland: Geological Survey of Finland, Report of Investigation 180, 338 p., accessed September 4, 2015, via http://hakku.gtk.fi/en/reports.

Rauch, Sebastien, and Fatoki, O.S., 2013, Anthropogenic platinum enrichment in the vicinity of mines in the Bushveld igneous complex, South Africa: Water Air \& Soil Pollution, v. 224, no. 1395, 8 p. [Also available at http://dx.doi.org/10.1007/s11270-012-1395-y.]

Ravindra, Khaiwal, Benes, László, and Van Grieken, René, 2004, Platinum group elements in the environment and their health risk: Science of the Total Environment, v. 318, nos. 1-3, p. 1-43. [Also available at http://dx.doi.org/ 10.1016/S0048-9697(03)00372-3.]
Realm Resources Ltd., 2011, Quarterly report to 30 June 2011: Sydney, New South Wales, Australia, Realm Resources Ltd. media release, 15 p., accessed July 26, 2012, at http://realmresources.com.au/IRM/Company/ ShowPage.aspx?CPID $=1174 \& E I D=45533987$.

Reese, R.G., Jr., 1996, Platinum-group metals: U.S. Geological Survey Mineral Commodity Summaries 1996, p. 124-125. [Also available at http://minerals.usgs.gov/minerals/pubs/ commodity/platinum/platimcs96.pdf.]

Reichow, M.K., Pringle, M.S., Al'Mukhamedov, A.I., Allen, M.B., Andreichev, V.L., Buslov, M.M., Davies, C.E., Fedoseev, G.S., Fitton, J.G., Inger, S., Medvedev, A.Ya., Mitchell, C., Puchkov, V.N., Safonova, I.Yu., Scott, R.A., and Saunders, A.D., 2009, The timing and extent of the eruption of the Siberian Traps large igneous provinceImplications for the end-Permian environmental crisis: Earth and Planetary Science Letters, v. 277, nos. 1-2, p. 9-20. [Also available at http://dx.doi.org/10.1016/ j.epsl.2008.09.030.]

Riese, W.C., and Arp, G.K., 1983, Biogeochemical prospecting in the Stillwater $(\mathrm{Pt})$ Complex, Montana, in Roberts, Sheila, ed., Metallic and nonmetallic deposits of Wyoming and adjacent areas, 1983 conference proceedings: The Geological Survey of Wyoming, Public Information Circular no. 25, p. 58-65.

Ripley, E.M., 1999, Systematics of sulphur and oxygen isotopes in mafic igneous rocks and related $\mathrm{Cu}-\mathrm{Ni}$-PGE mineralization, in Keays, R.R., Lesher, C.M., Lightfoot, P.C., and Farrow, C.E.G., eds., Dynamic processes in magmatic ore deposits and their application in mineral exploration: Geological Association of Canada Short Course Series, v. 13, p. $133-158$.

Rossell, Dean, and Coombes, Steven, 2005, The geology of the Eagle nickel-copper deposit, Michigan, USA, in Appendix $\mathrm{C}$ - Geologic and geotechnical reports for the Eagle Project, prepared for Kennecott Minerals Co., April 29, 34 p., accessed March 11, 2013, at http://www.lic.wisc.edu/glifwc/Kennecott/permitap2/ Mining/Vol1/Vol1A/Eagle Deposit.pdf.

Rouillard, Paul, 1997, Paths to plenty_-The roots of the economic boom in South Africa during the 1960s: Durban, South Africa, University of Natal, Durban, Bachelor of Arts honors thesis, 73 p., accessed February 19, 2013, at http:/www.history.ukzn.ac.za/files/theses/paul rouillard.pdf.

Rudnick, R.L., and Gao, S., 2003, Composition of the continental crust, in Rudnick, R.L., ed., The crust, v. 3 of Holland, H.D., and Turekian, K.K., eds., Treatise on geochemistry: Oxford, United Kingdom, ElsevierPergamon, p. 1-64. [Also available at http://dx.doi.org/ 10.1016/B0-08-043751-6/03016-4.] 
Russian Platinum, 2011a, Artel Starateley "Amur": Moscow, Russia, Russian Platinum Web page, accessed March 8, 2013, at http://www.russian-platinum.ru/ our_business/kondyor_mine_as_amur.

Russian Platinum, 2011b, Chernogorskaya mining company: Moscow, Russia, Russian Platinum Web page, accessed March 8, 2013, at http://www.russian-platinum.ru/ our_business/chernogoskoye_deposit.

Sargeant, Fiona, 2001, The seismic stratigraphy of the Bushveld igneous complex, South Africa: Liverpool, England, University of Liverpool, Ph.D. dissertation, $425 \mathrm{p}$.

Sawkins, F.J., 1984, Metal deposits in relation to plate tectonics: Berlin, Germany, Springer-Verlag, 325 p.

Schissel, Don, Tsvetkov, A.A., Mitrofanov, F.P., and Korchagin, A.U., 2002, Basal platinum-group element mineralization in the Federov Pansky layered mafic intrusion, Kola Peninsula, Russia: Economic Geology, v. 97, p. 1657-1677. [Also available at http://dx.doi.org/10.2113/ gsecongeo.97.8.1657.]

Schmidt, J.M., and Rogers, R.K., 2007, Metallogeny of the Nikolai large igneous province (LIP) in southern Alaska and its influence on the mineral potential of the Talkeetna Mountains, in Ridgway, K.D., Trop, J.M., Glen, J.M.G., and O'Neill, J.M., eds., Tectonic growth of a collisional continental margin - Crustal evolution of southern Alaska: Geological Society of America Special Paper 431, p. 623-648. [Also available at http://dx.doi.org/10.1130/ 2007.2431(24).]

Schmidt, J.M., Light, T.D., Drew, L.J., Wilson, F.H., Miller, M.L., and Saltus, R.W., 2007, Undiscovered locatable mineral resources in the Bay Resource Management Plan Area, Alaska-A probabilistic assessment: U.S. Geological Survey Scientific Investigations Report 2007-5039, 50 p.

Schobbenhaus, Carlos, Gonçalves, J.H., Santos, J.O.S., Abram, M.B., Neto, R.L., Muniz de Matos, G.M., Vidotti, R.M., Ramos, M.A.B., and Alves de Jesus, J.D., 2004, Carta geológica do Brasil ao milionésimo-Systema de informações geográficas-SIG (edição 2004) [Geological map of Brazil, 1:1,000,000 scale, geographical information system - GIS (2004 edition)]: Brasília, Brazil, Companhia de Pesquisa de Recursos Mineirais, Serviço Geológico do Brasil, scale 1:1,000,000, CD-ROM. [Set of 41 CD-ROM disks, in Portuguese.]

Scoates, J.S., and Friedman, R.M., 2008, Precise age of the platiniferous Merensky Reef, Bushveld Complex, South Africa, by the U-Pb zircon chemical abrasion ID-TIMS technique: Economic Geology, v. 103, p. 465-471. [Also available at http://dx.doi.org/10.2113/gsecongeo.103.3.465.]
Scott, D.A., and Bray, Warwick, 1980, Ancient platinum technology in South America-Its use by the Indians in pre-Hispanic times: Platinum Metals Review, v. 24, no. 4, p. $147-157$.

Secher, K., Appel, P., and Nielsen, T.F.D., 2007, The PGE potential in Greenland: Geological Survey of Denmark and Greenland, Geology and Ore Bulletin, no. 8, February, 12 p. [Also available at http://extra.geus.info/geology_and_ore/ GO08_torsten.pdf.]

Segerstrom, Kenneth, and Carlson, R.R., 1982, Geologic map of the Banded upper zone of the Stillwater Complex and adjacent rocks, Stillwater, Sweet Grass, and Park Counties, Montana: U.S. Geological Survey Miscellaneous Investigation Series, Map I-1383, two sheets, scale 1:24,000. [Also available at http://pubs.er.usgs.gov/publication/i1383.]

Sharpe, M.R., 1981, The chronology of magma influxes to the eastern compartment of the Bushveld Complex as exemplified by its marginal border groups: Journal of the Geological Society of London, v. 138, no. 3, p. 307-326. [Also available at http://dx.doi.org/10.1144/ gsjgs.138.3.0307.]

Sharpe, M.R., and Hulbert, L.J., 1985, Ultramafic sills beneath the eastern Bushveld Complex-Mobilized suspensions of early lower zone cumulates in a parental magma with boninitic affinities: Economic Geology, v. 80, p. 849-871. [Also available at http://dx.doi.org/10.2113/ gsecongeo.80.4.849.]

Shcheka, G.G., Lehmann, Bernd, Gierth, Eike, Gömann, Karsten, and Wallianos, Alex, 2004, Macrocrystals of Pt-Fe alloy from the Kondyor PGE placer deposit, Khabarovskiy Kray, Russia-Trace element content, mineral inclusions and reaction assemblages: The Canadian Mineralogist, v. 42, no. 2, p. 601-617. [Also available at http://dx.doi.org/10.2113/gscanmin.42.2.601.]

Sherman, M.L., Malich, N.S., Mkrtichyan, A.K., and Strunin, B.M., eds., 1991, Geological map of the Norilsk ore district: Committee of Russian Federation on Geology and Use of Mineral Resources, State Geological Enterprise "Krasnoyarskgeologia" Geological Surveying Expedition, 1 map on 8 sheets, scale 1:200,000.

Shive, P.N., Houston, R.S., and Blakely, R.J., 1990, Modeling of aeromagnetic data from the Precambrian Lake Owens mafic complex, Wyoming: Geological Society of America Bulletin, v. 102, no. 9, p. 1317-1322. [Also available at http://dx.doi.org/10.1130/00167606(1990)102<1317:MOADFT>2.3.CO;2.]

Shmelev, V.R., and Filippova, S.S., 2010, Structure and formation mechanism of the Nizhny Tagil dunite-clinopyroxenite massif, central Urals: Geotectonics, v. 44, no. 4, p. 344-362. [Also available at http://dx.doi.org/10.1134/ S0016852110040047.] 
Singer, D.A., 1995, World-class base and precious metal deposits-A quantitative analysis: Economic Geology, v. 90, p. 88-104. [Also available at http://dx.doi.org/ 10.2113/gsecongeo.90.1.88.]

Singer, D.A., and DeYoung, J.H., Jr., 1980, What can grade tonnage relations really tell us?, in Guillemin, Claude, and Lagny, Phillipe, eds., Resources minérales-Mineral resources [in French and English]: Orléans, France, Mémoires Bureau de Recherches Géologique et Minières, no. 106 , p. 91-101.

Singer, D.A., Berger, V.I., and Moring, B.C., 2008, Porphyry copper deposits of the world-Database and grade and tonnage models, 2008 (version 1.0): U.S. Geological Survey Open-File Report 2008-1155, 45 p., accessed April 27, 2013, at http://pubs.usgs.gov/of/2008/1155/.

Song, Xie-Yan, Zhou, Mei-Fu, and Cao, Zhi-Min, 2004, Genetic relationships between base-metal sulfides and platinum-group minerals in the Yangliuping $\mathrm{Ni}-\mathrm{Cu}-(\mathrm{PGE})$ sulfide deposit, southwestern China: Canadian Mineralogist, v. 42, no. 2, April, p.469-483. [Also available at http://dx.doi.org/10.2113/gscanmin.42.2.469.]

Song, Xie-Yan, Zhou, Mei-Fu, Cao, Zhi-Min, Sun, Min, and Wang, Yun-Liang, 2003, Ni-Cu-(PGE) magmatic sulfide deposits in the Yangliuping area, Permian Emeishan igneous province, SW China: Mineralium Deposita, v. 38, p. 831-843. [Also available at http://dx.doi.org/10.1007/ s00126-003-0362-3.]

Sotnikov, V.I., Berzina, A.N., Economou-Eliopoulos, Maria, and Eliopoulos, D.G., 2001, Palladium, platinum and gold distribution in porphyry $\mathrm{Cu} \pm$ Mo deposits of Russia and Mongolia: Ore Geology Reviews, v. 18, nos. 1-2, p. 95-111. [Also available at http://dx.doi.org/10.1016/ S0169-1368(01)00018-X.]

Southworth, D.D., and Foley, J.Y., 1986, Lode platinum-group metals potential of the Goodnews Bay ultramafic complex, Alaska: U.S. Bureau of Mines Open-File Report 51-86, 82 p.

Spaggiari, C.V., Bodorkos, S., Barquero-Molina, M., Tyler, I.M., and Wingate, M.T.D., 2009, Interpreted bedrock geology of the south Yilgarn and central Albany-Fraser orogen, Western Australia: Geological Survey of Western Australia, Record, 2009/10, 84 p.

Stevens, H.J., 1905, The copper handbook-A manual of the copper industry of the world, vol. V, for the year 1904: Houghton, Mich., Horace J. Stevens, 882 p.

Storey, Michael, Duncan, R.A., and Tegner, Christian, 2007, Timing and duration of volcanism in the North Atlantic igneous province-Implications for geodynamics and links to the Iceland hotspot: Chemical Geology, v. 241, nos. 3-4, p. 264-281. [Also available at http://dx.doi.org/ 10.1016/j.chemgeo.2007.01.016.]
Suter, G.W., II, 1996, Toxicological benchmarks for screening contaminants of potential concern for effects on freshwater biota: Environmental Toxicology and Chemistry, v. 15 , no. 7, p. 1232-1241. [Also available at http://dx.doi.org/10.1002/etc.5620150731.]

Sutphin, D.M., and Page, N.J, 1986, International strategic minerals inventory summary report-Platinum-group metals: U.S. Geological Survey Circular 930-E, 34 p.

Szentpéteri, Krisztián, Watkinson, D.H., Molnar, Ferenc, and Jones, P.C., 2002, Platinum-group elements-Co-Ni-Fe sulfarsenides and mineral paragenesis in $\mathrm{Cu}-\mathrm{Ni}$-platinumgroup element deposits, Copper Cliff North area, Sudbury, Canada: Economic Geology, v. 97, p. 1459-1470. [Also available at $\mathrm{http} / / / \mathrm{dx}$.doi.org/10.2113/gsecongeo.97.7.1459.]

Talvivaara Mining Company plc, 2013, Operations-Mineral resources: Espoo, Finland, Talvivaara Mining Company plc, accessed April 8, 2013, at http://www.talvivaara.com/ operations/Mineral_resources.

Tarkian, M., and Koopmann, G., 1995, Platinum-group minerals in the Santo Tomas II (Philex) porphyry coppergold deposit, Luzon Island, Philippines: Mineralium Deposita, v. 30, no. 1, p. 39-47. [Also available at http://dx.doi.org/10.1007/BF00208875.]

Taylor, S.R., and McLennan, S.M., 1995, The geochemical evolution of the continental crust: Reviews of Geophysics, v. 33, no. 2, p. 241-265. [Also available at http://dx.doi.org/ 10.1029/95RG00262.]

Teluk, A.J., 2001, Fifield platinum project, NSW, AustraliaPlatinum metallogenesis, Ural-Alaskan type complexesTechnical report prepared for Rimfire Pacific Mining NL: Sydney, New South Wales, Australia, Geodyne Pty Ltd., November, 71 p., accessed March 28, 2013, at http://www.rimfire.com.au/PDF/Geodyne $\% 20$ report $\% 20$ complete $\% 20$ with $\% 20$ figs.pdf.

Tiax LLC, 2003, Platinum availability and economics for PEMFC commercialization-Report prepared for the U.S. Department of Energy: Cambridge, Mass., Tiax LLC, December, 101 p., accessed July 27, 2005, at http://www.eere.energy.gov/hydrogenandfuelcells/pdfs/ tiax_platinum.pdf.

Tolstykh, N.D., Foley, J.Y., Sidorov, E.G., and Laajoki, K.V.O., 2002, Composition of the platinum-group minerals in the Salmon River placer deposit, Goodnews Bay, Alaska: Canadian Mineralogist, v. 40, no. 2, p. 463-471. [Also available at http://dx.doi.org/10.2113/gscanmin.40.2.463.]

Tolstykh, N.D., Sidorov, E.G., and Kozlov, A.P., 2004, Platinum-group minerals in lode and placer deposits associated with the Ural-Alaskan-type Gal'moenan Complex, Koryak-Kamchatka platinum belt, Russia: Canadian Mineralogist, v. 42, no. 2, p. 619-630. [Also available at http://dx.doi.org/10.2113/gscanmin.42.2.619.] 
Traoré, Daouda, Beauvais, Anicet, Augé, Thierry, Parisot, J.C., Colin, Fabrice, and Cathelineau, Michel, 2008, Chemical and physical transfers in an ultramafic rock weathering profile-Part 2-Dissolution vs. accumulation of platinum group minerals: American Mineralogist, v. 93, no. 1, p. 31-38. [Also available at http://dx.doi.org/10.2138/am.2008.2606.]

U.S. Bureau of Mines, 1933-34, Mineral resources of the United States 1930-31: U.S. Bureau of Mines, variously paginated. [Also available via http://minerals.usgs.gov/ minerals/pubs/commodity/.]

U.S. Bureau of Mines, 1933-96, Minerals yearbook 1932-94: U.S. Bureau of Mines, variously paginated. [Also available via http://minerals.usgs.gov/minerals/ pubs/commodity/.]

U.S. Bureau of Mines and U.S. Geological Survey, 1947, Appendix - Mineral position of the United States, in Hearings before a subcommittee of the Committee on Public Lands, U.S. Senate, Eightieth Congress-First session on investigation of the factors affecting minerals, fuels, forestry, and reclamation projects-May 15, 16, and 20, 1947: Washington, D.C., U.S. Government Printing Office, p. 165-310.

U.S. Bureau of Mines and U.S. Geological Survey, 1980, Principles of a resource/reserve classification for minerals: U.S. Geological Survey Circular 831, 5 p. [Also available at http://pubs.usgs.gov/circ/1980/0831/report.pdf.]

U.S. Bureau of Mines, 1991, Mineral investigations on the Juneau Mining District, Alaska, 1984-1988: U.S. Bureau of Mines Special Publication, v. 1, Executive Summary, 49 p.

U.S. Congress, Office of Technology Assessment, 1985, Strategic materials-Technologies to reduce U.S. import vulnerability: Washington, D.C., U.S. Congress, Office of Technology Assessment, OTA-ITE-248, 409 p., accessed February 25, 2013, at http://www.princeton.edu/ ota/ disk2/1985/8525/852501.PDF.

U.S. Department of State, 2009, Small-scale digital international land boundaries (SSIB) — Lines, (10th ed.): Washginton, D.C., U.S. Department of State Boundaries and Sovereignty Encyclopedia.

U.S. Environmental Protection Agency, 2009, National recommended water quality criteria: U.S. Environmental Protection Agency Web page, accessed March 26, 2013, at http://www.epa.gov/waterscience/criteria/wqcriteria.html.

U.S. Geological Survey, 1996, Global 30 arc-second elevation (GTOPO30): Reston, Va., U.S. Geological Survey dataset (digital elevation model), accessed June 23, 2014, at https://ta.cr.usgs.gov/GTOPO30.

U.S. Geological Survey, 1997-2016, Minerals yearbook 1995-2012: U.S. Geological Survey, variously paged. [Also available at http://minerals.usgs.gov/minerals/pubs/ myb.html.]
U.S. Geological Survey National Mineral Resource Assessment Team, 2000, 1998 assessment of undiscovered deposits of gold, silver, copper, lead, and zinc in the United States: U.S. Geological Survey Circular 1178, 21 p. [A Portable Document (PDF) recompilation of USGS Open-File Report 96-96 and Circular 1178 was prepared by Paul Schruben and released as U.S. Geological Survey OpenFile Report 02-198 in 2002.] [Also available at http://pubs.usgs.gov/circ/c1178/c1178.pdf.]

United Nations Conference on Trade and Development Secretariat, 1995, Minerals and fuel price risks in southern Africa, and possibilities for risk management: United Nations Conference on Trade and Development, GE.95-53540, 47 p., accessed February 15, 2013, at http://unctad.org/en/Docs/pocomd69.en.pdf.

United Nations Conference on Trade and Development, [undated], Platinum-Economic policies: United Nations Conference on Trade and Development, accessed February 15, 2013, at http://r0.unctad.org/infocomm/ anglais/platinum/ecopolicies.htm.

Vale S.A., 2012, Form 20-F-2011: U.S. Securities and Exchange Commission, 231 p., accessed October 29, 2015, at http://www.sec.gov/Archives/edgar/data/917851/ 000104746911004222/a2202934z20-f.htm.

van der Merwe, M.J., 1976, The layered sequence of the Potgietersrus limb of the Bushveld Complex: Economic Geology, v. 71, p. 1327-1351. [Also available at http://dx.doi.org/10.2113/gsecongeo.71.7.1337.]

Vaughan, D.J., and Craig, J.R., 1978, Mineral chemistry of metal sulfides: Cambridge, United Kingdom, Cambridge University Press, 493 p.

Venter, A.D., Vakkari, Ville, Beukes, J.P., van Zyl, P.G., Laakso, Heikki, Mabaso, Desmond, Tiitta, Petri, Josipovic, Miroslav, Kulmala, Markku, Pienaar, J.J., and Laakso, Lauri, 2012, An air quality assessment in the industrialised western Bushveld igneous complex, South Africa: South African Journal of Science, v. 108, no. 9/10, 10 p. [Also available at http://dx.doi.org/10.4102/ sajs.v108i9/10.1059.]

Verbeek, Julian, and Lomberg, Ken, 2005, Rooipoort PGE, Mokopane, Limpopo Province, South Africa-Qualified persons report, prepared for Caledonia Mining Corp.: Perth, Western Australia, Australia, RSG Global Pty. Ltd., December, 56 p. plus 5 appendixes, accessed September 21, 2011, at http://www.caledoniamining.com/ pdfs/CALPres051221.pdf.

Vermaak, C.F., and von Gruenewaldt, G., 1986, Introduction to the Bushveld Complex, in Anhaeusser, C.R., and Maske, S., eds., Mineral deposits of southern Africa, v. 2: Johannesburg, South Africa, Geological Society of South Africa, p. 1021-1029. 
Viljoen, M.J., 1999, The nature and origin of the Merensky Reef of the western Bushveld Complex based on geological facies and geophysical data: South African Journal of Geology, v. 102, no. 3, p. 221-239.

Vogeli, J., Reid, D.L., Becker, M., Broadhurst, J., and Franzidis, J.-P., 2011, Investigation of the potential for mineral carbonation of PGM tailings in South Africa: Minerals Engineering, v. 24, no. 12, p. 1348-1356. [Also available at http://dx.doi.org/10.1016/j.mineng.2011.07.005.]

von Gruenewaldt, G., Behr, S.H., and Wilhelm, H.J., 1989, Some preliminary petrological investigations of the Molopo Farms Complex, Botswana, and its Ni-Cu sulphide mineralization, in Prendergast. M.D., and Jones M.J., eds., Magmatic sulphides-The Zimbabwe volume: London, United Kingdom, Institution of Mining and Metallurgy, p. $95-105$.

von Gruenewaldt, Gerhard, 1977, The mineral resources of the Bushveld Complex: Minerals Science and Engineering, v. 9 , no. 2, p. 83-95.

Wagner, P.A., 1929, The platinum deposits and mines of South Africa: London, United Kingdom, Oliver and Boyd, 326 p., 38 pls., 2 fold. profiles.

Wahl, J.J., Theron, P.D., and Maboeta, M.S., 2012, Soil mesofauna as bioindicators to assess environmental disturbance at a platinum mine in South Africa: Ecotoxicology and Environmental Safety, v. 86, no. 1, p. 250-260. [Also available at http://dx.doi.org/10.1016/j.ecoenv.2012.09.027.]

Walker, A.S.D., Key, R.M., Pouliquen, G., Gunn, G., Sharrock, J., McGeorge, I., Koketso, M., and Farr, J., 2010, Geophysical modelling of the Molopo Farms Complex in southern Botswana-Implications for its emplacement within the $\sim 2 \mathrm{Ga}$ large igneous provinces of southern and central Africa: South African Journal of Geology, v. 113, no. 4, p. 381-400. [Also available at http://dx.doi.org/10.2113/ gssajg.113.4.381.]

Walraven, F., 1986, A note on the stratigraphic terminology of the Bushveld Complex, in Anhaeusser, C.R., and Maske, S., eds., Mineral deposits of southern Africa, v. 2: Johannesburg, Geological Society of South Africa, p. 1039-1040.

Wasson, J.T., Xinwei, Ouyang, Wang, Jianmin, and Jerde, Eric, 1989, Chemical classification of iron meteorites-XI-Multi-element studies of 38 new irons and the high abundance of ungrouped irons from Antarctica: Geochimica et Cosmochimica Acta, v. 53, no. 3, p. 735-744. [Also available at http://dx.doi.org/10.1016/0016-7037(89)90016-1.]
Weatherstone, Niall, 2008, International standards for reporting of mineral resources and reserves-Status, outlook, and important issues: World Mining Congress \& Expo 2008, Krakow, Poland, September 9-12, 2008, presentation, 10 p., accessed December 26, 2011, at http://www.crirsco.com/ isr_mineral_resources_reserves0908.pdf.

Webb, S.J., Cawthorn, R.G., Nguuri, Teresia, and James, David, 2004, Gravity modeling of Bushveld Complex connectivity supported by southern Africa seismic experiment results: South African Journal of Geology, v. 107, nos. 1-2, p. 207-218. [Also available at http://dx.doi.org/10.2113/107.1-2.207.]

Western Mining Corp., 2005, Form 6-K-Report of foreign issuer-WMC Resources Ltd. [filing date January 7, 2005]: Securities and Exchange Commission, accessed September 21, 2015, at http://www.sec.gov/Archives/ edgar/data/1208222/000119312505002708/d6k.htm.

Wilburn, D.R., 2012, Global exploration and production capacity for platinum-group metals from 1995 through 2015: U.S. Geological Survey Scientific Investigations Report 2012-5164, 26 p. [Also available at http://pubs.usgs.gov/sir/2012/5164/.]

Wilburn, D.R., and Bleiwas, D.I., 2004, Platinum-group metals-World supply and demand: U.S. Geological Survey Open-File Report 2004-1224, 152 p. [Also available at http://pubs.usgs.gov/of/2004/1224/2004-1224.pdf.]

Wilde, Andy, 2005, Descriptive ore deposit models - Hydrothermal \& supergene Pt \& Pd deposits, in Mungall, J.E., ed., Exploration for platinum-group element deposits: Mineralogical Association of Canada Short Course Series, v. 35, p. 145-161.

Wilde, Andy, Edwards, Alaster, and Yakubchuk, Alexander, 2003, Unconventional deposits of Pt and Pd-A review with implications for exploration: SEG Newsletter, no. 52, p. $1,10-18$.

Wilhelm, H.J., Zhang, H., Chen, F.L., Elsenbroek, J.H., Lombard, M., and de Bruin, D., 1997, Geochemical exploration for platinum-group elements in the Bushveld Complex, South Africa: Mineralium Deposita, v. 32, no. 4, p. 349-361. [Also available at http://dx.doi.org/10.1007/ s001260050101.]

Wilson, A.H., 1996, The Great Dyke of Zimbabwe, in Cawthorn, R.G., ed., Layered intrusions: Amsterdam, Netherlands, Elsevier Science B.V., v. 15, p. 365-402. [Also available at http://dx.doi.org/10.1016/S01672894(96)80013-3.]

Wilson, A.H., and Prendergast, M.D., 1989, The Great Dyke of Zimbabwe - Guidebook for the pre-conference symposium excursion, 8th International Platinum Symposium: Harare, Zimbabwe, Geological Society of Zimbabwe, 46 p. 
Wilson, A.H., and Prendergast, M.D., 2001, Platinum-group element mineralisation in the Great Dyke, Zimbabwe, and its relationship to magma evolution and magma chamber structure: South African Journal of Geology, v. 104, no. 4, p. 319-342. [Also available at http://dx.doi.org/10.2113/ 104.4.319.]

Wilson, A.H., and Tredoux, M., 1990, Lateral and vertical distribution of platinum-group elements and petrogenetic controls on the sulfide mineralization in the P1 pyroxenite layer of the Darwendale subchamber of the Great Dyke, Zimbabwe: Economic Geology, v. 85, p. 556-584. [Also available at http://dx.doi.org/10.2113/gsecongeo.85.3.556.]

Wilson, Allan, and Chunnett, Gordon, 2006, Trace element and platinum group element distributions and the genesis of the Merensky Reef, Western Bushveld Complex, South Africa: Journal of Petrology, v. 47, no. 12, p. 2369-2403. [Also available at http://dx.doi.org/10.1093/petrology/eg1048.]

Wiseman, C.L.S., and Zereini, F., 2009, Airborne particulate matter, platinum group elements and human health-A review of recent evidence: Science of the Total Environment, v. 407, no. 8, p. 2493-2500. [Also available at http://dx.doi.org/ 10.1016/j.scitotenv.2008.12.057.]

Wood, S.A., 1991, Experimental determination of the hydrolysis constants of $\mathrm{Pt}^{2+}$ and $\mathrm{Pd}^{2+}$ at $25^{\circ} \mathrm{C}$ from the solubility of $\mathrm{Pt}$ and $\mathrm{Pd}$ in aqueous hydroxide solutions: Geochimica et Cosmochimica Acta, v. 55, no. 7, p. 1759-1767. [Also available at http://dx.doi.org/ 10.1016/0016-7037(91)90021-V.

Wood, S.A., 2002, The aqueous geochemistry of the platinumgroup elements with applications to ore deposits, in Cabri, L.J., ed., Geology, geochemistry, mineralogy and mineral beneficiation of platinum-group elements: Montreal, Quebec, Canada, Canadian Institute of Mining. Metallurgy and Petroleum Special Volume 54, p. 211-249.

Wood, S.A., Mountain B.W., and Pan, Pujing, 1992, The aqueous geochemistry of platinum, palladium and goldRecent experimental constraints and a re-evaluation of theoretical predictions: The Canadian Mineralogist, v. 30, no. 4, p. $955-982$.

World Health Organization, 2008, Guidelines for drinkingwater quality-Volume 1 -Recommendations ( $3 \mathrm{~d}$ ed., incorporating first and second addenda): Geneva,

Switzerland, World Health Organization, 668 p., accessed April 4, 2014, at http://www.who.int/water_sanitation_health/ dwq/gdwq3rev/en/index.html.

Worst, B.G., 1957, Geological map of the Great Dyke of southern Rhodesia: Southern Rhodesia Geological Survey, maps to accompany Geological Survey Bulletin No. 47, 1 map on 9 sheets, scale 1:100,000.
Xstrata plc, 2007, Xstrata Nickel-Update on Kabanga JV, Tanzania: Xstrata plc news release, February 15, 3 p., accessed March 11, 2013, at http://www.xstrata.com/ media/news/2007/02/15/0700CET/.

Xue, Ting, Sun, Xiaoming, He, Gaowen, Wang, Shengwei, Lu, Hongfeng, and Zhang, Mei, 2005, Geochemistry of $\mathrm{PGE}$ and $\mathrm{Au}$ in ferromanganese crusts from seamounts in the west Pacific Ocean, in Jingwen, Mao, and Bierlein, F.P., eds., Mineral deposit research-Meeting the global challenge-Proceedings of the eighth biennial SGA meeting, Beijing, China, August 18-21, 2005: Berlin, Germany, Springer-Verlag, p. 207-209.

Yager, T.R., Soto-Viruet, Yadira, and Barry, J.J., 2012, Recent strikes in South Africa's platinum-group metal mines -Effects upon world platinum-group metal supplies: U.S. Geological Survey Open-File Report 2012-1273, 18 p. [Also available at http://pubs.usgs.gov/of/2012/1273.]

Yao, Y., Viljoen, M.J., Viljoen, R.P., Wilson, A.H., Zhong, H., Liu., B.G., Ying, H.L., Tu, G.Z., and Luo, Y.N., 2001, Geological characteristics of PGE-bearing layered intrusions in southwest Sichuan Province, China: Johannesburg, South Africa, University of the Witwatersrand Information Circular no. 358, December, 17 p., accessed October 6, 2016, at https://www.wits.ac.za/media/ migration/files/358.pdf.

Yonglin, $\mathrm{Li}, 2005$, Prospects and opportunities for the development of Chinese nickel and cobalt industry: Jinchuan Group Co., Ltd. presentation, 30 p., accessed October 6, 2016, at http://web.archive.org/web/20110525012358/http:// www.jnmc.com/publication/meeting/zgngfzqjhjy.pdf.

Yumul, G.P., Jr., 2001, The Acoje block platiniferous dunite horizon, Zambales ophiolite complex, PhilippinesMelt type and associated geochemical controls: Resource Geology, v. 51, no. 2, p. 165-174. [Also available at http://dx.doi.org/10.1111/j.1751-3928.2001.tb00089.x.]

Zarubezhtsvetmet Austrasia Pty Ltd., 2009, Lukkulaisvaara platinum group metal field-Expert conclusion and recommendations: Zarubezhtsvetmet Austrasia Pty Ltd., 32 p., accessed March 20, 2013, at http://www.norit-platinum.ru/ Investors/Report_Pt_v\%203.doc.

Zientek, M.L., 1993, Mineral resource appraisal for locatable minerals-The Stillwater Complex, chap F of Hammarstrom, J.M., Zientek, M.L., and Elliott, J.E., eds., Mineral resource assessment of the Absaroka-Beartooth study area, Custer and Gallatin National Forests, Montana: U.S. Geological Survey Open-File Report 93-207, p. F1-F83. [Also available at http://pubs.usgs.gov/ of/1993/0207/report.pdf.] 
Zientek, M.L., Causey, J.D., Parks, H.L., and Miller, R.J., 2014, Platinum-group elements in southern Africa-Mineral inventory and an assessment of undiscovered mineral resources: U.S. Geological Survey Scientific Investigations Report 2010-5090-Q, 126 p. plus GIS data. [Also available at http://dx.doi.org/10.3133/sir20105090Q.]

Zientek, M.L., Cooper, R.W., Corson, S.R., and Geraghty, E.P., 2002, Platinum-group element mineralization in the Stillwater Complex, Montana, in Cabri, L.J., ed., The geology, geochemistry, mineralogy and mineral beneficiation of platinum-group elements: Montreal, Quebec, Canada, Canadian Institute of Mining, Metallurgy, and Petroleum Special Volume 54, p. 459-481.

Zientek, M.L., Corson, S.R., and West, R.D., 2005, Geochemical surveys of soil and talus fines and the discovery of the J-M Reef, Stillwater Complex, Montana, in Mungall, J.E., ed., Exploration for platinum-group element deposits: Mineralogical Association of Canada Short Course Series v. 35, p. 391-407.
Zientek, M.L., Likhachev, A.P., Kunilov, V.E., Barnes, S.-J., Meier, A.L., Carlson, R.R., Briggs, P.H., Fries, T.L., and Adrian, B.M., 1994, Cumulus processes and the composition of magmatic ore deposits - Examples from the Talnakh District, Russia, in Lightfoot, P.C., and Naldrett, A.J., eds., Proceedings of the Sudbury-Noril'sk symposium: Sudbury Ontario, Canada, Ontario Geological Survey Special Volume 5, p. 373-392.

Zonenshain, L.P., Mezhelovsky, N.V., and Natapov, L.M., eds., 1988, Geodynamic map of the USSR and adjacent seas: Ministry of Geology of the USSR, Industrial Geological Objedinenie for Regional Studies of the USSR Territory (AEROGEOLOGIA), 1 map on 17 sheets, scale 1:2,500,000. [In Russian with English title.] 



\section{Tables N2, N5, N6, and N8-N10}




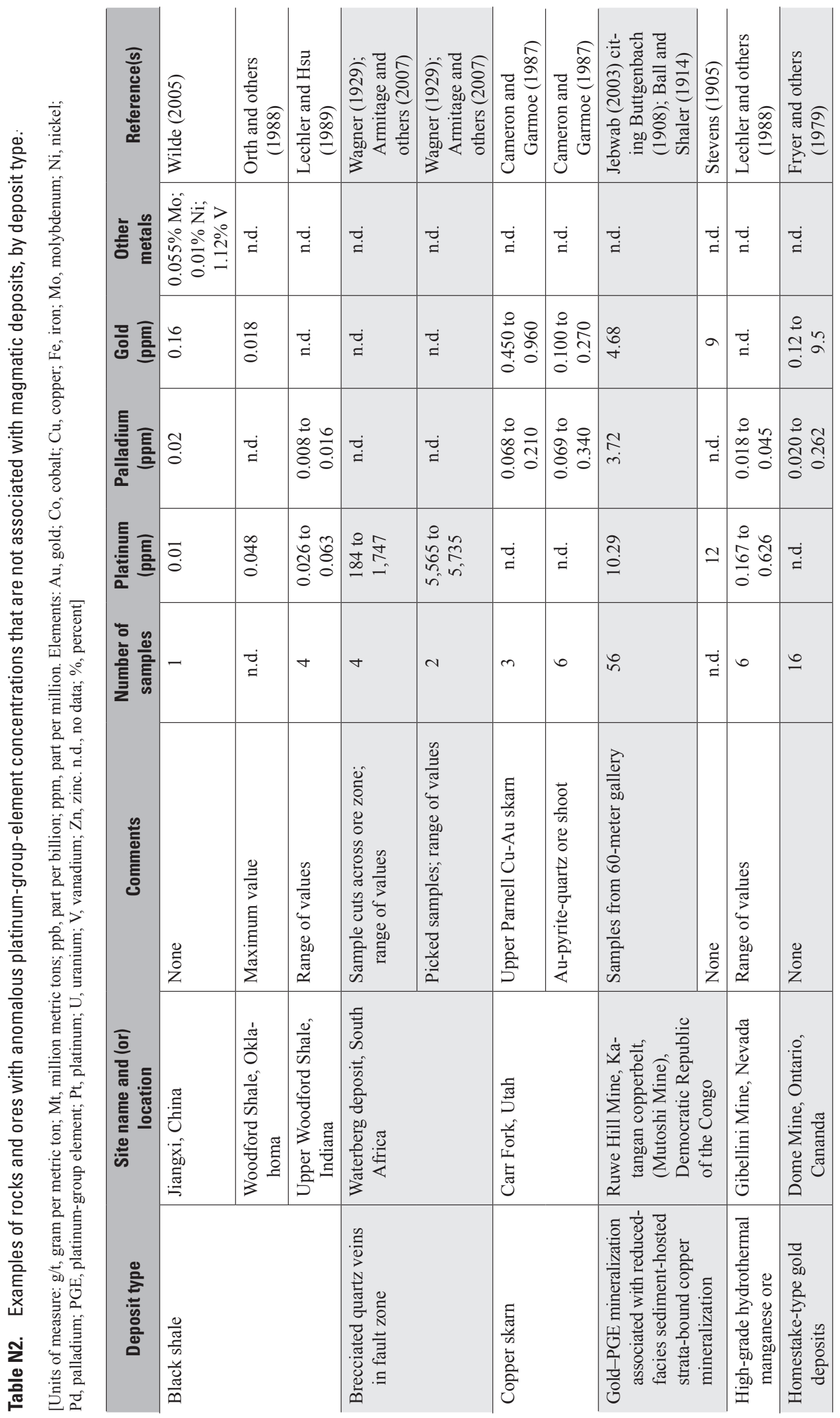




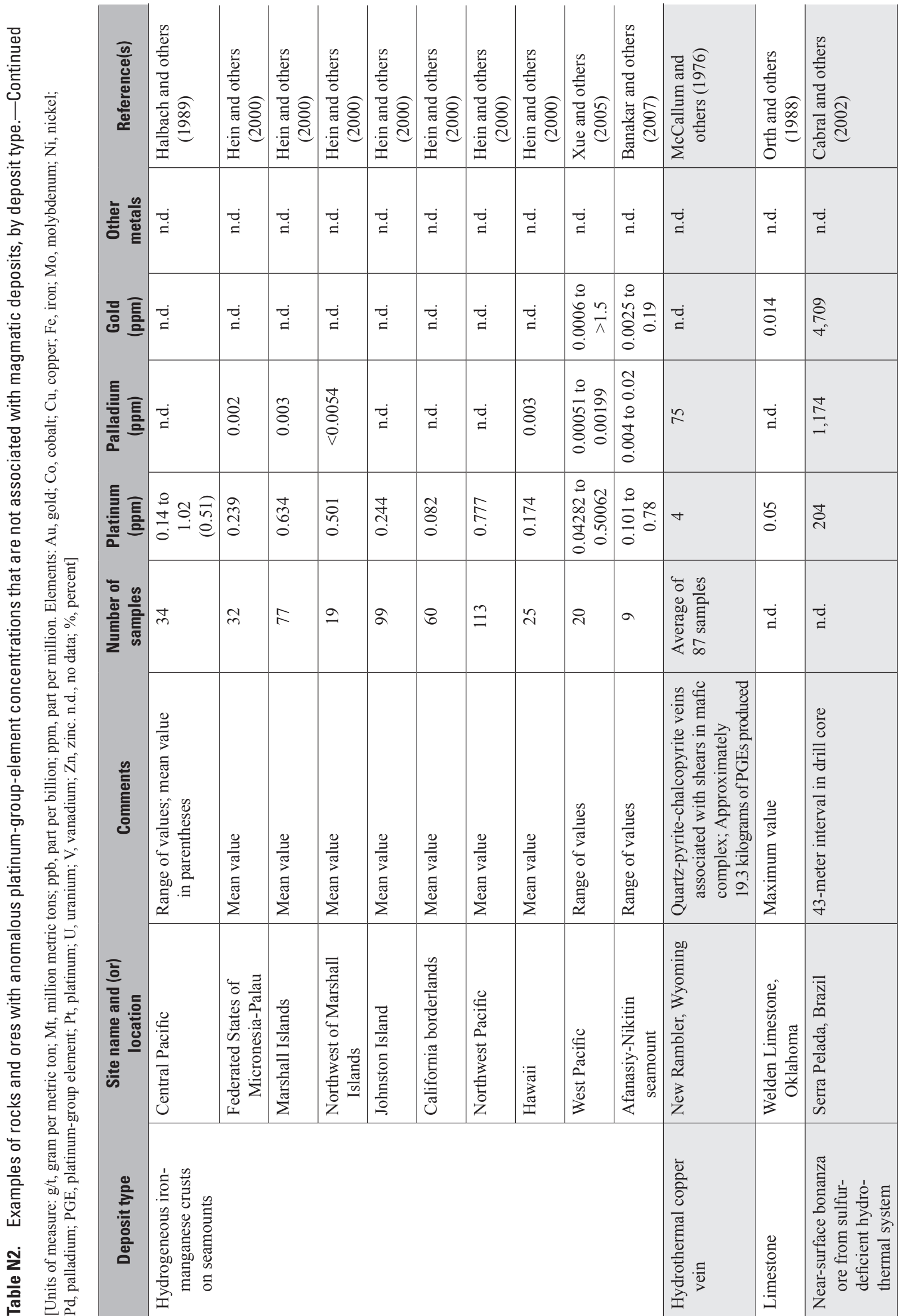



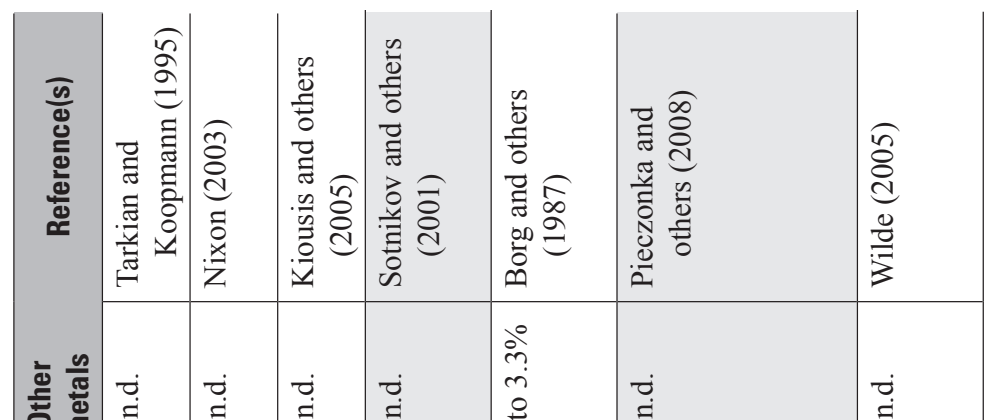

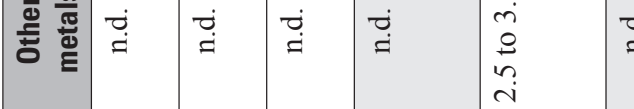

\begin{tabular}{|c|c|c|c|c|c|c|}
\hline 등 言 $\stackrel{\infty}{-}$ & 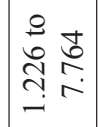 & ت্] & $\begin{array}{ll}\frac{0}{2} & \overline{0} \\
\frac{1}{0} & 0 \\
0 & 0 \\
0 & 0\end{array}$ & $\begin{array}{ll}0 & 0 \\
0 & 0 \\
0 & 0 \\
0 & 0 \\
0 & 0\end{array}$ & 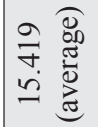 & $\begin{array}{l}0 \\
\qquad \\
\infty \\
\infty \\
\infty\end{array}$ \\
\hline
\end{tabular}

\begin{tabular}{|c|c|c|c|c|c|c|}
\hline 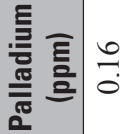 & 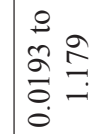 & ô & $\begin{array}{l}\stackrel{0}{0} \\
\stackrel{m}{0} \\
0 \\
0 \\
0\end{array}$ & $\begin{array}{ll}0 & \infty \\
0 & 8 \\
0 & 0\end{array}$ & 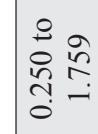 & ठै \\
\hline
\end{tabular}

\begin{tabular}{|c|c|c|c|c|c|}
\hline 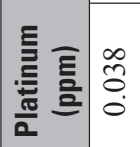 & 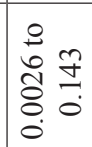 & $\frac{0}{0}$ & 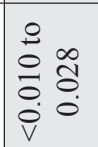 & 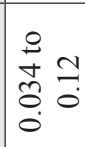 & $\begin{array}{ll}0 & \\
0 & \frac{1}{0} \\
\frac{0}{0} & 0\end{array}$ \\
\hline
\end{tabular}

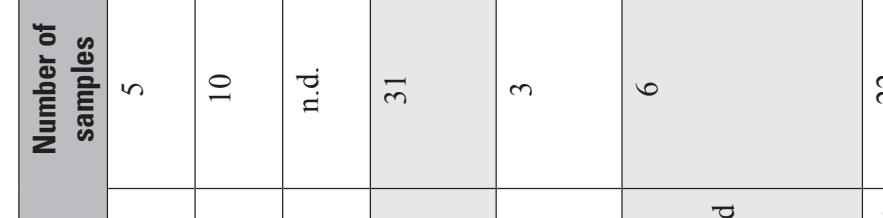

產

E्ञ

हี่ํ.:

离

镸

ही.

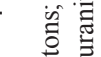

D

䙵 竞

言寻

雍

立

范

总

는

o

穿

$y$

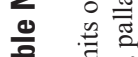

चै

|

चే

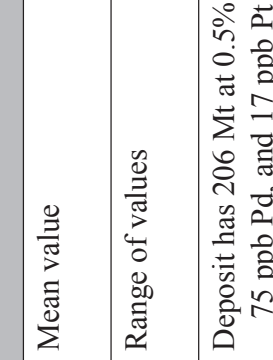

年

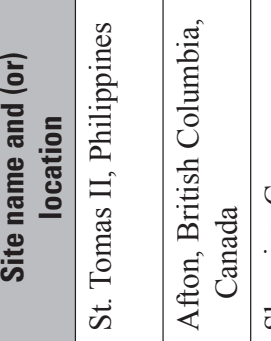

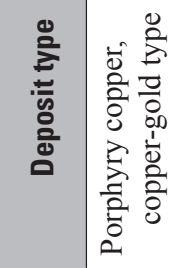
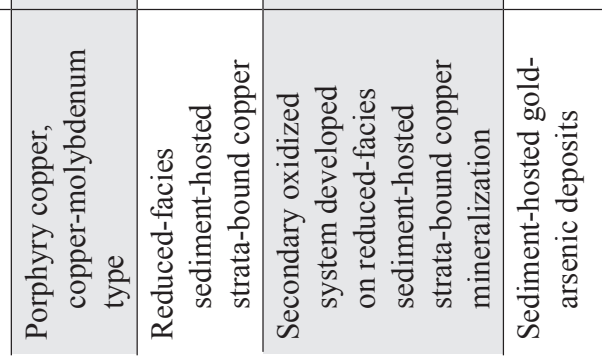

$\ddot{0}$

ส

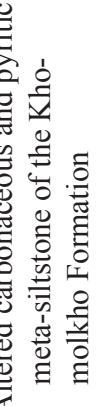

$\simeq$

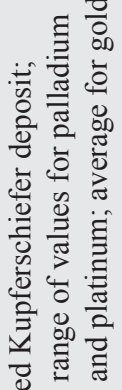

$\gtrless$

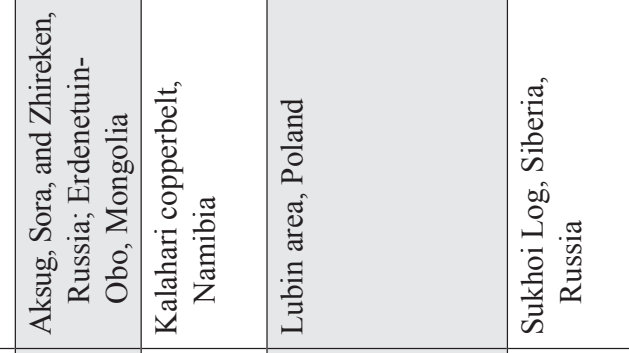




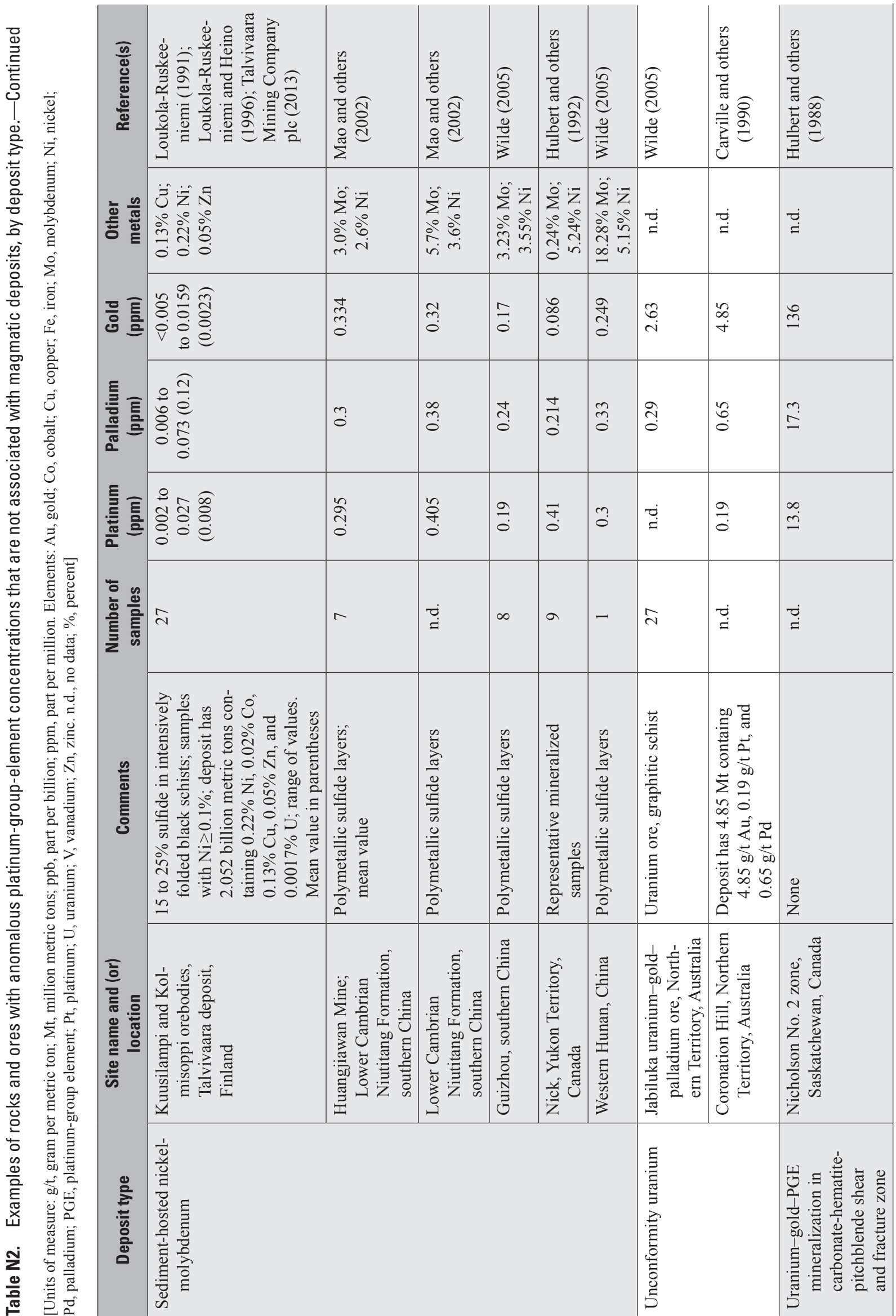




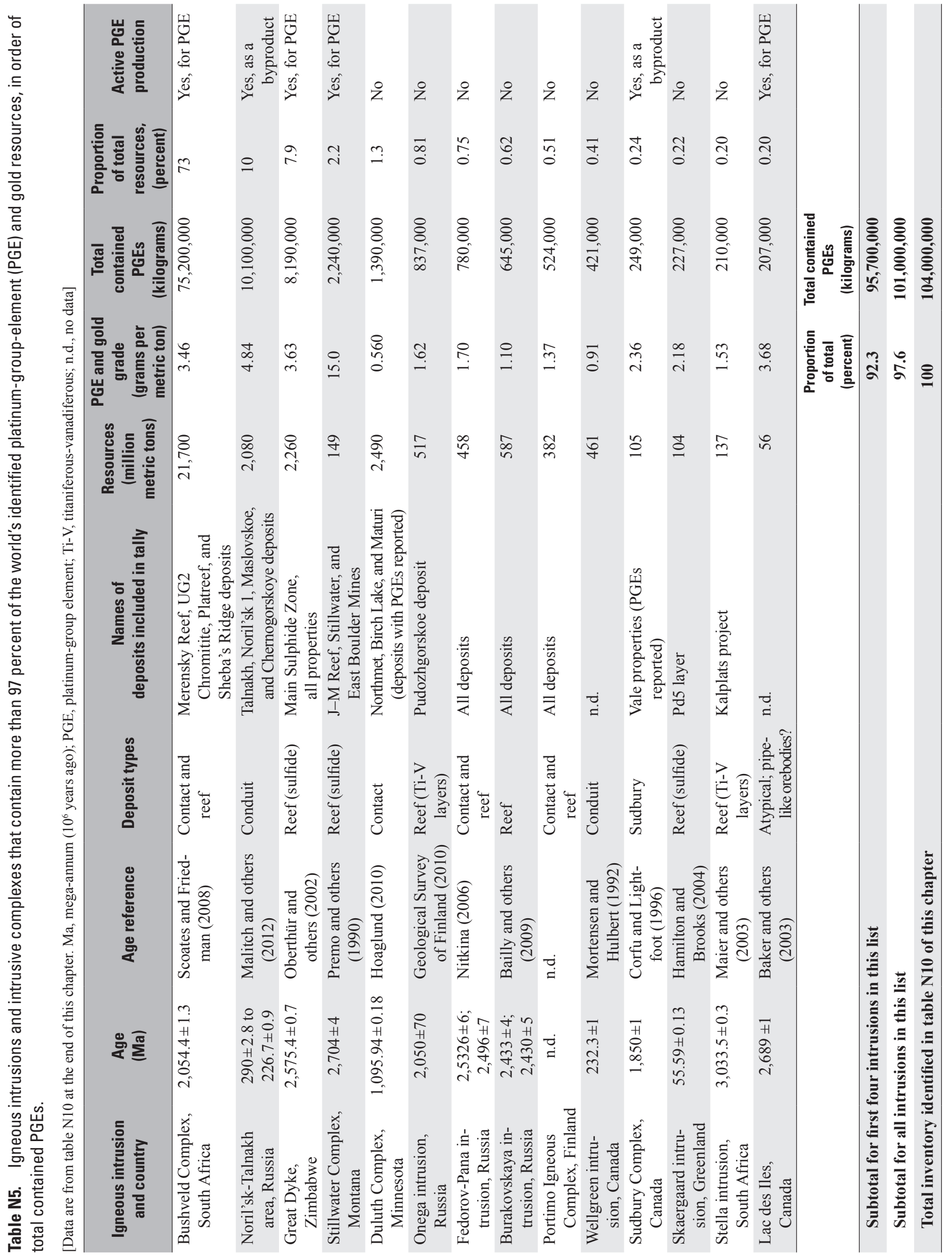


Table N6

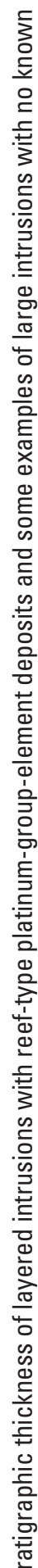

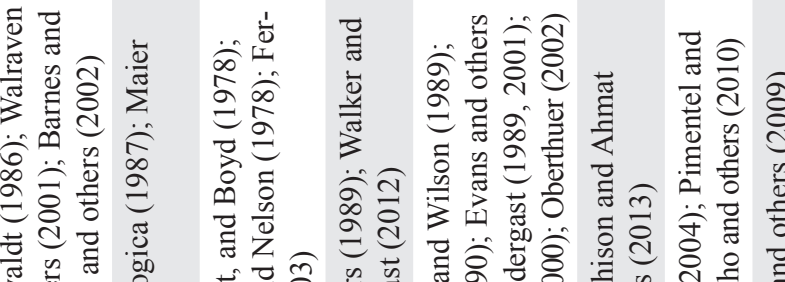

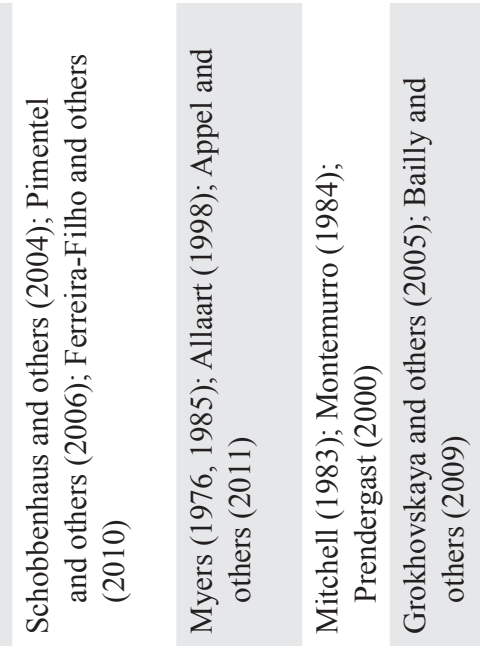

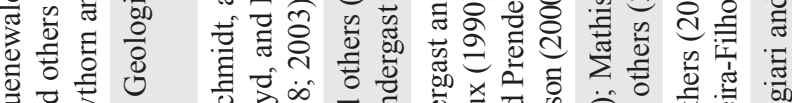

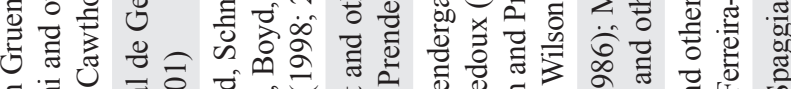

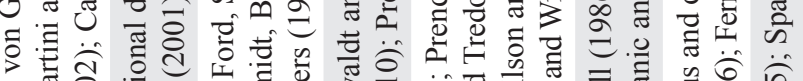

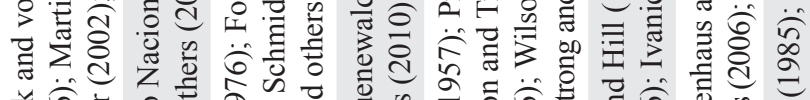

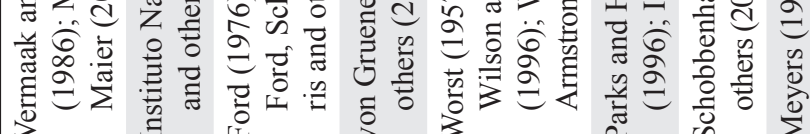

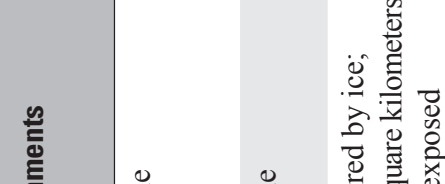

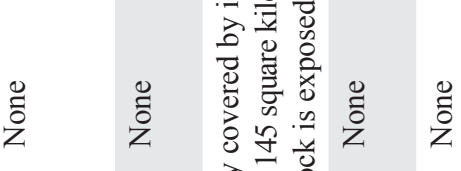

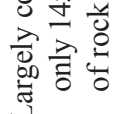
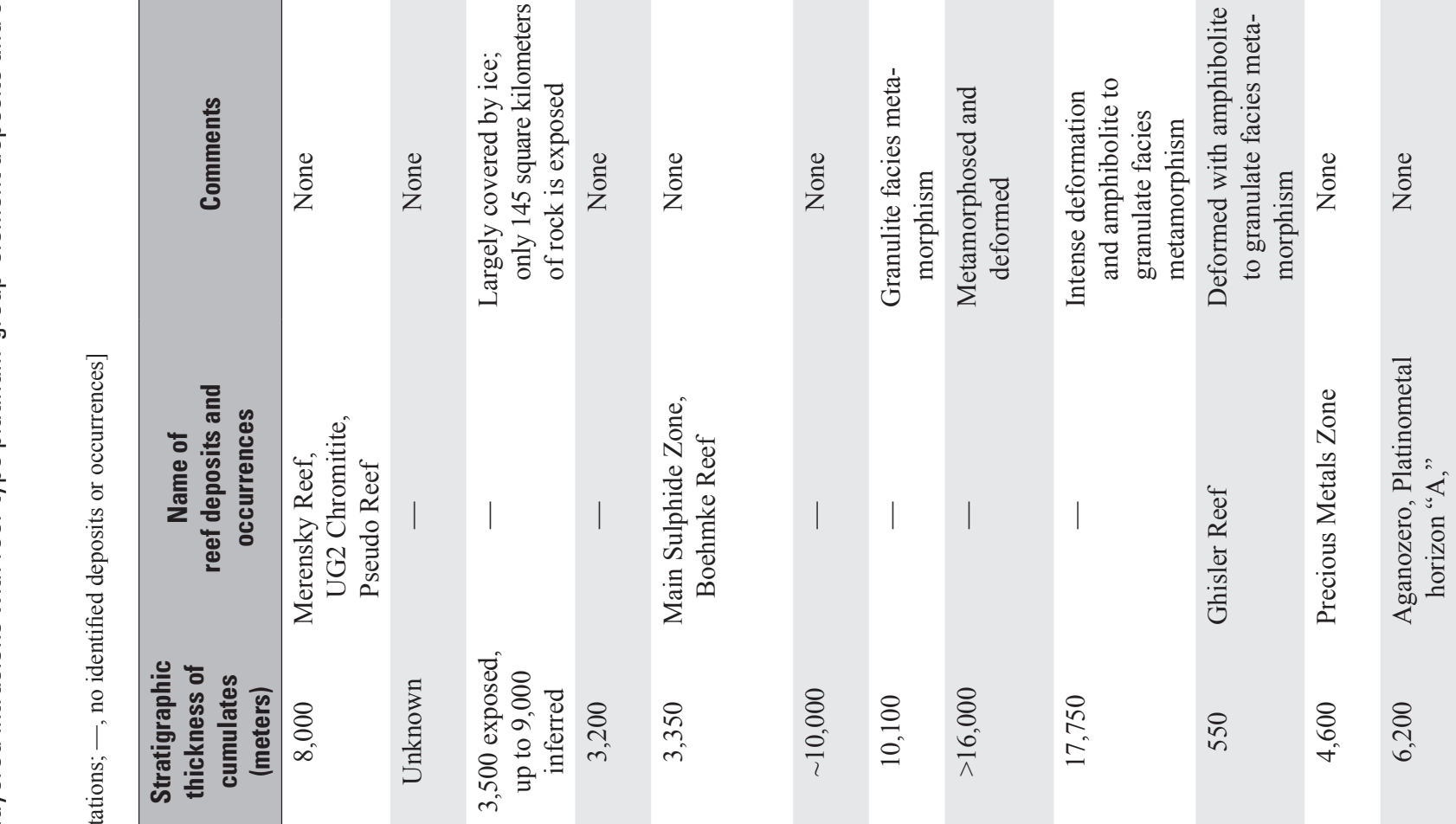

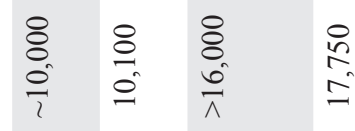
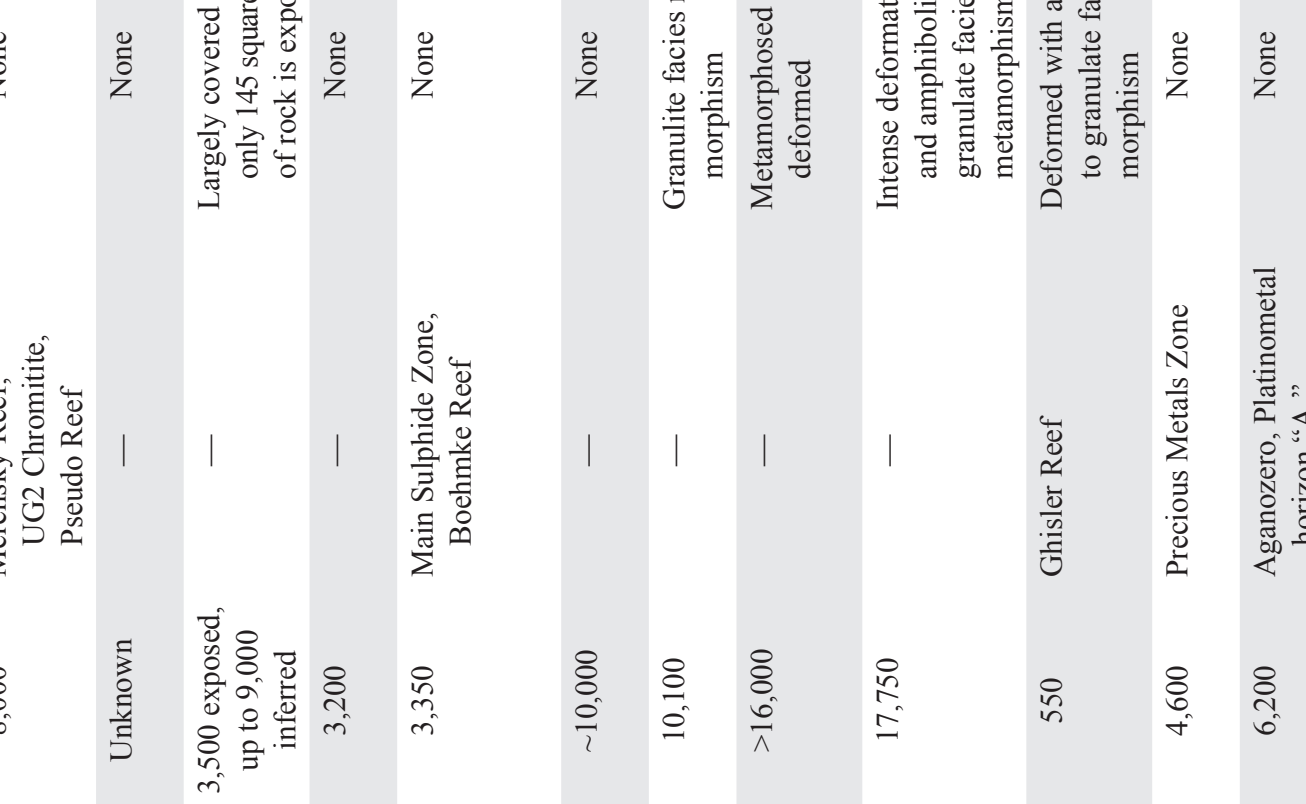

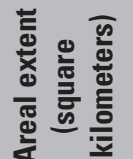

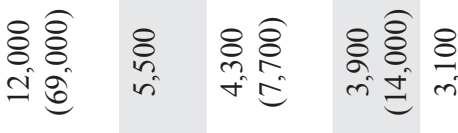

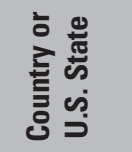
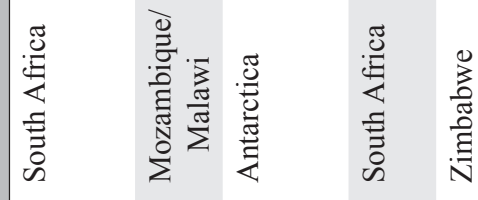

$\begin{array}{lll}8 & 8 & 8 \\ i & 8 & 0 \\ i & i & -1\end{array}$

$\stackrel{8}{i}$

융 웅 웅

竞

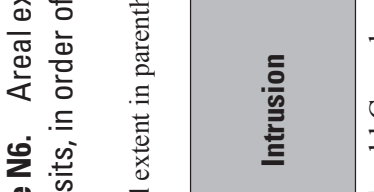
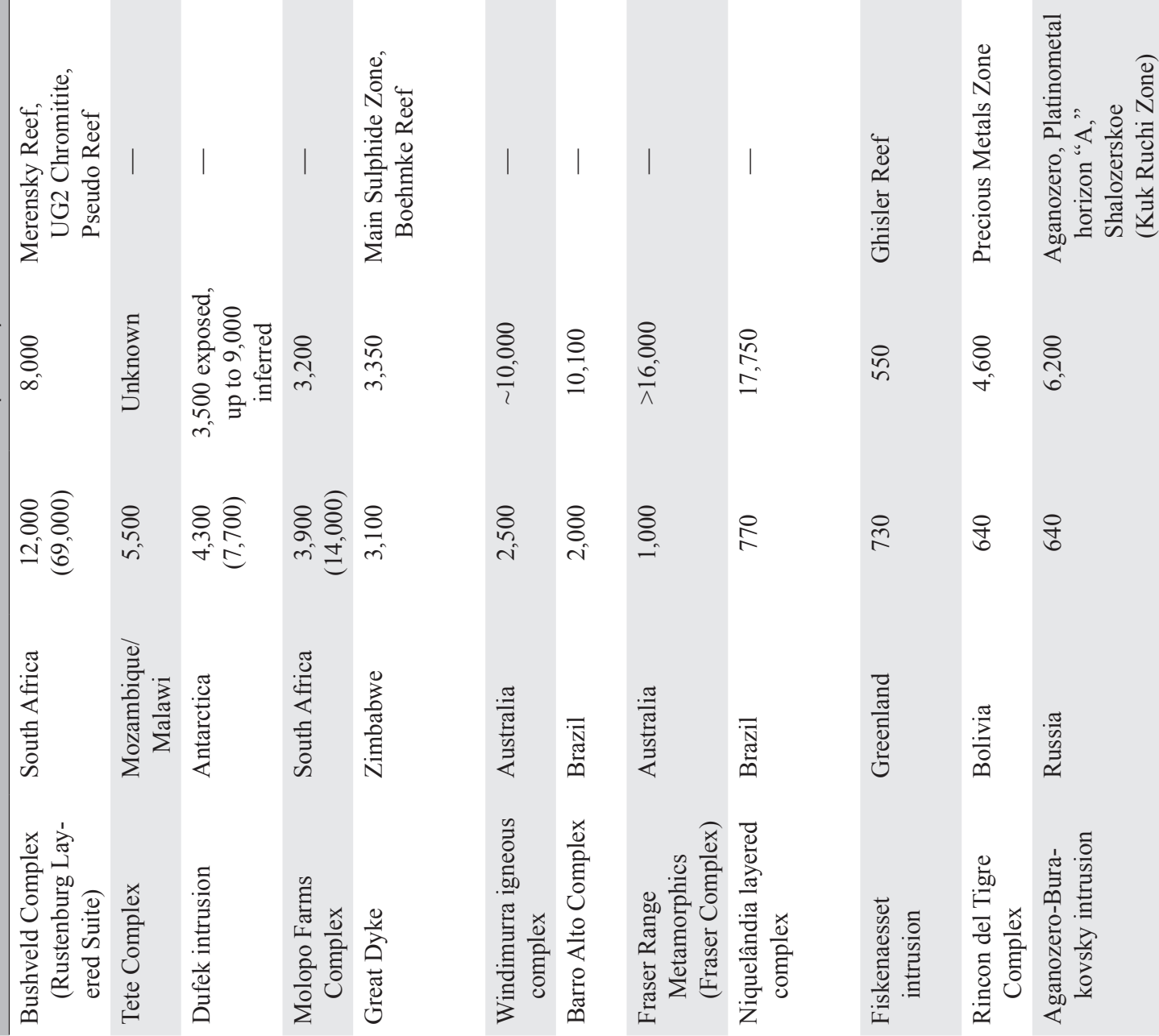

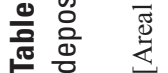
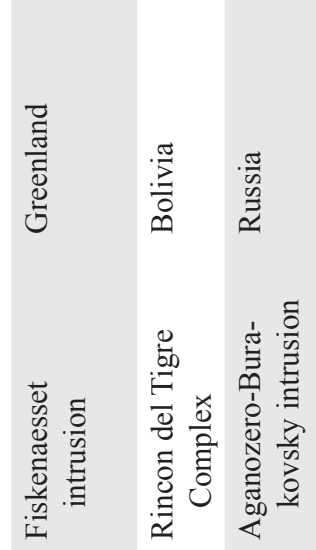


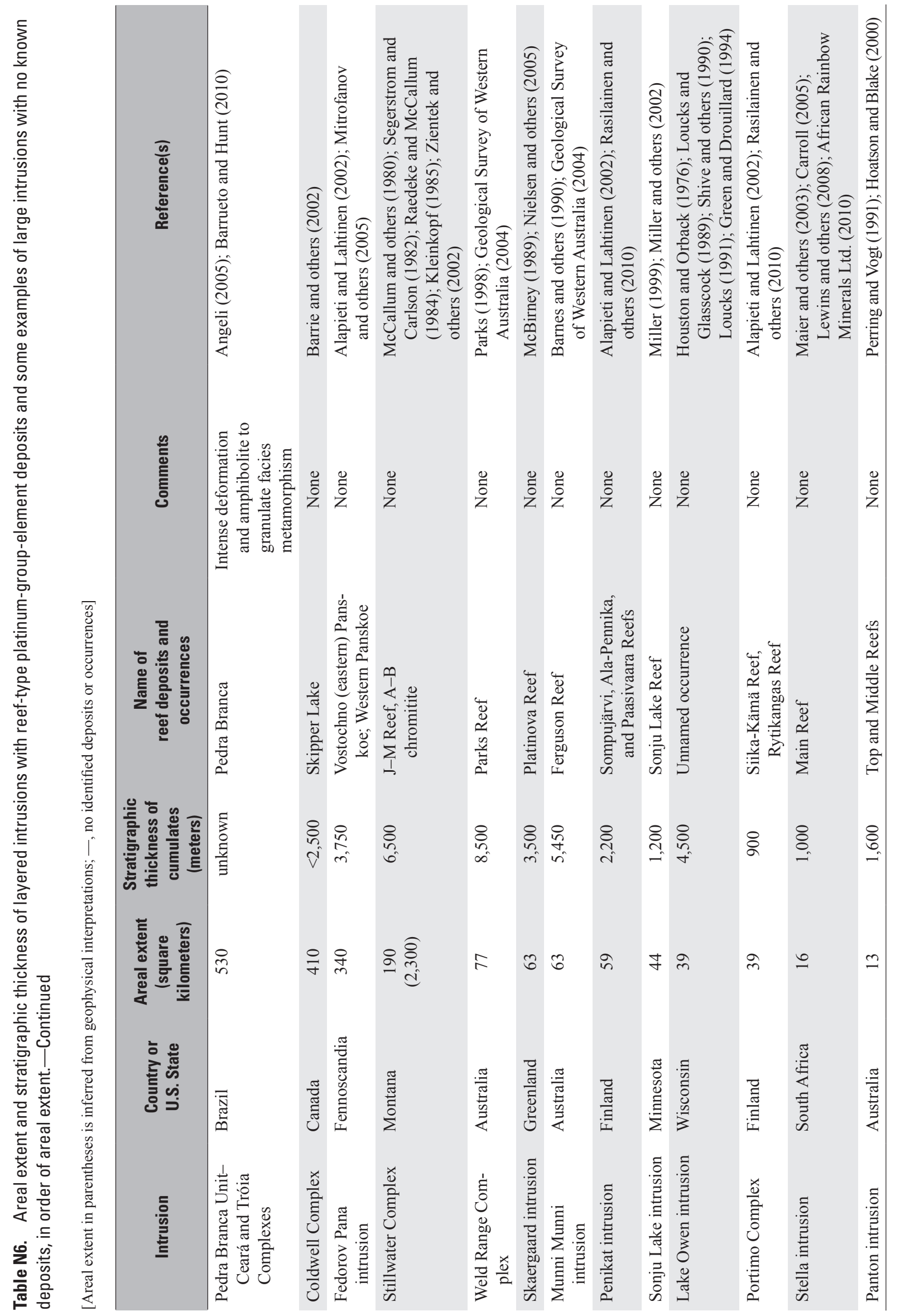




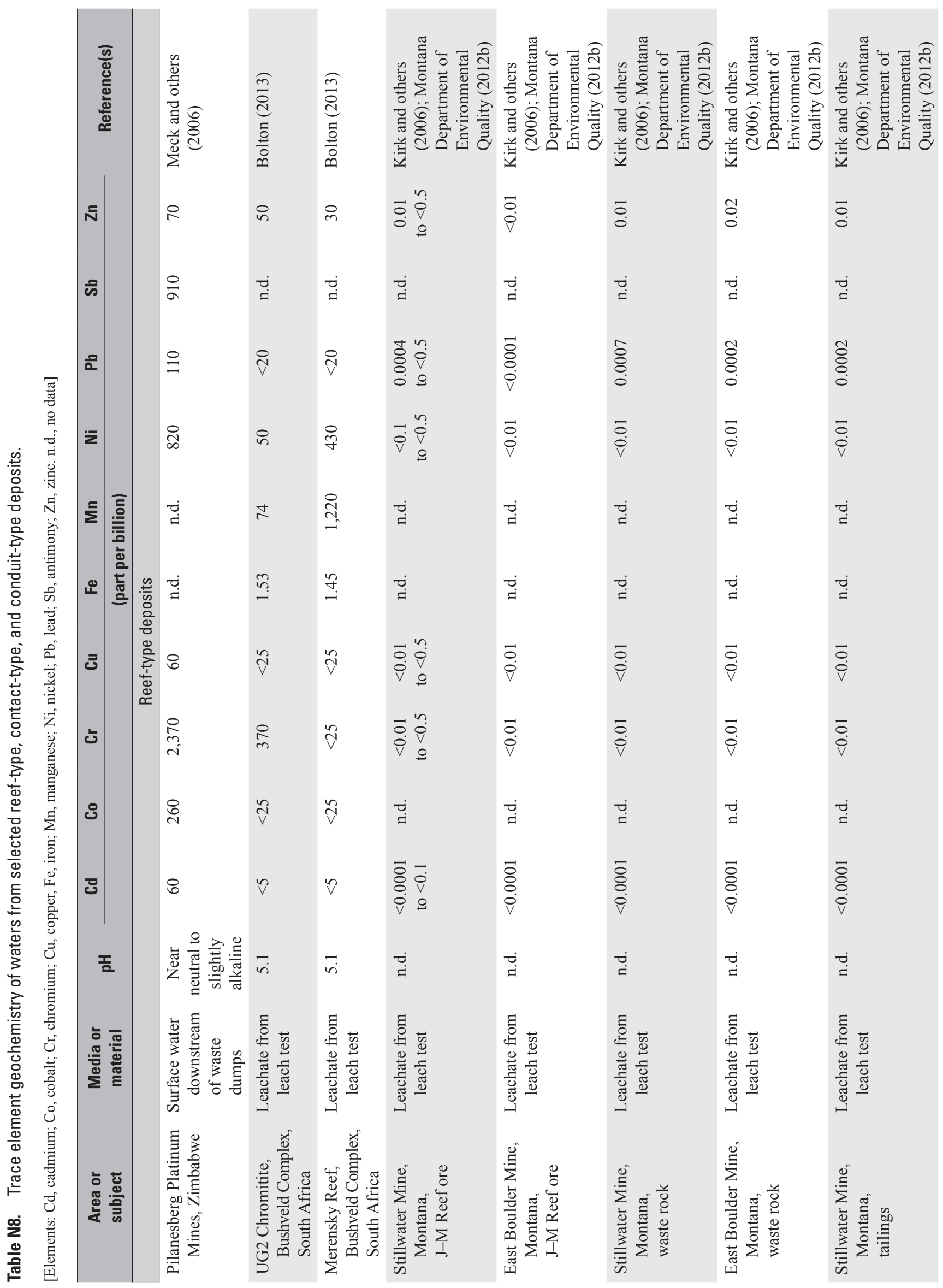




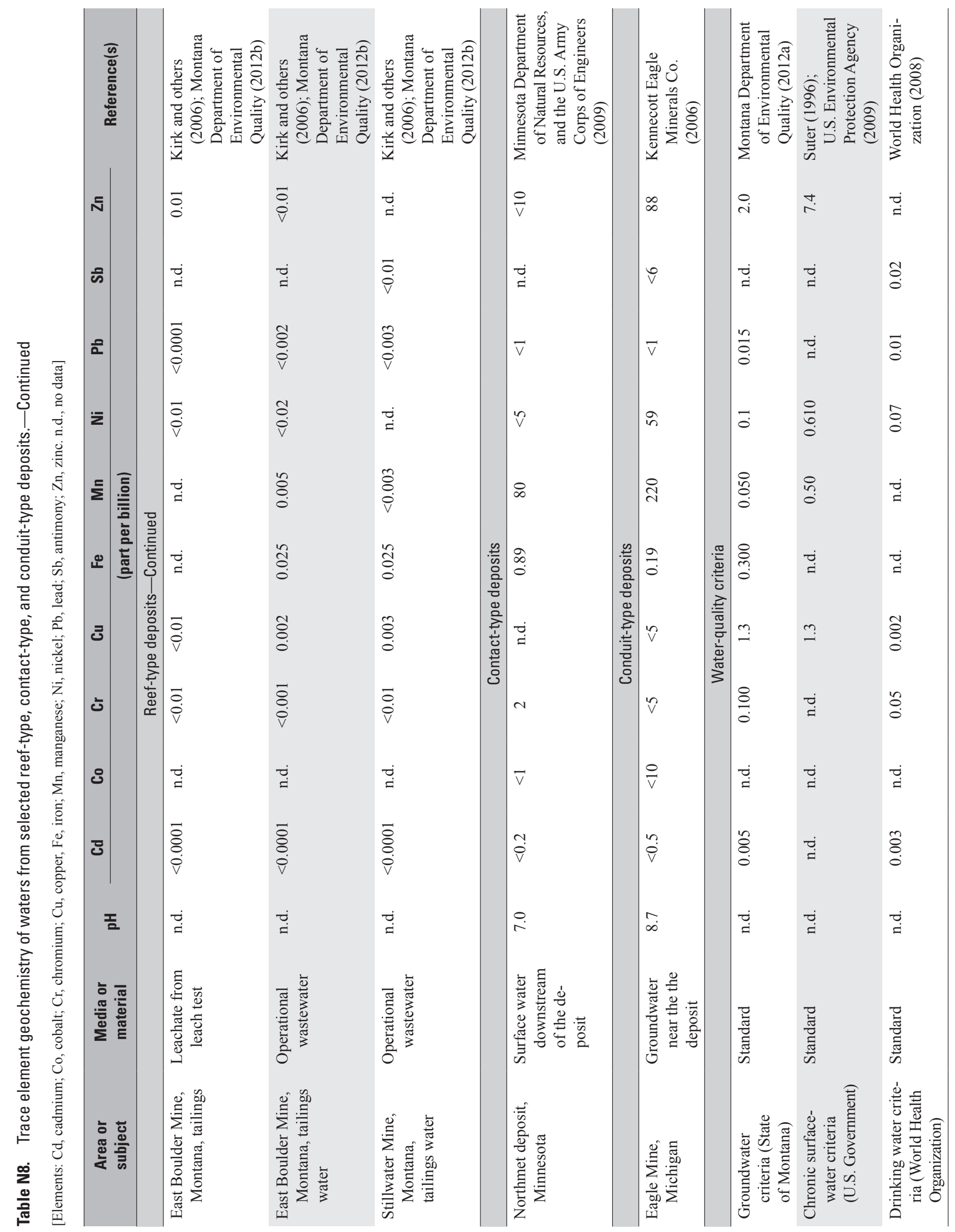




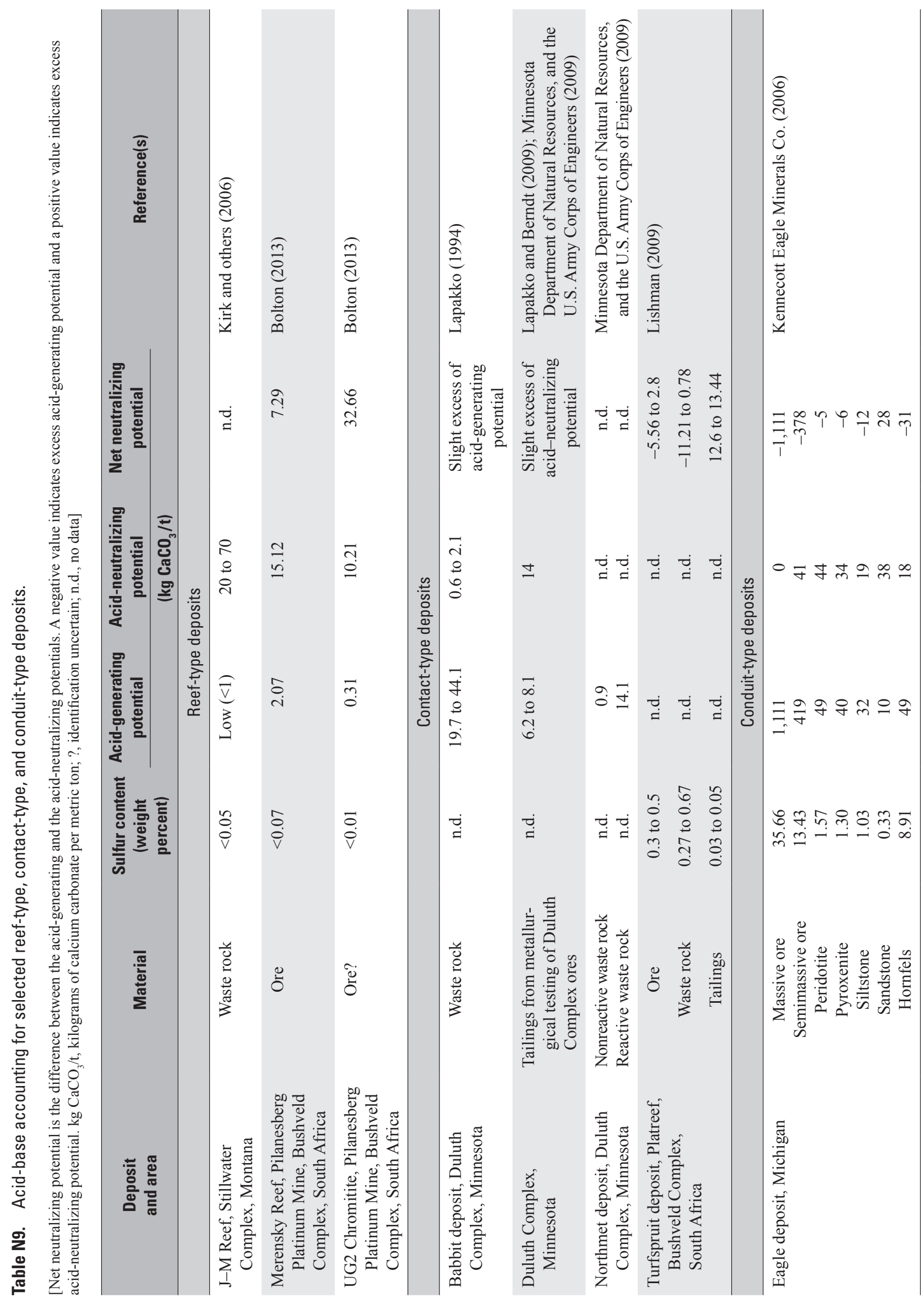




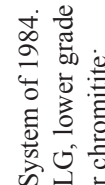

焉总

造产

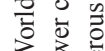

这语

to 4

$3 \overline{0}$

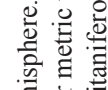

突

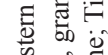

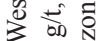

送

点

总 递宫:

舜芝至

.

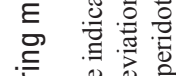

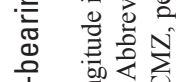

농 흐리

ฮั

ब

응 空范

힌 氙芯䍃

点

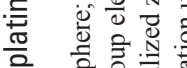

듬

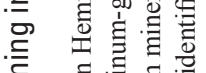

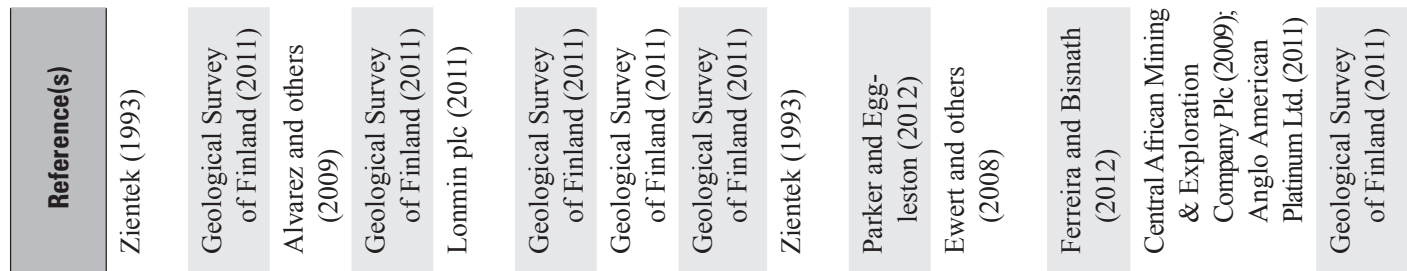

है

岩 즘

$\sin$

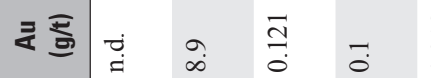

ते

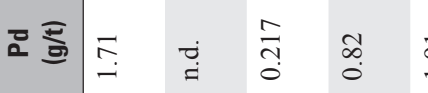

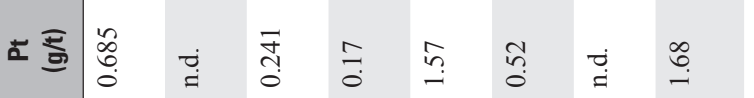

उ

$\stackrel{\infty}{\circ} \quad \check{0} \quad \frac{0}{0}$

ก)

$\stackrel{\infty}{n}$

$\frac{8}{2}$

此咅

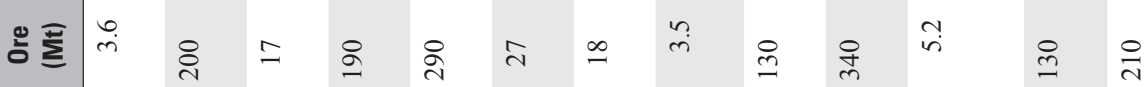

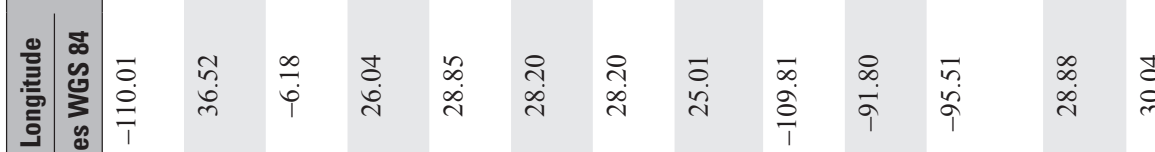

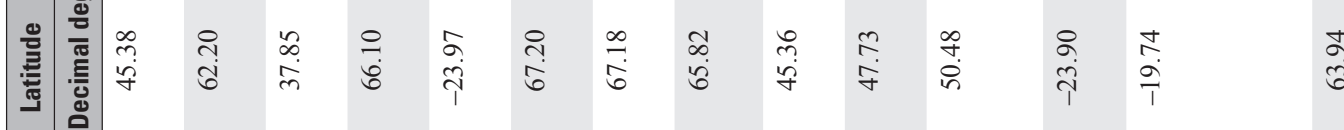

焉

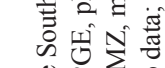

응

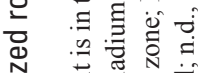

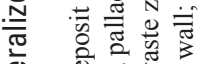

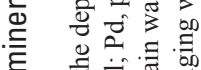

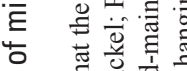

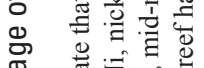

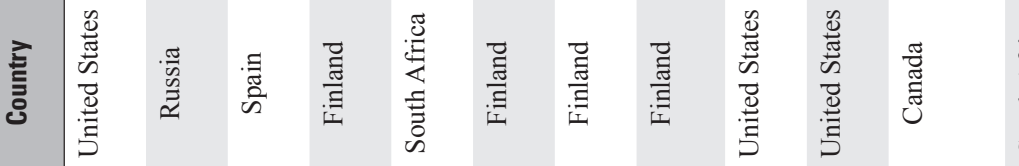

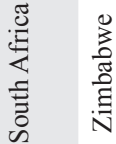

$\stackrel{\check{J}}{\sharp}$

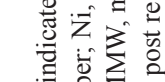

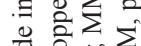

들 总额出

吾苛

๘

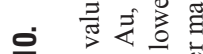

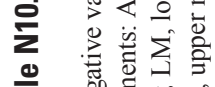

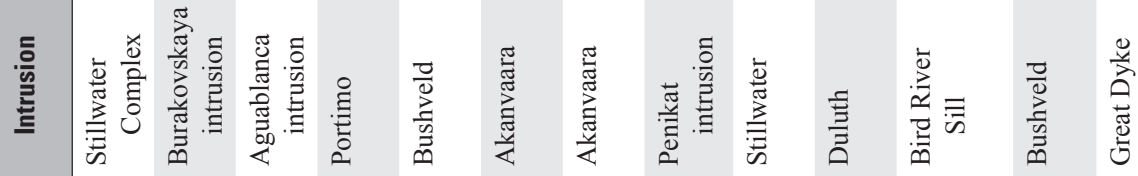

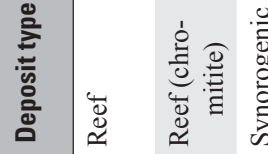

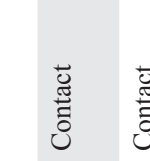

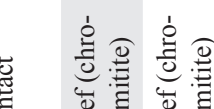

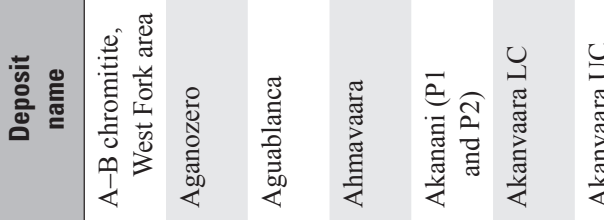

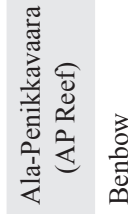

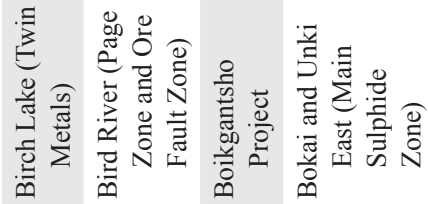

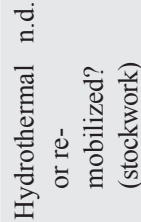




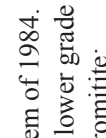

密啳

की

过 응

농

政

की

言

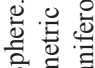

焉

을

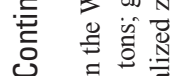

广 0

果 荡

品

웡 올

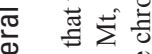

它 总

E

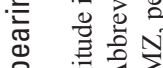

宅

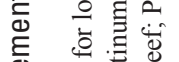

ब。

官

흥 商零

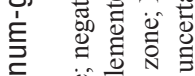

言

글

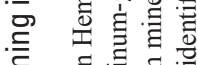

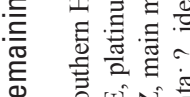

試热

능

을

总

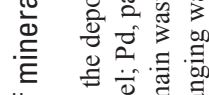

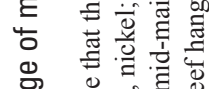

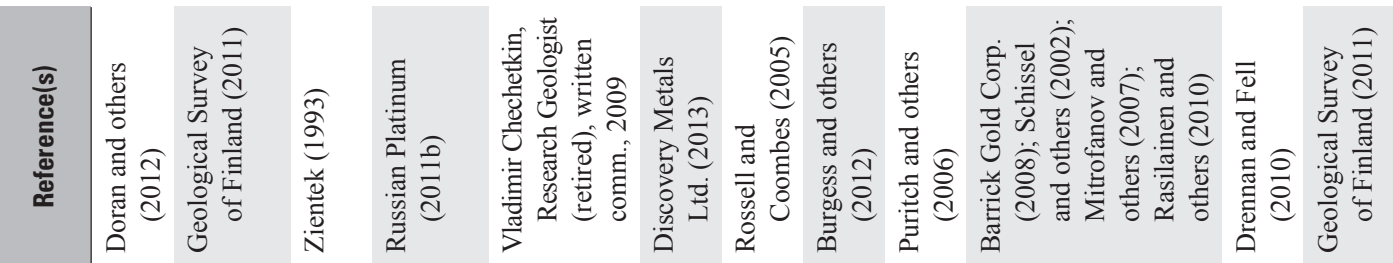

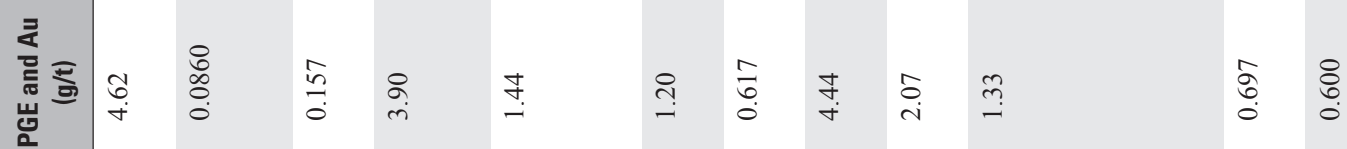

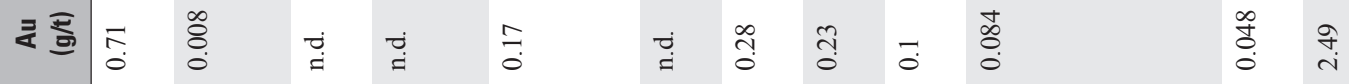

도롤

픔

घु

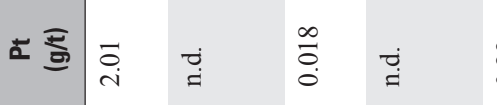

च

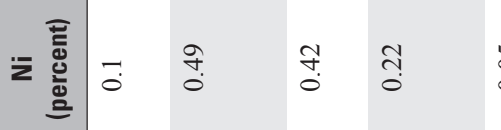

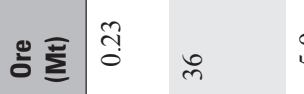

is

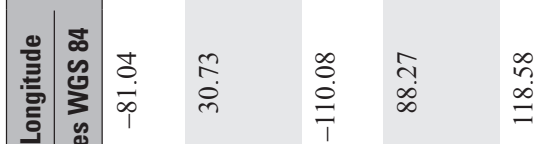

ग. व.

ت্ট்

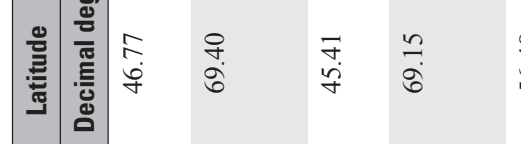

文

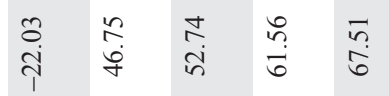

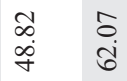

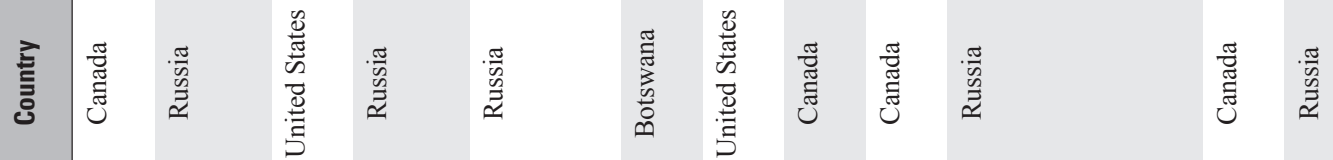

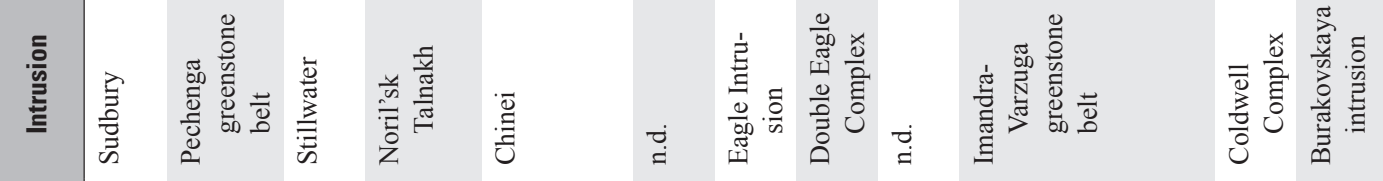

芠

을

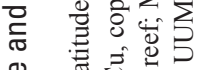

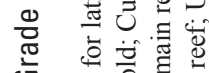

○)

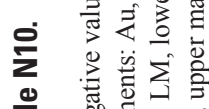

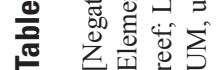

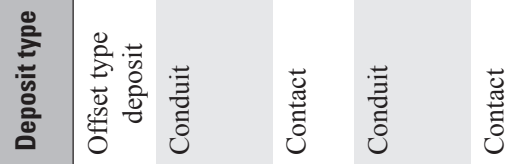

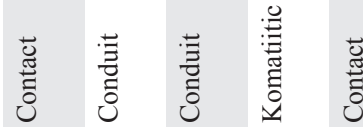

芯

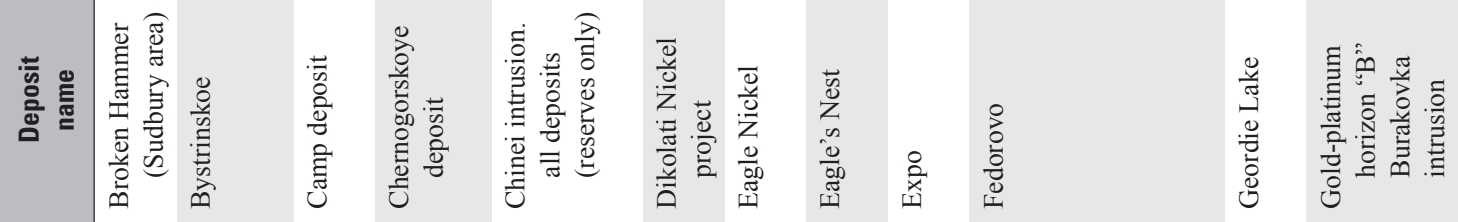




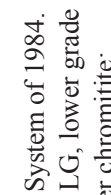

跣产

论

뫃

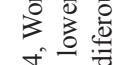

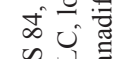

论

(

(0.0.

产

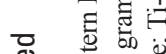

岂

突

它

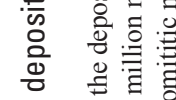

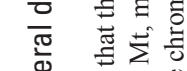

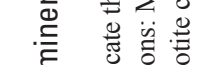

E$$
\text { (1) }
$$

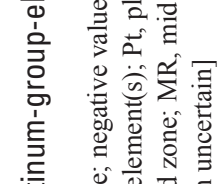

喜

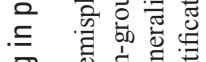

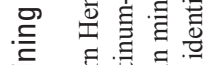

㩆影

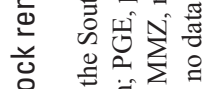

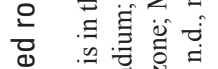

总

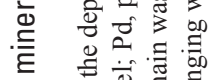

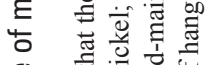

㟢

壱

흔

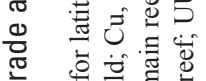

0 o

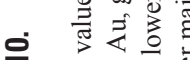

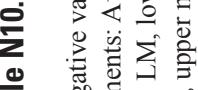

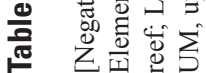

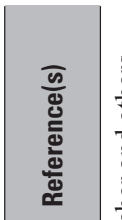

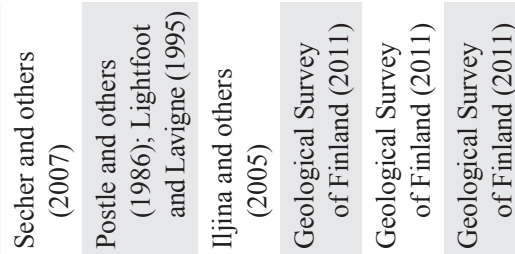

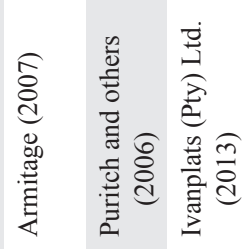

这

루ㄹㅗㅡㅇ

동 픙

ì

:

范

$\stackrel{8}{\circ}$

응

.

:

$\stackrel{0}{\frac{1}{0}}$

?

호등

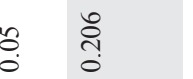

च

$z \underline{\bar{E}}$

$\stackrel{\infty}{0}$

홀

ำ

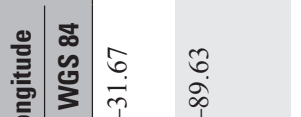

吾

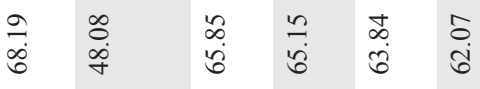

咅

픈

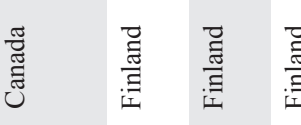

흠

荧

音

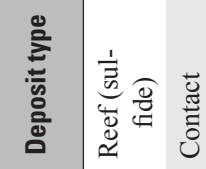

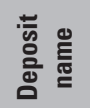

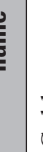

造可
苯

\section{苟}

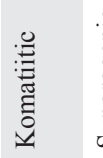

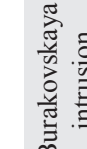

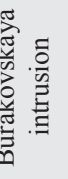

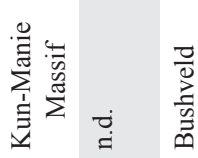

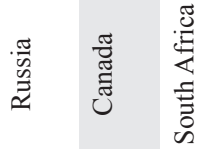

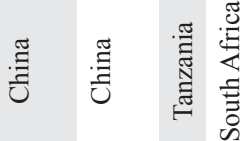

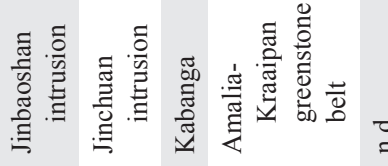

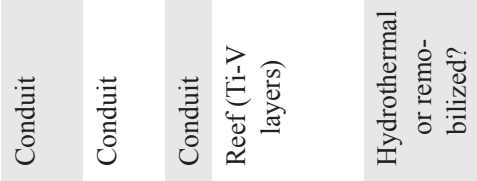

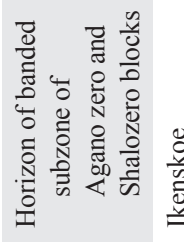

לे⿺

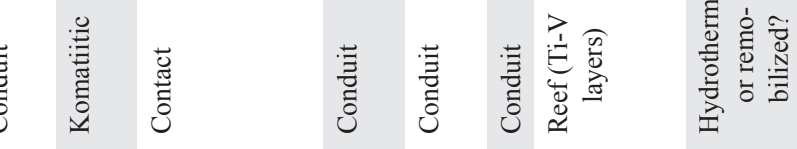

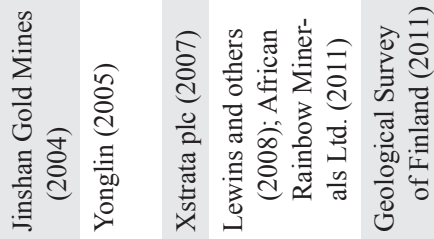

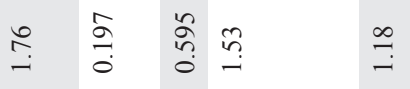

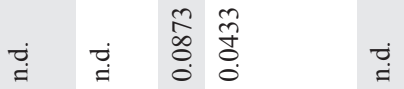

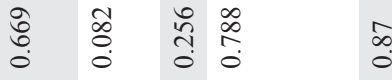

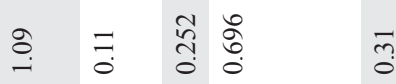

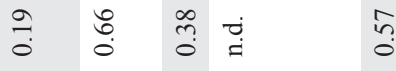

$\stackrel{\infty}{0}-\stackrel{i}{i} \stackrel{\ddot{j}}{=}$

$=$ d

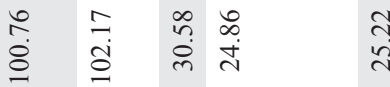

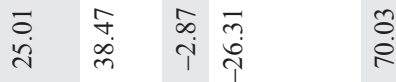

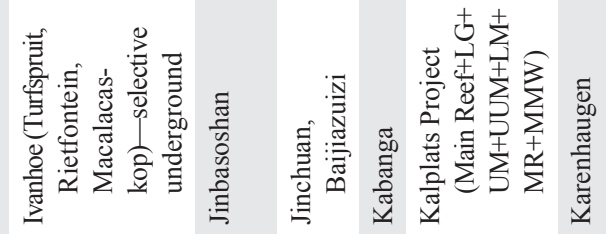




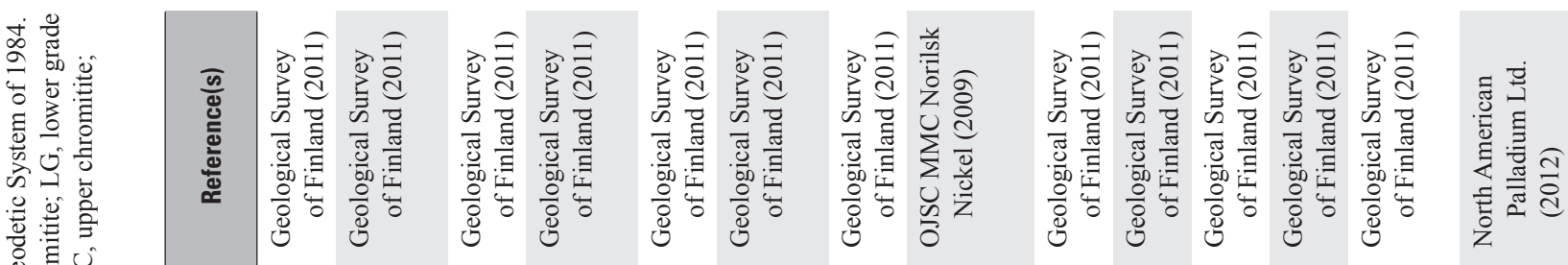

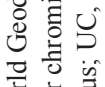

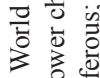

क

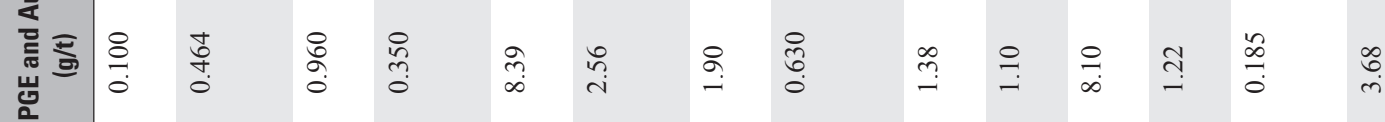

है है

这.

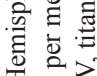

-

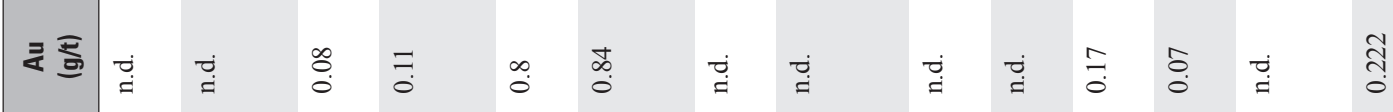

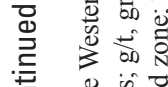

突

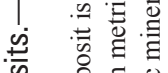

究

造

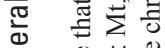

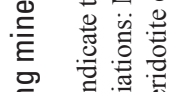

을

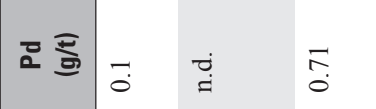

总

는

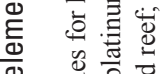

空

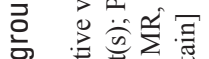

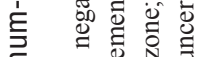

告

흘

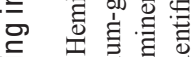

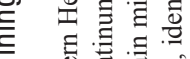

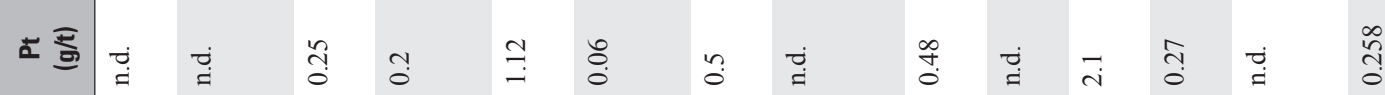

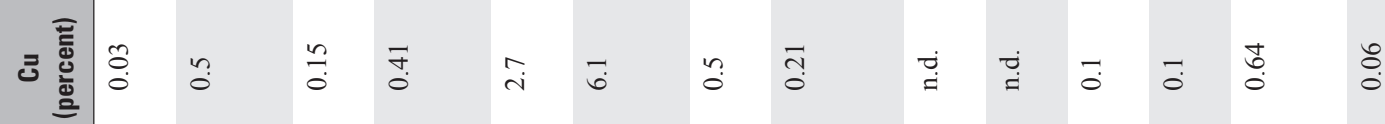

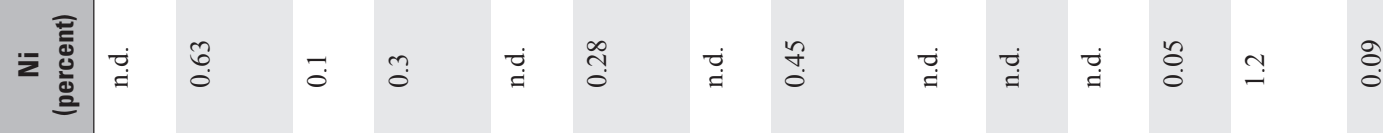

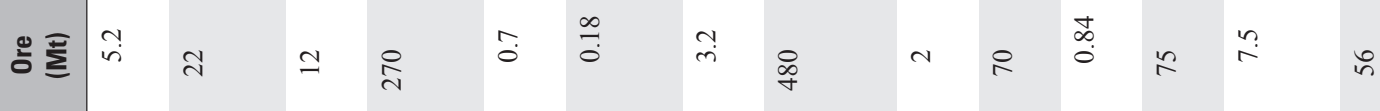

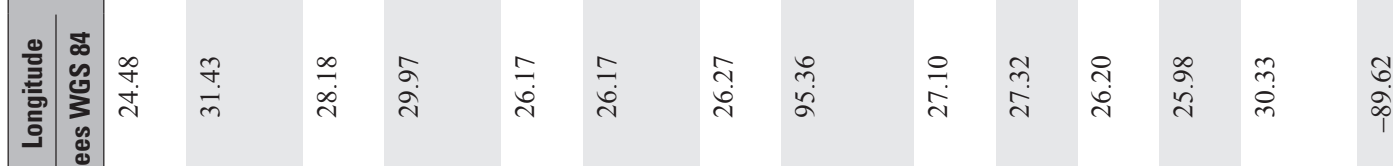

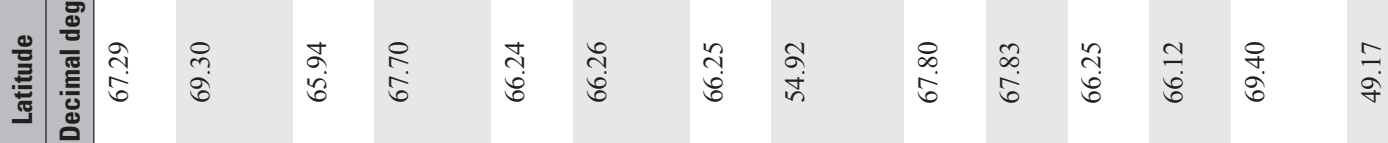

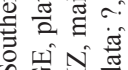

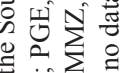

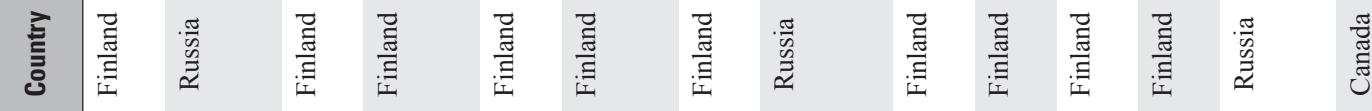

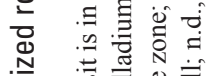

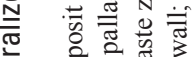

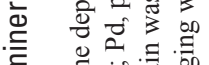

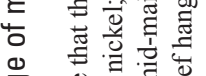

要

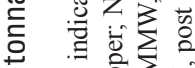

을

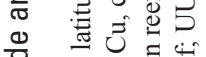

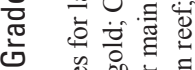

.

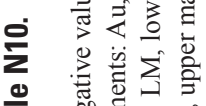

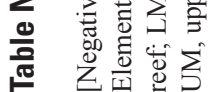

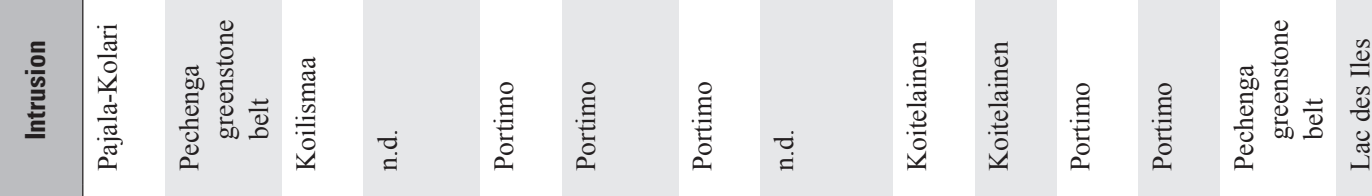

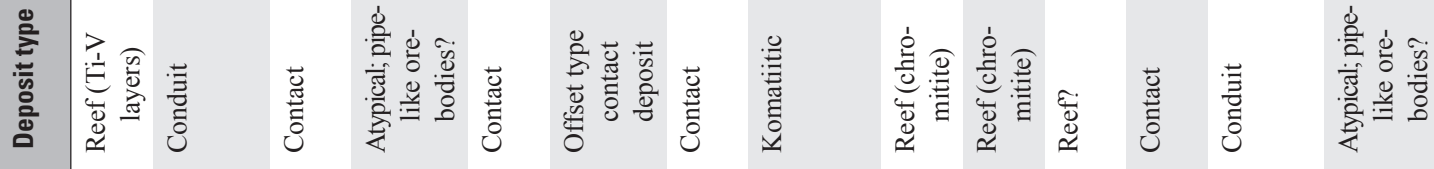

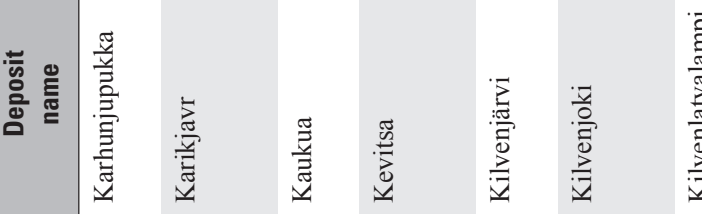

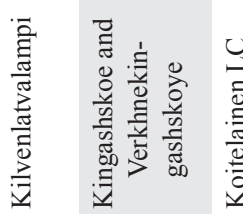
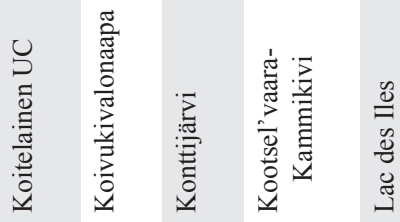


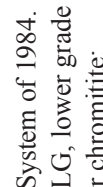

结帝

웡

究产

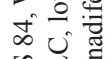

记

穿.

豙要

总

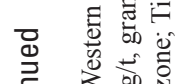

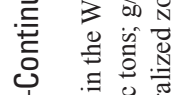

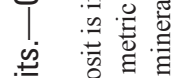

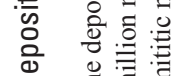

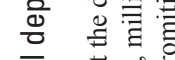

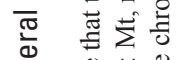

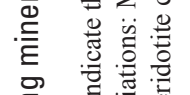

竞

要

志部方

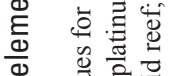

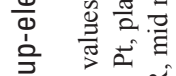

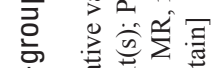

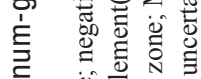

喜

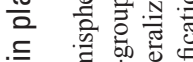

蛋 害音

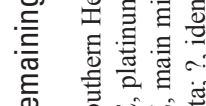

焉

응

농

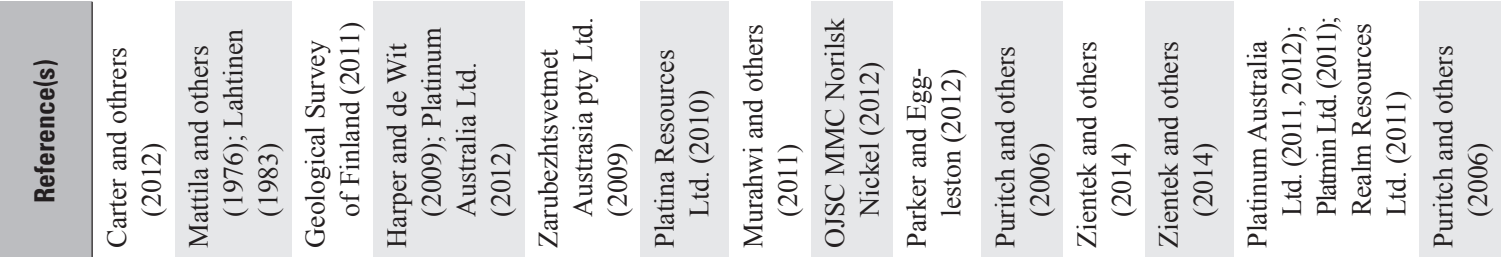

亲

㔻

इ

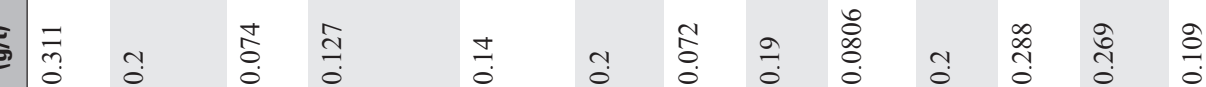

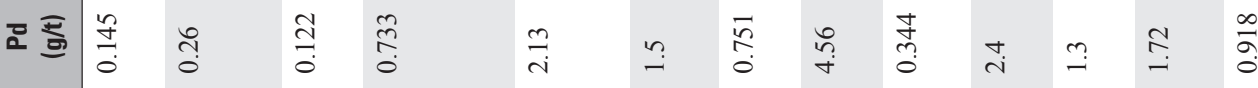

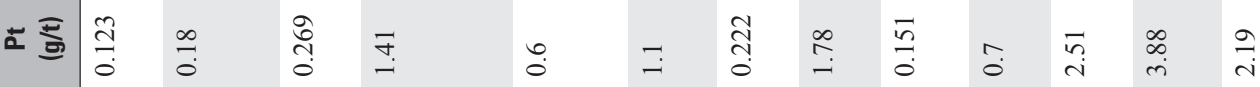

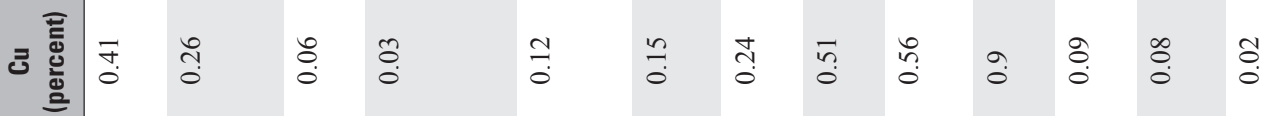

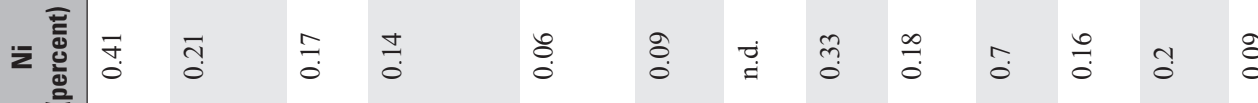

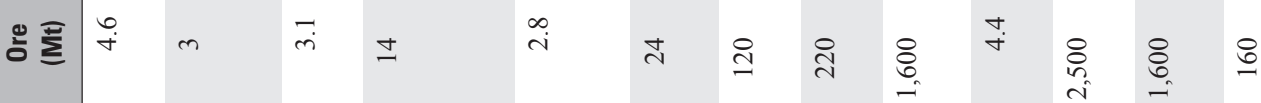

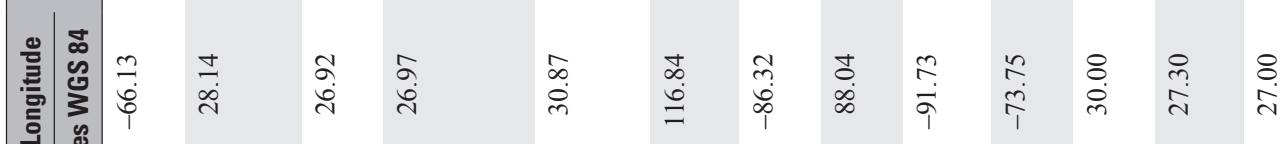

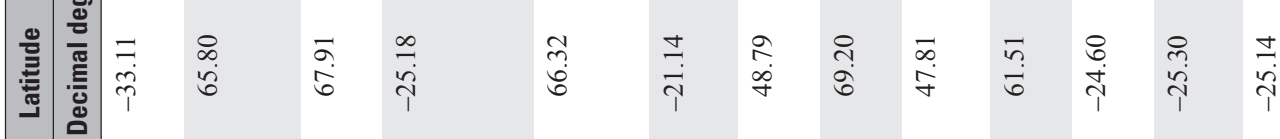

$\stackrel{\infty}{\stackrel{\infty}{6}}$

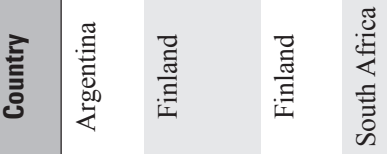

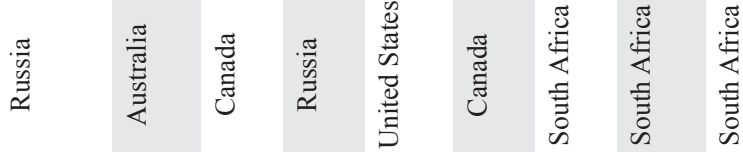

$\stackrel{\infty}{\circ}$

需

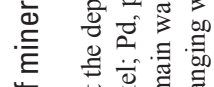

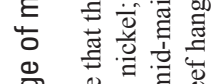

बै

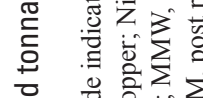

흘 을

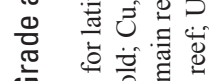

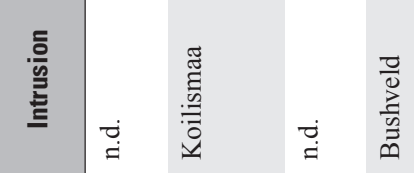

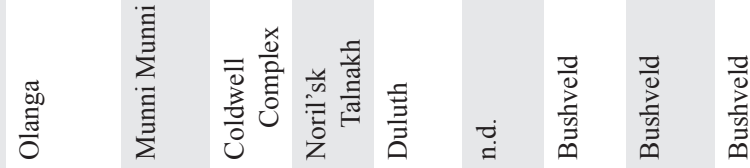

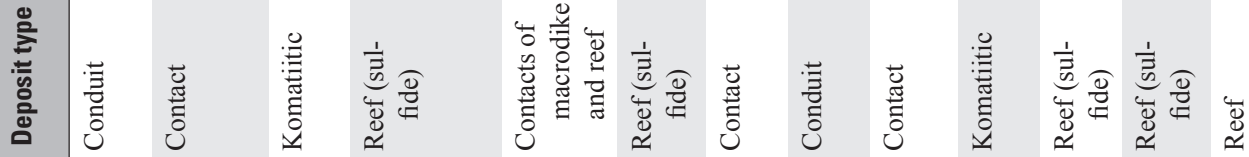

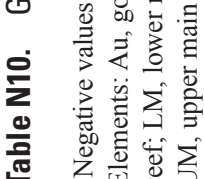

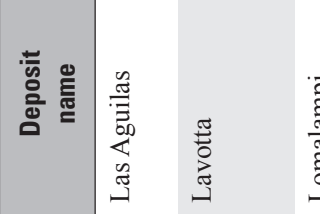

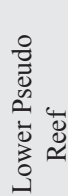
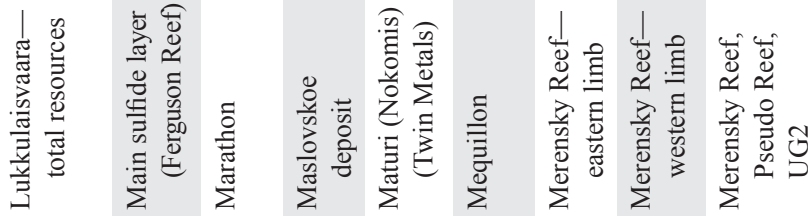


\section{进䒼 \\ 它害 \\ 空完}

की

ن

흫 㐘

范离

क्ष

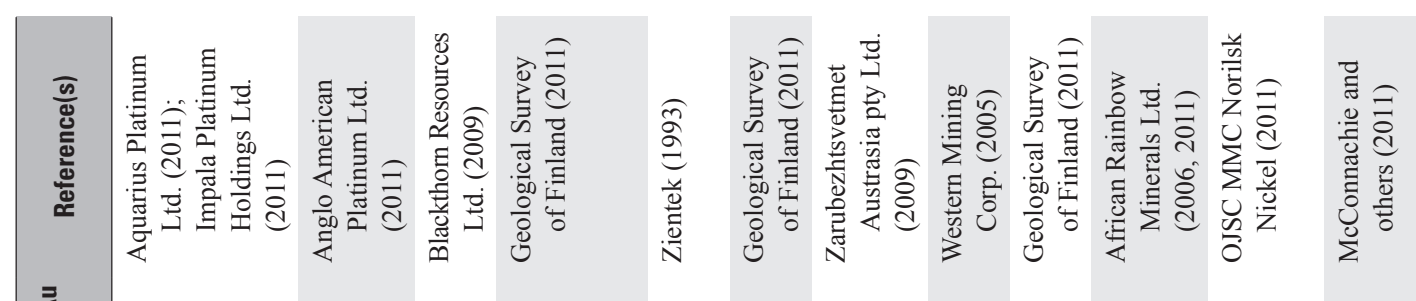

言总

एँ

की

记

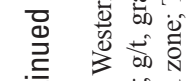

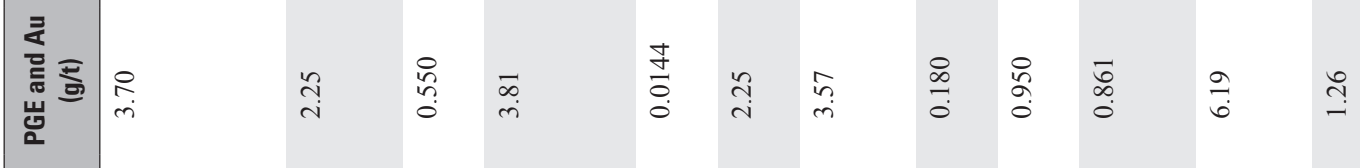

룰츠 항

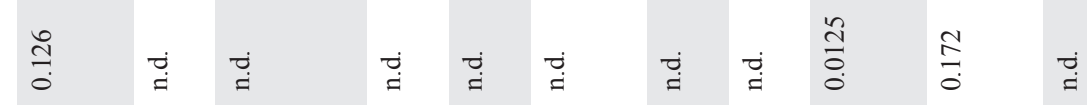

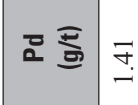

$\because$ กิ

突

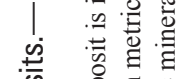

के

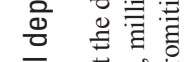

要焉芒总

产

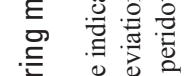

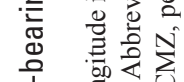

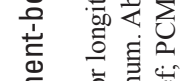

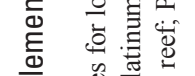

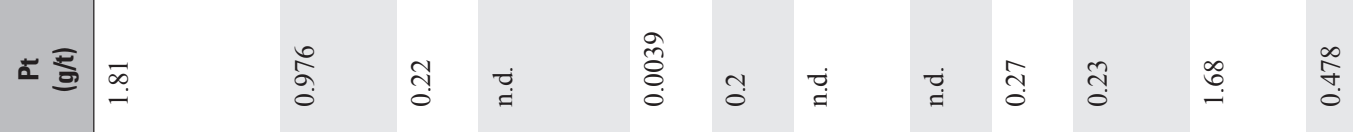

ت己

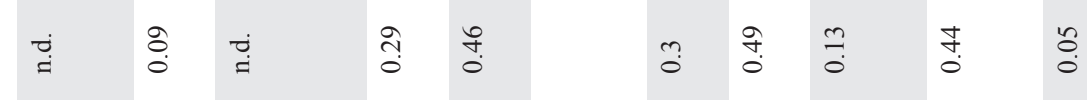

这 咅

ت্

홀

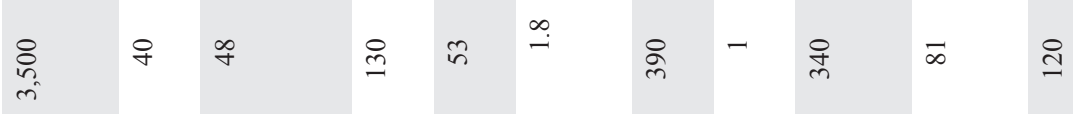

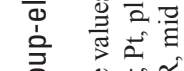

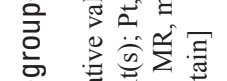

क人

竞

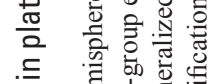

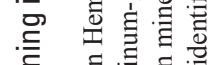

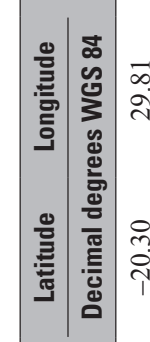

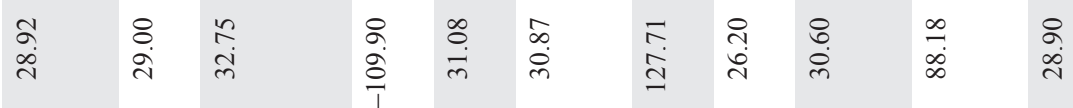

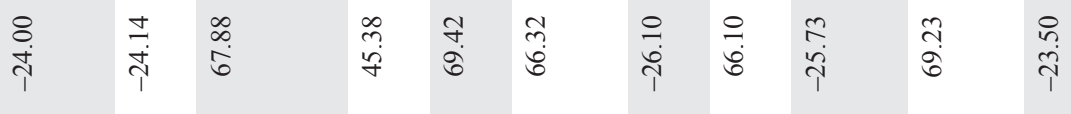

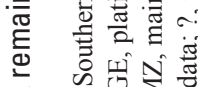

능

至

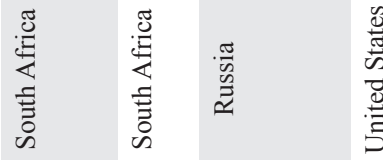

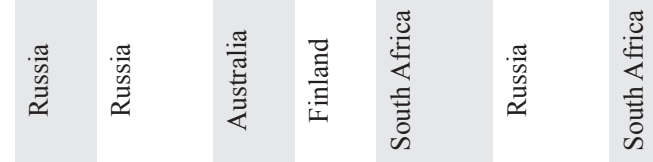

몰.

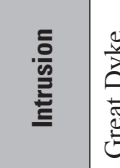

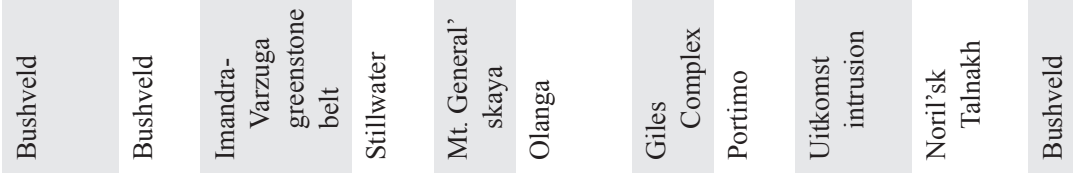

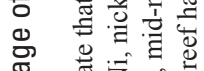

产

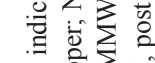

웡 $\sum_{0}$

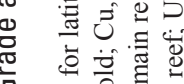

○)

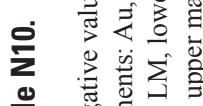

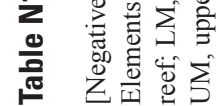

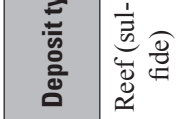

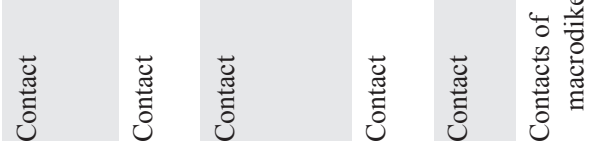

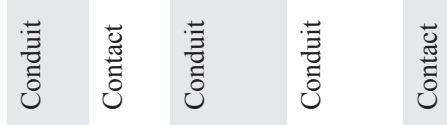

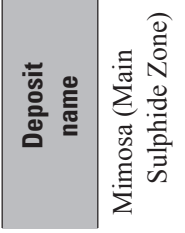

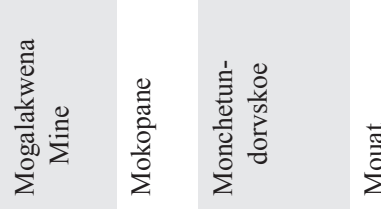

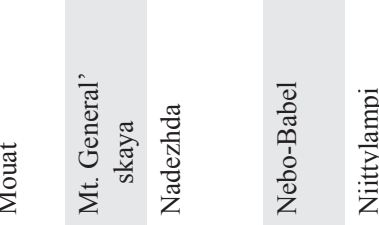

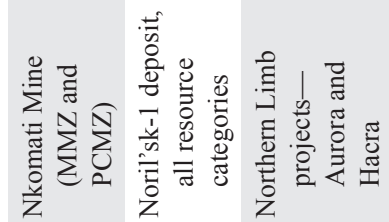



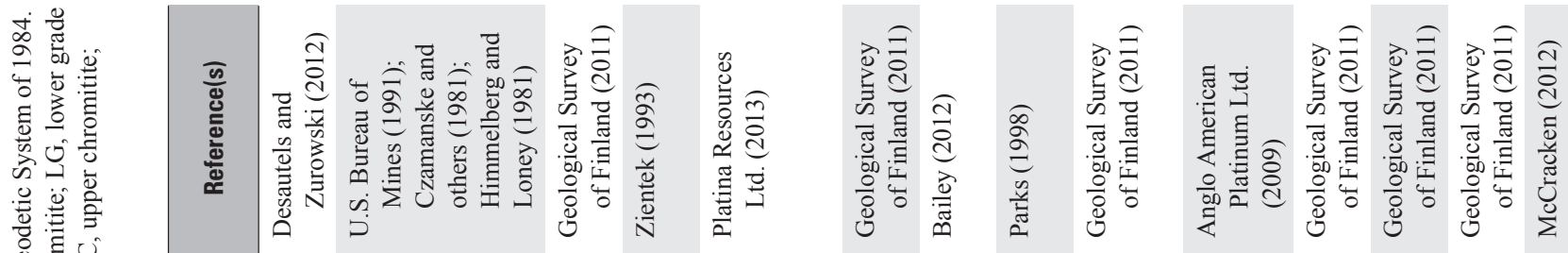

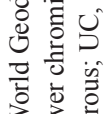

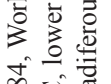

ᄅ

รั

$\stackrel{2}{\circ} \stackrel{8}{\circ}$

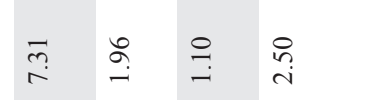

त)

प⿺⿻一⿰冫⿰亅⿱丿丶丶⿱⿰㇒一乂

3.

월

루ㄹㅗㅡ 항

$\stackrel{\square}{\circ} \stackrel{\dot{\pi}}{=}$

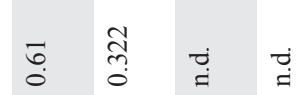

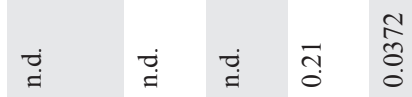

3

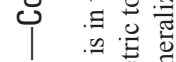

空

कo 응

응

동틈

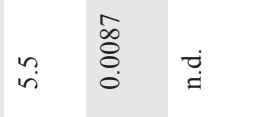

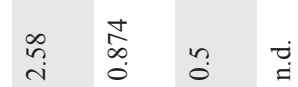

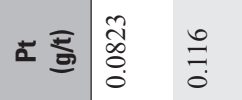

?

$\stackrel{i}{\dot{t}}$

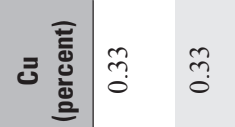

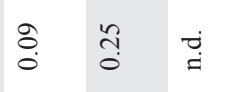

$\stackrel{\infty}{0}$

吾芝戛

.

ह

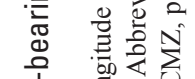

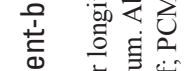

离 劳

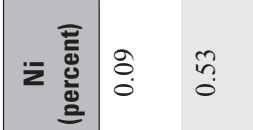

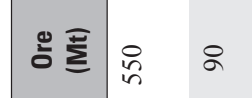

تृ

تே

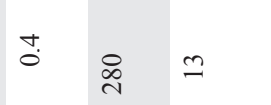

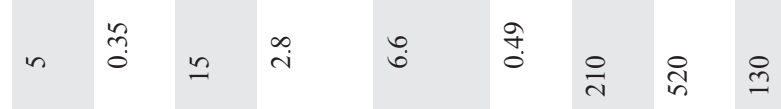

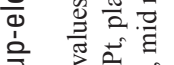

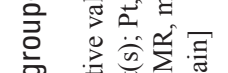

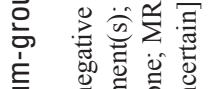

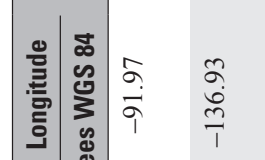

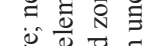

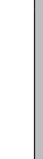

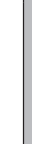

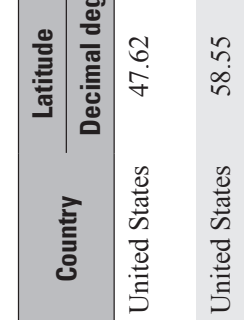

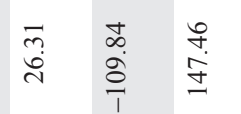

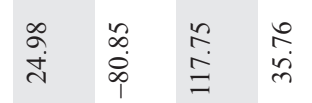

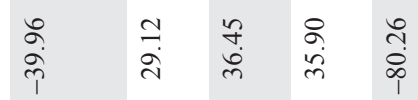

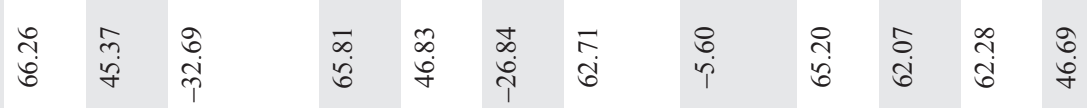

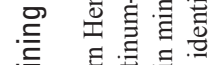

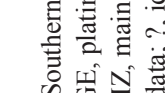

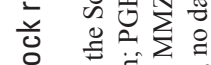

을

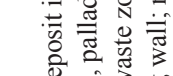

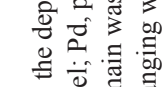

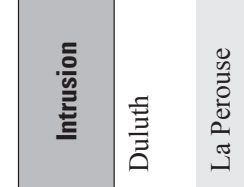

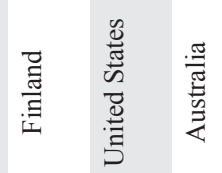

li 1

IIIH,

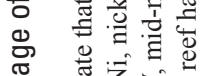

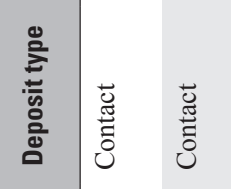

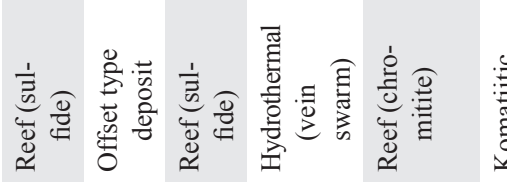

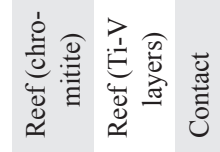

๙

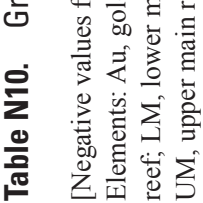

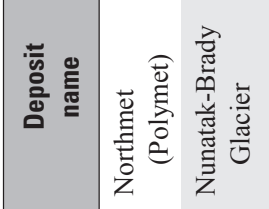

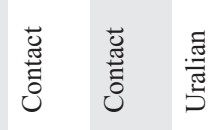

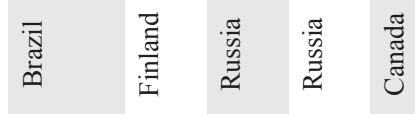

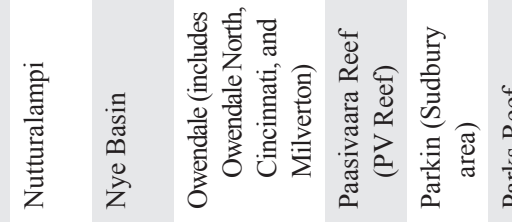

!

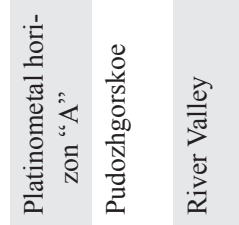




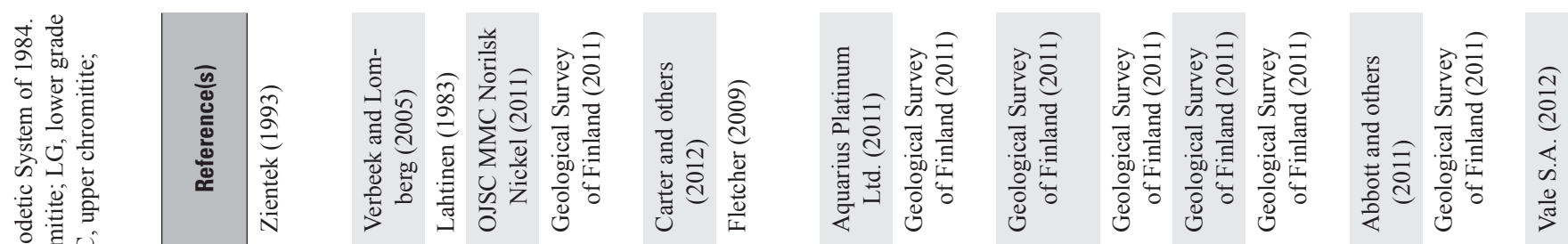

过 흥

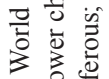

年,

范

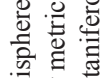

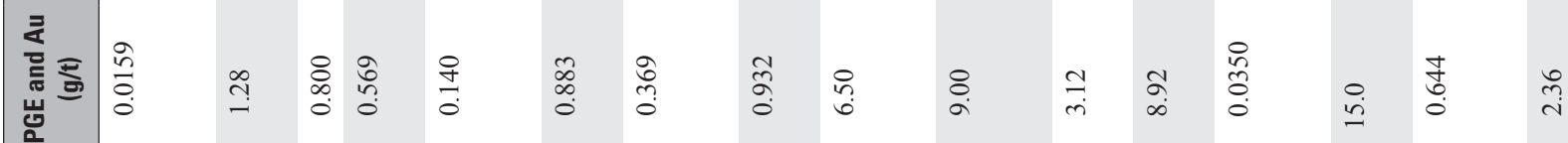

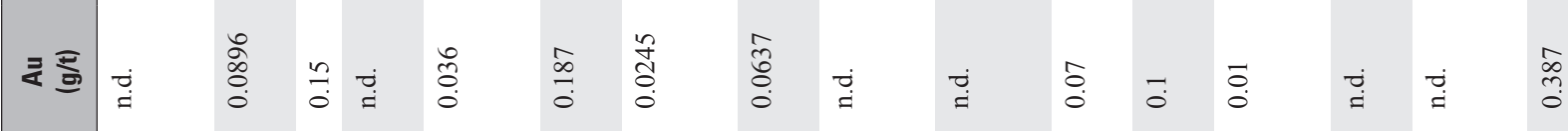

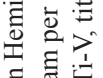

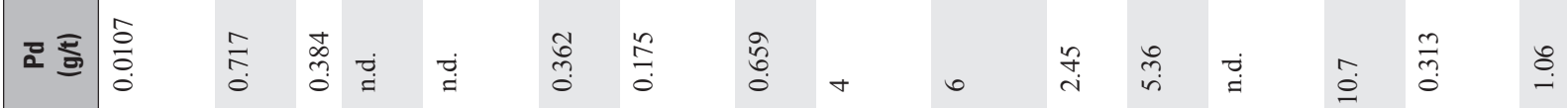

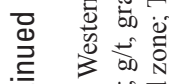

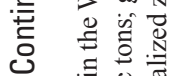

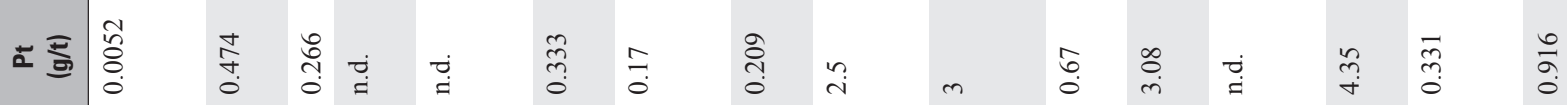

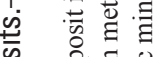

के 흥 흥

造 号夆

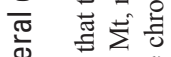

亭

을

要

흘

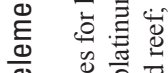

产

흘

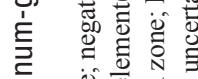

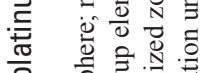

들

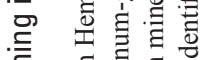

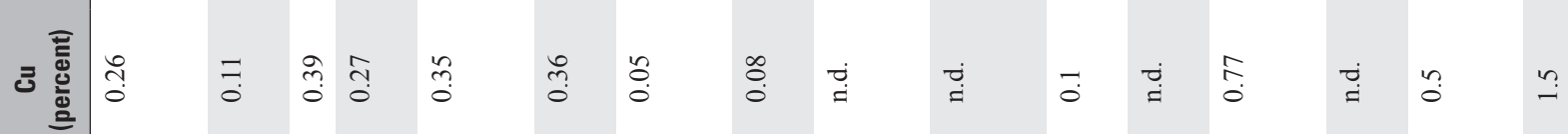

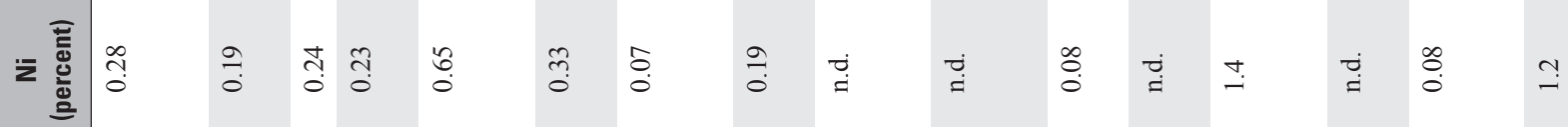

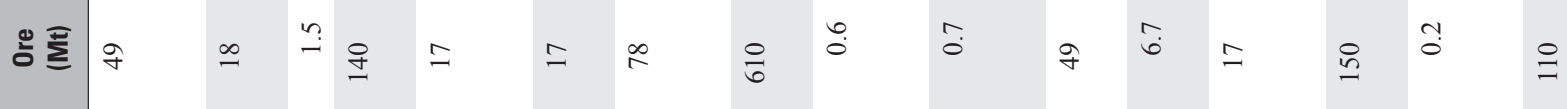

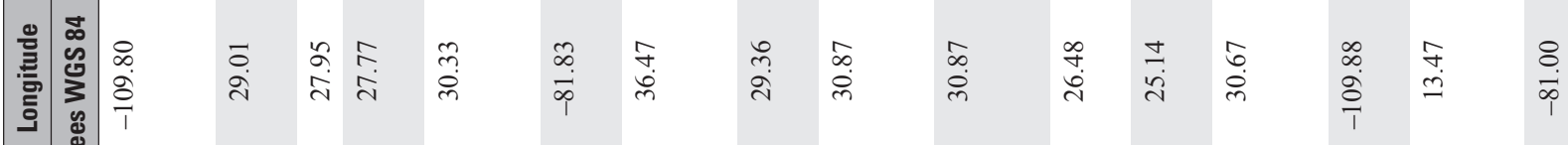

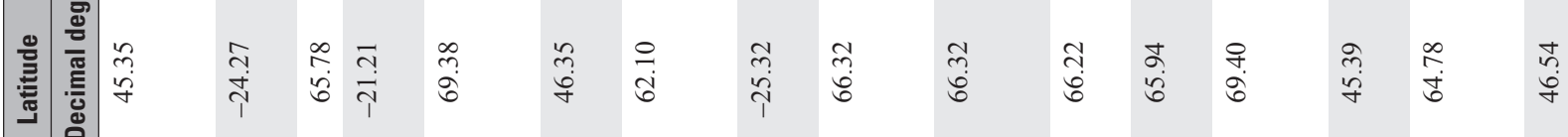

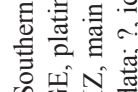

능

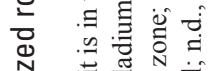

券

要

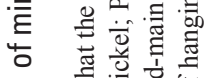

ه

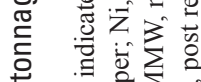

을

元

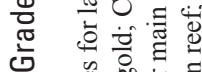

0 论

运

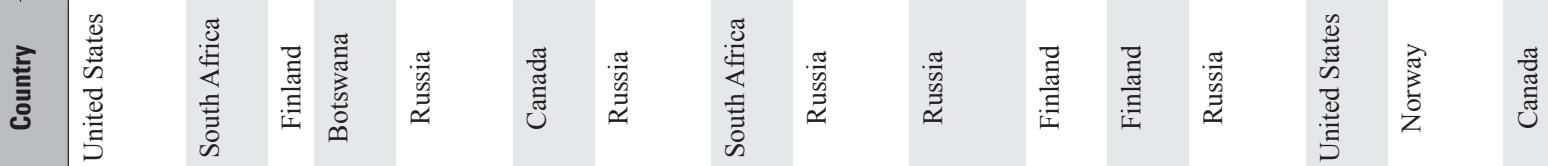

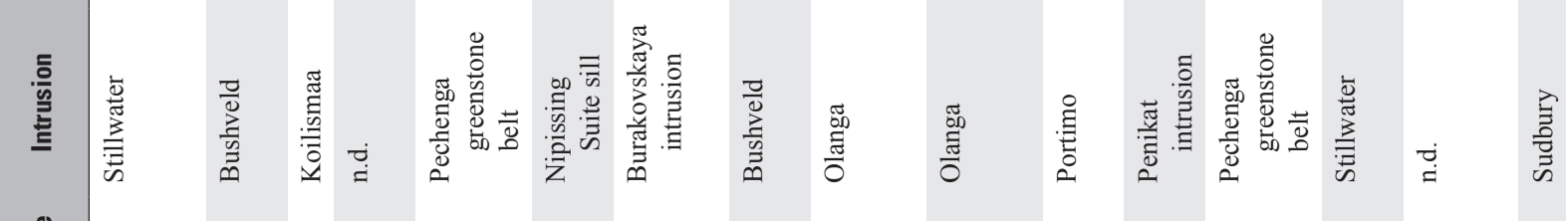

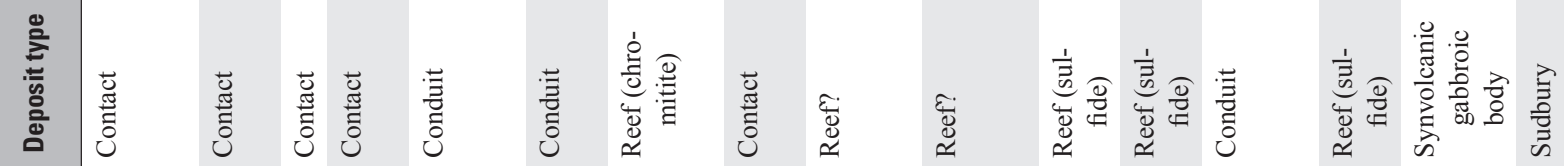

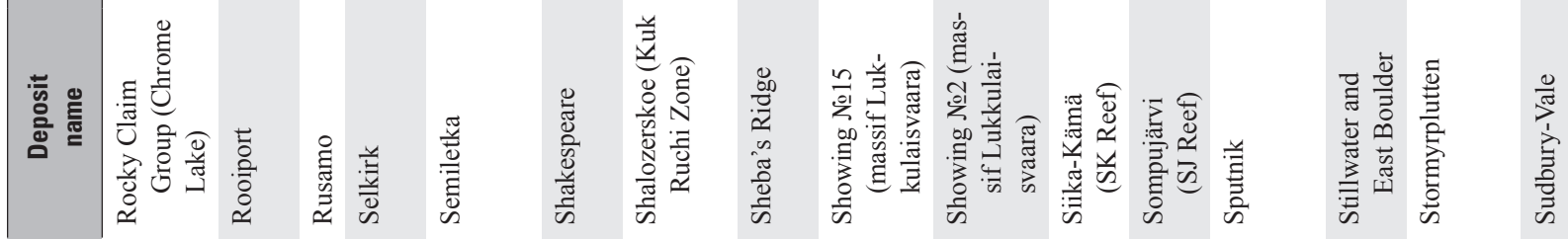




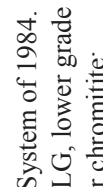

记

要焉

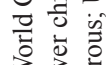

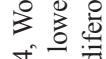

倍

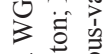

密. ․ㅠㄹ

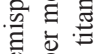

焉是

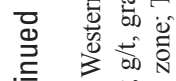

言 至产

它喓要

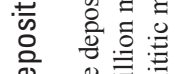

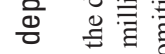

画 焉芝帝

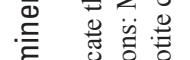

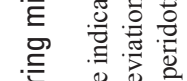

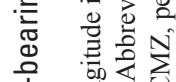

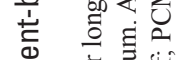

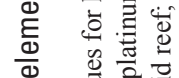

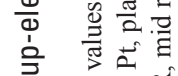

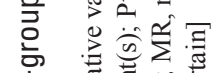

䒠

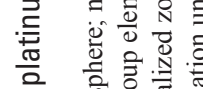

흠

总

㖣

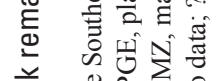

히일

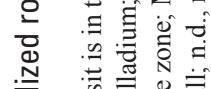

总

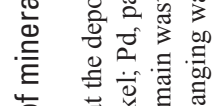

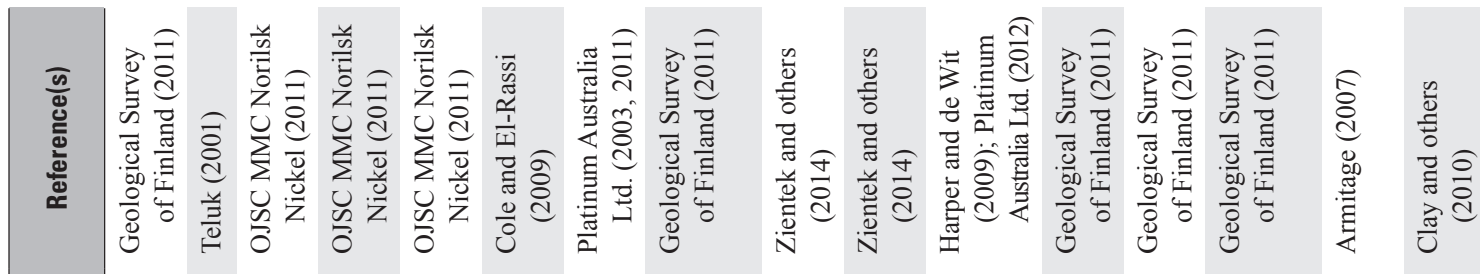

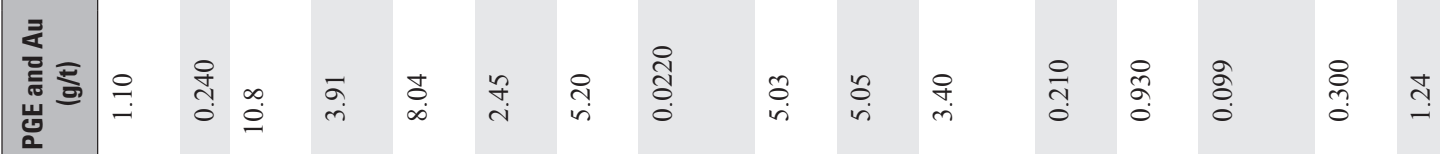

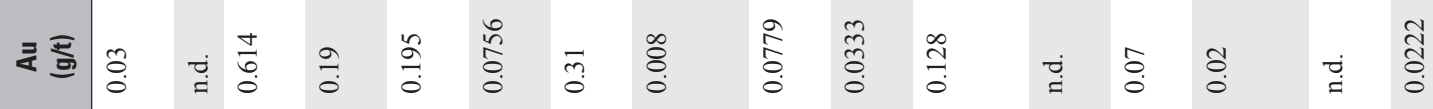

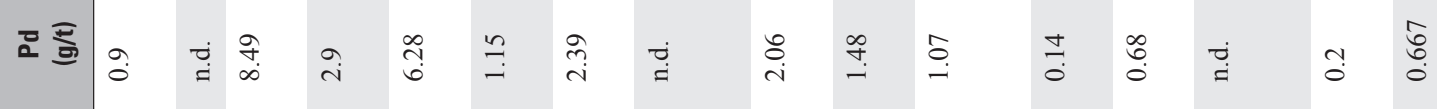

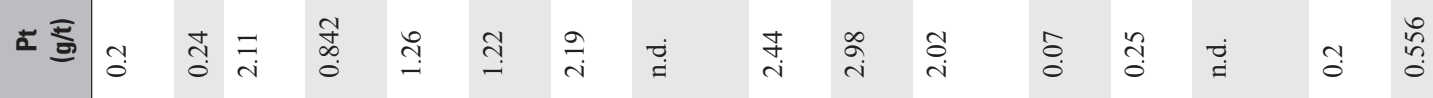

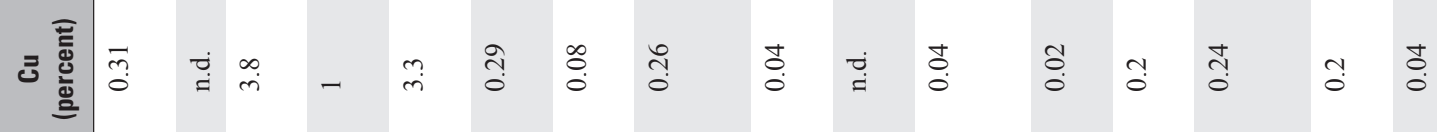

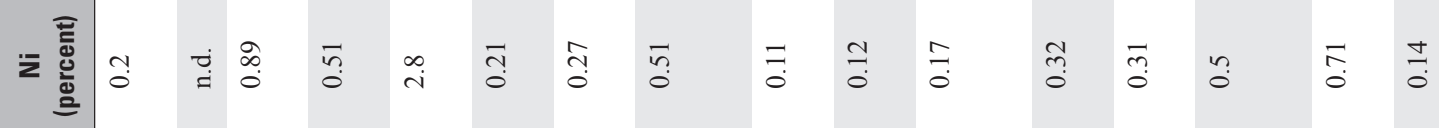

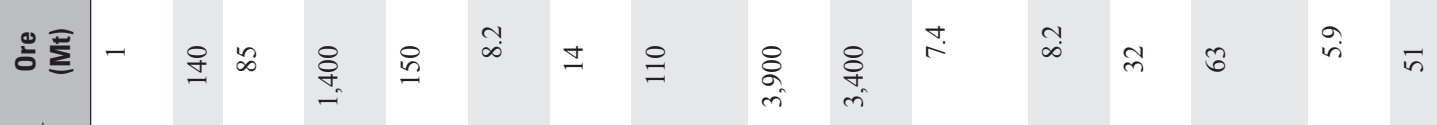

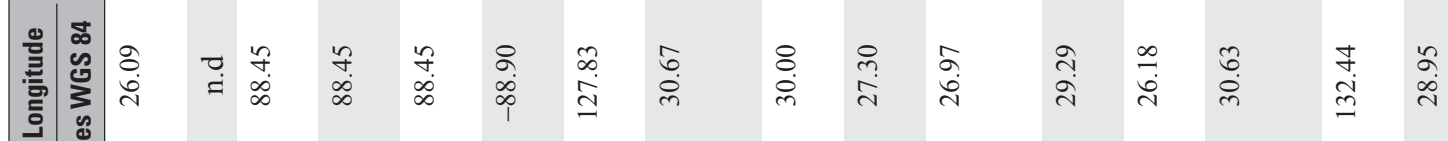

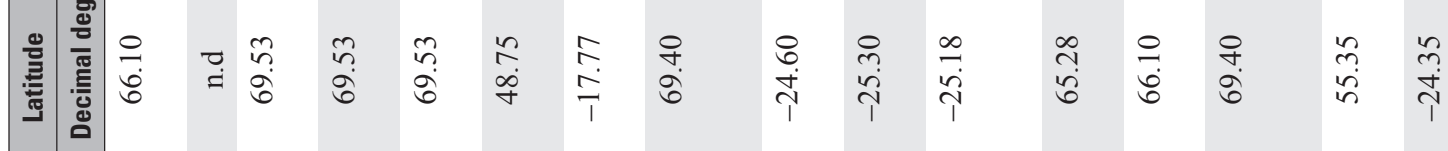

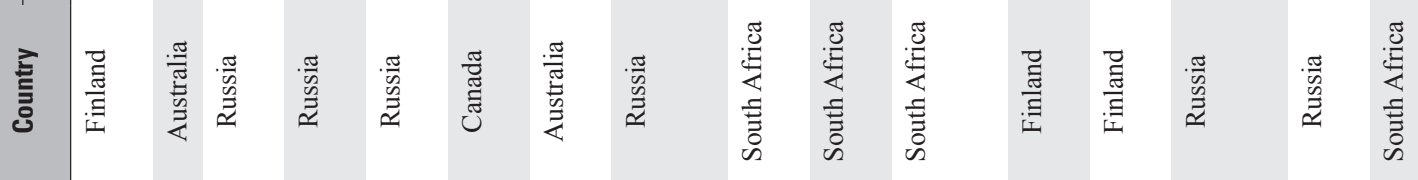

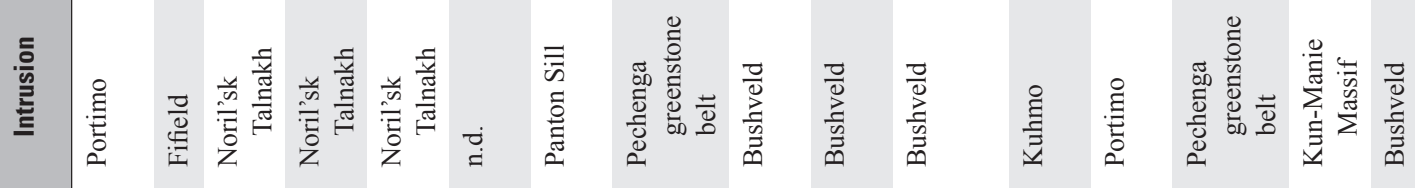

要

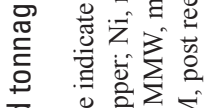

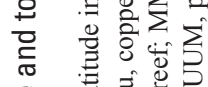

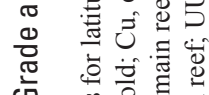

过

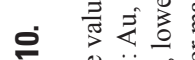

$\sum_{0}$

产

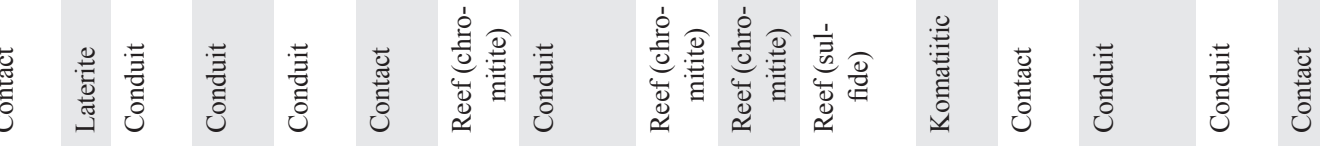

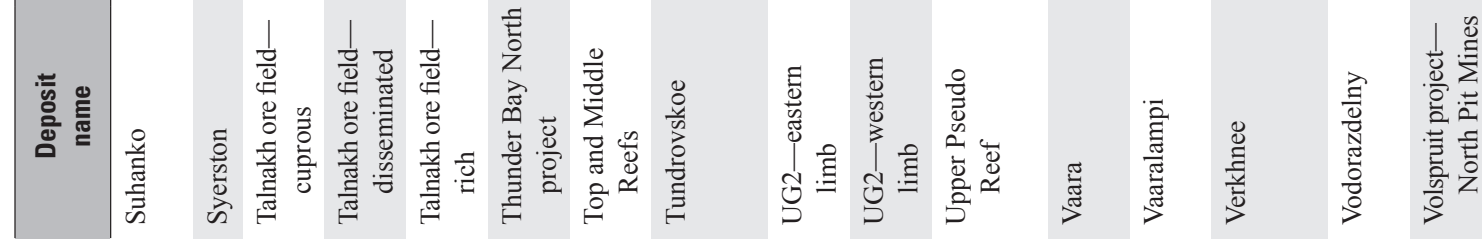




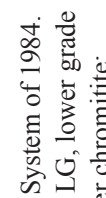

约

过

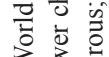

政

U.

落

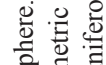

急要

- 廌

尝

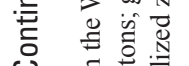

1.0

劳

离

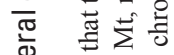

喜

ह

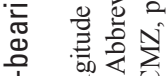

흘

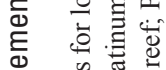

产 总

言

눈

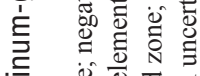

言

흘

돌

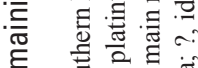

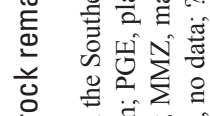

을

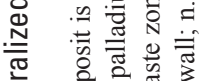

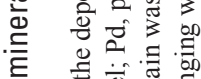

등

。

兽

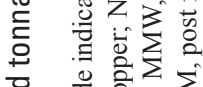

흘

悹

o

을

章

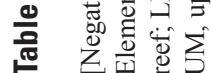

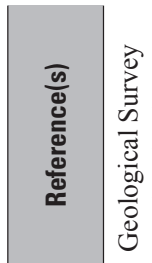

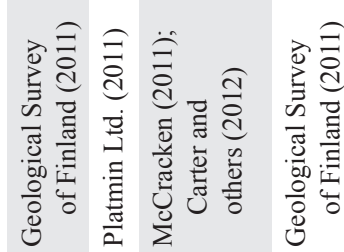

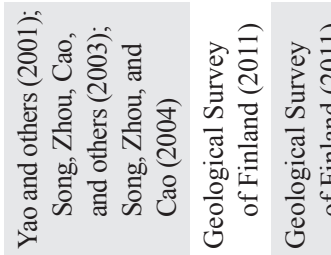

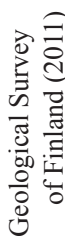

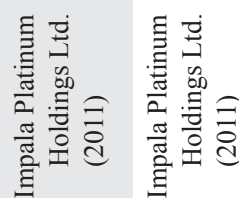

焉

루음

$\underset{m}{\dot{m}} \exists \frac{m}{\sigma}$

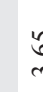

ถู่

각

$\stackrel{8}{\circ}$

$\stackrel{8}{+} \quad \stackrel{n}{m}$

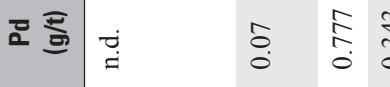

동

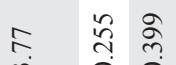

c)

$\stackrel{\ddot{घ}}{\ddot{=}}$

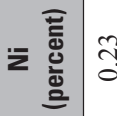

घं

올

กี่

童离

密

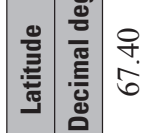

กิ่

$\stackrel{n}{?}$

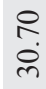

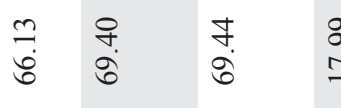

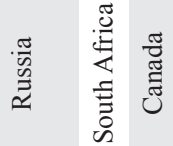

$\frac{1}{2}$

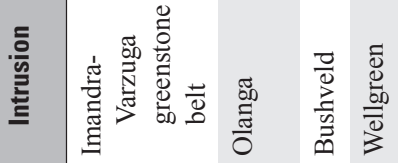

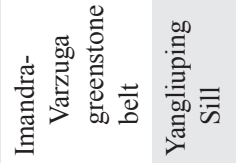

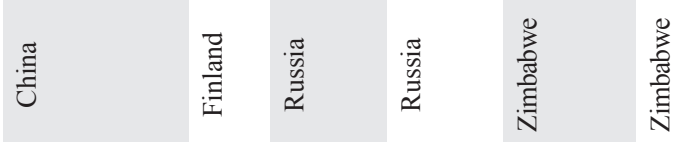

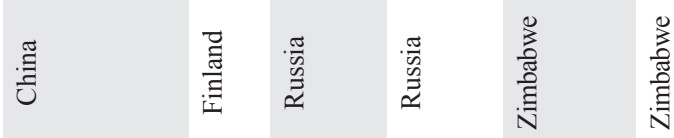

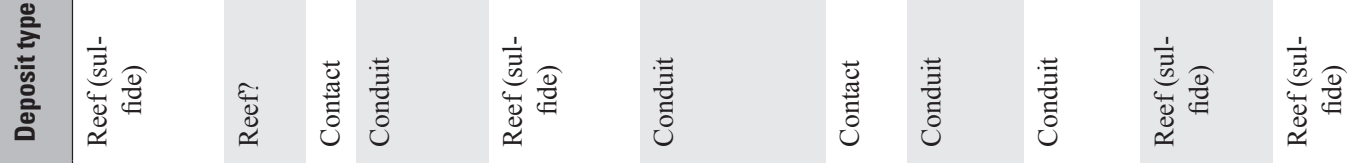

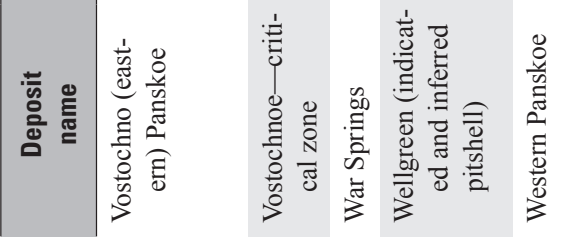

率

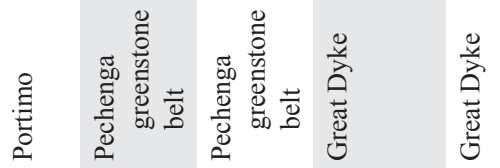



For more information concerning this report, please contact:

Mineral Resources Program Coordinator

U.S. Geological Survey

913 National Center

Reston, VA 20192

Telephone: 703-648-6100

Fax: 703-648-6057

Email:minerals@usgs.gov

Home page: https://minerals.usgs.gov

Prepared by the USGS Science Publishing Network Reston Publishing Service Center

Edited by J.C. Ishee and Stokely J. Klasovsky Illustrations by Caryl J. Wipperfurth

Layout by Caryl J. Wipperfurth and Cathy Y. Knutson

Posting by Angela E. Hall 
